\title{
REVISIONES
}
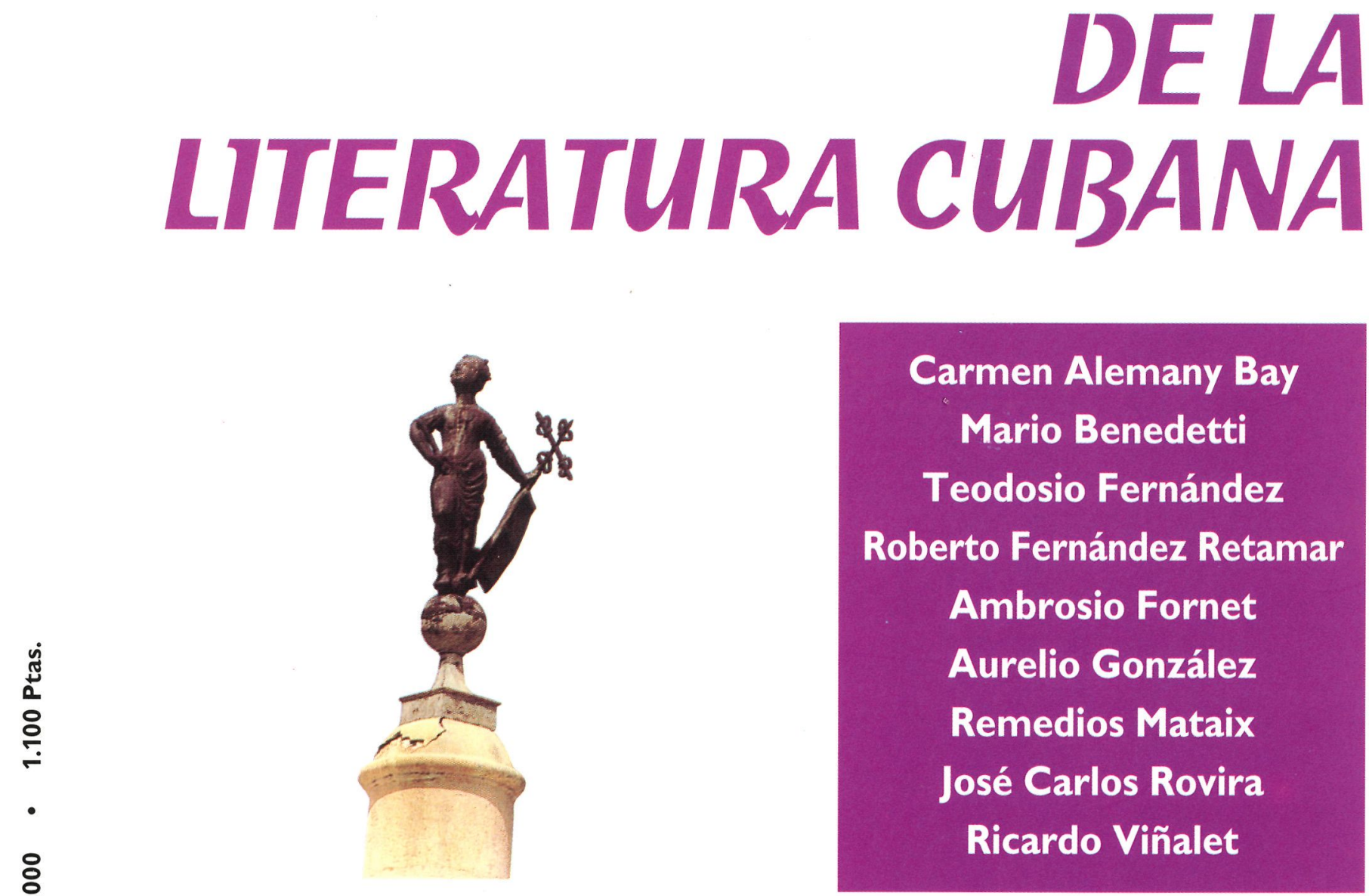

Carmen Alemany Bay

Mario Benedetti

Teodosio Fernández

Roberto Fernández Retamar

Ambrosio Fornet

Aurelio González

Remedios Mataix

José Carlos Rovira

Ricardo Viñalet

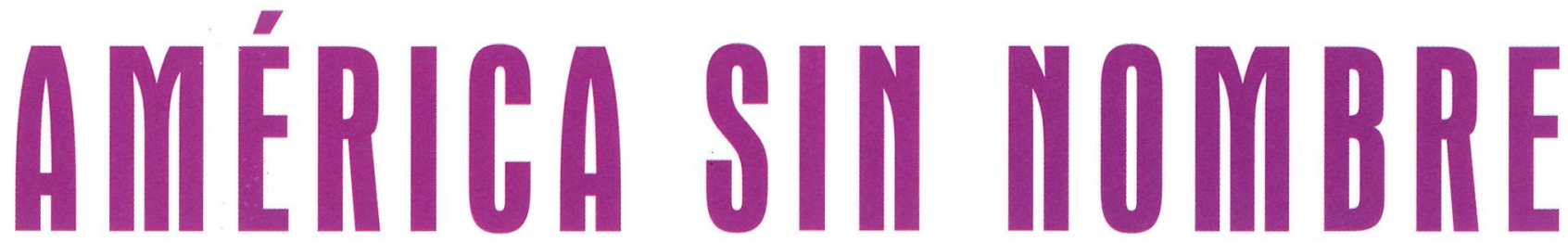

N Boletín de la Unidad de Investigación de la Universidad de Alicante: «Recuperaciones $\stackrel{\imath}{z}$ del mundo precolombino y colonial en el siglo XX Hispanoamericano» 
AMÉRICA SIN NOMBRE es el Boletín de la Unidad de Investigación de la Universidad de Alicante «Recuperaciones del mundo precolombino y colonial en el siglo XX Hispanoamericano» (Proyecto MEC PB 980982) y tendrá una periocidad de un número anual. En este número se reproducen las intervenciones en el Curso de Literatura Cubana realizado entre el 1 y el 10 de julio de 1988 .

ESTE NÚMERO está financiado parcialmente por la Consellería de Educación de la Generalitat Valenciana, Dirección General de Investigación Universitaria, dentro de su programa de Congresos (ORG98-09-23) de 2000.

Director: José Carlos Rovira

Subdirectora: Carmen Alemany Bay

Secretaria: Remedios Mataix Azuar

\section{Consejo editorial:}

Beatriz Aracil Varón (UA, coordinadora)

Miguel Ángel Auladell Pérez (UA)

Eduardo Becerra Grande (Universidad Autónoma de Madrid)

Teodosio Fernández Rodríguez (Universidad

Autónoma de Madrid)

Virginia Gil Amate (Universidad de Oviedo)

Aurelio González (El Colegio de México)

Rosa María Grillo (Universidad de Salerno)

Ramón Lloréns García (UA)

María Águeda Méndez (El Colegio de México)

Francisco Javier Mora Contreras (UA)

Ramiro Muñoz Haedo (UA)

Nelson Osorio Tejeda (Universidad de Santiago de

Chile)

Ángel Luis Prieto de Paula (UA)

Francisco Tovar Blanco (Universitat de Lleida-

Estudi General)

\section{Colaboradores:}

Claudia Comes Peña

Mónica García Irles

David García Vergara

Pedro Mendiola Oñate

Francisco Mollá Ruiz

Elena Pellús Pérez

Rafael Sellers Espasa

Eva Valero Juan

Paola Madrid Moctezuma

Este boletín está asociado a la actividad del CENTRO DE ESTUDIOS IBEROAMERICANOS «MARIO BENEDET"TI»

ISSN: $1577-3442$

Depósito Legal: MU-2335-1999

\section{AMÉRICA SIII IOMBRBE}

Boletín de la Unidad de Investigación de la Universidad de Alicante: «Recuperaciones del mundo precolombino y colonial en el siglo XX Hispanoamericano»

$\mathrm{N}^{\circ}$ 2, diciembre de 2000

1.100 pesetas 


\section{AMÉRICA SIII HOMBPBE \\ sumario}

José Carlos Rovira $3 \quad$ Editorial: Revisiones de la literatura cubana

Roberto Fernández Retamar 5 Introducción a la literatura cubana

José Carlos Rovira y 16 José Lezama Lima y la fundación imaginaria de la Remedios Mataix literatura colonial cubana

Aurelio González $24 \quad$ El romancero en América y la tradición cubana

José Carlos Rovira $35 \quad$ Siglo XVII: ecos de la épica y la arcadia italiana en Cuba: Espejo de paciencia de Silvestre de Balboa

Ricardo Viñalet 43 De cómo Fernando Ortiz supo hallar una moza esquiva para cierto caballero encantado

Ambrosio Fornet $56 \quad$ En la encrucijada del fin de siglo

Mario Benedetti 62 Poesía cubana del siglo XX: un vistazo personal y selectivo

Remedios Mataix 72 De la revolución vanguardista al estallido de la revolución. Notas sobre poesía y política entre 1930 y 1959

Teodosio Fernández 84 La narrativa cubana del siglo XX. Notas para la reconstrucción de un proceso

Carmen Alemany Bay 92 Poesía cubana a finales del XX: 1980-2000 


\section{Revisiones de la Literatura Cubana}

José Carlos Rovira

A comienzos de julio de 1998 realizamos un curso en la Universidad de Alicante dedicado a la literatura cubana. Aquel curso tenía el valor de enlazar a algunos estudiosos españoles de la misma con otros, cubanos y latinoamericanos, que fueran a dar cuenta, ordenada y cronológicamente, de espacios y propuestas varias que, junto para la formación de los estudiantes que se inscribieron, sirvieran para hacer un estado de la cuestión y plantear líneas hacia el futuro.

Convertir las notas de un curso en artículos ha demorado la aparición de este segundo número de América sin nombre, y por razones que no viene al caso explicar, ha impedido la presencia de un capítulo sobre la literatura de la negritud que es un vacío reconocido desde ahora, aunque intentaremos remediarlo en un próximo número que, coincidiendo con el centenario de Nicolás Guillén en 2002, cubra monográficamente las líneas de la tradición y de la contemporaneidad cubanas y latinoamericanas sobre este aspecto.

Otra cuestión es la amplitud del enfoque que voluntariamente asumimos en aquel curso y en la confección de la revista. En el término revisiones confluyen algunos aspectos que se ordenan cronológicamente, pero que no pretenden asumir una literatura en toda su tradición y en toda su práctica actual. Las revisiones son en este caso apuntes sobre algunos aspectos, y la entidad de sus realizadores es la única garantía de persistencia de las mismas. En los panoramas de Roberto Fernández Retamar y de Mario Benedetti encontraremos el ejemplo de lo que anunciamos: caben otros enfoques, pero estos panoramas son desde ahora visiones imprescindibles y constancia de una tensión intelectual sobre la cultura cubana. Creo que todas las intervenciones de este número pretenden ese mismo rigor y alcanzan por tanto su objetivo: estar escritas al filo de una reflexión sobre un aspecto sobresaliente de una espléndida tradición y una realidad literaria rotunda. 


\title{
INTRODUCCIÓN A LA LITERATURA CUBANA
} tica) a trabajos sobre la identidad latinoamericana en Ensayos de otro mundo o $\mathrm{Ca}$ libán. Apuntes sobre la cultura en nuestra América. Entre sus numerosos libros de poesía, traducidos a varios idiomas, destacan Alabanzas, conversaciones, En su lugar, la poesía, Circunstancia y Juana y su último poemario Aqui.

\author{
ROBERTO FERNANDEZ RETAMAR
}

\section{Para Ambrosio Fornet}

En carta de noviembre de 1957 a la que acompañaba su libro $L a$ expresión americana, me dijo José Lezama Lima: «apostillas del umbral, mancha del pintorcete. Temas que son siempre introducciones. ¿Pero qué otra cosa puede escribir el hombre que no sea introducción?». Confieso que el recuerdo de esas palabras me dio algún sosiego cuando me puse a redactar las líneas que siguen. Porque tras recibir la invitación a participar en este curso, y aceptarla alegremente, me di cuenta de que una vez más me había metido en camisa de once varas. ¿Qué sería exactamente lo que se esperaba de mí? ¿La primera parte de un curso sobre literatura cubana? ¿O una apretada síntesis de su historia toda? ¿O el esbozo de los momentos más felices o significativos de ella? Después de desechar estas opciones, o mejor de desechar absolutizarlas, me vinieron a la memoria las palabras citadas de Lezama, y comprendí que, hiciese yo lo que hiciese, se trataría siempre de una introducción. En primer lugar, porque ello es lo que corresponde a la criatura humana, según el autor de La expresión americana; en segundo lugar, porque siendo estas páginas las iniciales del curso, es ocioso subrayar ese carácter; $y$, finalmente, porque me di cuenta de que soy casi un especialista en introducciones (a disciplinas, a temas, a obras, a figuras), la que se revela incluso en el título de varios de mis trabajos, y cuando no, en el contenido de muchos otros. Esto último sin duda ha sido tomado en cuenta por los sagaces organizadores del curso, guiados por el precepto dialéctico «zapatero a tus zapatos».
De todas formas, debo admitir que, sin desdeñar del todo las opciones arriba citadas, comenzará por lo que pudiéramos llamar algunas cuestiones generales en el desarrollo de la literatura cubana y sus circunstancias. Y si bien, como es lógico, destacará lo que creo que caracteriza a esa literatura, de ninguna manera puede esperarse que se trate de rasgos aplicables sólo a ella. Ese adanismo no es mi meta, como no puede serlo de nadie en sus cabales. Además, mencionará sólo a algunos autores, salvo una excepción al final; $y$, a no ser que lo considere absolutamente necesario, prescindiré de aludir a los asuntos que van a ser considerados por otros en el curso, y en cambio insistiré en los que no lo serán.

He aquí la primera verdad que voy a hacer mía y que abarca más allá de nuestra área. Al escribir sobre literatura peruana Mariátegui hizo observar algo que es válido para cualquier literatura similar: que "el 'nacionalismo' en la historiografía literaria [...] es un fenómeno de la más pura raigambre política, extraída a la concepción estética del arte». Decir de un texto que es bello es emitir un juicio estético; decir que es una novela, un juicio literario; pero decir que es cubano no es ni lo uno ni lo otro. Pues la categoría de «cubano» (como la de «español», «francés», "peruano» $o$ «argentino») es de muy distinta naturaleza: no «geográfico-sentimental», como sugirió una vez con su gracia pendenciera, pero equivocado, Borges, sino histórica o si se quiere, política, tal como asegura Mariátegui, si a este último vocablo le damos su horizonte más vasto. Ciñéndonos a Cuba, no creo que estuviera pensando en Mariátegui ( $y$ mucho menos en el
Introducción a la literatura cubana ROBERTO FERNÁNDEZ RETAMAR 


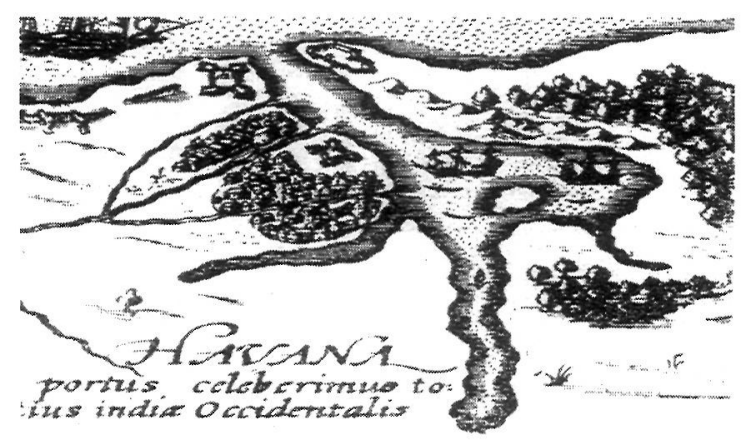

marxismo que aquél profesaba) Max Henríquez Ureña cuando, al frente del más apreciable Panorama bistórico de la literatura cubana que conozco, afirmó: «El desenvolvimiento de la vida literaria en Cuba está tan estrechamente ligado al de la historia política, que se hace imposible disociarlos». Y unas páginas después: «La historia literaria de Cuba representa, en sus líneas generales, el empeño constantemente renovado de lograr que el pueblo cubano adquiera plena conciencia de su destino histórico». Al hallarnos pues, en el orden literario, «en busca de nuestra expresión», para valernos de la fórmula clásica que propagara el hermano de Max, Pedro Henríquez Ureña, los cubanos, concientemente o no, perseguimos una expresión que no es sólo individual sino colectiva: perseguimos (con mayor o menor intensidad, con mayor o menor acierto) la consolidación de la colectividad que somos.

Otra generalidad, de área menos vasta: la literatura cubana, por obligación colonial en sus inicios, comienza como desprendimiento de la literatura española. Un desprendimiento, concretamente, de la literatura en lengua castellana, pues no creo que haya en la literatura cubana verdaderos destellos catalanes, ni gallegos, ni vascos. Por la comunidad lingüística, y por similitudes de otra naturaleza, hay que reconocer, sí, destellos canarios, de que será menester hablar a propósito del primer poema estimable escrito en Cuba que se conserva: Espejo de paciencia (1608), obra del canario Silvestre de Balboa.

En consonancia con lo anterior, las obras iniciales de la que iba a ser la literatura cubana fueron hechura de españoles. El primero, sin embargo, no la era, pues se trató del mesiánico y pintoresco genovés Cristóbal Colón, quien pergeñó las páginas inaugurales de que se tenga noticia sobre nuestra isla, páginas de previsible elogio, que hace unas décadas volvió a exaltar, entre tantos otros, nadie menos que Lezama. Sobre «las letras de Cuba antes de 1608» (fecha del poema Espejo de paciencia) dejó una erudita conferencia, que glosaré libremente, José Juan Arrom, quien después de mencionar el caso de los indígenas, sobre el que he de volver, concluye que desaparecieron sin dejar huellas; como tampoco produjo frutos literarios conservados el epidérmico contacto de españoles e indias, por lo que es necesario buscar el inicio de las letras cubanas en aquellas obras de navegantes, cronistas y colonos que se escriben en Cuba, tratan de Cuba o están íntimamente relacionadas con el desarrollo posterior de su cultura. Por descontado, se da aquí un sentido bien lato a la literariedad. Después del ejemplo ya mencionado del Diario de viaje de Colón, considerado piedra angular de las letras de Cuba, pasa a referirse a los cronistas de indias, encabezados por Las Casas, quien se entregó por completo a la tarea de defender, en lenguaje apasionado, el derecho del indígena a ser libre. El primer pasaje aducido es aquel en que narra la muerte del cacique Hatuey. Después de otros pasajes, se afirma que sería acto de justicia dar cabida en las letras cubanas a los escritos de Las Casas que atañen directamente a la isla y han fecundado a sus grandes escritores. Los otros autores aludidos no tienen la relevancia del Almirante ni del gran dominico. Pero el acucioso investigador no deja de rastrear más. A un oscuro licenciado Cabrera le atribuye lo que llama un «reportaje» de naufragios y tesoros robados, que sería incidente no desdeñable para una antigua novela de aventuras o un moderno folletín policíaco. Con criterios similares, el siglo XVI cubano puede ofrecer un muestrario, así sea magro, de cierta producción literaria. Pero, aparte de su despreocupación estética, se trata, sin duda, de una producción totalmente colonial, cuyos hacedores ni siquiera son cubanos. Y colonial seguirá siendo durante largo tiempo la literatura en Cuba. Lo que no es para sobresaltar. Alfonso Reyes ha dejado establecido que toda literatura colonial «[c]orresponde casi exactamente al concepto político, pero no del todo», y que «[e]l estado colonial es transitorio, y se encamina al estado de cultura como a una mayoría de edad».

La ya mencionada ausencia de areitos, ceremonias religiosas que practicaron los indígenas o incluían cantos y danzas, remite a la ausencia de los indígenas mismos, los cuales no sobrevivieron al impacto con los europeos. Sobre esto, Las Casas dejó vívidas páginas lancinantes. La sobrevivencia de los aborígenes sólo ocurriría en palabras, en particular en toponímicas (el mismo nombre del país es prue- 
ba de ello, pues resistió a otros como Juana y Fernandina), en la estructura de humildes viviendas llamadas bohíos, en alimentos, en costumbres como la del tabaco. Fueron vencidos de verdad y para siempre, no como en el caso del libro de Miguel León Portilla, Visión de los vencidos, ya que en el México actual (según lo recuerdan dramáticamente los sucesos de Chiapas), hay millones de descendientes de los visionarios a que se refiere el autor. En consecuencia, no hay en Cuba, paralelamente a la de origen español, una literatura indígena, así sea oral o amparada en disfraz español, como sí la hay, hasta nuestros días, en otros países americanos. Ejemplo señero de ello el del Perú, lo que ha merecido estudios bien valiosos de autores como Antonio Cornejo Polar y Martín Lienhard. Sin embargo, en el siglo XIX la memoria del extinguido indio (en especial el siboney) aparece en nuestras letras, sobro todo en nuestra poesía. Pero se trata de un recurso táctico, por lo general para objetar la colonización española, no de una auténtica reivindicación de quien ya no existía. Como una forma de rearticular la historia al margen de las etnias, y yendo más allá de Cuba, Martí escribirá a finales de ese siglo: «Se viene de padres de Valencia y madres de Canarias [fue su caso propio] y se siente correr por las venas la sangre enardecida de Tamanaco y Paramaconi, y se ve como propia la que vertieron por las breñas del cerro del Calvario, pecho a pecho con los gonzalos de férrea armadura, los desnudos y heroicos caracas». Y hace algo más de treinta años, Lezama dio al protagonista de su novela Paradiso el nombre de José Cemí: cemí se llamaba una imagen indocubana de destino religioso.

Caso bien distinto al del llamado indio es el del negro, «indígena 'importado'», según lo llamó en relación con zonas americanas más vastas Alejandro Lipschütz. Este otro «indígena» resultó elemento esencial para lo que iba a ser la cubanidad. En cuanto a lo literario, al no llegar a arraigar una de las distintas lenguas africanas traídas por los esclavos, el castellano acabó siendo su lingua franca: lo que, después de todo, les ocurrió también a los conquistadores y colonizadores, venidos de la Península y sus islas adyacentes, con el propio castellano, hecho que ya he mencionado. Por razones que desconozco (aunque sin duda fuertes emigraciones de ese origen, en determinado momento, pesaran en el hecho), en
Cuba, como en Argentina, a los descendientes de aquellos se les acabó llamando globalmente «gallegos», denominación que perduraría. (En uno de sus infrecuentes rasgos de humor, Martí dijo refiriéndose a una bailarina andaluza: « ¿cómo dicen que es gallega? / Pues dicen mal: es divina»). Así pues, en Cuba un catalán a un vasco estaba obligado a hablar castellano y a ser llamado gallego. El africano, por su parte, sería llamado negro (no obstante la variedad de sus orígenes étnicos), y obligado a expresarse también en castellano, aunque como lenguas rituales sobrevivieran varias, sobre todo el yorubá. Y en castellano dejaría ejemplos literarios como plegarias, leyendas, cuentos, refranes, originalmente producidos en lenguas africanas (así yorubá, ewe, bantú), que según don Fernando Ortiz fueron vertidos «al idioma amestizado y dialectal de los negros criollos» y sólo en este siglo iban a ser recogidos, en la estela de Ortiz, por autores como Ramón Guirao, Lydia Cabrera o Rómulo Lachatañeré. Mientras en pleno siglo XIX escritores negros o mestizos contribuían con obras de la literatura considerada «culta». Aquí es oportuno recordar que el de Cuba, en la denominación de Darcy Ribeiro, no es un pueblo «testimonio» (como los que cuentan con fuertes comunidades indígenas), ni un pueblo «transplantado» (como los que han sustituido a dichas comunidades por otras venidas de Europa), sino un pueblo «nuevo", en que todos sus componentes han venido de fuera (sobre todo de España y África), y conocerían un proceso que en 1940 Ortiz llamará «transculturación», y no ha concluido.

El primer centro de la América española estuvo en las Antillas, en la vecina isla de Santo Domingo. Pero el conocimiento de extraordinarios imperios del Continente desplazó hacia éste el interés metropolitano. Después de la conquista, hacia 1510, y la fundación de las siete primeras villas, Cuba perdió su relativa preeminencia: de ella partieron, entre muchos aventureros que casi la dejaron despoblada, Hernán Cortés hacia la conquista de México (1519), y Hernando de Soto hacia la Florida (1539). Sólo entre 1516 y 1520 salieron de Cuba no menos de dos mil españoles en esas expediciones. A mediados de siglo, el número de personas libres se estimaba en seiscientos a setecientos; los indios, cerca de cien mil al empezar la conquista, no pasaban de cinco mil; los negros sumaban ya alrededor de
Introducción a la literatura cubana ROBERTO FERNÁNDEZ RETAMAR 


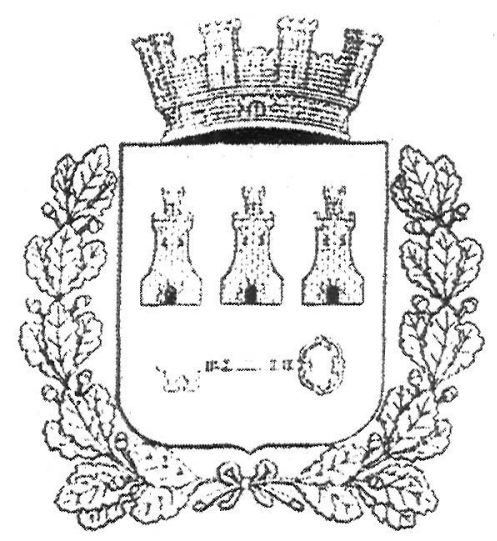

setecientos. La población tenía ya, pues, los caracteres de una típica factoría colonial, prevaleciendo los siervos y los esclavos. Aunque siguió trasvasando formas españolas por lo general asaz rudimentarias, quedó en efecto como menguada factoría, en que el sistema monopolista que España impuso a sus colonias sólo era roto por la piratería internacional y el frecuente contrabando. Precisamente en relación con estas últimos se produce la primera obra concientemente literaria producida en la Isla: el ya mencionado poema épico Espejo de paciencia, que data de 1608 y cuyas candorosas estrofas, escritas en la villa de Puerto Príncipe, tratan de un encuentro no de españoles e indios, como en La Araucana, de Alonso de Ercilla, sino de nativos y piratas. Su autor, Silvestre de Balboa Troya y Quesada, Era bastante enigmático para nosotros. Apenas se sabían sus fechas esenciales y que, habiendo nacido en las islas Canarias, estaba radicado en la Antilla mayor. Pero Cintio Vitier, cuidadoso editor de la pieza, me ha comunicado de viva voz un dato que a su vez le trasmitieron los hermanos Manuel y Eugenio Padorno, de dichas islas. En ellas, Balboa habría participado en la academia poética de Bartolomé Cairasco de Figueroa, quien mantenía relaciones con algunos clásicos de la lengua. El poema, pues, no es el resultado de una evolución literaria interna de que entonces carecíamos aún, sino el trasplante de un producto canario, adaptado a un tema y a aspectos ambientales del nuevo hogar del poeta. No se limitó a ello Balboa, sino que, a semejanza de aquella academia poética que conociera en su archipiélago atlántico, había atraído al cultivo de las letras a varios habitantes de la región, los cuales le dedicaron sendos sonetos laudatorios: de sus autores, tres habían nacido en la misma villa cubana. Sin entrar ahora en otros pormenores, vale la pena subrayar que tanto en el texto como en uno de los sonetos que lo preceden aparece el vocablo «criollo». Aquí de nuevo debo volver a Arrom, autor del mejor estudio que conozco sobre "Criollo: definición y matices de un concepto». Según tal estudio, el vocablo había nacido en el portugués del Brasil, de donde se difundiría por otras lenguas. Antes de concluir el siglo XVI, era común y corriente por todo el Nuevo Mundo, donde implicaba haber nacido allí, de ascendientes venidos del Viejo, sin importar el color de la piel, el estado político o la condición social. En efecto, en Espejo de paciencia, un blanco «mancebo galán» es llamado «criollo del Bayamo», y un negro, «Salvador criollo, negro honrado»; mientras Pedro de las Torres Cifuentes ofrece a Balboa un «soneto criollo de la tierra», donde no deja duda del carácter local del término: es «de la tierra». Se trata de un protoapunte en que lo cubano comienza lentamente a diferenciarse de lo europeo y lo africano. Recuérdese, de paso, que un importante personaje del jocundo Concierto barroco, de Alejo Carpentier, Filomeno, es presentado como «biznieto de un negro Salvador, que fue, un siglo atrás, protagonista de una tan sonada hazaña que un poeta del país, llamado Silvestre de Balboa, la cantó en una larga y bien rimada oda, titulada Espejo de paciencia...». Es curioso este deseo tanto de Lezama como de Carpentier de entroncar con el pasado insular en sus obras de ficción.

Pero la diferenciación entre «español»o «africano»y «criollo» no avanzará mucho más en Cuba hasta finales del siglo XVIII. La isla, mientras tanto, es avivada por la confluencia de las Flotas españolas que, de regreso a España cargadas de metales preciosos, hacen escala en La Habana. Para poder defenderla de piratas y corsarios, la ciudad es provista desde finales del siglo XVI con grandes fortificaciones que aún hoy despiertan la admiración de los turistas. Cuba suple así su carencia de oro y plata con su ubicación geográfica excepcional, que le ganará el epíteto de Llave del Nuevo Mundo, a la que pronto sumará algunos productos locales. La estancia de las Flotas y la construcción de fortalezas significan dinero y esclavos que se van traduciendo en el incremento de industrias incipientes: ganadería, azúcar, tabaco, maderas. Una clase formada por propietarios agrícolas nativos empieza a desarrollarse, se levantan residencias e iglesias de un suave barroquismo, se introduce la imprenta y se funda una Universidad, en La Habana. Las letras cubanas entre 1700 y 1790 (estudiadas en una buena monografía por Enrique Sainz) son harto discretas, e incluyen la pieza teatral El Principe jardinero y fingido Cloridano, obras de versificadores que merecerían ser destacados por Lezama en su singular Antología, de oradores eclesiásticos elogiados por Sainz y de los pri- 
meros historiadores de la isla: señal de una naciente autoconciencia.

La Época es sacudida por un acontecimiento mayor. En 1762 los ingleses, en guerra contra España, tomaron La Habana. Allí permanecieron un año, durante el cual el tráfico comercial fue muy intenso. El hecho puso a los cubanos en contacto estrecho con otras formas de vida, al mismo tiempo que los hizo conscientes de su importancia, y obligó a España a prestar más atención a Cuba. Sin embargo, en la defensa de La Habana, los héroes españoles y los criollos aún peleaban juntos. La nacionalidad cubana no estaba todavía diferenciada de la metropolitana. Incluso algunos años después los prohombres de la Isla seguirían considerándose "españoles de Ultramar».

Pero a la devolución de La Habana, que España cambió a Inglaterra por la Florida, va a sucederse una serie de hechos directa o indirectamente relacionados con Cuba, y causantes de su súbita transformación. Así, las modificaciones de la política colonial española, reflejo del despotismo ilustrado de Carlos III; la independencia de lo que serían los Estados Unidos; la Revolución Francesa, cuya repercusión en Saint Domingue (antes y después llamado Haití) y el bloqueo a que varias metrópolis someten al primer país independizado de nuestra América, arruinan su industria azucarera y permiten a Cuba asumir su papel; la sublevación de las colonias suramericanas, y la emancipación de los esclavos en las Antillas británicas. La circunstancia de contar con gobiernos alerta, como el de don Luis de Las Casas (1790-1796), permitió a Cuba propiciar los cambios necesarios, especialmente en cuanto a la importación de esclavos, para estar en condiciones de asumir el papel productor dejado vacante por Haití. Además, el auge creciente de los Estados Unidos ofrecía a los productores de la isla un mercado importante que pronto fue oficialmente tolerado por el gobierno español, enzarzado en nuevas guerras con Inglaterra y Francia.

Arrastrada al mercado capitalista mundial, Cuba fomentó su riqueza sobre bases deplorables: la esclavitud, que se multiplicó para poder hacer frente al creciente trabajo de la industria azucarera; y la concentración de tierras, que aunque no llegó a los desastres del latifundio moderno - el cual no fue posible sino hasta el arribo de grandes capitales estadounidenses- preparó su camino. Industrias como la tabacalera y la cafetalera fueron echadas a segundo sitio con el predominio del azúcar. La sacarocracia iniciaba su reinado. Sometida al régimen de plantaciones característico de las Antillas, Cuba se convertiría en la azucarera del planeta.

Sobre esta base, los criollos blancos dueños de plantaciones, que de «españoles de Ultramar» acabarían proclamándose cubanos, alcanzaron un estadio superior de existencia, que ha quedado cristalizado en la imagen que algunos europeos suelen hacerse de la vida en una rica colonia del trópico, y la franco-cubana condesa de Merlín presentó en su obra $\mathrm{La}$ Havane (1844). El ferrocarril fue introducido en 1037, antes que en España, y vinculado a las exigencias de la industria azucarera. Se crearon instituciones sociales y culturales, se construyeron teatros, avenidas y suntuosas residencias. «Durante este período» pudo decir el historiador estadounidense Leland $\mathrm{Ha}$ milton Jenks, «fue Cuba la colonia más rica del mundo. En muchos aspectos de cultura material y artística llegó a sobrepasar a España». Una de las empresas intelectuales de la época, la Revista Bimestre Cubana (18311834), era, a los ojos de Pedro Henríquez Ureña, «la mejor revista literaria, por entonces, de todos los países de lengua española, sin excluir a España».

Este instante cubano se inicia en torno a 1790. Más de uno ha dicho que el siglo XIX alborea para Cuba ese año, en que se inicia el gobierno de don Luis de Las Casas, aparece, con su patrocinio, el que sería el órgano iluminista y neoclásico del patriciado cubano del momento, El Papel Periódico de la Havana [sic] (que durará con ese nombra hasta 1805), y es ya evidente la transformación de lo que fue una factoría en una colonia de plantaciones en vías de contradictoria modernización. Casi imperceptiblemente empieza a asomar la contradicción colonia/metrópoli, que al principio se manifiesta, tímidamente, en rasgos locales, elogios a las frutas del terruño debidos a poetas como Manuel de Zequeira y Arango en su «Oda a la piña», o en diálogos entre las frutas europeas y las nuestras, como en la «Silva cubana» atribuida a Manuel Justo de Rubalcava: son apenas barruntos de diálogos que encontrarán interlocutores mucho más dramáticos que el aguacate y la pera. Pero para
Introducción a la literatura cubana ROBERTO FERNÁNDEZ RETAMAR 


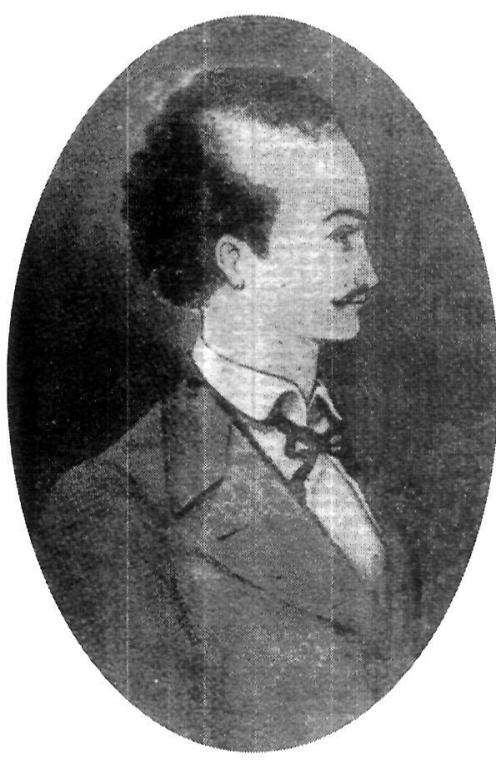

Gabriel de la Concepción Valdés, «Plácido». esa clase emergente, tal contradicción habrá de ser sofocada durante décadas por otra: la contradicción esclavistas/esclavos. No es extraño, por ello, que al estallar la revolución hispanoamericana de independencia a partir de 1810 - una revolución del patriciado frente a España-, Cuba no se sumara al proceso secesionista. La oligarquía criolla, que se tiene por blanca y aspira a convertir al país en una nación moderna (hoy diríamos que de capitalismo desarrollado), aunque llega a desear el poder políti$\mathrm{co}$, tiene fundados temores de que una revolución pudiera arrastrar tras sí las grandes dotaciones de esclavos y transformar el sentido de la guerra, como había ocurrido en Haití. Tal oligarquía no va más allá de una actitud reformista que encarna con triste lucidez el activo y moderado Domingo del Monte, una de las principales cabezas culturales, quien confesó que pagaban el delito de tener esclavos siéndolo ellos mismos.

Las dos contradicciones metrópoli/colonia, esclavistas/esclavos van a recorrer buena parte del siglo XIX (aunque la esclavitud fue abolida por los insurrectos en 1868, tardó en serlo por España hasta 1886), y se expresarán enérgicamente en el pensamiento y las letras del país. Sólo los independentistas se hallaban dispuestos a zanjar ambos dilemas. Para reformistas (partidarios de permanecer unidos a una España que en vano querían políticamente flexible) y anexionistas (quienes veían la solución en incorporarse a unos Estados Unidos entonces esclavistas), la esclavitud resultaba, a la vez, fuente de riqueza y dogal. Y en las primeras décadas de ese siglo eran escasos los intelectuales independentistas. Mencionaré a los dos más destacados. (Ellos, además, son los primeros creadores de gran nivel de los géneros reyes de nuestras letras, si aceptamos para Cuba que dichos géneros, como Ángel Rama dijo en relación con toda Hispanoamérica y es criterio que comparto, son la poesía y el ensayo, los cuales, a juzgar por los títulos de las conferencias, serán poco tratados en el curso en lo que toca al siglo XIX; y tampoco lo será mucho el ensayo en el siglo XX). Me refiero ahora a José María Heredia y Félix Varela. Al hablar de cada uno, añadiré algo sobre el desarrollo de los géneros respectivos hasta las vísperas del fin del siglo pasado.

Significativamente, Heredia y Varela son los más destacados intelectuales cubanos de su tiempo, y al abrazar el independentismo, desbordan las posibilidades de su clase de origen en ese momento, lo que los obligará al destierro. El más joven de ellos, Heredia, es también de extraordinaria precocidad. Antes de los nueve años hace versos; a los diecisiete, ya es uno de los mejores poetas vivos del idioma: entonces escribe el primer texto mayor de la poesía cubana, «En el teocalli de Cholula»; a los diecinueve años, conspira por la libertad de su patria y se ve obligado a exiliarse; vivió en adelante en Estados Unidos y México, donde murió. A diferencia de poetas cubanos que lo precedieron, Heredia no es un mero inventarista de la naturaleza insular: su rebeldía y su poder de descripción, su cultura y su nostalgia interiorizan el paisaje insular, lo funden al sentimiento de una peculiaridad nacional que vemos asomar en sus versos de arte mayor, mientras escribe los iniciales poemas políticos del país. De Manuel Pedro González en adelante se lo ha considerado nuestro primer poeta romántico. Canta al mar, al Niágara, a la tempestad, a la libertad, al amor, a las ruinas, en cálidas estrofas en las que la tradición española es visiblemente enriquecida no sólo por una firme educación clásica, sino por nuevas voces francesas, inglesas, italianas. Martí, que lo juzgó admirablemente y lo llamó el primer poeta de América, decía que en sus versos aprendió a ser cubano. Pues en su poesía Heredia sella el sentimiento de singularidad del cubano, y fija los símbolos de su tradición, palma o estrella. Opuesto tanto al régimen metropolitano como al crimen de la esclavitud, es un parricida no sólo en lo que toca a España, sino a su clase, la cual, atemorizada, abandona a este precoz heraldo de cubanía, pero reconociéndole su genio literario, que también se manifestó en piezas dramáticas, cuentos y críticas. Al morir en 1839, a sus treinta y cinco años, era indiscutible que $\mathrm{Cu}$ ba perdía a su primer gran hombre de letras.

Convenimos en considerar ya abiertamente nuestra inicial generación romántica la de los poetas Gabriel de la Concepción Valdés, Plácido, y José Jacinto Milanés. Plácido, artesano mulato, es la primera figura notable de nuestras letras en no ser blanca ni provenir, consecuentemente, de las clases adineradas. 
Aunque sin su jerarquía literaria, fue antecedido por un hombre singular: Francisco Manzano, esclavo de gran talento que al cabo será manumiso por Del Monte y su grupo. A pesar de su origen, ninguno de los dos produce obra poética en que se exprese su condición social ni la tragedia de su raza. Su poesía se acomoda a los esquemas criollos blancos, que van separándose de los propiamente españoles. En cambio Manzano nos ha dejado un documento con escasos pariguales en cualquier sitio: el relato de su propia vida, la autobiografía de un esclavo negro en la Cuba esplendorosa y atroz de aquellos años. Tanto Plácido como Manzano fueron involucrados por los gobernantes españoles en la Conspiración de la Escalera - llamada así debido al tipo de tormento al que se sometía a los inculpadosen 1843-1844, con la que se quiso castigar a las numerosas revueltas de negros y mestizos, sofocar el desarrollo de una incipiente pequeña burguesía de aquéllos, y en general atemorizar a los criollos. Plácido fue fusilado, y Manzano dejado en libertad, pero queriendo que se lo olvidara no volvió a escribir una línea más.

Milanés representa una intelectualidad criolla ya en abierta pugna con España. Anticolonialista, antiesclavista, no proviene del patriciado; por el contrario, modesto empleado de provincia, es la encarnación de una pequeña burguesía radicalizable, destinada a un papel revolucionario en nuestra historia. Poeta romántico de intenso eticismo, con frecuencia mezcla a sus notas de delicada ternura (en que el paisaje de Heredia se hace más suave) alusiones abiertas a la libertad y a la independencia; o desarrolla temas nativistas que alcanzarán su cima con la generación siguiente. También escribió piezas teatrales, ellas no alcanzaron la envergadura de las de su coetánea Gertrudis Gómez de Avellanada, extraordinaria autora en verso y prosa que se disputan Cuba y España.

Aunque la segunda generación romántica prolongaría muchas actitudes anteriores, sus dos notas más características son el desarrollo de una poesía nativista que se vale con frecuencia de la exaltación del desaparecido indígena; y el acendramiento de la lírica. Entre otras figuras de menor calidad, lo primero será realizado sobre todo por Juan Cristóbal Nápoles Fajardo, El Cucalambé, que sigue siendo el poeta más popular en nuestros campos. Entregado a la descripción de la vida en dichos campos con fines nacionalistas, anticolonialistas, dio con una expresión genuina y llevó a su cima una línea de criollización de la poesía española iniciada a principios de siglo. Esa poesía había conocido, casi paralelamente, dos propulsores mayores: uno, de extracción popular, Francisco Poveda, El Trovador Cubano; y otro, rico exponente del patriciado, el ya nombrado Domingo del Monte. Ninguno de ambos era un gran poeta, pero sus obras nos permiten asistir a una curiosa mutación de funciones de las formas Poéticas. Del Monte, conservador tanto en lo político como en lo literario, al proponerse una poesía criollista, recurre al

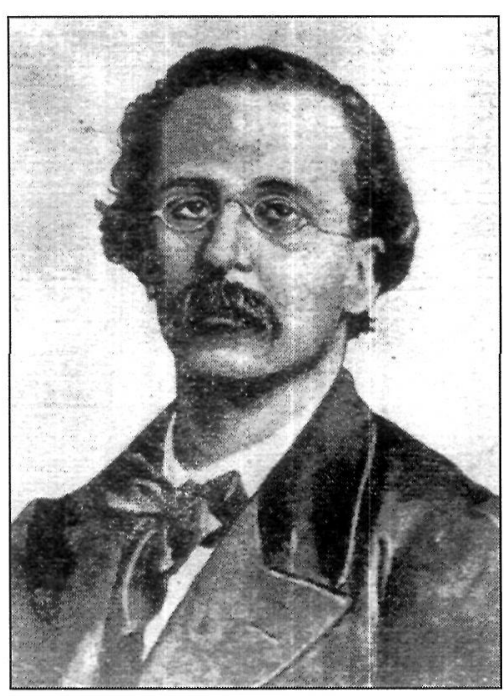

Juan Clemente Zenea. romance, la estrofa tradicionalmente popular en España, pero no en Cuba, no obstante valerse Del Monte de asuntos campesinos cubanos; Poveda, hombre más elemental en su formación y auténtico campesino, se atiene a la espinela o décima, que a pesar de su origen culto había venido aclimatándose en los campos de Cuba y otros países americanos, al punto de hacerse la forma habitual, hasta nuestros días, de las improvisaciones del campesino o guajiro, correspondencia cubana de las improvisaciones del payador rioplatense. En las décimas de El Trovador Cubano, de $E l$ Cucalambé, de numerosos poetas anónimos (cuyas obras no empezarían a recogerse hasta que Samuel Feijoo lo hiciera en 1961) se anunció, y se despedazó, un posible Martín Fierro insular.

La otra nota valiosa del período está dada por un conjunto de poetas en que se afina la sensibilidad romántica. Aunque esta línea es iniciada por Rafael María de Mendive, maestro de Martí, el nombre descollante de esta etapa es el de Juan Clemente Zenea, una de las voces más transparentes y puras de la poesía cubana, quien expresará en nocturnos y elegías la desazón de un poeta delicado a quien su deber empuja al combate y que no logra estar siempre a la altura de las circunstancias. Como Plácido, murió fusilado por los españoles. Su estancia, desterrado, en los Estados Unidos, le permitió familiarizarse con la literatura de aquel país, sobre la que escribió estudios que parecen haber influido en Bécquer, cuyas Rimas aparecieron el año del fusilamiento del cubano. Con la obra de Zenea se suele empa-
Introducción a la literatura cubana ROBERTO FERNÁNDEZ RETAMAR 


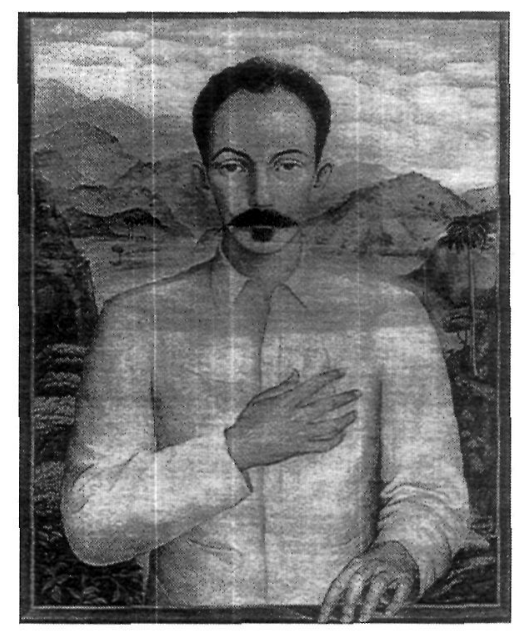

José Martí, en un óleo de Jorge Arche (1943). rentar la de la intensa elegíaca Luisa Pérez de Zambrana, mientras Joaquín Lorenzo Luaces produjo una poesía más diversa, donde a ratos se anuncia el parnasianismo, y cultivó también el teatro. Al estallar en 1868 la primera parte de la guérra de independencia, apuntaba una nueva generación que tendrá como tarea histórica fundamental dicha guerra, y luego se manifestará en otros géneros (meditativos, críticos), de preferencia a la poesía. Con esta generación, el romanticismo se extingue como fuerza creadora en nuestra poesía. Otra época comienza, durante las últimas décadas del siglo, en toda Hispanoamérica: la encabeza el llamado modernismo, que en Cuba tendrá dos altos representantes en José Martí y Julián del Casal. Martí, precisamente en el obituario que dedicó a Casal, ofreció en 1893 la mejor definición del aún discutido modernismo, que él no nombró así:

en América está ya en flor la gente nueva, que pide paso a la prosa y condición al verso, y requiere trabajo y realidad en la política y en la literatura. Lo hinchado pasó, y la política huera y rudimentaria, y aquella falsa lozanía de las letras que recuerda los perros aventados del loco de Cervantes. Es como una familia en América esta generación literaria, que principió por el rebusco imitado, y está ya en la elegancia suelta y concisa, y en la expresión artística y sincera, breve y tallada, del sentimiento personal y del juicio criollo y directo.

Las dos vertientes principales de la poesía martiana son la de sus "versos libres» y la de sus «versos sencillos». Los primeros, que sólo aparecerán póstumamente, en 1913, son endecasílabos sin rima, con encabalgamientos ásperos y violentas imágenes de filiación barroca. Uno de los primeros en conmoverse ante estos poemas fue Unamuno, quien los comparó a los salmos hebraicos y a Whitman: al parecer, ellos influyeron en su Cristo de Velázquez. La otra vertiente de la poesía de Martí comprende las dos obras que publicó: Ismaelillo, donde injertó las rápidas visiones de la poesía moderna (entre cuyos fundadores estuvo, como destacó Rama) en las formas de los villancicos tradicionales; y su libro de plena madurez, Versos sencillos, algunos de cuyos poemas, con un reconquistado sabor popular de coplas americanas, se han cantado en el mundo con la tonada de La guantanamera (tonada que para Carpentier es la de un romance traído por los conquistadores), lo cual no puede hacer olvidar la insondable complejidad de su sencillez, que preludia notas machadianas.

La otra figura notable del modernismo en Cuba, el doliente Julián del Casal, representa el costado del movimiento que fue más visible en sus primeros momentos, con fuerte impronta de parnasianos y simbolistas franceses. Dejó discípulos que se vincularían a la guerra reiniciada en 1895 , en uno de cuyos primeros combates murió Martí.

Dejando atrás la poesía de Cuba en el siglo XIX, entremos en otra área. Si Heredia fue el inicial gran hombre de letras del país, al presbítero Félix Varela le correspondió rango similar en lo que toca al pensamiento: José de la Luz y Caballero, maestro mayor, lo llamó «el primero que nos enseñó a pensar». Pero no compete ahora detenernos en esa esencial faena suya, que por otra parte le costó vivir lejos del país, debido al inconmovible independentismo al que arribó; murió en los Estados Unidos, por cierto el mismo año, 1853, en que murió Del Monte y nació Martí. Lo que voy a destacar es un juicio emitido sobre él por José Antonio Portuondo, quien en su Boceto histórico de las letras cubanas afirmó: «En la obra de Varela es tan constante la preocupación por los problemas políticos y sociales que ha hecho olvidar sus méritos extraordinarios de escritor, a pesar de que su Miscelánea filosófica (1819) lo revela como uno de los mejores ensayistas de nuestra lengua». Lo notable de esta cita estriba en que Portuondo, que fue un crítico cuidadoso, hablara de «ensayistas» refiriéndose a una obra de principios del siglo XIX, cuando el ensayo, como género, tardaría aún bastante en ser reconocido en nuestra lengua toda, no obstante los ilustres precedentes extranjeros que se remiten a Montaigne, acuñador del propio vocablo. Lo que, desde luego, no quiere decir que no se practicara en español, pero sí que no tenía nombre ni perfil definido. El juicio de Portuondo incita a que estudiemos la posible existencia de ensayos, incluso en el ámbito reducido de la literatura cubana, al menos desde el siglo XVIII. Puestos a conjeturar, se debe atender también el caso de otros géneros. 
Por ejemplo, Cintio Vitier, Fina García Marruz y Roberto Friol, compiladores de la antología La literatura en el Papel Periódico de la Havana, reunieron los materiales de su selección en los acápites «Crítica y polémica», «Cuentos», «Poesía» y «Teatro». El primer acápite, presentado por García Marruz, ¿no contiene algunos de nuestros primeros ensayos, varios de ellos atribuidos al Padre José Agustín Caballero? El segundo acápite no deja lugar a la duda: su presentador, Roberto Friol, asegura que el cuento cubano nació allí, con lo que contradice otras hipótesis. Y más allá de dicha compilación, aunque el testimonio es para muchos un género de este siglo, de estas décadas (sólo en 1970 fue convocado un premio de testimonio, por la Casa de las Américas), ¿no son testimonios muchas de las obras de los cronistas de Indias?; ¿no Es un testimonio la Excursión a Vueltabajo, de Cirilo Villaverde?; y en trabajo reciente, Michèle Guicharnaud-Tollis pudo establecer un paralelo entre la autobiografía de Manzano y una obra clásica del testimonio contemporáneo: Biografía de un cimarrón, de Miguel Barnet.

Baste lo anterior para no incurrir en el fetichismo de los géneros; $y$, de momento, volver a los ensayos, todavía sin ese nombre. Si Varela llamó a varios de los suyos Miscelánea filosófica, José Antonio Saco (quien había dirigido la Revista Bimestre Cubana) agrupó un vasto conjunto de los debidos a su pluma en tres volúmenes de Papeles sobre Cuba. No todos ellos son ensayos; pero muchos sí, y están escritos en una prosa vibrante y ardiente de polemista. Saco, además, acometió la redacción de una enorme Historia de la esclavitud que aun inconclusa sigue siendo uno de los monumentos de la cultura cubana. Es significativo que sus Papeles los dedicara a la memoria de Domingo del Monte, señal inequívoca de su identificación con el gran animador de la cultura cubana, reformista como Saco y enemigo como él de la esclavitud. Saco, si bien quería hacer cesar la trata y abolir la esclavitud, consideraba que la nacionalidad cubana (a la cual defendió con vigorosa tenacidad frente a los anexionistas) era asunto de blancos, y propugnó por ello el blanqueamiento del país, una de sus obsesiones, lo que ha hecho que se le compare con Sarmiento. Sus admoniciones $\mathrm{y}$ advertencias no fueron tomadas en cuenta por el gobierno español, que lo obligó a vivir en el destierro, donde murió (como Varela,
Heredia, Del Monte). Fue, según Portuondo, «la voz más alta del patriciado»; su obra, «el examen más agudo y perdurable de las raíces de nuestra nacionalidad». Después de él, sólo serían posibles las revolucionarias, que acabarían situando en el eje del país a sectores medios y populares con voceros como Antonio Macea y José Martí.

Entiendo que la conferencia «Literatura y pensamiento en el fin del siglo XIX» considerará a otras de nuestras importantes ensayistas de la centuria: pienso en autores como $\mathrm{Ma}$ nuel Sanguily, Enrique José Varona y, sobre todo, el mayor de nuestros escritores, Martí. Mientras, evidentemente, la «Narrativa cubana del siglo XIX» se hará cargo de lo que anuncia. Tendremos así un cuadro de lo fundamental de nuestras letras en un siglo del que hay que decir que si se inició en 1790 , concluyó, desastrosamente por partida doble, en 1898. En ese año, la intromisión estadounidense en la guerra entre España y Cuba (que había recomenzado en 1895), no sólo venció a ambas, hecho en verdad infrecuente, sino que convirtió a la segunda en tierra ocupada militarmente, y luego en protectorado y neocolonia, hasta 1958, ejerciendo el poder por lo general a través de gobiernos títeres.

Mirando retrospectivamente a la literatura cubana de la centuria pasada, sendas observaciones llaman la atención, una desde la derecha y otra desde la izquierda. La primera es de don Marcelino Menéndez y Pelayo, según el cual «el espíritu general de los literatos y de los hombres de ciencia en Cuba ha solido ser sistemáticamente hostil a España y manifestarse francamente como tal». La segunda es de Martí, cuya obra estuvo tan nutrida no sólo de literaturas extranjeras, sino de lo mejor de los clásicos de su idioma; lo cual no le impidió decir, aludiendo a su contemporaneidad, que «los pueblos de habla española nada, que no sea manjar rehervido, reciben de España». El siglo había separado a las literaturas de ambos países, como había separado a los países mismos, no obstante permanecer políticamente unidos. Pero a partir de 1898 las cosas no seguirían siendo así.

En el siglo XX se ha puesto el énfasis del curso, y apenas me es necesario añadir gran cosa. Como ya adelanté, sin embargo, echo de menos una conferencia que abordara en conjunto su ensayo. No pienso suplirla (entre otras cosas, porque carezco de tiempo),
Introducción a la literatura cubana ROBERTO FERNÁNDEZ RETAMAR 
pero no quiero desaprovechar la oportunidad para señalar, a propósito de tal ensayo, un par de cosas. La primera, la nueva relación que en este siglo se establecería entre la exmetrópoli y la ex-colonia. Quizá el ejemplo inicial sonado la ofrezca el libro de ensayos de don Fernando Ortiz Entre cubanos... Psicología tropical, aparecido en 1913 y encabezado por dos cartas a Unamuno, cuya huella es visible en toda la obra, al extremo de que ella fue señalada por Carlos Serrano como ejemplo de "regeneracionismo trasatlántico». En la segunda de aquellas cartas, Ortiz le asegura al rector salmantino: «y es que $\mathrm{Cu}$ ba, en no pocos aspectos, es más española que España». En trabajo más serio sobre el tema, de 1940, «Los factores humanos de cubanidad», Ortiz volverá a citar con identificación a Unamuno.

Unamuno dejará su huella en varias generaciones de ensayistas cubanos. Ortega y Gasset habrá de hacerlo sobre todo en integrantes de la generación que empezó a manifestarse en la tercera década, como fue el caso destacado de Jorge Mañach (en su coetáneo y contradictor Marinello, las raíces españolas miran más a los barrocos). Y María Zambrano, en la generación posterior, sobre todo en el grupo que se nucleó en torno a la revista Orígenes: Vitier y García Marruz se contaron entre sus discípulos. A propósito de ese grupo, aunque no suele recordarse como debiera, las conferencias que García Lorca ofreció en La Habana en 1930 (en especial la que dedicó a la imagen poética en don Luis de Góngora) estimularon la ensayística deslumbrante de Lezama. Menciono lo anterior tan sólo como muestras de la presencia española en nuestro ensayo del siglo. Más allá del ensayo, es sabido que Juan Ramón, García Lorca, Alberti, Aleixandre, Cernuda y otros poetas españoles también se hicieron sentir en la poesía cubana. El final desdichado de la guerra civil española interrumpiría por largo tiempo esa fértil relación. Pero ese es otro cantar.

Lo segundo que diré a propósito del ensayo cubano de esta centuria tiene ver con el tratamiento de determinadas cuestiones que es propio del género. Si en el siglo pasado el ensayo había considerado problemas entonces en discusión, otro tanto hará éste. Sólo que los problemas, desde luego, no serán ya los mismos. A la contradicción metrópoli/colonia le ha sucedido la de metrópoli/protectorado o neocolonia (siendo ahora la metrópoli no España, sino los Estados Unidos); a la contradicción esclavistas/esclavos, la que opone a la viceburguesía o burguesía desnacionalizada (la cual ocupó el sitio de la clase que perdió su oportunidad histórica al finalizar la Guerra de los Diez Años, en 1878, y cuyo epitafio fue el Pacto del Zanjón) y a los sectores medios y populares que ascendieran a primer plano en la Guerra de 1895, con un ideario revolucionario diseñado por Martí. Truncada aquella guerra en 1898, su proyecto quedó como una «revolución pospuesta», según dijera el historiador Ramón de Armas. El siglo XX será atravesado por tales contradicciones, $\mathrm{y}$ muchos de sus ensayistas se harán cargo de ellas. Se trata de un entramado complejo que apenas puedo rozar aquí. En general, conscientes de la condición capitidisminuida del país, los ensayistas de la primera generación republicana, sobre todo los reunidos en torno a la inicial revista importante del siglo, Cuba Contemporánea, defienden la nación frente a la prepotencia estadounidense, pero sin asumir una posición fuerte ni una perspectiva clasista popular. Entre quienes irán más lejos en aquella generación habrán de contarse el propio Ortiz, José Antonio Ramos y Emilio Roig de Leuchsenring. Corresponderá a la segunda generación hacer frente a las contradicciones con todo su fuego. Varios de sus integrantes redescubren, deslumbrados, a Martí. Julio Antonio Mella y Rubén Martínez Villena introducen el marxismo en el pensamiento cubano, y lo aplican creadoramente a desentrañar nuestros problemas. Mella aporta el primer análisis marxista de Martí; y Martínez Villena escribe Cuba, factoría yanqui, paralelamente a los Siete ensayos de Mariátegui. Intelectuales como ellos, como muchos de quienes se expresaron en, la heterogénea revista Social, en la vanguardista Revista de Avance y en la más fugaz y radical América Libre, habían formado parte desde 1923 del Grupo Minorista, inclinado a la izquierda, al que de modo sorpresivo le apareció entre sus filas un fascistizante: Alberto Lamar Schweyer. Su libro Biología de la democracia, después de algunas escaramuzas, provocó, como réplica, una «Declaración» del Grupo que en 1927 redactó Martínez Villena y fue, paradójicamente, el canto de cisne de dicho Grupo. El país, impulsado por el rechazo al régimen tiránico de Gerardo Machado, iba a tratar de acome- 
ter la «revolución pospuesta». Como consecuencia de ello, los más agudos editores de Revista de Avance (que se extingue en 1930), Mañach y Marinello, acabarán separándose, asumiendo el primero posiciones conservadoras, y sumándose el segundo al comunismo. Al cabo, la revolución vuelve a ser pospuesta: para 1935, se ha ido «a bolina», según dijera años después Raúl Roa, uno de nuestros más apasionados ensayistas políticos. El país entraba en otro período oscuro y corrupto, con la nueva tiranía, intermitente, de Batista, que regresa al poder con el golpe de Estado de 1952. Al año siguiente, el 26 de julio de 1953 , Fidel Castro y sus jóvenes compañeros asaltan dos cuarteles en Oriente, y vuelven a intentar la «revolución pospuesta». El autor intelectual, declara Fidel, es Martí; su programa, La historia me absolverá. Después de conocidas luchas épicas, el primero de enero de 1959 la revolución, al fin, llega al poder. Cuba alcanza su independencia, e inicia una transformación profunda que asume carácter socialista y pronto cumplirá cuarenta años.

Doy por sentado que el curso presentará lo realizado durante ese lapso en varios géneros. El ensayo predominante será sobre todo político e histórico, pero abordará también otras áreas. Lo ejercen figuras de varias generaciones: Marinello, Roa, Carpentier, Portuondo, Mirta Aguirre, Carlos Rafael Rodríguez, Julio Le Riverend, Lezama, el Manuel Moreno Fraginals de El ingenio, Vitier, García Marruz, Tomás Gutiérrez Alea, Julio García Espinosa, Ambrosio Fornet, Edmundo Desnoes, Jorge Ibarra, Lisandro Otero, Leonardo Acosta, Graziella Pogolotti, Rine Leal, Miguel Barnet, Nancy Morejón, Ana Cairo, Víctor Casaus, Joel James, Desiderio Navarro, Rogelio Martínez Furé, Fernando Martínez Heredia, Pedro Pablo Rodríguez, Raúl Hernández Novás, Luis Toledo Sande, Abel Prieto, Rosa Ileana Boudet, Nara Araújo, Rafael Hernández, Luisa Campuzano, Francisca Ló- pez Sacha, Margarita Mateo, Jorge Luis Arcos, Arturo Arango, Enrique Ubieta, yo (no me queda más remedio que citarme, para no parecer coqueto, así como a mi compañera Adelaida de Juan), muchos y muchas más. Una figura adquiere relieve mundial: el Che. En los últimos años, además de revistas ya existentes, como Casa de las Américas y La Gaceta de Cuba, se han creado otras destinadas a acoger ensayos nuevos: Temas y Contracorriente son ejemplos de ellas. Algunos permanecen al margen de la discusión política, como Severo Sarduy, Julio Rodríguez Luis, Roberto González Echevarría, Emilio Bejel. Y, por supuesto, no han faltado ensayistas hostiles a la Revolución, con frecuencia tránsfugas, también con frecuencia continuadores (en pleno auge del imperialismo estadounidense y del «pensamiento único» de derecha) de los anexionistas del siglo pasado, cuando no émulos de Lamar Schweyer. Equivalen a «los que no tienen fe en su patria», los «letrados artificiales», ornados de «falsa erudición», que fustigó Martí en Nuestra América.

Voy a concluir esta introducción pensando en lo que brota, y reiterando algo que dije hace treinta años, al final de una charla sobre antipoesía y poesía conversacional en Hispanoamérica que me solicitó Mario Benedetti:

No conviene olvidar el carácter pendular del arte [...]. Hay muchos rasgos que nosotros no podemos prever en estos momentos y que es posible que engendren una poesía [en esta ocasión debemos decir: una literatura] de la que no tenemos noción. El arte, como la historia toda, según decía Marx, suele tomar el otro camino, «Esa otredad que padece lo uno», de que hablaba Antonio Machado, puede estar ahora mismo oyendo la conversación, y ella va a decir la última palabra. Que, desde luego, no será la última. 


\begin{abstract}
José Carlos Rovira
Catedrático de Literatura Hispanoamericana en la Universidad de Alicante. Ha publicado numerosos estudios y ediciones sobre autores y movimientos literarios españoles e hispanoamericanos, entre ellos, Miguel Hernández, Pablo Neruda, José María Arguedas, poesía novohispana, Ilustración e Inquisición en América, reflexiones en torno a la identidad cultural, etc. En la actualidad ha centrado sus investigaciones en la literatura del período colonial hispanoamericano.
\end{abstract}

\section{Remedios Mataix}

Profesora de Literatura Hispanoamericana en la Universidad de Alicante. Su actividad docente e investigadora ha dedicado una atención especial a la literatura cubana y sus relaciones con los procesos políticos y culturales del siglo XX. Ha dedicado varios artículos y libros a la obra de José Martí y, sobre todo, de José Lezama Lima y el Grupo Orígenes. Actualmente orienta su investigación hacia la literatura colonial y, en concreto, a la obra del Inca Garcilaso de la Vega.

José Lezama Lima y la fundación imaginaria de la literatura colonial cubana

JOSÉ CARLOS ROVIRA REMEDIOS MATAIX

\title{
JOSÉ LEZAMA LIMA Y LA FUNDACIÓN IMAGINARIA DE LA LITERATURA COLONIAL CUBANA
}

\author{
José CARLos RoviRA Y REMEdIOS MATAIX
}

La tradición, como en la célebre frase sobre la libertad, es un don, pero es también una conquista. José Lezama Lima

Hablamos desde la perspectiva de una cultura emergida con fuerza desde el siglo XIX, todavía en el período de la Colonia, acrecentada con pasión en la Independencia - la pasión intelectual de José Martí, por ejemplo-, y rotunda en el siglo que llevamos desde aquel 1898: Cuba es, con tantos países de Latinoamérica, un espacio privilegiado de emergencias múltiples y universales. Pero hablamos precisamente desde la perspectiva de un tiempo no emergente que es el de la casi inexistencia de una tradición literaria durante los siglos de la Colonia.

La cuestión inicial que queremos señalar es efectivamente ese problema de lo casi inexistente. Hasta la Ilustración cubana, casi hasta el libro Llave del nuevo mundo de José Martín Félix de Arrate, a mediados del siglo XVIII, rastreamos con dificultad la literatura culta en Cuba. Otro problema es el de las tradiciones populares, el romancero o la cultura global de la negritud. Pero textos literarios impresos no hay, y además no puede haber en Cuba hasta 1721, que es cuando se establece en La Habana la primera imprenta. Si no hay imprenta no habrá literatura impresa y eso explica, no que ésta no pudiera haber sido escrita, sino que difícilmente se pudiera preservar por el resguardo de la letra impresa. Un texto como el renombradísmo Espejo de paciencia de Silvestre de Balboa, que abre el siglo XVII, y cuya transmisión impresa es un efecto muy posterior, es el único soporte conocido de esa literatura colonial que buscamos previa a la de la sociedad ilustrada.

\section{CUBA Y LA CARENCIA DE UNA TRA- DICIÓN LITERARIA}

Si la Isla de Cuba fue el enclave inicial de la Conquista, si muy pronto en ella se establece un espacio de colonización necesaria como puerta para la llegada al Continente de los conquistadores y colonizadores, ¿por qué no tenemos una sociedad que, como la que se conforma a partir de 1520 en Nueva España (México) y poco después en el virreinato del Perú, cree entre sus establecimientos civiles la imprenta, la Universidad y una capa de intelectuales y escritores capaces de dar cuenta desde el principio de una producción literaria, de realizar la misma? El fenómeno parece obvio y determinante. La Imprenta está en México desde 1530 y, sin embargo, en Cuba casi dos siglos después. En 1519 Cortés decide la refundación de Tenochtitlán, como México, en el mismo espacio en el que había destruido la ciudad azteca tras su guerra de dos años con Moctezuma. Pero ese mismo año, a bastantes millas de distancia, se producía la tercera fundación de la Villa de San Cristóbal de la Habana en la costa norte de Cuba, trasladada desde la costa sur donde en 1514 se había fundado por primera vez. Y empezaron años prometedores pero difíciles para la corona española en Las Antillas. La rivalidad con Francia, las guerras con el país vecino, se trasladaron 
también al Caribe. La piratería asediaba el codiciado puerto de San Cristóbal de La Habana. En 1537 la villa es saqueada y quemada por primera vez por la piratería que sirve a Francia para romper la hegemonía comercial que España está teniendo. En 1555, otro filibustero francés, Jacques de Sores, arrasa e incendia de nuevo San Cristóbal. A partir de aquí, ingleses y holandeses entran en la contienda para dominar el puerto crucial de entrada a América. Allí se abastecen los barcos para retornar hacia el Sur de España con su cargamento de oro. Francis Drake, Robert Baal o Henry Morgan son nombres conocidos de sucesivos asedios.

La destrucción de 1537 intenta repararse con audacia. La corona española nombra a Hernando de Soto capitán general de Cuba y adelantado en la Florida. Dos años ejercerá de capitán general antes de su aventura en La Florida quien tiene como objetivo fortificar San Cristóbal y la isla. La construcción de La Fuerza en el puerto de La Habana se inicia en 1539. Las instrucciones de la corona le pedían a De Soto que intentase «un cortijo a manera de ciudadela en el morro que está cerca del puerto». De Soto debía estar pensando en otras cosas. En la joven Inés de Bobadilla, en la búsqueda de la fuente de la eterna juventud para contrarrestar la diferencia de edad con su enamorada, o en la aventura de La Florida que lo debía convertir en otro capitán glorioso como el afamado Cortés. Decidida la construcción de La Fuerza, a trescientos pasos del actual Castillo de La Real Fuerza, partió para la Florida en 1539, dejando a Mateo Aceituno como maestro mayor de obras quien a partir de 1540 sería alcaide de una fortaleza que acabó siendo bastante inútil. Pero esta historia inicial de la fortificación de la isla, diremos, no tiene más objetivo que entrelazar desde el comienzo unos nombres que sí fueron literarios y fundacionales. Y presentar la realidad de la Isla fortificada y amenazada.

No parece que fuera el acoso de la piratería al mayor puerto de comercio, ni la llegada de aventureros que a partir de allí iban a buscar otras tierras de promisión, o permanecían en las encomiendas a las que muy pronto iba a nutrir, por la mortandad de indígenas, el componente importado y esclavo de la negritud, terreno abonado para conformar una sociedad estable que pudiera dedicarse a labores intelectuales. La llave del nuevo mundo era un terreno inestable civilmente, un lugar de paso en sus ciudades principales, un lugar peligroso por el asedio marítimo al que fue sometido. Las fortalezas, la Real Fuerza comenzada a construir hacia 1558, o el Fuerte de San Salvador de la Punta, o el Castillo de los Tres Reyes del Morro, construidos a final de siglo dan cuenta del alto significado militar de la ciudad y del uso de grandes recursos para este fin.

\section{SIN EMBARGO SÍ HAY UNA LITERATURA FUNDACIONAL}

Ocurre necesariamente con la literatura cubana, como en toda la tradición hispanoamericana, que su fundación se realiza en el descubrimiento y en las tradiciones previas existentes de las antiguas civilizaciones. En Cuba, al contrario que en México y Perú, no hay una articulación cultural consistente previa. Es decir, no afloran vestigios de una civilización precolombina. Los pueblos indígenas que existían, esa población de unos cien mil individuos que despareció casi totalmente en la dureza de la avidez conquistadora, los taínos, subtaínos y guanahatabeyes, distribuídos por el territorio como pueblos agrícolas y cazadores, no habían afianzado ni desarrollado un sistema cultural comparable a la grandeza de los pueblos de México o de la cordillera andina.

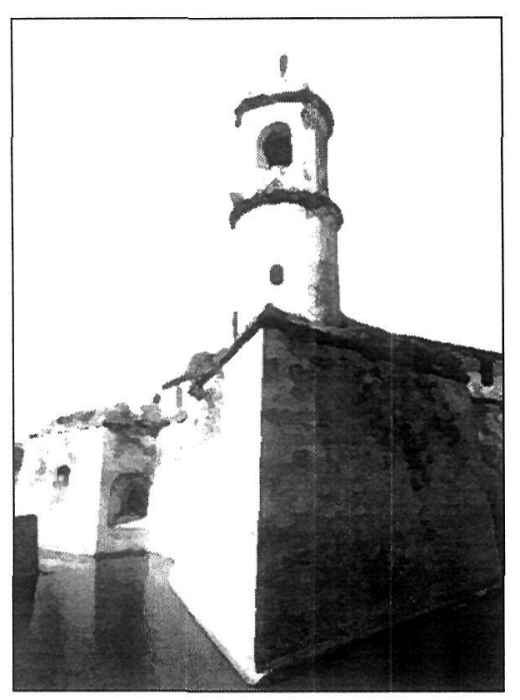

Fortaleza de El Morro (La Habana).

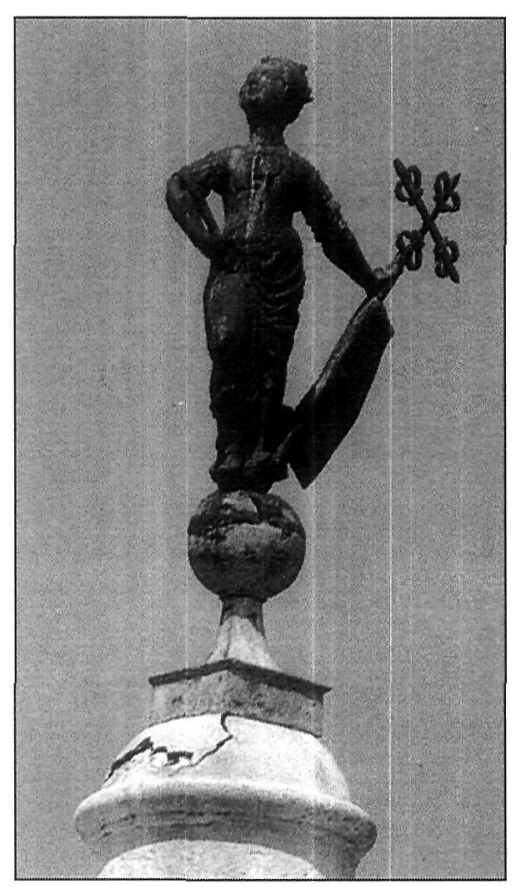

La Giraldilla.
El descubrimiento sin embargo nos ofrece los primeros textos culturales sobre la Isla, en una fundación que tiene los mismos parámetros organizadores que los de la literatura hispanoamericana, pues varias de las voces principales de la crónica del siglo XVI se afincan en tres discursos principales: el originario y fundacional de Colón, el de la violencia de Fray Bartolomé de las Casas y, cerrando el siglo, las primeras evocaciones urbanas de la isla a través del Inca Garcilaso de la Vega. Colón, Fray Bartolomé y Garcilaso, paradigmas esenciales de la crónica de Indias en tres líneas principales, son los fundadores de la escritora sobre el espacio de Cuba. Pero ¿por qué no hablar, co-
José Lezama Lima y la fundación imaginaria de la literatura colonial cubana

JOSÉ CARLOS ROVIRA REMEDIOS MATAIX 
José Lezama Lima, «Preludio a las eras imaginarias» (1958) en Las eras imaginarias, Madrid, Fundamentos, 1971, pág. 22.

2

José Lezama Lima, Prólogo a Antología de la poesía cubana, La Habana, Consejo Nacional de Cultura, 1965, 3 vol. Lo tomo de Confluencias. Selección de ensayos, Selección y prólogo de Abel Prieto, La Habana, Editorial Letras Cubanas, 1988, pág. 101.

3

Cristóbal Colón, Textos y documentos completos, edición de Consuelo Varela, Madrid, Alianza Universidad, 1984, pág. 21.

4

Confluencias, cit. pág. 101.

5

José Lezama Lima, «Paralelos. La pintura y la poesía en Cuba (siglos XVIII y XIX), Casa de las Américas, 7(41), marzo-abril 1967. Lo recojo de La cantidad hechizada, Madrid, Júcar, 1974, págs. 7-8. mo haría seguramente José Lezama Lima, de fundadores de la literatura cubana?

\section{JOSÉ LEZAMA LIMA Y SU FUNDA- CIÓN IMAGINARIA}

De las distancias que José Lezama Lima nos produjo, cuando leíamos disciplinadamente Paradiso a fines de la década de los sesenta o en años posteriores, de las incomprensiones que determinaron la primera lectura de su poesía, hemos podido pasar algunos al apasionamiento con una obra ensayística, poética y narrativa que forma un sistema coherente de creación y pensamiento. Con la misma coherencia poética que La ciencia nueva de Vico — de la que Lezama se sentirá deudor afirmando sus posiciones contra el racionalismo de Cartesio, citado siempre así en obvia concesión a la tradición clásica del nombreLas Eras imaginarias de Lezama construyen un universo posible y repleto de signos, que no mueren pues son «señales» y la señal, dice Lezama:

comienza en la teoría o desfile a hora y júbilo señalados. En la vacilación del cortejo por aparecer, en la prosecución de la pareja, en el solitario deseado coincidente, también el signo rubrica la posibilidad de la aparición ${ }^{1}$.

Una poética de lo imaginario avant la lettre, y no establecida en el sentido de la moderna teoría del imaginario, sino a través del entrelazamiento de lo posible, conforma una aventura intelectual nutricia y repleta de sugerencias. En ella, Lezama, entre tantas otras fundaciones, se apresta a la del pasado de $\mathrm{Cu}$ $\mathrm{ba}$, recorriendo signos poéticos posibles, señales, en un cortejo que tiene en su aparición los nombres que establecimos antes: Colón o Hernando de Soto, por ejemplo:

Nuestra Isla comienza su historia dentro de la poesía. La imagen, la fábula y los prodigios establecen su reino desde nuestra fundamentación y el descubrimiento. Así el Almirante Cristóbal Colón consigna en su Diario, libro que debe estar en el umbral de nuestra poesía, que vio caer, al acercarse a nuestras costas, un gran ramo de fuego en el mar. Ya comenzaban las seducciones de nuestra luz ${ }^{2}$.

José Lezama Lima y la fundación imaginaria de la literatura colonial cubana

JOSÉ CARLOS ROVIRA REMEDIOS MATAIX lón, el 15 de septiembre de 1492, exactamente así:

Navegó aquel día con su noche XXIII leguas su camino al Güeste y algunas más. Y en esta noche al principio d'ella vieron caer del çielo un maravilloso ramo de fuego en la mar, lexos d’ellos cuatro o cinco leguas?3.

Otras imágenes recorren el texto fundacional, hasta llegar a una primera propuesta:

En esos primeros años del descubrimiento, la imaginación y la realidad se entrelazan, los confines entre la fabulación y lo inmediato se borran ${ }^{4}$.

Estamos ya ante una poética fundacional construida a través de un fenómeno descrito en 1492 por Colón que se entrelaza a una metáfora sobre la luz en Cuba. Ya tenemos un texto originario por tanto. Una era imaginaria aparece en una era histórica y José Lezama Lima no dejará de insistir en ella.

Otro ejemplo que además nos divierte. Les vamos a introducir brevemente en otra era imaginaria a propósito del episodio fundacional que acabamos de narrar. Se trata del comienzo de «Paralelos. La poesía y la pintura en Cuba» ${ }^{5}$. Es de 1966. El texto dice así:

Antes de saltar embebido las clavijeras amarras, el misterioso surcador Cristóbal Colón se aposenta demorado frente a unos tapices: Ha cruzado una poderosa llanura, lo que debe haberle producido la sensación de una navegación inmóvil, está en un extremo de Castilla la Vieja y entra para oír misa de domingo en la Catedral de Zamora. Siente la grandeza de uno de los más hermosos tapices que existen, que compite con dignidad castellana con $L a d a-$ ma y el unicornio, de Cluny. Uno de los tapices entreabre las guerras de Troya, con el rapto de Elena. En el centro, una barca medieval de gran tamaño, los mástiles ganan la altura del tapiz, aparece un marinero de extraña catadura, muy barbado, soltando el ancla, otro marinero recoge las amarras. Rimas provenzales limitan el panel, en torno del mástil, como palomas. Después está la tienda de Aquiles, en su fondo el ulular de la batalla. Bosque de lanzas y estandartes, abriéndose en el bosque los ojos de las damas para contemplar las murallas de Ilión. El caballo blanco de Aquiles, un doncel rubio sostiene las riendas. Alternan cerca de la tienda los griegos y los orientales, más parecen susurrar sus murmuraciones los comerciantes, que su vanagloria los guerreros. Las ropas son de nobles bi- 
zantinos, algunas parecen venidas de Catay o de Cipango. Un grupo de damas contempla aisladamente a un caballero, que penetra en el mar de los combatientes con un desenfado singular. En los otros tapices las muertes de Aquiles, Troilo y Paris. Los caballos se recubren con unas gualdrapas tan guarnecidas como el manto que cubre el elefante de un rajá. Aparecen curvados barcos, como góndolas de la serenísima. Debajo de los muros y las ruinas estallan las flores como llamas torneadas. Un caballero pisotea las rosas de más sonriente amanecer. Las interminables llanuras de flores se confunden con las más presuntuosas alfombras persas con motivos de venatoria. Cuando el Almirante va recogiendo su mirada de esos combates de flores, de esas escaleras que aíslan sus blancos como aves emblemáticas, del arquero negro cerca de la blancura que jinetea $\mathrm{Ta}$ nequilda, y las va dejando caer sobre las tierras que van surgiendo de sus ensoñaciones, se ha verificado la primera gran transposición de arte en el mundo moderno. De esos tapices ha saltado a tierra, y los blancos fantasmales, las cabelleras de las doncellas y los arqueros sombríos han comenzado a perseguirlo y arañarlo.

Las imágenes reafirman la propuesta de Lezama. Colón ha entrado a misa dominical en la catedral de Zamora y unas imágenes le asaltarán para siempre, se convertirán en una compañía que salta con él a la tierra americana: blancos fantasmales, cabelleras de doncella y arqueros sombríos le persiguen para siempre. O las ropas de estos griegos que parecen venidas de Catay o de Cipango. Todo un salto en un vacío imaginario y fundacional, en una transposición artística que tiene que ver con la fusión del imaginario europeo (aunque habla de «la dignidad castellana» de los tapices) y las nuevas tierras recién descubiertas.

La propuesta de Lezama es básica, como sabemos, para un programa artístico de rescate del pasado, para convertir al mismo en «materia artizable»:

Entre nosotros es casi imposible configurar una tesis o un punto de vista aproximativo sobre nuestro pasado, ya de poesía, ya de pintura, porque los diversos elementos larvales aún no se han escudriñado, ni siquiera señalado su regirar ectoplasmático. Si no aparecen las larvas, cómo vamos a abrillantar el caparazón. Lo larval sólo podemos captarlo en sus mutaciones, en su devenir para llegar a ser un cuerpo, una forma, una materia artizable 6
Sólo que el escudriñamiento lezamiano de lo larval aquí no parece verdadero, por muy bello que resulte este encuentro dominical de Colón con los tapices zamoranos ${ }^{7}$. O alcanza la dimensión de lo más verdadero, una era imaginaria, en la que el arte de unos tapices hizo su transposición al nuevo mundo en aquel primer encuentro. Lezama sabe seguramente que el encuentro con los tapices es suyo, que no puede estar atestiguado en ninguna parte el del intrépido navegante, puesto que los tapices no están en la Catedral más que desde 1608, por una donación, que consta documentalmente del duque de Alba y Aliste. Entre las deducciones de dónde podían estar los tapices en la época que cuenta, tapices que Lezama ve en su «dignidad castellana», seguramente estarían en un taller de Tournai, gran centro flamenco de los tapices europeos, puesto que parecen ser del último tercio del siglo $\mathrm{XV}$. O a lo mejor estaban ya en poder de don Ínigo López de Mendoza, conde de Tendilla - el hijo de aquel otro homónimo conocido como marqués de Santillana y gloria de nuestra literatura del XV - cuyo escudo de armas preside las piezas.

No, Colón no pudo ver los tapices que Lezama sitúa como fantasmas para el imaginario en las nuevas tierras. Un desmitificador de Lezama, como Horts Rogmann, diría: «veis, Lezama se equivoca otra vez» ${ }^{8}$, en su manía por demostrar que Lezama citaba por citar y muchas veces lo hacía mal. Sin darse cuenta, como nos hemos dado cuenta nosotros, de que Lezama nos estaba permitiendo con su error (voluntario) cifrar el imaginario americano en su fusión al imaginario de unos tapices flamencos. Sabemos entonces que es grandiosa su fusión fundacional que nos ha permitido hablar sobre lo inexistente. En cualquier caso, sabemos también que Colón hizo mal en no ver los tapices.

\section{RECORRIDOS POR OTRAS SECUEN- CIAS FUNDACIONALES}

Los caminos fundacionales asumen inmediatamente otras referencias. Puede ser, por ejemplo, Pedro Mártir de Anglería y la evocación de un fragmento de la Isla que aparece en
6 Ibídem, pág. 13.

7

En el texto ya citado Prólogo a Antología de la poesía cubana, pág. 102, atenúa Lezama la seguridad del encuentro: «...cuyos temas aparecen en los bellisimos tapices de la catedral de Zamo$\mathrm{ra}$, que sin duda alguna deben haber sido vistos por Colón e impregnaron poderosamente su fantasía viajera».

8

Horts Rogmann plantea este tipo de «desmitificación» en "Anotaciones sobre la erudición en Lezama Lima», Coloquio Internacional sobre la obra de José Lezama Lima: Poesía, Université de Poitiers, Madrid, ed. Fundamentos, págs. 77-84. 
Lezama, Confluencias, cit., pág 101-102.

\author{
10 \\ Lezama, Confluencias, cit., pág. \\ 104. \\ 11 \\ Lezama, Confluencias, cit., pág.
} 106

\section{2}

José Carlos Rovira, «La imagen reflejada en el Espejo de paciencia de Silvestre de Balboa», Coloquio Imágenes recíprocas e imaginarios nacionales (Cuba, Puerto Rico, Filipinas y España) a fines del siglo XIX, Madrid, Casa de Velázquez-CSIC, septiembre de 1998 (en prensa).

\section{3}

Lezama, «Introducción a un sistema poético", en Tratados en la Habana (1958). Lo tomo de Confluencias, cit., pág. 334.

14

Lezama, "A partir de la poesía», La cantidad hechizada, La Habana, Unión, 1970, pág. 387.

José Lezama Lima y la fundación imaginaria de la literatura colonial cubana

JOSÉ CARLOS ROVIRA REMEDIOS MATAIX las Décadas, que califica Lezama de «descripción meramente imaginativa»:

...todo es templado de humedad, todo rico en productos acuíferos. Sus cuevas, como tantas bocas abiertas, desembuchan toda el agua de los ríos. Allí hay cavernas horrorosas, hay valles oscuros, hay rocas calcáreas,

para puntualizarnos a continuación:

La visión que tiene de nuestro país este cronista es la de su semejanza con Sicilia, cuyo recuerdo en la realidad y en la mitología está lleno de remolinos, cavernas, ríos, rocas. Se observa la tendencia a tener una perspectiva mitológica, aun en la realidad de lo que le rodea, paisaje, flora, fauna. Así relata Pedro Mártir de Anglería que un manatí fue cogido joven por un cacique haitiano, alimentándolo en sus lagunas. $\mathrm{El}$ animal creció amigado con el hombre. Acudía al llamamiento de Mato Mato y venía a comer en las manos. del cacique. Recogía sobre su lomo a hombres y mujeres, y los llevaba a la otra orilla como cuentan de los delfines en el mundo antiguo?.

Transposiciones de paisajes, desde islas europeas a Cuba, o secuencias mitológicas como fundación larval a través de Pedro Mártir de Anglería; o la presencia inmediata en el espacio fundacional de Hernando de Soto:

La imagen se va imponiendo a lo caótico y a la fabulación oscura. Aparece el genitor por la imagen, don Hernando de Soto, el enterrado y desenterrado. Su imagen sigue engendrando después de muerto [...] Ya a fines del siglo XVI, la imagen creada por el genitor Hernando de Soto tiene un punto de apoyo, la ciudad está presta a su defensa porque tiene el convencimiento de su importancia como llave del país ${ }^{10}$,

recordándolo otra vez en $L a$ cantidad hechi$z a d a$, en el episodio de su encuentro en el Castillo de la Fuerza con Juan Ponce de Léon, buscador de la fuente de la eterna juventud; y recorriendo el episodio de De Soto hasta su muerte, la espera por parte de Inés de Bobadilla en la Habana, la muerte de ésta. El Inca Garcilaso le sirve esta vez de apoyatura para este otro fragmento fundacional.

Pero será precisamente a comienzos del siglo XVII donde Lezama situará un episodio menos imaginario en su materialidad textual, aunque más intenso en sus imaginaciones na- cionales: Espejo de paciencia del canario-cubano Silvestre de Balboa, poema que

revela el nacimiento de modos y maneras cubanas, que a pesar de la influencia española tenemos que interpretar como algo cubano que quiere ganar su contorno y tipicidad"1.

Lezama ha escrito varias veces sobre esta obra, de la que nos dice que «desde que se escribió este poema ya se podía hablar de lo cubano, más que en lo externo en la presencia compleja de la poesía», llegando por tanto a una fundación nacional aislada en 1606 en Manzanillo de Cuba de toda una tradición posible. Recientemente hemos podido privilegiar el poema de Balboa, como base de una lectura acumulativa y crítica que, abriéndose en el siglo XIX y continuándose por todo el nuestro, provocaba que sucesivos lectores se hubieran ido asomando al espejo de Balboa, reflejándose en él y creando con sus reflejos una perspectiva nacional creciente desde el siglo XIX ${ }^{12}$. La idea de aquella reflexión nos la provocó otra vez Lezama Lima con un motivo de partida que decía así:

Está dispuesto José Martí, y es esa su imago más fascinante junto con su muerte, a llenar el contenido vacío de ese espejo de paciencia ${ }^{13}$.

En aquella reflexión comprobamos que Martí no había llenado directamente el espejo de Balboa, pero que la metáfora de llenar el espejo vacío había atraído lecturas nacionales. Y atribuciones erróneas a Martí en relación con esta obra.

\section{POR ÚLTIMO ¿DE QUÉ EMERGENCIA ESTAMOS HABLANDO?}

De lo que hemos estado hablando entonces es de la capacidad de sugerencia inagotable que José Lezama Lima tuvo, también para fundar con retazos larvales una tradición inexistente o desconocida, su capacidad para reinventar lo desconocido porque, como dijo otra vez,

La imantación de lo desconocido es por el costado americano más inmediata y deseosa. Lo desconocido es casi nuestra única tradición ${ }^{14}$.

Las posibilidades son infinitas en su juego imaginario $y$, en todo caso, sirven para des- 
montar, o para montar de nuevo, una época inexistente y convertirla en una imaginaria, junto a su capacidad larvadamente mordaz para desmontar una historia de la literatura chata, codificada y estéril. Todos recordamos aquel momento esencial de Paradiso donde reflexiona sobre la literatura y lo posible, sobre la imaginación en definitiva:

En ese momento Cemí se aprovechó para colocar una banderilla. La crítica ha sido muy burda en nuestro idioma. Al espíritu especioso de Menéndez y Pelayo, brocha gorda que desconoció siempre el barroco, que es lo que interesa de España y de España en América, es para él un tema ordalía, una prueba de arsénico y de frecuente desbarro. De ahí hemos pasado a la influencia del seminario alemán de filología. Cogen desprevenido a uno de nuestros clásicos y estudian en él las cláusulas trimembres acentuadas en la segunda sílaba. Pero penetrar a un escritor en el centro de su contrapunto [...] eso lo desconocen beatíficamente. Por ejemplo, en Góngora, es frecuente la alusión a las joyas incaicas, sin embargo, no se ha estudiado la relación de Góngora con el Inca Garcilaso, en el tiempo en el que ambos coincidieron en Córdoba. Los incas en la imaginación de Góngora; he ahí un delicioso tema. Las verdaderas relaciones de Góngora con el Conde de Villamediana, se desconocen o se silencian, a pesar de las constantes alusiones de Quevedo. La imaginación retrospectiva, tan fundamental como cuando crea mundos o simples planetas fundantes, tiene un placer interminable, los relatos que le hacía el Inca Garcilaso a Góngora de una de las eras imaginarias, la piedra despidiendo imágenes, tienen que ha- ber sobresaltado los sentidos del racionero mayor, en el momento en el que se llevaba una enorme ración para su metáfora y su venablera ${ }^{15}$.

Hemos estado hablando entonces de esa «imaginación retrospectiva», de la emergencia de lo posible, como configuración de sugerencias que, en el caso de la literatura cubana, significaban una reinterpretación de secuencias, fragmentos, hipótesis, invenciones que han sido en nuestro siglo fundacionales. Caben otros parámetros para adentrarnos en la tradición cubana en la época de la colonia. Hablamos al principio de tradiciones como el romancero y la negritud. Pero José Lezama Lima, desde su obsesión por los orígenes y por su emergencia universal, optó por otra tradición, en cuanto podía fundar a través de ella una universalidad imaginativa e imaginaria en la que pudiera reconocerse también la cultura cubana y universal del próximo siglo. En realidad, no fue otro el proyecto del grupo que él encabezó:

La poesía, lo que ya se puede llamar con evidencia los poetas de la generación de Espuela de plata, querían hacer tradición, reemplazándola, donde no existía (...) Querían que la poesía que se elaboraba fuera una seguridad para los venideros. Si no había tradición entre nosotros, lo mejor era que la poesía ocupara ese sitio, y así habría la posibilidad de que en lo sucesivo mostráramos un estilo de vida ${ }^{16}$.

Lezama dixit.
15

José Lezama Lima, Paradiso, edición de Cintio Vitier, Madrid, Archivos, 1988, págs. 240-241.

16

Lezama, "Después de lo raro, la extrañeza», Orígenes n 6 (1945), pág. 52. 
«Antes de saltar embebido las clavijeras amarras, el misterioso surcador Cristóbal Colón se aposenta demorado frente a unos tapices...»

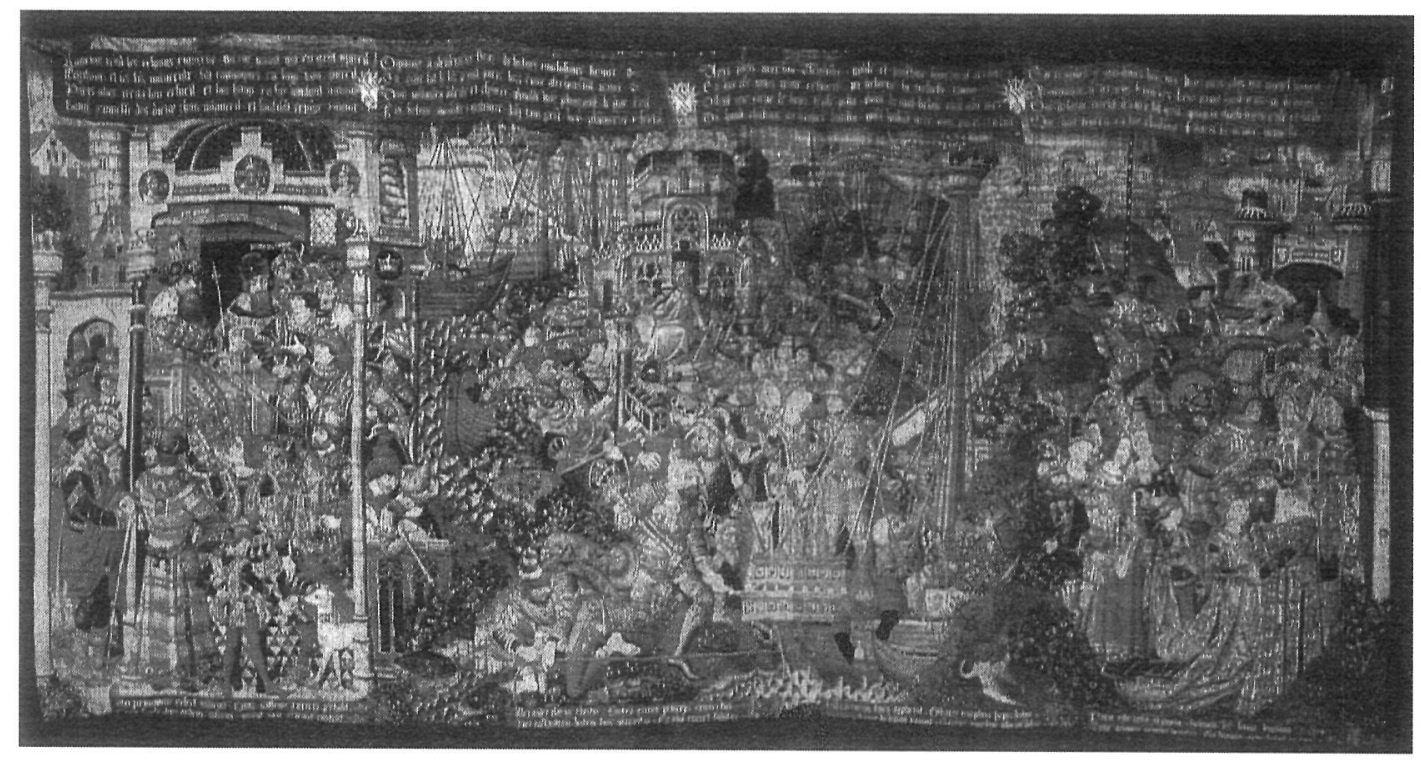

LÁMINA 1. Medidas: 9,30 metros largo × 4,50 metros alto.

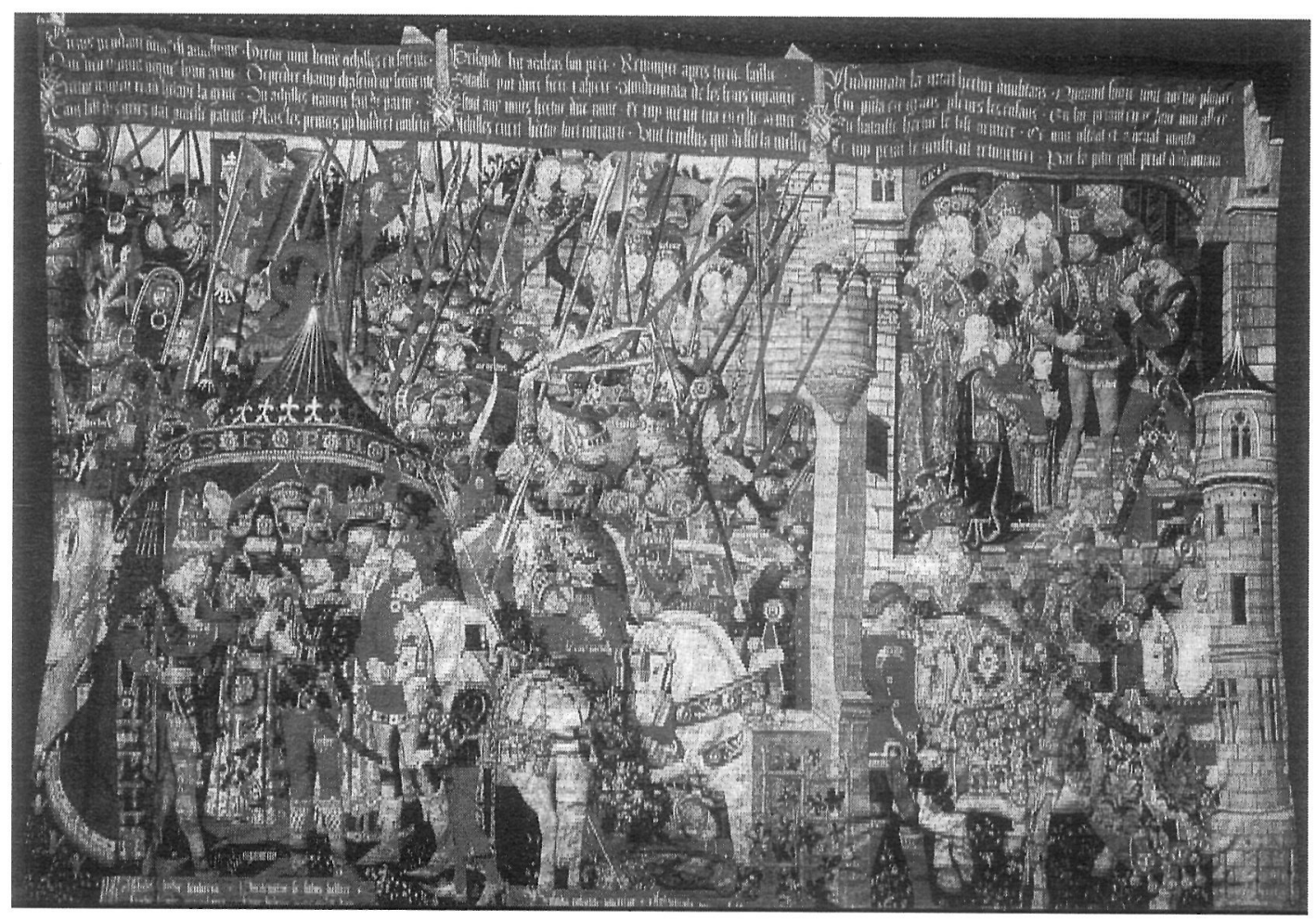

LÁMINA 2. Medidas: 6,90 metros largo × 4,67 metros alto. 
«...De esos tapices ha saltado a tierra... Se ha verificado la primera gran trasposición de arte en el mundo moderno...»

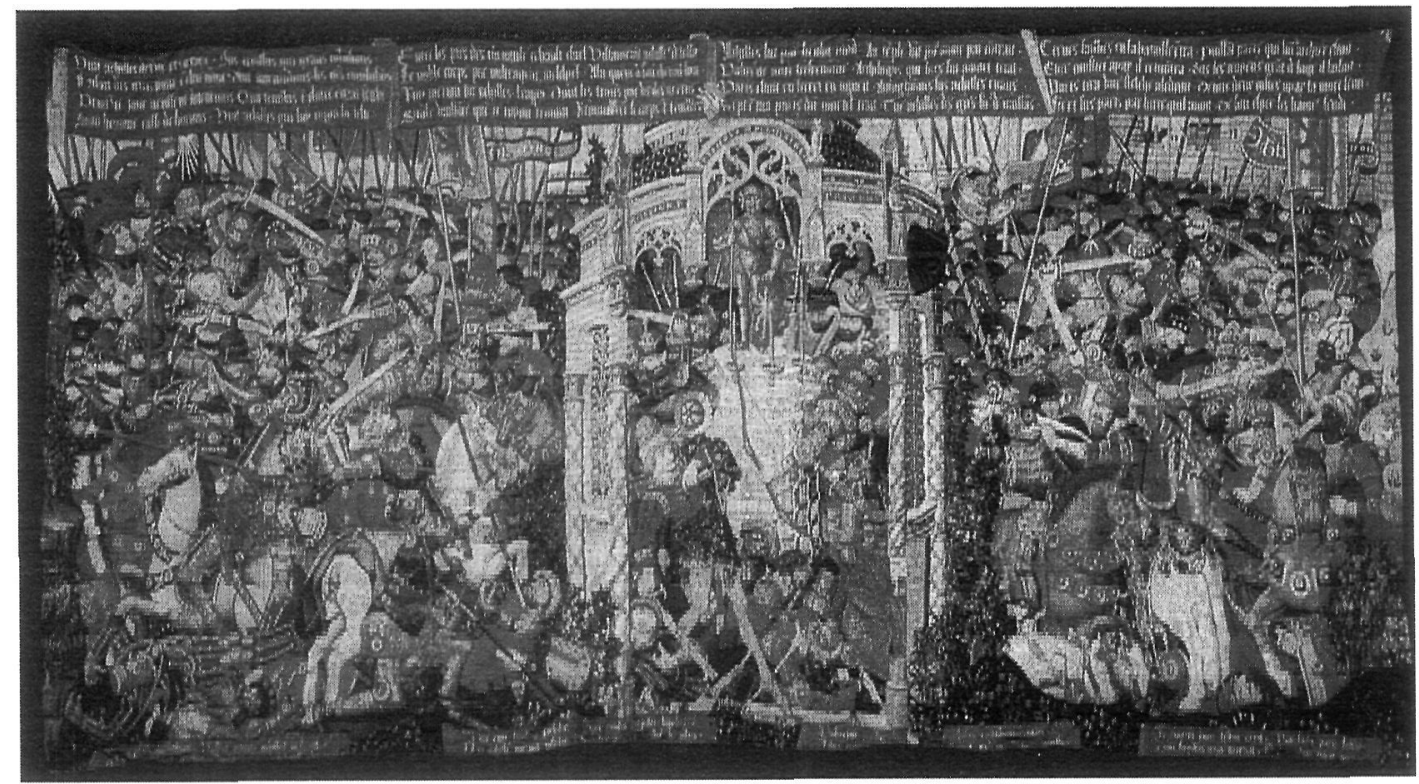

LÁMINA 3. Medidas: 9,42 metros largo x 4,81 metros alto.

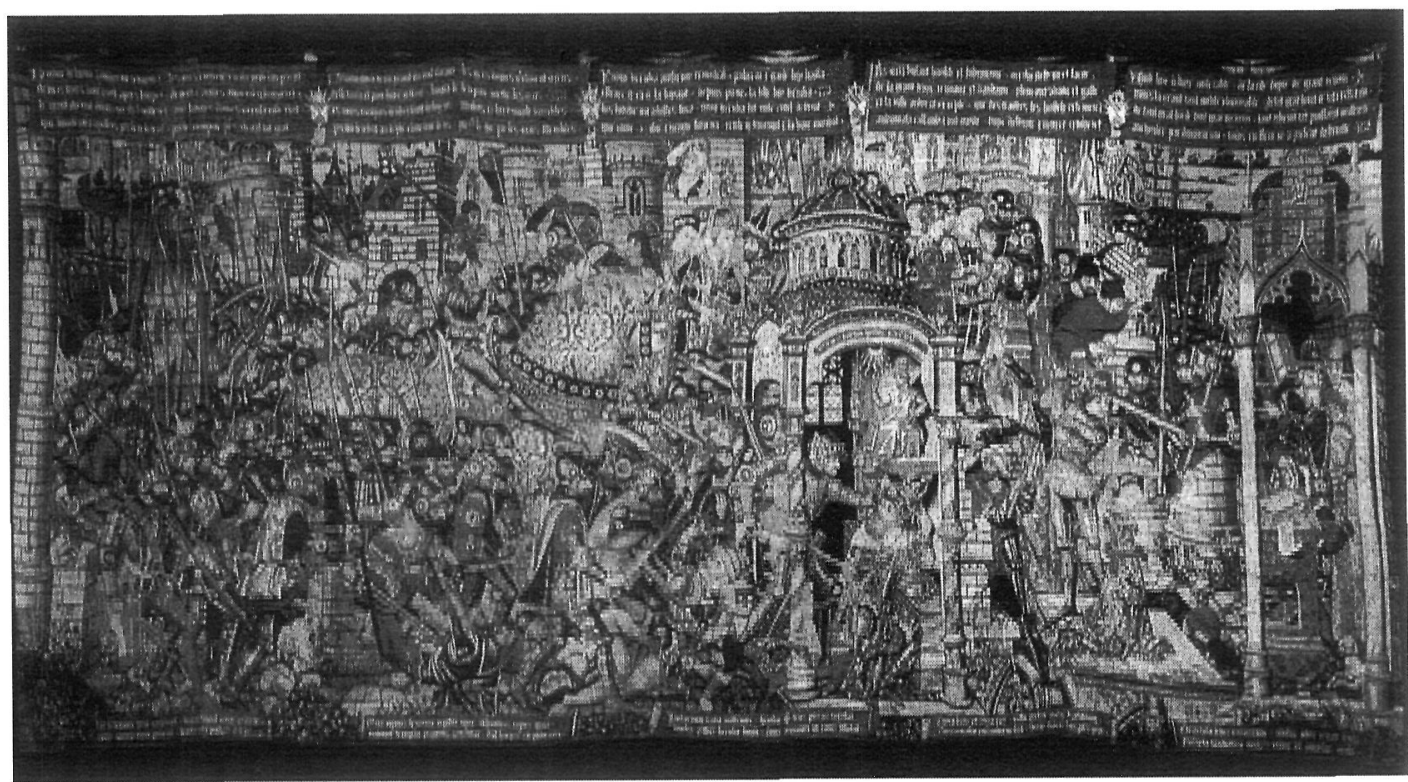

LÁMINA 4. Medidas: 9,42 metros largo x 4,77 metros alto.

José Lezama Lima y la fundación imaginaria de la literatura colonial cubana 


\title{
EL ROMANCERO EN AMÉRICA Y LA TRADICIÓN CUBANA
}

\author{
AURELIO GONZÁLEZ
}

1

Ramón Menéndez Pidal, Romancero hispánico, $2^{a}$ ed., EspasaCalpe, Madrid, 1968, p. 226.

2

Véase Alejo Carpentier, La música en Cuba, Fondo de Cultura Económica, México, 1972, pp. 21-22. [ [ ${ }^{9}$ ed. 1946]

3

Bernal Díaz del Castillo, Historia verdadera de la conquista de la Nueva España, ed. de Carmelo Sáenz de Santa María, Patria, México, 1983, capítulo 36
El romancero en América y la tradición cubana

AURELIO GONZÁLEZ

\section{NOTICIA Y RECOLECCIÓN DEL ROMANCERO EN AMÉRICA}

Menéndez Pidal considera que "podemos decir con seguridad que un copioso romancero pasó a América en la memoria de aquellos que tripulaban las naves descubridoras y en el recuerdo de cuantos después allá fueron» ${ }^{1}$. El género romancístico acompaña a los navegantes, misioneros, exploradores, soldados y funcionarios al Nuevo Mundo como parte de su bagaje cultural tradicional pues los versos de los romances reflejan los valores de su comunidad, además de contener historias fascinantes y ejemplos de vida desde el mundo de la ficción. Además, los hombres y mujeres que los cantan lo hacen de manera natural, con la tranquilidad del saber no aprendido.

En su primer viaje Colón desembarcó en Cuba en 1492, esperando encontrar el palacio del Gran Khan; no lo halló, pero en poco tiempo, la isla fue el punto de pasaje obligado para el avance al nuevo mundo; la colonización de la isla comenzó realmente en 1512, cuando el capitán español Diego Velázquez de Cuéllar fundó la ciudad de Baracoa en la costa oriental de la isla. Posteriormente fundaría otros asentamientos importantes, como Bayamo, Santiago de Cuba en 1514 y La Habana en 1515 que convirtieron a Cuba en la base de abastecimiento para las expediciones a México y la Florida. En esas ciudades es seguro que se oirían cantar los romances en las faenas de trabajo o en las reuniones de soldados y aventureros en las cuales se recordarían las hazañas que contaban los ciclos épicos y caballerescos de estas baladas que son los romances.

Porras, cantor, Alonso Morón, vihuelista, y Ortiz, el músico, soldados que formaron parte de la expedición de Cortés a México, primero se asentaron en Cuba, concretamente en Bayamo y Trinidad, y es natural, por la importancia y valoración que tenía en esa época el género, que entre los textos que formaban su repertorio se hayan contado los romances, tanto aquellos famosos que estaban en boga como algunos otros tal vez oídos en su niñez. Este repertorio seguramente lo cantaron durante su estancia en Cuba pues ahí se dedicaron a la actividad musical ${ }^{2}$.

Al hablar del Romancero en América es un lugar común mencionar el diálogo entre Hernán Cortés y Alonso Hernández Puertocarrero - salidos de Cuba en 1518 - frente a la isla de San Juan de Ulúa, en las costas de la que llamarían Nueva España, en el cual ambos emplean versos de romance, uno con los de Montesinos que se inicia

Cata Francia, Montesinos, cata París, la ciudad, cata las aguas de Duero, do van a dar en la mar;

y la respuesta con los del romance de Gaiferos:

denos Dios ventura en armas como al paladín Roldán;

diálogo que relata vivamente en su crónica Bernal Díaz del Castillo . El episodio retrata perfectamente la forma en que el Romancero estaba arraigado en la expresión coloquial de los hombres del siglo XVI ya que en ese momento la cultura tradicional está plenamente vigente y posee una dinámica que le permite acompañar al hombre en todas sus actividades, no sólo en el momento de la reunión o la fiesta o el trabajo, y ello es válido aun en el nuevo ámbito apenas conocido de esa tierra sorpren- 
dente y maravillosa que es América. Esta consideración sigue siendo válida aunque el diálogo no se haya llevado a cabo en esa forma y pueda ser simplemente un recurso literario de Bernal, en cuyo caso implicaría que él efectivamente conocía los romances sin ser un hombre de letras y que para sus receptores era absolutamente verosímil un diálogo de ese tipo.

También se cuenta en esta crónica de la conquista de Nueva España que cuando Cortés llora en Tacuba la muerte de algunos de sus hombres, el bachiller Alonso Pérez al tratar de consolarlo hace referencia al romance que empieza:

\section{Mira Nero de Tarpeya \\ a Roma cómo se ardiá;}

Los testimonios sobre la presencia de Romancero en el continente recién descubierto se remontan al mencionado de 1519 y son frecuentes a lo largo de todo el siglo. Otros cronistas, además de Bernal Díaz del Castillo, como Fernández de Oviedo (en su Historia general de las Indias nos dice a propósito del naufrago Alonso Zuazo en 1524: «Buenas las traemos, señor, pues que venimos acá»), Pedro Cieza de León (a propósito del complot de Gonzalo Pizarro contra Almagro en 1537: «Tiempo es, el caballero, tiempo es de andar de aquí») y Diego Fernández Palencia (con motivo de la derrota que infligió el rebelde Hernández Girón a las tropas reales en la batalla de Chuquinga, Perú, en 1554: «no van a pie los romeros, que en buenos caballos van»). Todos ellos nos proporcionan testimonios de la presencia del Romancero en América en los primeros tiempos del descubrimiento y la Conquista en el lenguaje coloquial. Desde luego esto no excluye la vida del romance en sí mismo como historias que se escuchan con placer, como cuenta Pedro Gutiérrez de Santa Clara que hizo Francisco de Carvajal en 1547 cuando, hallándose enfermo, pidió que le cantaran «el romance de Gaiferos o las coplas del Marqués de Mantua»5.

Por otra parte, la llegada de cancionerillos, pliegos sueltos y romanceros también está documentada ${ }^{6}$ ya a lo largo de todo el siglo XVI. La difusión del Romancero por medio de la imprenta, al proporcionar un soporte escrito permanente, dinamiza las innovaciones y funciona como un refuerzo de los textos tradicionales y juglarescos viejos.
En América se afincará ese transmisor -en realidad no importa mucho que sea un clérigo misionero, un bachiller letrado, un soldado o un simple hidalgo o villano en busca de fortuna- que es poseedor de una cultura tradicional y un espíritu juglaresco que le permite refuncionalizar y adaptar las historias de los romances a su nuevo contexto social e ideológico, lo mismo que transformar las acciones y los hechos cotidianos de la Conquista en materia literaria, tal como sucedía en España ${ }^{7}$. No se trata ahora de refundiciones sino de creaciones y recreaciones que pueden darse en un ámbito culto, pero también correr el abierto espacio de la tradición oral, como por ejemplo:

\section{En Tacuba está Cortés con su escuadrón esforzado; triste estaba y muy penoso, triste y con muy gran cuidado, la una mano en la mejilla y la otra en el costado.}

En otros casos tal vez pueda tratarse de romances al modo culto, con un espíritu más bien cronístico o erudito, lo cual explicaría en algunos momentos la falta de vuelo poético tanto culto como incluso tradicional. El Romancero se afinca en el Nuevo Mundo y así es que encontramos huellas de la presencia del Romancero tradicional y también del artificioso Romancero nuevo tan en boga en la época gracias al impulso de Lope, Góngora o Liñán de Ria$\mathrm{za}$, en autores cultos novohispanos como Fernán González de Eslava quien en el último cuarto del siglo XVI (muere hacia 1603) cita o contrahace hasta treinta romances nuevos y viejos en sus Coloquios espirituales y sacramentales, destacando la «Ensalada de San Miguel $»^{8}$ en la que, entre otros, utiliza versos de El prisionero, El infante vengador, Virgilios, Roncesvalles, etc., los cuales necesariamente debían de ser del dominio común pues de lo contrario no se justificaría su utilización en una ensalada alegre ante un público multirracial y popular?.

Por otra parte, así como el hombre europeo se acomodó a las condiciones climáticas y nuevas estructuras sociales que le planteaba el nuevo continente y dio lugar a una descendencia americana, también el Romancero se integró a la cultura americana, modificando muchos de sus aspectos y generando manifestaciones innovadoras propias de la nueva cultura.

En este transplante a tierras americanas, merced a la apertura propia del género, el romance se enriquece con términos nuevos, secuencias narrativas, formas particulares, etc.,
4 Bernal Díaz de Castillo, op. cit., cap. 145

\section{5}

Véase Emilia Romero, El romance tradicional en el Perú, El Colegio de México, México, 1952, pp. 14-16.

6

Véase Irving Leonard, Los libros del conquistador, Fondo de Cultura Económica, México, 1953, pp. 110-111. Por ejemplo, en el pagaré de 1576 de Alfonso Losa, mercader de libros, de la Ciudad de México, constan "unos Romances viejos, papelones a 4 reales», p. 286.

7

Sobre el Romancero y el tema de la Conquista puede verse mi artículo: Aurelio González, "Los romances de la Conquista: enfoques y perspectivas», en Relaciones literarias entre América $y$ España en los siglos XVI y XVII, Universidad Autónoma de Ciudad Juárez, México, 1992, pp. 211-224.

\section{8}

Fernán González de Eslava, Villancicos, romances, ensaladas y otras canciones devotas, ed. de Margit Frenk, El Colegio de México, México, 1989, pp. 229232

\section{9}

Cf. Margit Frenk, «Romances y villancicos en la Nueva España del siglo XVI (El testimonio de González de Eslava), en E. Rodríguez Cepeda (ed.), Actas del Congreso Romancero Cancionero UCLA (1984), Porrúa Turanzas, Madrid, 1990, †. II, p. 332.
El romancero en América y la tradición cubana

AURELIO GONZÁLEZ 
10

Véase en el número monográfico sobre Literatura popular. Conceptos, argumentos, temas coordinado por María Cruz García de Enterría, mi artículo «La tradición del Romancero en América», Anthropos, 166-167 (1995), pp. 145-147.

11

Manuel da Costa Fontes, Romanceiro Português do Canadá, Universidade Coimbra, Coimbra, 1979.

12

Véase Ramón Menéndez Pidal, "Las primeras noticias de romances tradicionales en América y especialmente en Colombia", Homenaje a Enrique José Varona, Dirección de Cultura de la Secretaría de Educación, La Habana, 1935, pp. 23-27. Publicado originalmente en la Revista Cubana, 1-1 (1935), pp. 12-13.

13

"La poesía popular en la América del Sur», Revista de Archivos Bibliotecas y Museos, 6 (1902), pp. $43-49$.

\section{4}

«Los romances tradicionales de América», Cultura Española, 1906, pp. 72-111. Reeditada en forma definitiva en Los romances de América y otros estudios, Espasa-Calpe, Madrid, 1939, (Austral, 55)

15

Julio Vicuña Cifuentes, Romances populares y vulgares recogidos de la tradición oral chilena, Imprenta Barcelona, Santiago de Chile, 1912

\section{6}

Raquel Barros y Manuel Dannemann, El Romancero chileno, Universidad de Chile, Santiago, 1970.

El romancero en América y la tradición cubana

AURELIO GONZÁLEZ al tiempo que permite que en algunos casos el texto deje de ser un romance y se convierta, por ejemplo, en un corrido, nuevo género americano, hijo del romance tradicional oral y del romance vulgar de pliego y nieto de la balada europea, que en México desplaza en vitalidad al propio romance.

Después del periodo colonial nos encontramos con otros fenómenos y así hay que entender también que en la América independiente, después del período de la ruptura con España, hay un momento posterior en que se percibe que el verdadero peligro es la aculturación proveniente del ámbito estadounidense y se trata de rescatar una forma de tradición de tipo hispánico. En este sentido el Romanticismo había traído consigo el redescubrimiento de la tradición romancística española de origen medieval, misma que, por ejemplo en México, Argentina y otros países de América también fue conocida por los autores liberales y conservadores a través de los románticos españoles.

En general, en muchas de las obras de estos autores a lo largo y ancho del continente americano aparecen presencias, a través de temas, formas, motivos, etc. de la literatura tradicional, podríamos decir que, por una motivación de tipo ideológico relacionada con la creación de una cultura nacional, en ese momento del siglo XIX coexisten las dos formas culturales, pero es evidente la distancia que tenían con respecto a un auténtico conocimiento de la literatura del pueblo.

Hoy en día los testimonios de la presencia del Romancero en América abarcan desde la pampa argentina hasta las pequeñas poblaciones de las zonas desérticas del sur de Estados Unidos y las poblaciones costeras de Terranova en Canadá; su presencia se detecta en las pequeñas poblaciones serranas y en núcleos urbanos de relativa importancia de México, Perú, Colombia, Venezuela o Brasil, se le encuentra en la tierra firme y en las islas de Cuba, Puerto Rico o la Dominicana y es más vital en las poblaciones del interior que en las costas, que parecen preferir la canción lírica, tal como sucede en la tradición peninsular ibérica ${ }^{10}$.

Independientemente del flujo de emigrantes españoles y portugueses a lo largo de quinientos años, la tradición americana se ha enriquecido en las últimas décadas con la emigración portuguesa, en especial de las Azores, al Canadá y a los Estados Unidos (tradición recogida primero por Joanne Purcell,
1968, y después por Manuel da Costa Fontes ${ }^{11}$, 1979,1980 y 1983 en ambos países) y el desplazamiento de sefarditas orientales o del Norte de África, a raíz de la II Guerra Mundial, a estos mismos países (Canadá: Oro AnahoryLibrowicz, 1988, Estados Unidos: Samuel G. Armistead y Joseph Silverman) y a algunos de habla española como la Argentina, y desde luego la emigración española por motivos económicos de las dos primeras décadas del siglo de asturianos y gallegos a Cuba, México y la Argentina, el exilio republicano a raíz de la Guerra Civil en 1939 y los primeros años 40, así como de emigrantes canarios a Venezuela en la última migración en los años sesenta.

Se calcula que el corpus romancístico de la tradición oral moderna americana que se ha recogido está integrado por más de 2.200 versiones de unos cincuenta romances. En el descubrimiento en América de la tradición oral moderna romancística tuvo mucho que ver, como en tantas otras cosas relacionadas con el Romancero, Ramón Menéndez Pidal, en esta ocasión con su viaje a América en 1905 como comisario especial para llevar a cabo los trabajos preparatorios del laudo que había de emitir el rey de España sobre los límites en conflicto entre Perú y Ecuador. Por otra parte la primera noticia moderna sobre el Romancero en América la proporciona el filólogo colombiano Rufino José Cuervo en 1874, en el Anwario de la Academia Colombiana, donde menciona haber oído cantar a «un inculto campesino... en un desconocido valle de los Andes» ${ }^{12}$ romances de Bernardo del Carpio y de los siete infantes de Lara, aunque sin proporcionar ningún texto. Las primeras versiones de la tradición oral moderna americana fueron dadas a conocer en 1902 por Ciro Bayo en la Revista de Archivos, Bibliotecas y Museos $^{13}$, se trata de versiones recogidas en Argentina (o en Bolivia) de Las señas del esposo y del Conde Olinos. Mismas que más tarde (1905) publicaría en Quito Menéndez Pidal en un pliego suelto y el propio Bayo en su Romancerillo del Plata (Victoriano Suárez, Madrid, 1913).

Posterior a la recolección de Menéndez Pidal de $1905^{14}$ destaca la muestra de Chile publicada por Julio Vicuña Cifuentes ${ }^{15}$ (1912) que incluye romances tradicionales y vulgares. En 1970, Raquel Barros y Manuel Dannemann ${ }^{16}$, darán a conocer una nueva colección de versiones chilenas. Para Argentina, después del trabajo de Bayo destaca la obra de 
Juan Alfonso Carrizo ${ }^{17}$ realizada en la región del Tucumán (provincias de Jujuy, Salta, La Rioja y Catamarca) entre 1926 y 1942 recogiendo romances, coplas, décimas, glosas y todo tipo de estrofas. Posteriormente han recogido romances Juan Draghi (1938), Ismael Moya (1941) a través de las encuestas del magisterio, Isabel Aretz-Thiele (1946) y más recientemente (1996) Gloria Chicote ${ }^{18}$. En los Estados Unidos la tradición romancística está presente en los Estados del sur donde la presencia española y mexicana fue más intensa donde la han recogido Aurelio M. Espinosa (1925-1953) en California ${ }^{19}$ y Nuevo Méxi$\mathrm{co}^{20}$, Arthur L. Campa ${ }^{21}$ (1946) en Nuevo México, Américo Paredes ${ }^{22}$ (1953) en Tejas y Samuel G. Armistead ${ }^{23}$ (1978-1983) en Luisiana. También se han hecho recolecciones entre las comunidades sefardíes de Nueva York y Seattle. La primera recolección en México se debe a Pedro Henríquez Ureña y Bertram Wolfe (1925), posteriormente Vicente T. Mendoza hace su magno trabajo de relación entre el corrido y el romance ${ }^{24}$ (1939), y en 1986 Mercedes Díaz Roig y Aurelio González ${ }^{25}$ editan la suma total de lo publicado así como el resultado de su trabajo de campo. En Puerto Rico trabajó María Cadilla ${ }^{26}$ (1940); en Venezuela: R. Olivares Figueroa (1944-1948), Ramón e Isabel Aretz (1961) y Pilar Almoina ${ }^{27}$ (1975); República Dominicana: Henríquez Ureña ${ }^{28}$ (1913), Edna Garrido29 (1946); Uruguay: Marina López Blanquet (1946), Ildefonso Pereda ${ }^{30}$ (1947); Nicaragua: Ernesto Mejía Sánchez $^{31}$ (1946); Perú: Emilia Romero (1952); Guatemala: Carlos Navarrete ${ }^{32}$ (1963); Colombia: Gisela Beutler'33 (1969); Brasil: Rossini Tavares de Lima (1971), Jackson Da Silva Lima (1971), Braulio do Nascimento (1974), José Aloisio Vilela (1983); Costa Rica: Michele Cruz Sáenz ${ }^{34}$ (1986). La recolección en Cuba la encabeza Carolina Poncet (1914) y José María Chacón (1914-1922), en los últimos años se recogieron materiales debido a iniciativas oficiales y de algunos investigadores como Feijoo; recientemente Beatriz Mariscal ${ }^{35}$ ha publicado en México una recopilación de lo editado y de fondos archivísticos. Una valiosa visión global de la tradición romancística americana, recogida a lo largo de casi setenta años, se puede conocer a través de la antología que preparó Mercedes Díaz Roig y publicada póstumamente $(1990)^{36}$. No hay publicaciones de Honduras, Paraguay ${ }^{37}$ y Bo-

livia (en este último país la duda estaría en una de las versiones de Ciro Bayo, primero ubicada en Bolivia y después en Argentina).

\section{EL CORPUS DEL ROMANCERO EN AMÉRICA}

Los principales temas del corpus del Romancero recogido en América son los siguientes ${ }^{38}$ :

Novelescos (la estructura familiar)

Adulterio: La adúltera, Bernal Francés, $L a$ malcasada.

Relaciones prematrimoniales: La bastarda $y$ del segador, Gerineldo, La mala yerba, El caballero berido, *Polonia, La dama y el pastor.

Habilidad de la mujer: La doncella guerrera, Rico Franco, Blancaflor y Filomena, *La condesita, *El caballero burlado.

17

Juan Alfonso Carrizo, Cancionero popular de Salta Baiocco, Buenos Aires, 1933; Cancionero popular de Jujuy, Universidad, Nacional de Tucumán, Tucumán, 1934; Cancionero popular de Tucumán, 2 vols., Espasa-Calpe, Buenos Aires, 1937 y Cancionero popular de La Rioja, 3 vols., Espasa Calpe, Buenos Aires, 1942.

\section{8}

Gloria Chicote y Miguel A. García, Romances. Poesía oral de la Provincia de Buenos Aires, Universidad Nacional de La Plata, Buenos Aires, 1996.

\section{9}

Aurelio M. Espinosa, «Romances tradicionales en California», en Homenaje a Menéndez Pidal, Hernando, Madrid, 1925, t. I, pp. 299-313.

20

Aurelio M. Espinosa, Romancero de Nuevo Méjico, Consejo Superior de Investigaciones Científicas, Madrid, 1953, (Anejos de la Revista de Filología Española, 58).

21

Arthur L. Campa, Spanish Folkpoetry in New Mexico, The University of New Mexico Press, Albuquerque, 1946.
22

Américo Paredes, A Texas-Mexican Cancionero, Folksongs of the Lower Border, University of Illinois Press, Urbana, 1976.

23

Samuel G. Armistead, "Romances tradicionales entre los hispanoahablantes del Estado de Luisiana», Nueva Revista de Filología Hispánica, 27 (1978), pp. 39-56 y «Más romances de Luisiana», Nueva Revista de Filología Hispánica, 32 (1983), pp. 41-54.

\section{4}

Vicente T. Mendoza, Romance español y corrido mexicano, Universidad Nacional Autónoma de México, México, 1939.

\section{5}

Mercedes Díaz Roig y Aurelio González, Romancero tradicional de México, Universidad Nacional Autónoma de México, México, 1986.

\section{6}

María, Cadilla, Juegos y canciones infantiles de Puerto Rico, Baldrich, San Juan, 1940.

\section{7}

Pilar Almoina de Carrera, Diez Romances hispánicos de la tradición oral venezolana, Universidad Central de Venezuela, Caracas, 1975.
28

Pedro Henríquez Ureña, «Romances en América", Cuba Contemporánea, 3 (1913), pp. 347 366.

29

Edna, Garrido de Boggs, Versiones dominicanas de romances españoles, Pol Hnos., Santo Domingo, 1946.

30

Ildefonso Pereda Valdés, Cancionero popular uruguayo, Floresa y Lafón, Montevideo, 1947.

31

Ernesto Mejía Sánchez, Romances y corridos nicaragüenses, Imprenta Universitaria, México, 1946.

32

Carlos Navarrete, "El romance tradicional y el corrido en Guatemala», Universidad de San Carlos, 59 (1963), 181-254.

\section{3}

Gisela Beutler, Estudios sobre el Romancero español en Colombia, Instituto Caro y Cuervo, Bogotá, 1977.

34

Michele Cruz Sáenz, Romancero tradicional de Costa Rica, Juan de la Cuesta, Newark, 1986.

35

Beatriz Mariscal, Romancero general de Cuba, El Colegio de México, México, 1996

36

Mercedes Díaz Roig, Romancero tradicional de América, El Colegio de México, México, 1990.

37

En 1982 Germán Granda publica fragmentos de Gerineldo y Alfonso XII en «El Romancero tradicional español en Paraguay. Razón de una (aparente) anomalia», Thesaurus, Boletín del Instituto Caro y Cuervo, 37 (1982), pp. 118-146.

38

El asterisco (*) antes del fítulo indica que el tema generalmente no se encuentra autónomo y el punto $(\bullet)$ que sólo se han encontrado pervivencias fragmentarias.

El romancero en América y la tradición cubana

AURELIO GONZÁLEZ 
El acervo infantil puede incluir otros textos que hemos clasificado temáticamente como Delgadina, Santa Catalina o Alfonso XII.

40

M. Díaz Roig, Romancero tradicional de América, op. cit. p. 322.

41

Merle E. Simmons, A Bibliography of the «Romance» and Related Forms in Spanish America, Indiana University Press, Bloomington, 1963

42

Ana Valenciano, «El Romancero tradicional en la América de habla hispana», Anales de Literatura Hispanoamericana, 21 (1992), pp. 146-163
El romancero en América y la tradición cubana

AURELIO GONZÁLEZ
Prueba de fidelidad: ¿Cómo no cantáis, la bella?, Las señas del esposo, $\bullet$ La difunta pleiteada

Incesto: Delgadina, Silvana, •Amnón y Tamar

Amores desdichados: La aparición de la amada difunta, Alfonso XII, - El quintado, Conde Olinos, $\bullet$ La muerte ocultada, La mala suegra, $\bullet$ Misa de amor, $\bullet$ Conde Alarcos Forzadores y seductores: Blancaflor y Filomena, Rico Franco, El conde preso, $\bullet E l$ marinero raptor, La molinera y el cura Cautivos: La hermana cautiva, El prisionero, Las tres cautivas

Religiosos

La buisqueda de la Virgen, El marinero, Santa Catalina, Santa Elena, La Virgen y el ciego, La buenaventura de Cristo, Santa Bárbara, Madre, a la puerta bay un niño, La Virgen romera, $\bullet$ El robo del Sacramento

REFERENTES HISTÓRICOS (pervivencia novelesca)

La muerte de Prim, La muerte del principe don Juan, $\bullet$ El duque de Alba

\section{INFANTILES}

Carabi, Don Gato, Las hijas de Merino, Hilitos de Oro, Mambrú, Las tres cautivas, Monja a la fuerz $a^{39}$

Mercedes Díaz Roig nos presenta en 1990 la siguiente síntesis de la presencia romancística de la tradición americana ${ }^{40}$ :

\begin{tabular}{lcc}
\hline & Romances & Versiones \\
\hline Argentina & 28 & 323 \\
Cuba & 25 & 116 \\
Puerto Rico & 23 & 97 \\
Venezuela & 22 & 171 \\
Dominicana & 21 & 116 \\
Chile & 20 & 137 \\
Colombia & 20 & 197 \\
Uruguay & 19 & 87 \\
México & 16 & 188 \\
Estados Unidos & 13 & 141 \\
Costa Rica & 11 & 54 \\
Nicaragua & 11 & 43 \\
Guatemala & 10 & 26 \\
Perú & 8 & 38 \\
Panamá & 5 & 10 \\
Ecuador & 2 & 2 \\
El Salvador & 1 & 3 \\
\hline
\end{tabular}

Fuente fundamental para el conocimiento del Romancero en América sigue siendo el trabajo bibliográficoi de Merle E. Simmons ${ }^{41}$. El objeto de este amplio, cuidadoso y útil trabajo es, en palabras de su autor, llenar una carencia bibliográfica de México y la mayor parte de Hispanoamérica (exceptúa Chile y Argentina). Simmons pone como límite muy amplio a su recopilación el romance y todas las formas derivadas, no sólo métricamente, de éste. La bibliografía, formada por 2,108 referencias, comprende un apartado general y 19 divisiones que corresponden a los países hispanoamericanos (agrupando Argentina y Uruguay bajo el rubro de Río de la Plata, e incluyendo a Estados Unidos en México). Las referencias cubren una gran cantidad de temas, algunos relacionados sólo en forma muy relativa o lejana con la tradición o la poesía popular, por ejemplo las fichas sobre los sefardíes en la zona del Pacífico de Estados Unidos o sobre autores cultos del siglo XIX. Algunos de los muchos aspectos que cubre este trabajo son la música; fuentes antiguas de textos; obras literarias (novelas, teatro, etc.) y autores cultos que utilizan el romance; reseñas de trabajos; artículos en periódicos; la tradición sefardí; bibliografías; textos diversos que contienen romances o corridos como las crónicas de la Conquista; pliegos sueltos y colecciones de éstos.

\section{TRANSFORMACIONES DEL RO- MANCERO EN AMÉRICA}

Como ha dicho Ana Valenciano, para determinar las variantes más significativas de la tradición del Romancero en América es necesario:

[...] comparar las versiones de cada tema en particular con las del resto de las tradiciones del Romancero pan-hispánico. Pero, antes de enfrentarse con esta labor, conviene separar los textos amañados o de probable origen libresco, y distinguir aquellas actualizaciones, por lo general recientemente importadas, que no han sufrido modificación alguna y por ello no se han incorporado al acervo literario de la tradición autóctona $a^{42}$.

También es conveniente recordar que, a pesar de que muchas veces se ha querido ver en la literatura tradicional y popular «la expresión del alma del pueblo», como ya dijo 
Menéndez Pelayo, no haya nada menos nacional que el folclor. Por otra parte en el ámbito del Romancero la tradición americana no ha sido muy creativa en cuanto a temas, ya que mantiene los comunes, tal vez pudiéramos pensar en creaciones locales en temas como Román Castillo en México. Sin embargo, sí podemos hablar de una unidad de la tradición americana, Carrizo ${ }^{43}$ lo explica recordando la simultaneidad de la Conquista, unidad de religión, lengua, leyes (esto durante el periodo colonial), comercio y difusión de los mismo libros, a lo cual habría que añadir la emigración que también ha mantenido constantes (por ejemplo predominancia de gallegos y asturianos en el siglo XIX).

Los cambios son de muy diverso tipo, los más inmediatos están en la adaptación léxica al contexto, incluyendo topónimos, por ejemplo este final de Delgadina está absolutamente cubanizado, hecho «criollo», con la inclusión de los plátanos maduros:

Angerina se murió en un cuarto muy oscuro y por velas le pusieron cuatro plátanos maduros ${ }^{44}$.

Tenemos versiones mexicanas de este mismo romance que hablan del padre incestuoso como «rey de Morelia», o las versiones de La bastarda que la convierten en «hija del presidente de Chile» en vez de ser sobrina del $\mathrm{Pa}$ pa o el Emperador como sucede en la tradición española.

Esta versión de La mala yerba recogida en Puerto Rico también se ha adaptado al contexto:

- Coja esta criaturita pa el capitán de La Habana; si encontrare a mi padre, por Dios no le diga nada, que éstas son almendras verdes pa el capitán de

$\left[\mathrm{La} \mathrm{Habana}{ }^{45}\right.$.

También hay variación en aspectos más profundos temáticos o estructurales como por ejemplo algunas versiones cubanas, peruanas y colombianas han eliminado el tema del incesto en Delgadina y lo han reemplazado por otros motivos como la desobediencia o el enamoramiento ${ }^{46}$. En versiones sudamericanas de Blancaflor y Filomena la terrible venganza de Blancaflor ha quedado en un simple malparto. En otros casos pueden ser adiciones como el episodio introductorio que justifica la presencia del marido en
Bernal Francés que aparece en versiones mexicanas y centroamericanas, o el duelo final entre el esposo y el amante en versiones del sur de Estados Unidos, Venezuela y Dominicana de La adúltera. También es distinto el final de las versiones estadounidenses y mexicanas de La dama y el pastor ya que estas tradiciones han añadido un episodio en el cual el pastor desdeñoso finalmente requiere de amores a la dama la cual se niega. También es propio de la tradición romancística en América el cruce de Delgadina con Silvana o de Elmarinero con El barco santo o con Santa Catalina.

Pero las transformaciones también pueden ser de otro tipo y llegar hasta la creación de nuevos géneros como el corrido. En este sentido para Vicente T. Mendoza ${ }^{47}$ la forma de poesía narrativa más difundida en México durante la Colonia fue el romance o corrido andaluz, sobre todo en la región del Centro y en los Estados de Guerrero, Jalisco, México, Michoacán, Oaxaca y Puebla, en los cuales adoptó el nombre de corrido aunque popularmente también suele recibir otros nombres como: romance, tragedia, ejemplo, versos, coplas, «relación». No hay que olvidar que el vocablo corrido se emplea con diferentes acepciones en distintos lugares de habla hispana (al analizar el corrido mexicano generalmente se acepta que el término «es de origen musical y de nacionalidad española», pues en Andalucía se llama así a los romances cantados sin interrupción alguna) como Argentina, Chile, Filipinas y México. El corrido mexicano existe como una forma poética viva, obviamente además de México, en las comunidades hispanohablantes de Estados Unidos (Tejas, California, Nuevo México o Luisiana) o en Centroamérica, especialmente en Guatemala.

En otro lugar he afirmado ${ }^{48}$ el origen hispano del género y señalado que el corrido, como su antecesor el romance, en sus inicios tuvo un marcado carácter épico y «conforme va diluyéndose el espíritu propio de la época revolucionaria» se inclinó a los temas novelescos aunado a ello el influjo del romance vulgar de pliego suelto u hoja volante en el aspecto temático y en algunos elementos formales.

Samuel Armistead ${ }^{49}$ siguiendo el principio de que en cualquier lugar donde se hable español, portugués o catalán se pueden hallar
43

Cf. Juan Alfonso Carrizo, Antecedentes hispano-medievales de la poesía tradicional argentina, Estudios Hispánicos, Buenos Aires, 1945, cap. I.

44

A. Carpentier, op. cit., p. 35.

45

Aurelio M. Espinosa, «Romances de Puerto Rico», Revue Hispanique, 43 (1918), p. 332-333.

46

Mercedes Díaz Roig, «El romance en América» en Historia de la Literatura Hispanoamericana, Madrid, Cátedra, 1982, t. I, pp. 301-316.

47

Vicente T. Mendoza, El romance español y el corrido mexicano. Estudio comparativo, Universidad Nacional Autónoma de México, México, 1939, pp. 115118.

48

Aurelio González, «¿Cómo vive el corrido mexicano? ¿̇Quién canta corridos? ¿Quiénes cantaron corridos?», Caravelle, 51 (1988), pp. 23-30.

49

Samuel G. Armistead, «Hispanic Traditional Poetry in Lovisiana», en Antonio Sánchez Romeralo, Diego Catalán y Samuel G. Armistead, eds., El Romancero hoy: nuevas fronteras, Segundo Coloquio Internacional sobre el Romancero, Gredos-Seminario Menéndez Pidal, Madrid, 1979, pp. 147-158.

El romancero en América y la tradición cubana

AURELIO GONZÁLEZ 
Américo Paredes, «El concepto de la 'médula emotiva' aplicado al corrido mexicano Benjamín Argumedo", Folklore Americano, XIX/XX-17 (1971-1972), pp. $139-175$

51

Tristam P. Coffin, «Mary Hamilton and the Anglo-American Ballad as an Art Form", Journal of American Folklore, 70 (1957), pp. 208-214.

52

Carolina Poncet y de Cárdenas, «El romance en Cuba», Revista de la Facultad de Letras y Ciencias, 18 (1914), pp. 180-260 y 278-321.

\section{3}

José María Chacón y Calvo, «Romances tradicionales. Contribución al estudio del folklore cubano", Ensayos de literatura cubana, Saturnino Calleja, Madrid, 1922, pp. 83-186. Publicado originalmente en la Revista de la Facultad de Letras y Ciencias, 18 (1914), pp. 45-121. También «Nuevos romances en Cuba», Revista Bimestre Cubana, 9 (1914), pp. 199-210.

\section{4}

Sofía Córdova de Fernández, «El folklore del niño cubano», Revista de la facultad de Letras y Ciencias, 33 (1923), pp. 268306; 34 (1924), pp. 26-52; 35 (1925), pp. $109-156$ y 361418. También publicó materiales en Archivos del Folklore Cubano de 1925 a 1929.

55

William Milwitzky, «El viajero filólogo y la antigua España», Cuba y América, XIX-17 (1905), pp. 307-309 y 325-327.

56

Ana María Arissó, Estudios del folklore sagüero, Instituto de $\mathrm{Se}$ gunda Enseñanza Sagua la Grande, La Habana, 1940.

57

Concepción T. Alzola, Folklore del niño cubano, Universidad Central de Las Villas, Santa Clara, 1961.

58

Nicolás Farray, «Romances y cantares españoles en la tradi-

El romancero en América y la tradición cubana

AURELIO GONZÁLEZ

romances, realizó una investigación en el Estado de Luisiana, Estados Unidos, en dos comunidades hispanas, en las que la mayoría de sus habitantes son pescadores descendientes de emigrantes de las Islas Canarias, entre 1975 y 1976, y recogió varios ejemplos de romances, «décimas», corridos, leyendas, etc. En esa región el género más común de poesía narrativa es el que ellos llaman «décima»: una forma de canción (coplas octosilábicas asonantadas, menos narrativa que el corrido) emparentada con el romance y similar, en estructura y estilo al corrido y que se refiere a los acontecimientos locales, problemas a los que se enfrentan los pescadores, sátiras políticas, historias de animales marinos fantásticos, etc. y considera al corrido, origen de la «décima». Los romances hallados son el reflejo de la supervivencia de la tradición oral hispánica y la existencia de la «décima» demuestra la originalidad y creatividad colectiva y actual en la poesía de tradición oral hispánica a partir del Romancero.

Por su parte Américo Paredes ${ }^{50}$ plantea que una posibilidad de cambio de los textos de tradición oral que se da en la zona americana que él estudia —alejada de la corriente romántica de considerar que el canto folclórico surge en la creación de la danza colectiva y de estimar como más antiguas y valiosas las versiones de cantos (baladas, romances) que en unos pocos versos trazan una situación dramática-, que se apoya en el concepto de «médula emotiva» (emotional core) postulado por Tristram P. Coffin ${ }^{51}$, entre otros, y así, cada balada o romance tiene una médula emotiva esencialmente lírica que prevalece sobre las partes narrativas, en forma tal que a menudo la canción pasa del género narrativo al puramente lírico, tal como sucede con romances y corridos de la región norteamericana fronteriza.

ción cubana», Carlos Magis (ed.), Actas del Tercer Congreso Internacional de Hispanistas, El Colegio de México, México, 1970, pp. 331-344.

59

Mirta Aguirre, "El romance en Cuba y en otros países latino- americanos", Islas, 51 (1975), pp. $217-235$.

60

Susana Redondo de Feldman «Romances viejos en la tradición popular cubana», Revista Hispánica Moderna, 31 (1965), pp. 365-372.

\section{LA TRADICIÓN CUBANA}

En la tradición cubana se encuentran algunos romances considerados como raros en el acervo romancístico americano, entre ellos $\mathrm{La}$ muerte del principe don Juan (pequeño fragmento), El conde Grifos Lombardo, Rico Franco, La mala suegra, Santa Elena, El caballero berido, La muerte de Prim o Silvana (reducido a unos cuantos versos integrados a Delgadina). Aunque este romancero, como en la mayor parte de los países hispanoamericanos, no ha sido suficientemente recogido ni estudiado.

La época de mayor florecimiento de la recolección de romances en Cuba hay que situarla en las primeras dos décadas de este siglo a partir de la publicación del artículo de Carolina Poncet sobre el romance en Cuba ${ }^{52}$ que recogía su trabajo presentado como tesis doctoral un par de años antes. Al trabajo de Poncet siguieron las recolecciones y artículos entusiastas de José María Chacón y Calvo $\left(1914,1922,1925\right.$ y 1926) ${ }^{53}$, Sofía Córdova de Fernández (1925-1929) ${ }^{54}$, con especial atención al romancero infantil, y en menor medida de Carlos A. Castellanos (1920). El primer texto romancístico de la tradición oral moderna cubana fue recogido por William Milwitky ${ }^{55}$ en 1905, después recogieron versiones aisladas José Antonio Fernández de Castro (1923), Emilio Portell Vila Cárdenas (1926), Aurelio M. Espinosa (1930) y Aníbal Otero (1933). En 1940 Ana María Arissó56 recoge textos en Sagua la Grande (en ese entonces provincia de Las Villas), posteriormente Concepción T. Alzola (1954 y 1961) ${ }^{57}$ estudia el folclore infantil y en ese marco recoge versiones de romances. La publicación, póstuma y en forma coleccionada en 1985 a cargo de Mirta Aguirre, de los trabajos de Carolina Poncet $y$, en un apéndice, de los materiales de su archivo personal permitió el acceso a nuevos textos que la investigadora no había dado a conocer en su momento. Por otra parte en distintos artículos se han dado a conocer algunas otras versiones recogidas contemporáneamente por investigadores como, Nicolás Farray $(1967)^{58}$, Mirta Aguirre $(1975)^{59}$ y Susana Redondo de Feldman $(1985)^{60}$, además de las recolecciones, al parecer bastante amplias, hechas para el Atlas de la cultura popular tradicional cubana que se encuentran depositadas y aún inéditas en 
el Centro de Investigaciones «Juan Marine1lo». Casi todos los textos publicados y otros provenientes del Archivo Menéndez Pidal y del archivo de Chacón y Calvo han sido reunidos en el ya citado Romancero general de Cuba preparado en México por Beatriz Mariscal ${ }^{61}$.

Podemos hablar que en la tradición cubana se conocen hasta 40 temas romancísticos, aunque Mercedes Díaz Roig62 los limita a 25 manteniendo algunos que pueden ser discutibles como Mi hijo se ha casado, sin antecedentes peninsulares y que puede ser una canción narrativa como Las bijas de Merino o Carabi

La distribución de versiones por provincias es la siguiente ${ }^{63}$ :

\begin{tabular}{|c|c|}
\hline La Habana & $\begin{array}{l}28 \text { versiones (La Habana 24, } \\
\text { Santa María del Rosario } \\
\text { 3, Marianao 1) }\end{array}$ \\
\hline Santiago de Cuba & 15 versiones \\
\hline Camagüey & 14 versiones \\
\hline Villa Clara & $\begin{array}{l}14 \text { versiones (Sagua la Grande 11, } \\
\text { Santa Clara 2, Regla 1) }\end{array}$ \\
\hline Matanzas & $\begin{array}{l}8 \text { versiones (Matanzas 7, } \\
\text { Cárdenas 1) }\end{array}$ \\
\hline Guantánamo & $\begin{array}{l}5 \text { versiones (Baracoa 1, } \\
\text { Patana Arriba 4) }\end{array}$ \\
\hline Sancti Spiritu & 2 Versiones (Trinidad 2) \\
\hline Cienfuegos & $\begin{array}{l}2 \text { versiones (Cienfuegos } 1 \text {, } \\
\text { Villa Clara } 1 \text { ) }\end{array}$ \\
\hline Oriente ${ }^{64}$ & 1 versión \\
\hline sin lugar & 48 versiones \\
\hline Total & 137 versiones \\
\hline
\end{tabular}

Por los datos que tenemos la dispersión geográfica es amplia y están representadas nueve de las catorce provincias actuales. La parte que aparentemente no está estudiada (cabría la posibilidad, aunque es muy remota, que alguna de las versiones que no indican el lugar fuera de esta región) es la zona occidental, provincia de Pinar del Río. Aunque no aparecen versiones de Las Tunas, Holguín, Ciego de Ávila y Granma la zona sí ha sido tocada. Por otra parte es evidente que las encuestas no han sido sistemáticas salvo la de la tradición sagüera realizada por Arissó en 1940. La abundancia de versiones habaneras se explica casi por una cuestión de simple localización de los investigadores en la capital.

Beatriz Mariscal considera características del romancero cubano el predominio de los temas adaptados a los juegos y corros infantiles y el carácter urbano, así como la presencia lexicalizada de romances eruditos de origen libresco como Roncesvalles (versión recogida en 1928 por Aurelio Espinosa $)^{65}$. Carolina Poncet consideraba que el romance tenía poco auge en Cuba por la predilección popular por la copla lírica, así como por la estrofa más cadenciosa y rica en consonantes de tema amoroso «pueril y quejumbroso» ${ }^{66}$. Los textos recogidos por Farray en el 67 nos muestra que aún en zonas rurales alejadas como la región de Maisí se conserva la tradición del romancero infantil.

Los temas romancísticos que se han recogido en Cuba son los siguientes: El conde Grifos Lombardo (1), Delgadina (9), Silvana (1), La hermana cautiva (3), El conde Niño (Conde Olinos) (7), La malcasada (5), La mala suegra (1), Monja a la fuerza (7), Hilitos de oro (Escogiendo novia) (6), Las hijas de Merino (4), Carabi (5), Mambrú (5), Don Gato (2), Mi bijo se ha casado (1), La dama y el pastor (1), Gerineldo (1)+ La condesita (2), Rico Franco (Isabel) (9), La adúltera (Albaniña) (6), La molinera y el cura (1), Las señas del esposo (12), Madre, Francisco no viene (1), La muerte del principe don Juan (1), Polonia y la muerte del galán (4), Mal de amores (No me entierren en sagrado) (2), Mina el desesperado (7), La aparición (1), Alfonso XII (4), La muerte de Prim (6), Marinero al agua (1), El marinero raptor (1), Roncesvalles (1), Santa Elena (1), Santa Catalina (11) ${ }^{67}$, Santa Bárbara (1), La Virgen romera (1), Madre, a la puerta bay un niño (1), La Virgen y el ciego (1), Por el rastro de la sangre (3), Por aquel postigo, a lo divino, (La Virgen vestida de colorado) (1), ¿Cómo no cantáis la bella?, a lo divino (1).

La presencia del romancero en América ha provocado en distintos países y en distintos momentos diferentes valoraciones o maneras de entenderlo, en ocasiones apasionadas y carentes absolutamente de valor científico, sin embargo, es evidente por estos planteamientos la importancia que tiene en la manera en que se trata de entender la tradición oral, la cultura tradicional y popular para la creación de una identidad nacional, así en México el romance fue núcleo de divergencias en relación con el corrido ya que si bien Vicente T. Mendoza y otros autores señalaban, sin desconocer sus innovaciones y peculiaridades, la clara
61

La autora incluye además los textos recogidos por Carolina Poncet de Dominga Martínez, natural de Entrepeñas, Zamora, y con poquísimo tiempo de residencia en Cuba que publicó como material distinto de la tradición cubana en el «Romancerillo de Entrepeñas y Villar de los Pisones", Révue Hispanique, 57 (1923), pp. 286-314.

62

M. Díaz Roig, Romancero tradicional de América, op. cit., p. 318.

63

A partir de 1976, con la nueva Constitución, Cuba quedó dividida en 14 provincias, que substituyen a las anteriores seis, y por el municipio especial de la isla de la Juventud. Las provincias son: Camagüey, Ciego de Ávila, Cienfuegos, Ciudad de La Habana, Granma, Guantánamo, Holguín, La Habana, Las Tunas, Matanzas, Pinar del Río, Sancti Spiritus, Santiago de Cuba y Villa Clara.

64

La antigua provincia de Oriente hoy en día está dividida en Las Tunas, Holguín, Guantánamo, Granma y Santiago de Cuba. Esta versión fue recogida por Aníbal Otero en El Bollo, Orense, España en 1933 y enviada a Menéndez Pidal.

65

Aurelio M. Espinosa «El tema de Roncesvalles y Bernardo del Carpio en la poesía popular de $\mathrm{Cu}$ ba", Archivos de Folklore Cubano, V-3 (1930), pp. 193-198.

66

Carolina Poncet, «El romance en Cuba», en Investigaciones y apuntes literarios», sel. y pról. Mirta Aguirre, Letras Cubanas, La Habana, 1985, pp. 15-16.

67

Incluyo la versión publicada por Carpentier en La música en Cuba, op. cit., pp. 33-34 no recogida por Beatriz Mariscal en su Romancero general de Cuba.

El romancero en América y la tradición cubana

AURELIO GONZÁLEZ 
Celedonio Serrano Martínez, El corrido mexicano no deriva del romance español, Centro Cultural Guerrerense, México, 1963.

\section{9}

Américo Paredes, «El folklore de los grupos mexicanos en Estados Unidos», Folklore Americano, XIV-14 (1966), pp. 146-163.

\section{0}

Años después será el propio Carpentier quien muestre accidentalmente al recibir en Venezuela unos cuadernos de música que dicha pretendida música precolonial no era más que la música del romance de Don Gato del siglo XVIII.

71

A. Carpentier, La música en Cuba, op. cit., p. 303.

72

Ibid, pp. 32-33.
El romancero en América y la tradición cubana

AURELIO GONZÁLEZ filiación del corrido con respecto al romance hispánico, hubo otros que plantearon desatinos totales como Celedonio Serrano ${ }^{68}$ con su peregrina afirmación nacionalista de que el corrido mexicano no deriva del romance español. Este autor impugna las teorías de Vicente T. Mendoza - y de sus seguidores- sobre el origen hispánico del corrido y defiende apasionadamente el carácter autóctono del género (al cual le señala, más que poco convincentemente, como antecedente directo la antigua poesía náhuatl) sin dejar de reconocer cierta influencia de la poesía tradicional española en la polimetría, el poliestrofismo y la rima varia que caracterizan al corrido. En algún momento esta corriente tuvo seguidores como Mario Colín aunque de forma mucho más matizada.

Con respecto a la tradición hispánica en los Estados Unidos, Américo Paredes ${ }^{69}$ señala que es frecuente referirse al folclor mexicano y al del "México de afuera» (núcleos mexicanos en Estados Unidos) como a dos entidades relacionadas pero distintas, y que entre los folcloristas norteamericanos hay tres grandes corrientes que valoran esas diferencias: la «españolista» (que resalta la «pureza» del folclor méxico-americano), la «difusionista» (que considera al folclor mexicano como la fuente creativa) y la «regionalista» (que concibe al folclor mexicano como «nacional», en tanto que el del «México de afuera» se cataloga como una de tantas regiones folclóricas norteamericanas). Por su parte $\mathrm{Pa}$ redes considera que el choque de pueblos y culturas es el factor principal al cual se deben los rasgos originales del folclor méxico-americano y ejemplifica esta originalidad con el corrido fronterizo (que, según Paredes, surgió antes que el corrido mexicano), canciones satíricas, leyendas, cuentos y juegos infantiles.

En el caso de Cuba el romance también se encontró en medio de diversos planteamientos polémicos sobre la construcción de una identidad nacional. En los años veinte, siguiendo las propuestas de Fernando Ortiz y el grupo del «minorismo", cobra fuerza una línea de reivindicación del elemento negro en la cultura cubana a pesar del rechazo de muchos sectores de la sociedad cubana. Para otros sectores la oposición se da en el sentido que plantean que por nacional se debe entender algo anterior a la conquista española, esto es; el ele- mento indio. Esta posición la encabezan musicólogos como Sánchez de Fuentes, que, sin bases, toman como bandera el Areito de Anacaona ${ }^{70}$.

Sin embargo, la oposición básica se da entre lo «afrocubano» y lo «guajiro»en cuanto a la constitución de una identidad popular. En este sentido Alejo Carpentier dice, a propósito del transmisor guajiro - en contraposición con la creatividad que encuentra en la música mestiza o negra-, que aunque el guajiro es muy poeta:

[...] ciñe su invención poética a un patrón melódico tradicional, que hunde sus raíces en el romance hispánico [...] No crea melodías. En toda la isla, canta sus décimas sobre diez o doce patrones fijos, muy semejantes unos a otros, cuyas fuentes primeras pueden hallarse en cualquier romancero tradicional de Extremadura ${ }^{71}$.

Unos años después, en la década de los cuarenta, el mismo Carpentier reconoce el peso que tiene el elemento hispánico en la conformación de la tradición americana y en este sentido señala el peso que tiene el Romancero y considera que uno de los países de América que mejor han conservado la tradición del romance es Cuba:

El romance heredado, cantado sobre las cunas, transmitido de boca en boca. Muchos conquistadores eran analfabetos. Otros, en cambio, sabían cantar y versar [...] Lo cierto era que, letrados o no, traían toda una tradición poética y musical a bordo de sus carabelas, como lo demuestra la casi increíble propagación de la Delgadina, cuya presencia se ha revelado en los más remotos confines del continente americano [...] con variantes más o menos acentuadas -en las palabras, en la melodía, o en ambas - pero con persistencia de la idea central ${ }^{72}$.

En la Cuba en el siglo XX, así como González de Eslava en el México del siglo XVI, también encontramos autores cultos que emplean los romances en sus textos, ejemplo de ellos es Alejo Carpentier quien desde luego no se limitó al romance, más bien podríamos decir que éste fue minoritario en relación con las canciones y rituales afrocubanos, los sones y coplas líricas. En Los pasos perdidos (1953) Carpentier retuerce los versos del romance de El caballero burlado de la siguiente forma: 
Soy hijo del rey Mulato

y de la reina Mulatina;

la que conmigo casara

mulata se tornaría ${ }^{73}$.

No hay que olvidar que en su caso el uso de cantos y canciones, "aunque con excepciones, la intención de su presencia y la función que desempeñan es generalmente de crítica, sátira o ataque, y para lograr tales propósitos Carpentier no retrocede ante el anacronismo ${ }^{74}$.

Con respecto a las versiones cubanas del romancero tradicional recogido de la memoria comunitaria cubana en algunos casos éstas se mantienen muy próximas a la tradición peninsular, como en la siguiente versión habanera de Santa Catalina:

En Galicia hay una niña, que Catalina se llama. Todos los días de fiesta, su madre la castigaba porque no quería hacer lo que su padre mandaba y mandó hacer una rueda de cuchillos y navajas, y en medio de la rueda a Catalina arrodillaba.

Y bajó un ángel del cielo a salvar a Catalina.

-Sube, sube Catalina, que el Rey de los Cielos te llama ${ }^{75}$.

En muchos casos las versiones de la tradición oral cubana tienen la influencia de la tradición escrita, ya sea la de Flor nueva de $\mathrm{Me}$ néndez Pidal o de otros cancioneros y romanceros. En muchos casos se conserva el carácter narrativo, la tendencia al diálogo, y por la influencia musical se da la repetición del último hemistiquio y la inclusión de interjecciones y expresiones como: $A y$, ay, ay o tralá, lalá $\hat{a}^{76}$.

En la tradición cubana encontramos también muchas versiones «vulgata» como las de La bermana cautiva que derivadas de un arreglo moderno en España empiezan con versos similares a «el día de los torneos pasé por la morería». En Cuba estos han variado así:

Señores, voy a contarles la historia de una niñita que cautivaron los moros a los ricos de Melilla.

$$
\text { RGC, } 70^{77}
$$

Al salir de Casablanca, cerca de una morería había una mora lavando en una fuente cristalina.

$$
\text { RGC, } 71
$$

Ayer tarde en los torneos pasé por la morería, hallé una mora lavando al pie de una fuente fría. RGC, 69
Por el contrario, las versiones del Conde Olinos (Conde Niño) de la tradición de Cuba se apegan a la subtradición extremeña que mantiene la forma de mayor antigüedad.

En otros aspectos sigue los mismo fenómenos que se dan en España y otras regiones de América, así el romance de Gerineldo se encuentra en versiones autónomas y en versiones dobles con el romance de La condesita (que en forma autónoma sólo se ha recogido una versión argentina), aunque según Mercedes Díaz Roig las versiones combinadas de estos dos romances escasean en el panorama americano dos de las tres versiones cubanas continúan con La condesita y la otra cierra la historia con los primeros versos de dicho romance:

Ya se ha formado una guerra entre España y Portugal, y nombran a Gerineldo por capitán general.

(RGC, 128)

La tradición cubana también posee textos que no tienen antecedentes peninsulares como el romancillo hexasilábico Mi hijo se ha casado. En esto coincide con otras tradiciones romancísticas hispanoamericanas que han generado textos propios, como la mexicana con Román Castillo.

El motivo viajero «No me entierren en sagrado» aparece en tres textos diferentes, por lo general convertido en elemento nuclear, los temas son: Mina el desesperado, Mal de amores, El caballero herido y Polonia.

En el aspecto léxico el rasgo más característico es la abundancia de diminutivos, por ejemplo, en las versiones cubanas de Delgadina encontramos hijitas, chiquirritica, vasito, padrecito, criadita, casadita, poquita, papaíto, mamaíta, muertecita.

Por otra parte desde el siglo pasado se documentan pervivencias de temas y motivos de romances en distintos tipo de composiciones como por ejemplo «guarachas» que conservan referencias al romance de Don Gato o de Mambrú.

La tradición cubana del Romancero, como la tradición americana en general, vive sometida a las fuerzas que caracterizan la literatura tradicional, esto es: oscila entre la conservación y la variación. Así por un lado hay versiones que en poco se diferencian de las españolas y en cambio hay otras que siguen nuevos derroteros, pero todas ellas lo que muestran es un
Alejo Carpentier, Los pasos perdidos, en Obras completas, Siglo XXI, México, 1987, t. II, p. 360 .

74

Emma Susana Sperati-Piñero, "Cantos y canciones en la obra de Carpentier», Nueva Revista de Filología Hispánica, 35 (1987), p. 529.

\section{5}

Recogida poco antes de 1945 por Alejo Carpentier y publicada en La música en Cuba, op. cit., p. 232.

76

Cf. Tony Évora, Orígenes de la música cubana. Los amores de las cuerdas y el tambor, Alianza, Madrid, 1997, pp. 38-39.

77

Cito siguiendo la edición del Romancero general de Cuba, op. cit. indicando el número de página. 
proceso de adaptación a la realidad americana (en la cual viven como cosa natural, no ajena), realidad a la cual deben su conservación pues, al tratarse de textos de transmisión oral, si la comunidad los ha conservado en su memoria es que de manera propositiva le dicen algo pertinente acerca de su sistema de valores.

Un estudio más profundo del Romancero americano nos permitirá por un lado com- prender mejor otras formas literarias de gran arraigo que se derivan de este género (corridos, décimas, coplas, guarachas), por otra ver los mecanismos de variación y conservación a lo largo de siglos y, finalmente, situar adecuadamente la tradición americana y local de cada país o región en la cultura general del mundo hispánico o ibérico. 
Catedrático de Literatura Hispanoamericana en la Universidad de Alicante. Ha publicado numerosos estudios y ediciones sobre autores y movimientos literarios españoles e hispanoamericanos, entre ellos, Miguel Hernández, Pablo Neruda, José María Arguedas, poesía novohispana, Ilustración e Inquisición en América, refle-

\title{
SIGLO XVII: ECOS DE LA ÉPICA Y LA ARCADIA ITALIANA EN CUBA: ESPEJO DE PACIENCIA DE SILVESTRE DE BALBOA
} xiones en torno a la identidad cultural, etc. En la actualidad ha centrado sus investigaciones en la literatura del período colonial hispanoamericano.

\author{
JOSÉ CARLOS ROVIRA
}

Hay un párrafo de José Lezama Lima con el que inicio, que es un fragmento de su Introducción a un sistema poético ${ }^{1}$, y dice así: «Está dispuesto José Martí, y es ésa su imago más fascinante junto con su muerte, a llenar el contenido vacío de ese espejo de paciencia». La idea de Lezama Lima me pareció bastante intensa: José Martí llenando el espejo de paciencia y, por tanto, trazando, a partir de aquí, la posibilidad de una lectura independentista de un texto colonial, del texto cubano colonial por excelencia.

Espejo de paciencia no fue contemporáneo de los cubanos del siglo XVII, en cuyos comienzos se escribió, puesto que no pudieron conocerlo, pero empezó a ser contemporáneo de los cubanos del siglo XIX. No quiero decir por supuesto que los cubanos del siglo XIX, y tampoco los del XX, se volcaran con fruición sobre este texto de comienzos del XVII. Lo que sí que afirmo es que la obra de Balboa ha permitido desde su descubrimiento una reflexión fundacional, cumplida con creces en nuestro siglo.

\section{HISTORIA CRÍTICA DE ESPEJO DE PA- CIENCIA}

La conservación de la obra se debe a una copia del obispo Pedro Agustín Morell de Santa Cruz, quien en 1760 introduce el texto en su Historia de la isla y catedral de Cuba. El manuscrito de Morell fue utilizado años después por José Antonio Echeverría quien en la revista El Plantel publica en 1838 varios frag-

mentos de la obra, habiendo dado el codirector de la misma Ramón Palma la primera noticia de Espejo en $1837^{2}$.

La primera edición del texto es la de Carlos M. Trelles en el interior de su Bibliografía cubana de los siglos XVII y XVIII en 1927. Al año siguiente es reimpreso por José Manuel Carbonell en su Evolución de la cultura cubana. En 1941 se realiza una edición acompañada de un estudio crítico de Felipe Pichardo Moya. En 1960 Cintio Vitier lo edita con una interesante propuesta crítica sobre la obra, repitiendo en 1962 la edición con algunas variaciones (facsímil del manuscrito del obispo Morell). En 1970 aparece la edición de Ángel Aparicio en Miami, y en 1981 aparece la de Lázaro Santana en Las Palmas, reeditándose en 1988. El texto que vamos a utilizar aquí es el de esta edición de $1988^{3}$.

La reflexión crítica principal comienza con el estudio de Pichardo Moya ${ }^{4}$, al que siguen las contribuciones próximas de Cintio Vitier y de José Lezama Lima. Desde el ámbito académico son sobresalientes los estudios de Roberto González Echevarría ${ }^{5}$ Ivan Shulmann ${ }^{6}$ y el más reciente de Juana Goergen. También el del editor Lázaro Santana. A estos estudios haré referencia más adelante.

1

José Lezama Lima Confluencias, Selección y prólogo de Abel E. Prieto, La Habana, Editorial Letras Cubanas, 1988, pág. 334.
2

Sigo básicamente en esta nota de fuentes a Juana Goergen, Literatura fundacional ameri cana: el Espejo de paciencia, Madrid, Ed. Pliegos, 1993, y a
Cintio Vitier, «Espejo de paciencia», Crítica cubana, La Habana, Ed. Letras Cubanas, 1988, págs. 245-277.

3

Silvestre de Balboa, Espejo de paciencia, ed. de Lázaro Santana, Las Palmas, Biblioteca básica canaria, 1988.

4.

El estudio de Felipe Pichardo Moya ("Estudio crítico», por Felipe Pichardo Moya, que prologa la edición de Espejo, La Habana, Cuadernos de Cultura, 1941) ha sido abundantemente utilizado con posterioridad por el establecimiento minucioso de las fuentes literarias que asume Balboa.

5

Roberto González Echevarría, «Reflexiones sobre Espejo de paciencia de Silvestre de Balboa, Nueva revista de filología hispánica, 1977, 35:2, págs. 571590.

6

Iván A. Schulman, «Espejo/ Speculum: el Espejo de paciencia de Silvestre de Balboa», Nueva revista de filología hispánica, 1988, 36:1, págs. 391-406.
Siglo XVII: ecos de la épica y la arcadia italiana en Cuba: Espejo de paciencia de Silvestre de Balboa JOSÉ CARLOS ROVIRA 


\section{SILVESTRE DE BALBOA}

Balboa nació en Las Palmas de Gran Canaria el 30 de junio de 1563. Debió pasar a Cuba entre 1593 y 1603 , fechas que surgen de deducciones de documentos inquisitoriales concernientes a un hermano suyo. Habitó en Puerto Príncipe y en Bayamo, siendo en la primera ciudad donde desempeñó su puesto de Escribano del Cabildo. Su muerte debió acaecer en Puerto Príncipe antes de 1644, año en que su mujer Catalina de la Coba otorgó testamento en el que se hace constar que su marido Silvestre había fallecido. El hecho de que llegara a Cuba a los treinta años plantea su formación canaria previa, lo que ha sido puesto de manifiesto por Lázaro Santana pudiendo tener esto, como veremos, una gran relevancia para su obra.

\section{EL POEMA}

La primera página del poema (título y dedicatoria) reza así:

\section{Espejo de paciencia}

Donde se cuenta la prisión que el capitán Gilberto Girón hizo de la persona del ilustrísimo señor don fray Juan de las Cabezas Altamirano, obispo de la isla de Cuba, en el puerto de Manzanillo, año de mil seiscientos cuatro.

Dirigido al mismo señor obispo

por Silvestre de Balboa Ttroya y Quesada, natural de la isla de Gran Canaria, vecino de la villa del Puerto Príncipe.

Sigue a esta página un prohemio «Al Lector» y una Carta-dedicatoria al obispo Fray Juan de las Cabezas Altamirano, fechada en Puerto del Príncipe el 30 de julio de 1608.

Continúan seis sonetos de presentación de la obra realizados por personas principales de Puerto Príncipe.

Siguen dos cantos, construidos mediante octavas reales, el primero de 560 versos (558 pues faltan dos) y el segundo de 654 , concluido con un motete de 45 versos (37 en octosilábicos formando cuartetas y una octava real de clausura). Cada canto está precedido por el argumento.

\section{EL ARGUMENTO}

Siglo XVII: ecos de la épica y la arcadia italiana en Cuba: Espejo de paciencia de Silvestre de Balboa JOSÉ CARLOS ROVIRA puerto de Bayamo tiene noticias de que el obispo Fray Juan de las Cabezas Altamirano está en Yara y con veintiséis soldados se dirige por la noche a Yara y coge preso al obispo y canónigo Puebla, llevándolos a su nave, donde consiguen la libertad a cambio de cueros y dinero que dan las gentes de Bayamo. El canto primero acaba con un saludo mitológico y de la naturaleza al obispo.

El canto segundo comienza con la decisión de vengar la afrenta por parte del capitán español Ramos y los habitantes de Bayamo. Reúne veinticuatro de los mismos y ataca a Gilberto Girón y sus hombres. En el combate el negro Salvador da muerte al francés del que se corta la cabeza llevándola a Bayamo. Un motete octosilábico concluye el poema cantando la hazaña del capitán Ramos y los habitantes de Bayamo.

Esta es la historia.

\section{ACERCA DEL VALOR DE LA OBRA}

La Imago ha participado entre nosotros a través de un libro de contenido escaso y pobrísimo [...] Comenzar una literatura con un título de tan milenario refinamiento como Espejo de paciencia, título que menos que un esqueleto nos regala una nadería, nos sobresalta y acampa, nos maravilla y aguarda. Pero supongamos que la obra alcanzase una calidad tan refinada y misteriosa, tan secular y tan contemporánea como la que su enigmático título nos sugiere...

$$
\text { José Lezama Lima }
$$

Sonreiría quizá José Lezama Lima la primera vez que leyera el comienzo del poema de Silvestre de Balboa:

\section{Canten los unos el terror y espanto}

Que causó en Troya el Paladión preñado:

Celebren otros la prisión y el llanto

De Angélica y el Orco enamorado:

Que yo en mis versos sólo escribo y canto

La prisión de un Obispo consagrado:

Tan justo, tan benévolo y tan quisto

Que debe ser el sucesor de Cristo.

$$
(\mathrm{I}, 1-8)
$$

Sonreiría seguramente el poeta Lezama ante esta épica a lo divino de alguien que conocía de oídas a Torcuato Tasso y había leído Las lágrimas de Angélica de Luis Barahona de Soto. Conocía también La Araucana de Alonso de Ercilla, y su negación de un espacio que tu- 
vo en la épica renacentista la referencia esencial del Orlando furioso de Ariosto.

Veamos el comienzo del Orlando de Ariosto:

Le donne, i cavallier, l'arme, gli amori,

le cortesie, l'audaci imprese io canto,

Sigamos con la negación inicial de Ercilla:

No las damas, amor, no gentilezas

de caballeros canto enamorados;

ni las muestras, regalos y ternezas

de amorosos efectos y cuidados;

mas el valor, los hechos, las proezas

de aquellos españoles esforzados,

que a la cerviz de Arauco no domada

pusieron duro yugo por la espada.

Aunque la negación esencial que está estableciendo con seguridad procede de la afirmación primera de Torcuato Tasso en su Gerusalemne Liberata:

Canto l'arme pietose él capitano

che'l gran sepolcro liberò di Cristo.

Molto egli oprò co 1 senno e con la mano,

molto soffrì nel glorioso acquisto,

por la coincidencia de los espacios de rima, en la que el italiano adquisto (consecución) se transforma en el castellano e irregular quisto, «querido», como manera de rima y para realzar con su canto al obispo Altamirano.

Sabemos a partir de aquí la dificultosa aventura épica, tan plagada de fuentes conocidas, en la que se encontró el poeta Silvestre de Balboa: el canto al cautiverio y liberación del obispo Altamirano se nutrió de una trabajosa versificación en la que no es difícil desalentarse a pesar de sus valores (es un problema general de la épica renacentista, aunque aquí se agrava).

Sin embargo, algunos valores hay que señalar...

\section{EN UN LUGAR DE LA ARCADIA LLA- MADO BAYAMO}

El obispo Altamirano, antes de su rapto, estaba bastante bien en Bayamo, mientras el capitán pirata se encontraba en Manzanillo, preparándolo. Los versos de Balboa nos preparan a nosotros para el acontecimiento:
Cesen en Dido, basten en Prïamo

De sus ojos la líquida corriente,

Que nuestra Troya es hoy Bayamo,

Humeando a impulsos de traición ardiente.

$(\mathrm{I}, 57-61)$

Quizá el pequeño puerto o la pequeña marina de Manzanillo se había convertido en 1604 en el enclave principal no sólo de una piratería europea, sino de una teoría de la misma piratería. Nos sigue contando Balboa:

Aquí del Anglia, Flandes y Bretaña

A tomar vienen puerto en su marina

Muchos navíos a trocar por cueros

Sedas y paños y a llevar dineros.

(I, 69-72)

Pero no solamente estaban allí los piratas trocando cueros, sedas y paños por dineros, sino que inevitablemente había un conjunto de divinidades clásicas que debían servir de entorno necesario a la historia que Balboa iba a narrar.

Surgen aquestas naos a una playa

Que tiene al Sur, llamada Manzanilla,

Donde Eufrosina, Erato, Clío y Aglaya

Algún tiempo tuvieron cetro y silla.

(I, 73-76)

Dos de las tres gracias (Eufrosina y Aglaya) y dos musas, Erato, la de la poesía, y Clío, la de la historia, tuvieron cetro y silla, en Manzanilla por supuesto. Las necesidades de la rima van articulando el tono narrativo del poema, que alcanza su límite divertido cuando nos dice (para seguir rimando):

Mientras duró este trato dio de Acaya

Un mal olor que inficionó su orilla:

Y hay desde ella al Bayamo, villa sana,

Diez leguas y una más, por tierra llana.

(I, 77-80)

¿Acaya? No conozco ninguna Acaya en Cuba, y parece que no existe, por lo que el aire que «inficionó» la orilla de Manzanilla parece que procedía de la Acaya del Peloponeso. Balboa era efectivamente bastante leído, hasta el punto de que a partir de aquí iba a
Siglo XVII: ecos de la épica y la arcadia italiana en Cuba: Espejo de paciencia de Silvestre de Balboa JOSÉ CARLOS ROVIRA 
fundar una Arcadia en Bayamo, como ya han establecido algunos críticos:

Estaba a la sazón el buen prelado
En esta ilustre villa generosa,
Abundante de frutas y ganado,
Por sus flores alegre y deleitosa.
Era en el mes de Abril, cuando ya el prado
Se esmalta con el lirio y con la rosa,
Y están Favonio y Flora en su teatro;
Año de mil y un seis con cero y cuatro.

$$
(\mathrm{I}, 81-88)
$$

El regusto de modelos literarios nos salta enseguida en esta Bayamo "por sus flores alegre y deleitosa» y en este prado contiguo que «se esmalta con el lirio y con la rosa». La revelación crítica es el uso de una Arcadia, aquí urbana, Bayamo, o próxima a la misma, y por tanto, rural y campestre, en la que se va a desarrollar el argumento épico del rapto del obispo. En la Arcadia de Balboa van a convivir como en la de Sannazaro inmediatamente ninfas y sátiros con los humanos, a través de un modelo de mediación en el que con seguridad la Arcadia de Sannazaro es releída a través de Luis Barahona de Soto y sobre todo de la Égloga II de Garcilaso de la Vega que tiene versos de sobrado reconocimiento. Ya Felipe Pichardo Moya situó el origen del verso:

Y están Favonio y Flora en su teatro,

en Barahona de Soto (Égloga Primera, Octava XIX):

Y con su dulce soplar Favonio y Flora,

verso que repite casi exactamente Balboa:

Y con dulce soplar Favonio y Flora

Daban la vida a rosas y claveles,

$$
(\mathrm{I}, 147-48)
$$

en los Favonio (Céfiro, el viento) y Flora, la Primavera, crean la brisilla necesaria para una entrada arcádica de la que no está lejos Garcilaso y sus Églogas ( Cuando Favonio y Céfiro, soplando», dice Garcilaso en la III).

\section{NINFAS Y CAPROS EN EL TRÓPICO}

Siglo XVII: ecos de la épica y la arcadia italiana en Cuba: Espejo de paciencia de Silvestre de Balboa JOSÉ CARLOS ROVIRA

tamirano estaba en Yara cuando el pirata Gilberto Girón lo rapta, y estaba en mítica compañía:

Las hermosas oréades, dejando

el gobierno de selvas y montañas,

a Yara van alegres, y cazando

como suelen diversas alimañas

(I, 529-532)

pero estas ninfas de las montañas proceden de un universo literario anterior, directamente, reiterando versos y espacios de rima:

¡Oh hermosas oreadas que teniendo

el gobierno de selvas y montañas,

a caza andáis, por ellas discurriendo!

Dejad de perseguir las alimañas...

(Garcilaso, Égloga II, wv. 617-620),

como todo el cortejo renacentista que recorre el final del primer canto, canto de fusión de sátiros, faunos y silvanos con lenguajes de la naturaleza y el léxico cubano de la misma. Cuando el obispo consigue la libertad:

\section{Sálenle a recibir con regocijo \\ De aquellos montes por allí cercanos \\ Todos los semicapros del cortijo...}

(I, 473-475)

El cortejo se ordena llenándose de mitología europea y naturalezas cubanas: los sátiros, semicapros, faunos y silvanos le ofrecen guanábanas, gegiras y caimitos; las napeas le traen mameyes, piñas, tunas y aguacates, plátanos, mamones y tomates; las hermosas hamadríades que bajan de los árboles en «naguas» (otro cubanismo por enaguas) le ofrecen frutas de siguapas y macaguas, pitipayas, virijí y jaguas; luego ya las divinidades de los ríos, las náyades puras y garcilasianamente cristalinas, le traen peces y mariscos como jaguará, dajao y lisa, camarones, gujacas y guabinas; centauros y sagitarios le traen caza, mientras las oréades le traen iguanas, patos y jutías. Por último, aparece el "son de una templada sinfonía» en las que las flautas, zampoñas y rabeles se unen enseguida marugas, alborgues, tamboriles, tipinaguas y adufes, mientras los semicapros bailan con ninfas bellas, aunque no duda en advertirnos que las más bellas danzan con los centauros. Esta marimba tropical, cargada de mitología europea y ritmos caribeños es qui- 
zá uno de los momentos más brillantes del poema, al menos más divertidos en las aclamaciones de los centauros que danzan por el verde llano gritando «Viva nuestro pastor Altamirano». Por otro lado la presencia de un léxico de frutas, peces e instrumentos musicales da un nuevo rango a la significación cubana del poema del canario Balboa. Estamos otras vez, dirán algunos, ante un momento fundacional.

\section{ASPECTOS DE LA REALIDAD CUBANA}

Junto al aspecto ya señalado de la piratería, cuando el obispo ha sido liberado aparece un personaje vengador que, a las órdenes del capitán Ramos, lanza una certera lanzada al pirata Gilberto. Se trata del negro Salvador, con el que Balboa, tras contar su heroísmo certero, no duda primero en justificar su canto:

Ningún mordaz entienda ni presuma

Que es afición que tengo en lo que escribo

A un negro esclavo y sin razón cautivo,

$$
\text { (II, 406-408) }
$$

para terminar en cualquier caso pidiendo su libertad al pueblo de Bayamo:

Y tú, claro Bayamo peregrino,

Ostenta este blasón que te engrandece;

Y a este etiope de memoria dino,

Dale la libertad pues la merece.

$$
\text { (II, 409-412) }
$$

\section{¿UNA ACADEMIA EN BAYAMO?}

Algunos se plantearon el significado de los seis sonetos que preceden a la obra: un capitán, dos alféreces, el alcalde y el regidor y un «natural de Canarias» son sus autores. Algunos se han planteado la formación de Balboa en Canarias en el "Jardín délfico», academia o tertulia del poeta Cairasco, autor de El templo militante. El elogio a la isla, el elogio a Canarias, el elogio al obispo Altamirano y, sobre todo, desde el principio, el elogio a Silvestre de Balboa nutren una línea de interpretación de los sonetos en la que se ha querido ver en la villa de Bayamo un grupo activo de escritores aunque sólo sean conocidos por un soneto. pero sería discutible todo en cuanto que no lo podemos conocer. Se puede inventar un grupo activo en unos sonetos que a mí me dan

la impresión de que pueden ser del mismo autor, de Balboa, siguiendo una moda que probablemente el propio autor ha rastreado en una amplia tradición.

Por otra parte, algunos versos como:

Recibe de mi mano, buen Balboa,

Este soneto criollo de la tierra,

han sido leídos con la relevancia del término "soneto criollo», como que a través de él se está fundando una teoría diferencial de la poesía y del espacio histórico.

Es indudable la referencia a poema cubano que acompaña siempre a Espejo de paciencia. Ahora quiero plantear precisamente por eso alguna de las lecturas que el poema ha generado. Creo que la sorpresa por el título ha sido una de las constantes en la que han insistido algunos lectores ${ }^{7}$.

\section{LA IMAGEN REFLEJADA EN EL ESPEJO}

Este espejo cubano del siglo XVII, al margen de sus valores estéticos, sí tiene un valor esencial, provocativo, y es que, desde el siglo XIX, se ha ido llenando de imágenes. La idea es una reelaboración de Lezama, como sabemos, por el texto que cité al principio. ¿Qué imágenes han ido poblando el espejo? La de los sucesivos lectores que se aproximaron a él y quisieron fundar, quizá en un espejo bastante vacío, una lectura nacional y unos orígenes nacionales para una literatura ya en el siglo XVII.

Podríamos repasar alguno de estos reflejos. Tras las noticias del texto publicadas en 1838 por José Antonio Echevarría, el erudito Néstor Ponce de León publica en 1892 en la Revista Cubana una valoración del poema en la que introduce los siguientes criterios:

Considero este poema tanto más importante, cuanto que él sólo representa todo el movimiento literario de Cuba desde su conquista en 1511 hasta mediados del

\section{7}

Lezama ha insistido sobre la sorpresa del fítulo: «Al comenzar nuestra literatura un libro se brinda con un título de una fascinación mágica y severa. Es un título al que hay que buscarle par en la sabiduría china (Ting Fan So robando los me- locotones de la longevidad, Elogio de la poesía, El ave del paraíso se posa en una cascada), o en la gran secularidad que unía la fuerza medieval con la elegancia del flamígero - del curvo (Paráiso cerrado para muchos, Jardín abierto para pocos, Hospital de incu- rables, Recinto para cometas). Comenzar una literatura con un título de tan milenario refinamiento...», Introducción a un sistema poético, cf. Nota 1. Sin embargo no parece muy extraño el título que, en nuestra tradición, el Speculum medieval aparece asumiendo esta posibilidad, quizá literariamente desde Vincent de Beauvais, en su obra del siglo XIII Speculum majus, con sus espejos de naturaleza, sabiduría, moral $y$, finalmente, Espejo de la historia. En el siglo XVII he encontrado cincuenta y tantos espejos: por ejemplo Apologema, espejo y excelencias de la serafica religión de menores capuchinos de Fermin Rattariazi, en 1673; Archetypo de virtudes espejo de prelados el venerable fray. Francisco Ximénez de Pedro de Aranda Quintanilla y Mendoza en 1653; Claro espejo de religiosas de Luis Lozano en 1699; El buen pastor: espejo de curas y sacerdotes de Cristóbal Lozano en 1674; El espejo de la muerte: en que se notan los medios de prepararse para morir de Carlos Bundeto en 1700; Espejo de azero fino, en cuyos fondos briIlan sin azar los esplendores de Fernando Alfonso Escudero de la Torre en 1697; Espejo de christal fino y antorcha que abiva el alma de Pedro Espinosa en 1637; Espejo de curas, vilíssimo para todo genero de ecclesiásticos de Alonso de Vega en 1602; Espejo de disciplina regular de Santo Buenaventura en 1636 Espejo de la ivuentud moral politico y christiano de Marcos Bravo de la Serna, Marcos, Obispo de Chiapas en 1674; Espejo de la philosophía y compendio de toda la Medicina theórica de Juan de la Torre y Balcarcel en 1668; Espejo de perfección, para religiosas, y exercicio de virtudes de Bernardino Corvera en 1647; Espejo del alma christiana de Juan de Espinosa Salazar en 1657; Espejo en que se deve mirar el buen soldado ... de Juan Márquez Cabrera en 1664; Es pejo geográfico de Pedro Hurtado de Mendoza en 1691 Espejo mystico en que el hombre interior se mira ... de José de Nájara en 1672; y así hasta unos cincuenta más.

Siglo XVII: ecos de la épica y la arcadia italiana en Cuba: Espejo de paciencia de Silvestre de Balboa JOSÉ CARLOS ROVIRA 
Citado por Vitier, op. cit., págs. 252-53.

9

Ibídem, págs. 258-259

10

Alejo Carpentier, Concierto $\mathrm{Ba}$ rroco, La Habana, editorial Letras Cubanas, 1987, págs. 33 ss. siglo XVIII, es decir, 250 años, que a no existir ese poema presentarían el vacío más absoluto. Después de este gran esfuerzo, las musas cubanas cayeron de nuevo en profundo silencio; acaso no fue así, acaso se escribió mucho y probablemente muy malo, pero nada he podido encontrar desde $1608 . . .8$

La soledad del poema es la soledad misma de toda la tradición cubana. Ponce de León se situaba a fin de siglo ante la misma para redescubrir el valor esencial de un poema que por sí sólo configura toda una tradición. Y fue habitual reiterar durante años esas ideas cuando se afrontaba la obra de Balboa.

Fue José María Chacón y Calvo quien en 1913 crea un destacado reflejo nuevo en el poema de Balboa. Ya Cintio Vitier llamó la atención sobre la evocación que realizaba sobre «el grupo literario de Puerto Príncipe», tras destrozar sistemáticamente el valor literario del poema, pero afirmando que:

Podemos imaginarnos, a través de estos versos, la pequeña tertulia literaria de Balboa. Son sus amigos hombres de armas, que tienen a su cuidado la vigilancia de la villa. No son muchos sus trabajos; cuando han pasado los temores al corsario, se entregan a sus recuerdos. Silvestre de Balboa, muchas noches, en las chozas de tierra y guano, irá avivando entre ellos la memoria del último y más ruidoso suceso. Ellos se acordarían entonces de viejos libros manejados en la niñez: un Horacio, lleno de abreviadas indicaciones escolares, una colección deshojada de Selectas latinas, las oraciones de Marco Tulio, quizá alguna comedia de Plauto y, desde luego, las imprescindibles Fábulas de Fedro. También pensarían en libros más asequibles y más íntimamente amados. No les impondrían tanto estos libros; pero se oirían más profundamente, se sentirían más en el corazón: las odas triunfales de Herrera, los versos maliciosos de Alcázar, los romances de Góngora, alguna comedia de Lope. Con los recuerdos nacería el afán versista: fue Silvestre de Balboa el de más aliento: pero todos podían haber hecho aquella crónica en verso, todos podian haber rivalizado con él en los recursos mitológicos. Balboa y sus apologistas se confunden en un mismo estéril ejercicio de versificación?.

La tradición se ampliaba así a través de Chacón y Calvo a un espacio de tertulia o academia literaria, repleto de clasicidad y de formación a pesar de sus pobres resultados poéticos. Chacón y Calvo intentaba reflejar en la Cuba de comienzos del XVII, asediada por la piratería y con escasos desarrollos urbanos, una posibilidad cultural que también funcionara como eslabón hacia el presente.

Las lecturas se sucedieron. Las más rigurosas de Pichardo Moya y de Cintio Vitier enarbolan, sobre todo este último, un estado de la cuestión ordenado y valioso.

Desde la creación literaria es sobresaliente la lectura que Alejo Carpentier hace en Concierto Barroco que es otro momento más de la integración nacional y latinoamericana del poema. Cuando Amo-Montezuma, el protagonista de la novela, inicia su viaje hacia Europa, tras salir del puerto de Veracruz y llegar a La Habana, una epidemia hace que se refugie para reparar su maltratada nave en la Villa de Regla. La muerte del criado Francisquillo hace que se fije, él como señor que tiene que llevar criado a España, en un negro libre, Filomeno, del que se entera de que es biznieto de un negro Salvador que fue, un siglo atrás, protagonista de una tan sonada hazaña que un poeta del país llamado Silvestre de Balboa la cantó en una larga y bien rimada oda, titulada Espejo de paciencia...

La integración de la historia de Balboa en la obra se produce a través del relato fluido del negro Filomeno quien da cuenta de la fiesta que se produce tras la liberación del obispo Altamirano, hablando de los sátiros, faunos, silvanos, semicapros, centauros, náyades y hasta hamadriadas "en naguas», relato que maravilla a Amo-Montezuma por el lenguaje del negro que pronunciaba «tantos nombres venidos de paganismos remotos». Pero más sorpresa le crea la narración de la orquesta cuyo bullicio intenta rememorar Filomeno. $\mathrm{La}$ fusión de los instrumentos europeos y cubanos, de músicos que tocan zampoñas y rabeles junto a otros que tocan tipinaguas y marugas y tambores, provoca la reflexión de AmoMontezuma:

¡Imposible armonía! ¡Nunca se hubiera visto semejante disparate, pues mal pueden amaridarse las viejas y nobles melodías del romance, las sútiles romanzas y diferencias de los buenos maestros, con la bárbara algarabía que arman los negros, cuando se hacen de sonajas, marugas y tambores!...i. Infernal cencerrada resultaría aquélla y gran embustero me parece que sería el tal Balboa! ${ }^{10}$

La reflexión de Carpentier se enlaza más que con la historia de su Concierto Barroco con todo un debate sobre la música en Cuba 
que el propio Carpentier secundó ampliamente en su obra teórica. No puedo insistir aquí más en que Carpentier sigue las teorías de fusión musical y no privilegia la tradición europea hasta límites anulatorios de la otra. De hecho aquí no se está expresando por Amo-Montezuma. Aunque haya elegido reflejarse en el espejo de paciencia. Como imagen inversa.

También en el espejo se han reflejado algunas imágenes académicas contemporáneas. Ivan Shulman dedicó en 1989 un interesante trabajo basado en la idea de reflejo que el título representa, para considerar globalmente ideas que significan códigos en los que aparece «un espejo que refleja una sociedad inestable en proceso de formación». El reflejo social del poema es amplio para Shulmann hasta el límite de afirmarlo como un ejemplo de desplazamiento del poder cultural de la metrópoli a la colonia, protagonizado por un poeta de origen canario que afirma su insularidad en Cuba. El criollismo y el mundonovismo del poema parecen reflejos evidentes. Y el del ilustre profesor Shulmann ampliando la carga social del poema en una lectura basada en su recorrida sociología y política del texto.

El estudio de Juana Goergen es una afirmación del carácter fundacional americano a través de las fusiones de lo cubano (historia, léxico) con la tradición europea (épica, mitología). Pero la insistencia en el espacio fundacional se construye desde una lectura diferencial en la que, por ejemplo, al situar su Arcadia en Bayamo, consciente del topos tradicional de la misma, Balboa asumiría la inversión de los elementos tradicionales del topos arcádico utilizando una Arcadia urbana, la ciudad de Bayamo, como escenario. Esta perspectiva diferencial es una inversión que autonomiza el texto de Balboa de modelos europeos. La ejemplificación se abre por ejemplo a un verso como

\section{Y están Favonio y Flora en su teatro,}

como fijación y reflexión de inicio del topos Teatrum mundi que sería el que aquí iniciaría una artificiosa apariencia, en la que van a presentarse ninfas y capros como cortejo inmediato del obispo, pero lo que quiere resaltar esta estudiosa es que la palabra teatro y las escenas subsiguientes remiten a una conciencia paródica que va a ser uno de los elementos diferenciales del poema de Balboa, y, por supuesto, uno de los elementos que le dan carácter diferencial y fundacional. Dejémoslo por el momento en que la difusión del teatro de mundo es tanta que no parece que debamos conferir ninguna presencia paródica a la palabra sobre todo si está presente porque rima con cuatro:

Y están Favonio y Flora en su teatro,

Año de mil y un seis con cero y cuatro.

Y dejemos entonces toda la teoría de lo paródico para que quien se refleje en el espejo sea la autora de este trabajo y no nos aparezca una imagen encorsetada por ejemplo de Bajtin. Juana Goergen, en su libro, por otra parte interesante, ha llevado hasta el extremo las propuestas fundacionales. Oigámosla en su conclusión:

El Espejo de paciencia se nos presentará como espejo del tiempo en que se vive y de la disyuntiva que forma parte del ser americano. El sujeto colonial, representado en el poema en todo su abigarramiento cultural, se ve paralizado en las dos encrucijadas a las que lo condujo un tradicionalismo dogmático y a menudo también intolerante: aspiró a la independencia en su modo de ser histórico, pero no pudo divorciarse de los modelos y las fórmulas impuestas por la tradición europea y terminó imitándolos; quiso renovarse, estableciendo una marca diferenciadora, pero no le estuvo permitido abrazar la diferencia misma ${ }^{11}$.

Pues bien, como hemos visto, críticos e historiadores de la literatura fueron reflejándose desde finales del siglo XIX en el espejo de Silvestre de Balboa para redescubrir una línea de tradición. Las lecturas sucesivas abrieron múltiples reflejos. En cualquier caso, fundadores de una tradición cubana, detractores de la misma, llenan con sus lecturas un ámbito de nuevo fundacional, pero un ámbito que me parace valioso en el sentido de la frase de José Lezama Lima que recordé al principio. Ahora quisiera reconstruirla entera porque con Lezama a lo mejor podemos ir más allá. Recojo un texto del que hasta aquí sólo he dado fragmentos. Dice así:

La imago ha participado en nosotros a través del título de un libro de contenido escaso y pobrísimo y en la lejanía, la sentencia y la muerte de José Martí. Al comenzar nuestra literatura un libro se brinda con
11

Op. cit., pág. 118.
Siglo XVII: ecos de la épica y la arcadia italiana en Cuba: Espejo de paciencia de Silvestre de Balboa JOSÉ CARLOS ROVIRA 


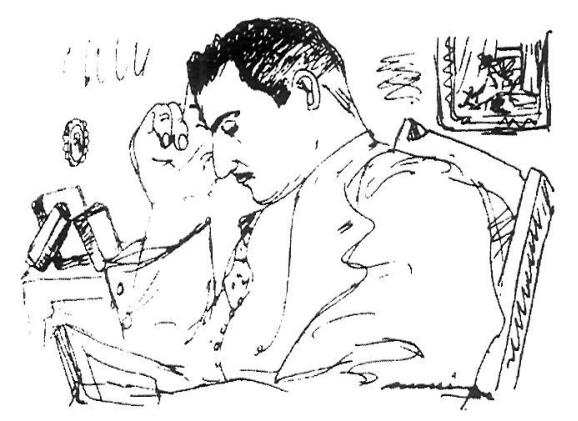

José Lezama Lima, por Mariano. un título de una fascinación mágica y severa [...] Comenzar una literatura con un título de tan milenario refinamiento como Espejo de paciencia, título que menos que un esqueleto regala una nadería, nos sobresalta y acampa, nos maravilla y aguarda. Pero supongamos que la obra alcanzase una calidad tan refinada y misteriosa, $\tan$ secular y tan contemporánea como la que su enigmático título nos sugiere. Hubiéramos comenzado con un Enchiridión, custodiado por José Martí, como el Uno-Monarca participación, con una secular paciencia de escritura, con un hieratismo en el lento tejido de las danaidas devuelto por el espejo. Está dispuesto José Martí, y es ésa su imago más fascinante junto con su muerte, a llenar el contenido vacío de ese espejo de paciencia. Su sentencia está recorrida por una paciencia que se sobresalta, cabrillea o se tiende en las coordenadas extensionables del eros sumergido en la poesía. Poco antes de su retiramiento había soñado con la escritura de un libro, que para nosotros cobra su existencia por la testarudez aragonesa de su inexistencia, que se le escapa como una frase dicha ante el lanzazo final: Sentido de la vida. Pero si aquel Espejo de paciencia lograse articular de nuevo el prodigioso avance de su título con la extraordinaria imago desplazada por la sentencia y las ejecuciones de José Martí, tendríamos entonces nuestro Enchiridión, el libro talismán, custodiado por aquellos que lograron con sus transfiguraciones, con sus transformaciones, con sus trasustanciaciones, participar como metáfora del Uno, como el uno procesional penetrando en la suprema esencia.

El texto de Lezama no indicaba una lectura independentista del espejo de Balboa por José Martí. De hecho, José Martí, aunque algunos entendieron lo contrario a través de Le- zama, no escribió nunca sobre Espejo de paciencia. Lo que nos está planteando Lezama es la imagen vacía que se hubiera llenado si Martí hubiera escrito su Sentido de la vida. Y lo que nos está planteando es la construcción imaginaria de una posible escritura que él mismo iba a intentar a llenar. La metáfora de Lezama se resuelve así en la posibilidad imaginaria de que Arriano hubiese llenado de contenido otra vez las páginas no escritas de Epitecto, la sabiduría del maestro recordado tras la muerte. El espejo de Lezama es pues más intenso. Martí-Arriano y Balboa-Epitecto hubieran tenido su Enquiridión. Y Cuba hubiera tenido así su libro-talismán, su compendio de sabiduría inicial e iniciática.

Pero la idea es en cualquier caso básica para el imaginario nacional cubano. Y es básica en cuanto se empieza a conformar a fines de siglo XIX mediante el reflejo en el espejo de Balboa de la erudición antigua y aburrida de Menéndez Pelayo o de José María Chacón y Calvo, de la erudición menos antigua pero a veces tambien aburrida de José Pichardo Moya o de Cintio Vitier, o más recientemente de las imágenes profesorales de Shulmann, González Echevarría y Juana Goergen. También la genialidad, confusa o clara, gongorina o vanguardista, verdadera o falsa (o no) de José Lezama Lima. Lo sorprendente es que, desde finales del siglo XIX, un canario-cubano de tres siglos antes pudiera crear una imagen tan erudita, tan épica, tan tópica, tan recurrente y de una poética tan torpe con la que todavía podemos hoy acercarnos, seguramente por la extrañeza lezamiana de su título, a una era imaginaria de la formación de la nacionalidad cubana. 

tituto de Literatura y Lingüística de La Habana «Juan Antonio Portuondo Valdor». Ha realizado numerosos estudios sobre las literaturas española y cubana de los siglos XIX y XX, con especial atención a la obra de Benito Pérez Galdós y la de Fernando Ortiz. Actualmente estudia el período es-

\section{DE CÓMO FERNANDO ORTIZ SUPO \\ HALLAR UNA MOZA ESQUIVA PARA CIERTO CABALLERO ENCANTADO ${ }^{1}$} pañol en la obra de Ortiz. Es miembro de la Unión de Escritores y Artistas de Cuba (UNEAC).

\author{
RICARDO VIÑALET
}

En 1909 el escritor español Benito Pérez Galdós (1843-1920) publicó una extraña novela titulada El caballero encantado, cuento real... inverosimil (Pérez Galdós, 1909), que es hoy una de sus menos frecuentadas realizaciones, a pesar de haber gozado de receptividad por la crítica especializada, y por lectores de estratos representativos de cierto nivel cultural. Las valoraciones respecto a ella se han movido dentro de un espectro amplio, de modo que ha resultado controvertida.

Un interesante ejemplo a la altura de 1979, septuagésimo aniversario de su aparición (por cierto, no agota el interés de los estudiosos, pertinaces en volver constantemente su mirada a la obra hasta nuestros días), es un artículo del profesor Peter A. Bly (Bly, 1979: 20-29). luego de señalar que no es de las más conocidas novelas de Pérez Galdós, se refiere a la diversidad de ópticas asumidas para interpretarla y evaluarla, casi desde su aparición. Menciona a más de una decena de autores e incluye diversas citas, incorporándolas a su propio discurso con el objetivo de fundamentar la tesis que sustenta.

Bly alude a la evidencia de nexos entre el pensamiento de Joaquín Costa - y, por ello, al espíritu de la llamada Generación del 98con Pérez Galdós, incluso en momentos en que cierto pesimismo abatía al destacado reformador. (Una copia dedicada fue recibida por Costa, gesto que agradeció en misiva al autor).

Entre las opiniones coetáneas de la novela introduce una de José María Tenreiro, quien destaca su patriotismo, la apertura de una esperanza para creer en la resurrección de España y la calidad del libro. Transcribe asimismo el encomiástico criterio de Eduardo Gómez de Baquero (Andrenio), escrito unos años más tarde.

De Joaquín Casalduero incluye un juicio que enfatiza el lado social y nacional de la obra. También aparece citado José Schraibman, cuya lectura de El caballero... le conduce a confiar en el papel de la educación como vehículo dinámico regenerador de España. Al acotar a Gustavo Correa vuelve sobre el tema de la cercanía entre Galdós, la Generación del 98 y sus ideales programáticos de una nueva y distinta vida nacional.

Más extensamente recoge Bly conceptos de Julio Rodríguez Puértolas en torno a las convulsas circunstancias hispanas en la fecha de publicación de la novela, y a la inexcusable necesidad de hallar una salida. Con tal prisma la interpreta el aludido investigador, quien insiste en la presencia de Costa dentro de la creación galdosiana, dados el carácter educativo, la denuncia social y la crítica política en ella presentes, subrayándole así implicaciones noventayochistas.

Contrasta, sin embargo, el enfoque del aparato referencial empleado por Bly con la significación que terminará por proponer. Según él, esta novela se resiente de su alcance social debido a que los caracteres - sobre todo protagónicos- pecan de un marcado acento individualista, de sentimientos exagerados acerca de su propia personalidad, de tener una
1

Una versión abreviada, con el título "El caballero encantado en la óptica cubana de Fernando Ortiz: un enfoque sociopolítico regeneracionista e intertextual en 1910», fue presentado por el autor como ponencia en el $6^{\circ}$ Congreso Internacional Galdosiano: Galdós y el 98, celebrado en Las Palmas de Gran Canaría, España, del 16 al 20 de junio de 1997.

De cómo Fernando Ortiz supo hallar una moza esquiva para cierto caballero encantado RICARDO VIÑALET 
«Mi interpretación acerca del examen que Galdós realiza, a propósito de estos problemas sociales, pudiera ser criticada por su falla en considerar el marco fantástico en que dicho examen se sostiene» [Trad. R.V.].

3

«El caballero encantado puede ser obra de un cansado novelista profesional de sesenta y seis años de edad, pero su tema permanece eternamente relevante para juveniles e idealistas reformadores sociales. Su sutileza de composición es digna de un escritor más joven» [Trad. R.V.].

4

El biógrafo de Galdós y crítico literario Emilio Gutiérrez Gamero - citado por Federico Carlos Sainz de Robles sin precisar la fuente-, al sintetizar el argumento, afirma que "se trata de un curioso capricho [...], en el que tras mostrarnos la vida hueca, falsa, egoísta, inútil y cruel de los que sólo piensan en satisfacer sus pasiones, sus vicios o su bellaquería a costa del trabajo agotador de los humildes (que, a más, es improductivo para éstos), hace que, por arte mágica, esos mismos que malbaratan vida y hacienda absurdamente se vean cara a cara con la realidad $y$, metamorfoseados en pobres gañanes o en vulgares peones de otros trabajos igualmente rudos, aprendan en la práctica lo inicuo de su proceder cuando fueron ri$\cos$ y poderosos, empleándose en labores que exigen esfuerzo y constancia, viendo las miserias y los padecimientos de quienes carecen de todo porque hasta ellos no ha llegado ni el bien de la instrucción, a que todos tienen derecho, ni el cuidado más elemental por mejorar las condiciones de vida, ni la protección que les es debida, contra los abusos de todo género que con ellos cometen los eternos mangoneadores pueblerinos, que los tratan más como a rebaño que como a seres humanos» (Sainz de Robles, 1951: 221).

De cómo Fernando Ortiz supo hallar una moza esquiva para cierto caballero encantado

RICARDO VIÑALET vida en lo esencial guiada por las apetencias sexuales, y de atender más a los aspectos materiales de la existencia que a los espirituales. Según Bly, se produce así un debilitamiento en la intención social regeneradora. Los elementos apuntados le conducen a valorar más la obra como de propuestas morales y no sociales.

Cierto es que en El caballero... se percibe una novela de planteamientos éticos, aunque el criterio de Bly deviene algo redundante, si se tiene en cuenta que la ética es hecho y disciplina sociales, colectivos, a pesar de que se asuma individualmente. La moral se establece desde parámetros socialmente condicionados, por ende una obra de reflexión ética lo es también -y por ellode reflexión social.

El profesor Bly llega, quizás, a tal interpretación porque ha partido de otra previa, equivocada a mi modo de ver: asume $E l$ caballero... con un enfoque demasiado literal, como si se tratase de analizar una más de las creaciones galdosianas donde el autor es convencionalmente realista. Por consiguiente, le es imposible acceder a otras lecturas más en correspondencia con la tónica fantástica y la naturaleza simbólica que ella tiene. Lamenta, incluso, que la ficción resulte increíble. No logra situarse desde el prisma de la fantasía, hecho explícito además por Galdós en el subtítulo. La dimensión social de $E l$ caballero... es muy evidente si el lector se ubica en la inverosimilitud aparencial. El profesor parece alcanzar conciencia de la fragilidad de su análisis cuando afirma: «My interpretation of Galdós examination of these social problems could be criticized for its failure to take into account the fantastic frame in which the examination is held $»^{2}$ (Bly, 1979: 24).

El catedrático de Queen's University, habiéndose colocado en una inquietante literalidad, sostiene que la novela resulta superficial e insuficiente en sus propuestas. El único sostén ajeno citado en su argumentación es el siguiente de Hans Hinterhaüser: «Desde el punto de vista artístico, habría que hacer muchas objeciones a esta novela; una gran cantidad de motivos secundarios ahogan el tema principal, de modo que surge algo así como un confuso resumen de las experiencias propias de la vejez de Galdós» (Bly, 1979: 28).
Tal vez comprendiendo al final que ha ido demasiado lejos, intenta ser conciliador en la conclusión de su ensayo, y dice: «El caballero encantado may be the work of a tired sixty six-year-old professional novelist, but its theme remains eternally relevant to youth's idealistic social reformers. Its subtlety of composition is worthy as a younger writer» ${ }^{3}(\mathrm{Bly}$, 1979: 28).

En definitiva, está reconociendo tanto la significación social de El caballero... como la astucia de creación, la validez artística de la obra y hasta el vigor juvenil que de ella emana.

Valga la muestra presentada para ilustrar cómo a pesar de la diferencia de matices con que El caballero... haya podido ser recibida por la crítica, existe consenso en cuanto a las intenciones que animaron a Galdós por plantear una meditación en torno a España, su historia, su presente y perspectivas.

La obra re-edita, no sin ironía, el aire de los viejos relatos caballerescos, donde encantamientos y otras circunstancias de esta suerte devienen lugar común. Hay también espacio para diversas modalidades narrativas de los siglos XV y XVI, tales como la novela pastoril, sentimental y picaresca. Dadas esta capacidad aleatoria y la índole de la fábula, de inmediato se percibe el aura quijotesca, en la cual - tras una aparente inocencia de las peripecias hilvanadas - se agazapa el objetivo de más trascendentes pensamientos. Así Pérez Galdós inscribe su creación desde claves simbólicas y desarrolla un discurso literario parabólico en torno a las particularidades de su tiempo y al estado de España. No obstante, en El caballero... se advierte la ausencia de la socarronería cervantina, su humorismo, capacidad para la burla sutil y la parodia. Esta es más iracunda, severa y explícita. Desde la concepción de los personajes hasta el subtítulo transparentan las intenciones galdosianas ${ }^{4}$.

Por otra parte, la formulación real... inverosimil es útil para insistir (incluso hoy) en que no puede circunscribirse el realismo a determinado método de creación, aspecto muy importante para mostrar la inconveniencia no sólo de entender el realismo casi unidimensionalmente, sino de encasillar a Galdós en procedimientos literarios muy específicos del siglo XIX. En El caballero... 
hay un momento en que el protagonista abandona «el concepto de lo real para volverse al de lo maravilloso» (Pérez Galdós, 1909: 240). Poco después, desde lo maravilloso comprenderá que se encuentra en otra zona de lo real, muy próxima a la nombrada, cuarenta años más tarde, «lo real maravilloso» por Alejo Carpentier, desde luego con perspectiva diferente. Quizás en esta novela de Galdós pudiera hablarse de lo maravilloso real.

De hecho, el español tampoco descubrió el asunto, pues El caballero... se factura con antecedentes aportados ya en El Quijote, homenaje presumiblemente consciente a quien de modo igual maravilloso y real fue capaz de proponer un hondo análisis de su tiempo y lugar.

El tema, obsesivo en la literatura del último cuarto del siglo XIX, se hizo agónico alrededor de 1898 y en los años inmediatamente posteriores.

Ante la difícil situación en todas las esferas de la vida nacional, la creciente conciencia de que el país se rezagaba con respecto del resto de Europa; que el poderoso imperio colonial era ya simple memoria, empezó a delinearse una actitud entre la intelectualidad que llevaba como divisas el pesimismo, la insatisfacción y el espíritu crítico. En el terreno de las ideas ocuparían espacios importantes Hegel y, sobre todo, el positivismo. Se conformaba el juicio colectivo de que, ante el descalabro nacional y la decadencia correspondiente, era preciso encontrar un remedio que revirtiera el proceso.

El krausismo constituyó un esencial movimiento ideológico abanderado de la renovación española. Como se conoce, tomó su nombre del filósofo alemán Christian Friedrich Krause y le dio inicio Julián Sanz del Río. Seguidores suyos le imprimirían notable impulso. No obstante, el peso no recayó en el terreno estrictamente filosófico, sino en el educacional, que se consideró la vía inmanente para la transformación. Devino plataforma expresiva del rechazo a las circunstancias en que se vivía. Continuadores de Sanz del Río, entre los que descuellan Francisco Giner de los Ríos y Joaquín Costa, fueron autores de textos impregnados del ansia modificadora y estuvieron imbuidos de hondo espíritu crítico.
Han sido justamente llamados los krausistas educadores de la España contemporánea, ya que junto al valor que en sí mismos tienen; al de constituir otra vuelta de tuerca para el movimiento reformista del siglo XVIII y, a la

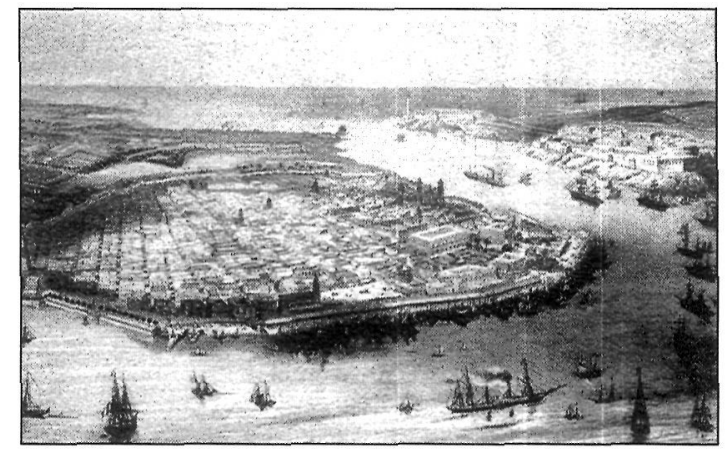

Bahía de La Habana. Litografía de Assilineau, siglo XIX. vez marcar el preámbulo de la llamada Generación del 98, asimismo son fundacionales para otros alientos que se vinculan a las ideas y a la creación literaria más adentrado el siglo XX. El krausismo tiene mucho que ver con el afán de mejoramiento axiológico para varias promociones de españoles. En consecuencia, llega a ser un enlace de angustias, aspiraciones y juicios críticos de hombres anteriores al siglo XIX con los del siglo XX. En rigor, el complejo de decadencia puede rastrearse en la literatura española, al menos, desde el siglo XVII con Cervantes y Quevedo. En el XVIII es perceptible en figuras como Gaspar Melchor de Jovellanos y José Cadalso, entre otras.

Coincidentemente con el krausismo sobreviene, como es sabido también, el período literario realista-naturalista, etapa en la que comienza Pérez Galdós su carrera de escritor. Atípico resulta su caso, pues si cronológicamente habría que situarlo en la promoción inicial, su obra la rebasa por estar más cercano en los temas y en el espíritu a la segunda, aunque su trayectoria, técnicas artísticas y concepciones lo llevan a ser hombre y autor contemporáneo.

Verdaderamente es en el año 1898 cuando sobreviene el clímax. La pérdida de $\mathrm{Cu}-$ ba, Puerto Rico y Filipinas, más el ya apuntado proceso de deterioro económico y sociopolítico, harían que ese instante histórico fuese denominado el desastre. Constituyó una crisis de las conciencias. En muchos españoles quedó un amargo sabor, incluso en algunos que no se caracterizaron por el conservadurismo. No hay que inferir en todos los lamentos por la derrota una actitud imperial o imperialista, sino que -en medio de serias contradicciones de múltiple signo- vieron en la pérdida de las colonias 
la manifestación suprema del descalabro total de su patria.

La denominada usualmente Generación del 98 emerge, pues, como una suerte de movimiento que, a partir de cuestionarse la situación nacional en todos los órdenes, cobra un sesgo marcadamente intelectual y posee manifestaciones de gran importancia en el terreno literario, ámbito en el cual desarrollaron gran parte de su pensamiento crítico y afán renovador. Por ende, la temática más abordada tuvo que ver con el estado de insatisfacción, con la crisis global española, con la corrupción, la intolerancia religiosa, la rigidez escolástica en las formas de vida, el conformismo, la mediocridad: reaccionaron contra todo ello adoloridos por su país. Al propio tiempo desearon abrirse a las más novedosas corrientes del pensamiento europeo, esto es, se trazan como objetivo la europeización de España: europeizadores con pasión española, ya que volvieron los ojos de igual manera a su historia, intentando comprender los orígenes de los males. Su mirada se detuvo, atenta, en los campos, aldeas y pueblos, en los paisajes, en el folklore, en lo tradicional, en su identidad.

Desde un punto de vista estrictamente literario, se planteó una voluntad de estilo dentro de la diversidad de sus integrantes, que se vinculaba al interés de dignificar el espíritu hispano, al afán regenerador, a una nueva españolidad.

Contexto ineludible de la Generación del 98, pero no sólo de ella, es el llamado regeneracionismo. Con frecuencia éste queda circunscrito a movimiento ideológico desarrollado en España a consecuencia del desastre de $1898 \mathrm{y}$, en tal sentido, su alcance se limita a tentativas de modificar la vida política del país.

Por todas las consideraciones que se han venido exponiendo, puede extenderse en tiempo y espacio el ámbito regeneracionista, incluso llevarlo más allá de las fronteras hispanas. Si regenerar implica el restablecimiento o la mejoría de algo que ha degenerado; si presupone en seres humanos y en colectividades el abandonar hábitos o conductas reprobables, puede coincidirse en que la crítica a la sociedad española se vislumbraba con determinada sistematicidad desde, casi, los inicios del último cuarto del siglo XIX, y aun antes con menor coherencia.
El movimiento regeneracionista apunta a las ideas y clama por la reconsideración de la vida política; no obstante, su esencia va más lejos y se expande totalizadoramente desde una asunción ética, de apego a los genuinos valores de la espiritualidad hispana, de su cultura, con marcado interés por la modernización de las estructuras en el país y en las mentes. Su presencia es impactante en el pensamiento, pero también en la literatura. Ver$\mathrm{dad}$ es que el regeneracionismo se delinea con precisión alrededor de 1898, aunque su aliento llega desde otros tiempos, por lo cual es factible asumir el concepto con sentido amplio y perspectiva dialéctica (Viñalet, 1996: 27-29).

Benito Pérez Galdós, creador que no forma parte del grupo conocido como Generación del 98, a pesar de ciertas coincidencias, es un magnífico exponente de escritor regeneracionista, no sólo en la obra producida durante los años que vivió del siglo XX, sino desde su primera época. Baste recordar Doña Perfecta (1876) y La familia de León Roch (1878). Los Episodios Nacionales, que se inician en 1873, con certeza no escapan al intento de reflexionar sobre España, en este caso procurando integrar lo novelesco y una interpretación de la historia. La literatura galdosiana, desde el principio, colocó a los españoles ante el tribunal de sus propias conciencias (Viñalet, 1984: 100-129).

El conservadurismo, el catolicismo intolerante y, en general, las fuerzas retrógradas sintieron - con razón - en Galdós a un enemigo. Fue éste hombre y escritor de preocupaciones constantes por los problemas nacionales, tanto aquellos de índole política como los de naturaleza ético-sociales, dentro de los que se destaca el interés por la historia del país, en especial la del siglo XIX.

Su obra, que alcanza el carácter de monumentalidad por la amplitud, variedad y profundidad, sobresale por el mensaje de que es portadora: el rechazo de lo injusto, lo abusivo y lo arbitrario. La irracionalidad de los tiempos por él vividos llegó a ser tan grotesca como algunas piezas de Goya, y Galdós llevaba a un pintor dentro de sí.

Sus personajes, capaces de alcanzar la representación de vicios o de virtudes, son dados por el autor desde lo hondo de sus sentimientos de amor, caridad y verdad. No
De cómo Fernando Ortiz supo caballero encantado RICARDO VIÑALET 
devienen meras alegorías porque se hallan en relación dinámica con el medio. De ahí que haya creado un genuino universo de caracteres. Fue Pérez Galdós baluarte, tenaz defensor del pueblo, de lo verdaderamente popular, que se convierte en esencia de su creación artística.

La óptica realista, progresiva que guió su vida y su producción literaria, estuvo matizada con ciertos idealismos utópicos en las aspiraciones reivindicativas con que soñó. Es necesario buscar la esencia de los anhelos galdosianos en las ideas de la tolerancia, del amor y la comprensión; en esa tríada - pensaba- se encontraría la senda para la conciliación de las pugnas nacionales. Deseó una armonía sociopolítica e individual entre cada hombre, apoyada en la justicia, en modos de distribución menos desiguales para la riqueza; ansiaba que cada ser humano pudiera ser expresión libre y sana de sí mismo, sin perjuicio de otros. Bellos sueños, estrellándose contra una realidad que no admitía conciliaciones. Escapaba a Galdós cómo las contradicciones, si son antagónicas, no cejarán hasta el estallido, muy especialmente en las condiciones españolas del siglo XIX, y aun del XX como se ha encargado de probarlo la historia en que el escritor tanto hurgó.

El caballero encantado, novela no de vejez intelectual, sino de concretas y reales meditaciones angustiadas en hombre de espíritu sensible, es consecuente con la trayectoria vital de su creador. Por ello, Sainz de Robles, delicado, respetuoso y fascinado, considera: «Es una narración deliciosa. [...] El simbolismo es siempre el mismo: la historia, España [...] Siempre fue Galdós un apasionado español. No poco si afirmo que el más español de todos los grandes escritores del siglo XIX. Español con orgullo inmenso de serlo y con optimismo jamás entibiado en futuros destinos españoles. Con los años, el patriotismo incondicional de Galdós se fue exaltando hasta límites que causan una emoción vivísima. $\mathrm{Y}$ es en la última serie de los Episodios Nacionales y en El caballero encantado [...] donde con más ahínco hace su inmensa profesión de fe. Ciego, torpe, un poco desengañado de todo, se refugia en su todo: España. $Y$ la ve mejor que nunca. Y mejor que nunca la penetra y la entiende» (Sainz de Robles, 1951: 221-222).
Si deliciosa es una palabra que emplea Sainz de Robles para calificar la novela, varias décadas antes el cubano Fernando Ortiz la llamaría divina e, inspirado por ella, en 1910 publica una versión libre y americana que titula El caballero encantado y la moza esquiva (García-Carranza, 1970: 36 y 71).

La simpatía sentida por Ortiz hacia El caballero... obedece tanto a razones literarias como extraliterarias.

En el primer caso, existe amplia referencia de cuánto admiraba a

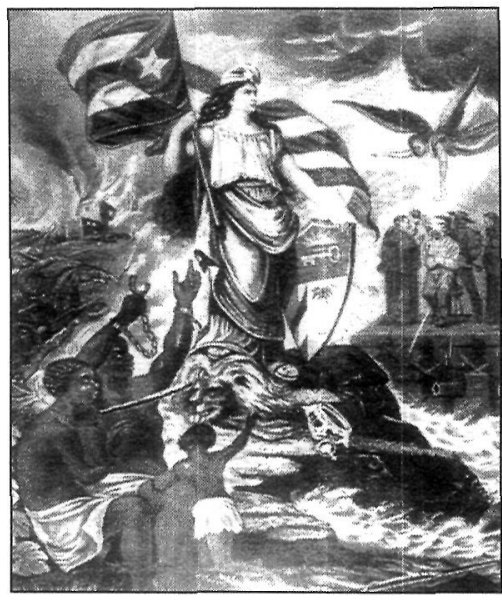

Alegoría a la República cubana. Pérez Galdós (Ortiz, ¿1911?). Reconoce la maestría del escritor canario para crear en esta oportunidad una novela fantástica, sobrenatural, especie de jornada onírica donde el tiempo marcha caprichosamente y despla$\mathrm{za}$ a los personajes por diversos planos, no sólo temporales, sino espaciales, envueltos en magia y misterios. Ha gustado de la propuesta simbólica -esencial en el relato-, pues le incita a la diversidad de lecturas y él asume una interpretación. Desde ella elabora suversión libre y dará un consejo al lector, según Ortiz válido para el acceso al original $y$, por ende, a la traducción que él emprende: «Avive el entendimiento el que quiera seguir leyendo si no es ducho en simbolismos, que el maestro Pérez Galdós nos exige a todos en este caso imaginación cautelosa al par que avispada para darnos justa razón de lo que se descubre en los repliegues de su lenguaje y se transparenta tras el velo de las personificaciones y sucesos, a veces borrosos, por el misterio que - para mayor atracción- los rodea como neblina. El caballero encantado debe leerse dos veces, una al correr de la vista sobre las páginas, otra más pausada y entre líneas toda ellas» (Ortiz, ¿1911?: 256).

Las consideraciones extraliterarias radican en la temática y en su significación, dadas las específicas circunstancias en que fue escrita, y en las que se produce la recepción de don Fernando. Como El caballero encantado plantea el asunto de la regeneración de España desde el prisma sociohistórico y ético, toca de lleno en preocupaciones suyas en esos años primeros del siglo, por su incidencia en la vida cubana. De ese mismo carácter es su interpreta-
De cómo Fernando Ortiz supo hallar una moza esquiva para cierto caballero encantado

RICARDO VIÑALET 
ción e, inevitablemente, con tal sentido - desde la otra orilla del Atlántico y enfoque americano- escribiría El caballero encantado y la moza esquiva.

El descalabro español y nuestra gesta independentista se hallan en el centro del problema. En Cuba, el 98 hubo de tener una violenta repercusión. Baste apuntar que la noción del desastre fue también para nosotros una dolorosa realidad. Los ideales y luchas liberadoras desembocaron en frustraciones gigantescas. El final del dominio español coincidió con la intervención norteamericana y sólo en 1902 nació la república, como se sabe distante de los sueños y mutilada por la Enmienda Platt, que nos condicionaba a los intereses y apetencias del vecino poderoso. Tal fue el signo de aquellos primeros años. La historia es prolija en recoger las disputas civiles, revueltas militares, la segunda intervención armada estadounidense, la corrupción social, administrativa y política. Duros tiempos en que ganaron terreno el escepticismo y el desengaño.

Núcleo de las preocupaciones y acción de cubanos ilustres fueron el mantenimiento de la identidad nacional, de la nación misma; la conciencia de que era necesario remediar la crítica situación; la comprensión de lo impostergable de indagar acerca de la identidad cultural, esto es, quiénes, qué y cómo somos. Era un modo de encarar el reto.

Dentro de los primeros esfuerzos de Fernando Ortiz, no pocos se dirigieron al autoexamen, al autoconocimiento del cubano (Serrano, 1987). Asimismo emprendió una cruzada en pro de la dignificación ciudadana en aquella república artificial y exhausta desde el mismo 20 de mayo de 1902, cercenada en la soberanía, urgida de emprender un camino largo y arduo de ascensión ética, social y política. Ortiz recogió el guante; percibió que por ahí se marcaba un rumbo para alcanzar los objetivos: regeneracionismo desde la derrota, la pobreza y la identidad, tan afines evaluó las circunstancias cubanas y españolas. Un regeneracionismo desde la otra linde, transculturado.

La inquietud renovadora, asimilada creativamente en sus estancias españolas, devino génesis del quehacer sobre Cuba, sus problemas y su cultura. Las confluencias que en su obra, de principio a fin, se observan entre re- generacionismo, identidad nacional y cultura son la espina dorsal de todo Fernando Ortiz.

Pero entre ciertos regeneracionistas hispanos, había algunas zonas oscuras y sobre ellas don Fernando se manifestó muy crítico. Una fue el panbispanismo, verdadero intento neocolonialista por someter a Hispanoamérica a la tutela de la ex-metrópoli. Derrotada completamente en el terreno militar, cruzó por la mente de algunos la idea de que España volviera a imperar en las antiguas posesiones mediante el ejercicio de influencias y de privilegios económicos. Maltrecha y rezagada, ansiando europeizarse para hallar una senda emergente de salida a sus males, con elevados índices de analfabetismo e incultura, así como con agudos conflictos sociopolíticos, pobre modelo habría de ser para las repúblicas hispanoamericanas. Desde tales presupuestos rechazaba Ortiz el frenesí panhispanista.

No pocos voceros de esa tendencia elaboraron un discurso oportunista. Llegaban a argumentar que, o España ejercía su misión tutelar sobre Hispanoamérica, o ésta caería bajo el hegemonismo norteamericano. Así el viejo imperio estaría llamado a rescatar a sus hijas de las fauces del imperialismo yanqui, joven y pujante. Claro que nada iba a impedir que Estados Unidos se lanzara a convertir a Nuestra América en su traspatio. Las intenciones y hechos están a la vista y en la memoria. La maniobra panhispanista sólo ofrecía optar entre dos imperialismos.

Fernando Ortiz, como otros cubanos lúcidos, comprendió de qué se trataba. $\mathrm{Al}$ respecto abunda en La reconquista de América; reflexiones sobre el panhispanismo y en Entre cubanos: psicología tropical, libros que agrupan textos diversos, en su mayoría aparecidos en publicaciones periódicas entre 1905 y 1913, muchas veces al calor de polémicas.

Encarando la esencia del dilema en sus formulaciones polares, insistirá en el rumbo de las soluciones: «Engendros anémicos de un imperialismo que moría, hemos seguido embrutecidos en la modorra tropical, de la que despertaremos tarde, cuando otro imperialismo que crece nos haya arrastrado en su torbellino. [... ] Sólo una civilización intensa y difundida podría salvarnos; siendo cultos, seríamos fuertes. Seámoslo» (Ortiz, 1913a: 77- 
78). La salvación desde la cultura es la propuesta, de clara ascendencia krauso-positivista, estandarte ideológico del regeneracionismo y del grupo dado en llamar Generación del 98. Sin embargo, en esta versión cubana que Ortiz plantea está clamando por la existencia de la nación, sosteniendo el escudo de la identidad nacional desde la cultural.

Don Fernando, con nítido concepto de esa, nuestra identidad, no hilvanaría ideas apendiculares de la ex-metrópoli, sino acerca de la importante tarea que a ella correspondería. Por tanto, incita: «Esto es lo que debería hacer España, traernos cultura, mucha cultura, porque cuando España impere por su cultura y por el genio científico de sus hombres nuevos, entonces, entonces sí, la América entera será verdaderamente española, hasta la que hable inglés, porque en los tiempos que corremos la civilización es la que une a los pueblos» (Ortiz, 1913a: 107).

El pensamiento estratégico de Ortiz busca la integración de las repúblicas hispanoamericanas, lejos de los intentos panhispanistas y tratando de evitar la absorción por parte de los Estados Unidos. Es bien explícito: «Si nos convencemos y conseguimos llevar a la realidad [...] la asociación para la lucha, podremos algún día presentar un bloque mental iberoamericano bien unido, resistente y bien caracterizado» (Ortiz, 1913a: 17-18).

$\mathrm{He}$ aquí, pues un conjunto de hechos que motiva el surgimiento de El caballero encantado y la moza esquiva.

El título pero, sobre todo, el subtítulo versión libre y americana, pudieran conducir inicialmente a pensar en un Fernando Ortiz narrador. Existen, de otro lado, como antecedentes un cuento escrito en su etapa de estudiante de bachillerato, publicado en $\mathrm{Me}$ norca, así como el folleto Principi i prostes (Ortiz, 1895), de artículos costumbristas, en menorquín, que por su índole incorpora elementos de la narrativa (García-Carranza, 1970: 15).

Si tal óptica fuera asumida, El caballero... y la moza... requeriría de juicios específicamente literarios y la obra —en tanto novelacarecería de valores para destacarse en el género. La esencia del fenómeno está en que Ortiz no pretendió novelar. Se trata de una interpretación, de una reconsideración, de una reescritura que persigue el objetivo de desarrollar un discurso político regeneracionista y opuesto al panhispanismo. No por otra razón forma parte de La reconquista... Ha manipulado a la literatura; juega con ella y la resultante es una suerte de sátira con ribetes paródicos, lo cual sí demuestra en don Fernando la conciencia estética (algo, por demás, muy habitual en su obra). De esto a presumir intentos de creación nove-

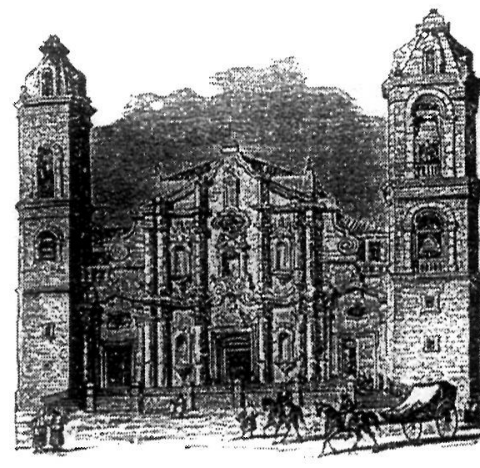

Catedral de La Habana (grabado del siglo XIX). lesca hay una distancia larga.

Aún măs, Ortiz es bien transparente al declarar sus pretensiones. En el prólogo, cuando alude a la obra de Pérez Galdós, expresa: «Buscad el libro y leed la más curiosa e instructiva historia española de estos tiempos, mas [...] hela aquí, monda y lironda, sin los afeites y colores que le diera el esclarecido ingenio de su primer narrador" (Ortiz, ¿1911?: 255-256).

Podará, nos ha dicho, ha de sintetizar y simplificar porque su obra es otra e insta al lector a procurarse la original, de manera que esté en capacidad de acceder al texto matriz, diferente del suyo, donde han de constatarse hasta alegatos complementarios o, llanamente, diferentes. Luego declara: «Aquí el propósito. $\mathrm{El}$ autor de estas líneas somete a su fantasía la magistral novela [...] y la interpreta desde puntos de vista americanos, subrayando los episodios y dichos principales que más pudieran interesar a los hijos de América» (Ortiz, ¿1911?: 256). En la más literal y sabrosa acepción del término estamos ante un texto tendencioso.

En El caballero encantado y la moza esquiva se observan tres partes: un corto prólogo con claves interpretativas; la versión propiamente dicha de la novela galdosiana, cuyos capítulos y títulos no se ajustan al primario; y un epílogo que trasciende los criterios del escritor hispano.

De la primera se ha tratado. En la segunda, la narración queda reducida en, aproximadamente, dos terceras partes y el número de capítulos desciende de veintisiete a catorce. En nota al pie de página del Capítulo I, Ortiz explica: «Ni los capítulos de esta traducción, ni sus títulos, corresponden a los respectivos del original español» (Ortiz, ¿1911 ?: 257), o sea, insiste en su libre hacer, en llevar al esqueleto
De cómo Fernando Ortiz supo hallar una moza esquiva para cierto caballero encantado

RICARDO VIÑALET 
Ortiz ubica el parlamento en el Capítulo II, mientras Galdós lo hace en el |il, muchos más extensos éstos que los de la versión. (Cotejado con Obras Completas de Benito Pérez Galdós, tomo VI, ed. cit., pág. 232. Los restantes cotejos se realizan sobre la misma fuente).

Cotejo: pág. 233 la anécdota, muchas veces glosando en pocas palabras lo que en Pérez Galdós resulta prolijo, y también volviendo a llamar la atención acerca de su papel de traductor, vale decir, de interpretador.

El tono de esta glosa llega a ser humorístico e irónico, y don Fernando revela una estupenda capacidad para caracterizar personajes y situaciones, a veces mediante el empleo de simples adjetivos: «Un amigo conservaba Tarsis decadente. Pegadizo, sablista y sabio machacón era D. José Augusto del Becerro, muy metido en legajos e infolios, apasionado por rompecabezas heráldicos, maniático por erudiciones históricas, rebuscos de archivos y bibliotecas, pápiros, pergaminos e incunables, hasta caer de bruces en la curiosa chifladura de llamar hermanas queridas a la Edad Media, a la de Piedra, a la Época Fenicia y a la Romana y a muchas otras hijas de la prolífica Historia Española» (Ortiz, ¿19 11?: 259).

El fragmento del párrafo transcrito lleva a Pérez Galdós varios capítulos de su novela, con diferente punto de vista narrativo, ya que no enjuicia las actitudes del personaje. Ortiz, de otro lado, asume una visión del Sr. Becerro que, en medio de una humorada, entrega ya hecha al lector.

Hay oportunidades en que don Fernando convierte al propio Galdós en participante de la versión, con el mismo espíritu que se aprecia en el ejemplo anterior: «En la fecha en que la narración comienza, cuando Pérez Galdós entró en tratos con Don Pueblo, digo, con Don Carlos de Tarsis, éste se sentía desesperado, tristón, pesimista...» (Ortiz, ¿1911?: 259-260).

También emplea el recurso de citar textualmente pasajes, relativamente breves, de la obra original, como apoyatura de su enfoque $y$ de los matices, un verdadero trabajo de intertextualidad. El Tarsis escéptico se lamenta: «El teatro clásico, con su Lope y su Tirso, me carga también y siempre que voy a una función de esa clase, llevo la mala idea de descabezar un sueño en mi butaca. Una obra del teatro clásico se titula como debieran titularse todas: La vida es sueño. Digo y repito con pleno convencimiento que no tenemos agricultura, como no tenemos política ni hacienda. Todo esto aquí es puramente nominal, figurado, obra de monos de imitación, o de histriones que no saben su papel. Aquí no hay nada. Cuanto veis es bisutería procedente de saldos extranjeros» ${ }^{5}$ (Ortiz, ¿1911?: 261).

En otro fragmento, de nuevo citando a Galdós, arguye el personaje: « $i$ Trabajar! ¿Para qué? Los chispazos, los resplandores de fuegos fatuos que vemos en literatura, en artes gráficas y en algún otro orden de la vida intelectual, no nos invitan a que trabajemos. Todo nos llama al descanso, a la pasividad, a dejar correr los días sin intentar cosa alguna que parezca lucha con la inercia hispánica. Si me pusieran en el dilema de trabajar o perecer, yo escogería la muerte. El español que en este final de raza posea en renta, debe sostenerla y aumentarla si puede. Vivir bien mientras la vida dure, y mientras en la lámpara del bienestar no se consuma la última gota de aceite. No trato de presentarme como superior a los demás. Soy el peor, soy el último perezoso, el último sacerdote o monaguillo de la inercia. Mi único mérito está en la brutal sinceridad de mi pesimismo» ${ }^{6}$ (Ortiz, ¿1911?: 263).

Luego que Tarsis se ha prendado de una bella sudamericana, ella lo rechaza y sobrevienen nuevas peripecias, se produce el encantamiento del protagonista. El cínico, holgazán, pesimista y ricachón se trueca - por arte de magia - en pobre mozo que ha de pasar vicisitudes innumerables y éstas le harán comprender cuán vacía y decadente, explotadora, fue su vida anterior. Esto le llevará a reevaluarla y a asumir una posición activa, regeneradora, comprometida con los humildes a quienes tanto había despreciado y sometido.

En el proceso desempeña papel fundamental un personaje llamado La Madre, maga con poderes limitados, suerte de reencarnación de la maltrecha hispanidad. En sus manos estará el hechizado hasta el completamiento de su transformación positiva.

A lo largo de un diálogo que sostiene Tarsis (devenido el pelagatos Gil) con La Madre, éste enumera un grupo de defectos que caracteriza a los españoles de la decadencia. Empero su óptica, aun consciente de los desafueros cometidos por los ricos contra los pobres, no pretende subvertir el status, sino que reclama a los poderosos que lo sigan siendo, aunque ricos buenos, para que los pobres 
lo sean menos y también buenos: dar sin quitar a nadie, así sea esa riqueza resultante de la más abusiva expoliación. Aquí Ortiz vuelve a anotar a Galdós, en punto altamente revelador de tales idealizadas concepciones: «Somos iguales, y el pobre y el rico, el plebeyo y el noble, nos hallamos en venturosa fraternidad; por ella vivimos» ${ }^{7}$ (Ortiz, ¿1911 ?: 275276). Si bien esta sublimación no forma parte de las opiniones de don Fernando, él respeta la intención sana que la provoca, no polemiza y cuando prosigue el relato, ya con sus palabras, comenta: «Donosa lección [...] que podría aprovecharnos por igual a todos, al hispano hablador para su vida nueva trabajosa y dura, y al americano parlero en su labor de esperanzas» (Ortiz, ¿1911?: 276). Va intercalándose de esta manera la proyección americana con que ha deseado elaborar su versión.

Sin embargo, en ocasiones no puede menos que disentir, sobre todo cuando de la americanidad se trata: la amada de Tarsis sufre también de un hechizo que la transforma de Cintia en Pascuala; de hermosa sudamericana capaz de rechazar a Tarsis por sus defectos, en una maestra rural de España. Ortiz lo admitiría si se tratara, simbólicamente, de mostrar cuánto han de aprender los hispanos de sus excolonizados, pero no deja pasar la oportunidad para el señalamiento irónico y humorístico: «Si de Tarsis sabemos desaciertos y majaderías que a la Madre inspiraron un encantamiento por bien, no sabemos que la ingenua Cintia tuviese mataduras [...] ni que se hubiese apartado del bien y que al bien hubiese de volverla el amor a la Madre común. [...] Por lo que quizás este largo capítulo estaría mejor titulado así: Donde aparece una Pascuala y donde el encantamiento o no es o es injusto o es sólo del caballero» (Ortiz, ¿1911 ?: 287). Un fustazo, pues, a cualquier atisbo panhispanista.

El cese del hechizo sólo se producirá cuando La Madre considere cumplida su misión regeneradora; en el espíritu galdosiano ello tendrá lugar dentro de un clima de concordia: Cintia y Tarsis se amarán, serán felices y sobrevendrá un hijo común. Se imponen, especialmente a estas alturas, las leídas entre líneas que Ortiz recomendaba en su prólogo. ¿Escaparía realmente Pérez Galdós a ejercer la misión tutelar?
De modo que don Fernando necesita de un epílogo netamente americano, en que ya prescinde del texto primigenio para internarse en su discurso propio, sin perder el aura novelesca. Adoptará la forma epistolar y un simbolismo casi alegoría.

Se inicia con la Carta intima de América Andina a su hermana menor Juanita Antilla, fechada en Buenos Aires, significativamente, el 25 de mayo de 1910. La remitente se lamenta por la escasa comunicación entre ambas: «Estamos tan lejos y son tan tardíos los correos, ¡la familia está tan desparramada! Pero aunque con distinto apellido, hermanas somos al fin por parte de madre y justo es que nos queramos y contemos nuestras cosas» (Ortiz, ¿1911?: 321). Desde el principio ha establecido en su epílogo el concepto del iberoamericanismo, de su necesidad y llama a la unión.

Dice la hermana mayor: «Te supongo enterada por nuestro antiguo amigo Don Benito Pérez Galdós, quien a pesar de no conocernos de vista sabe de viejo nuestras penas y alegrías [...], de la nueva locura que se ha apoderado de Carlitos de Tarsis" (Ortiz, ¿1911?: 322). Añade que el guapo mozo se ha presentado por aquellas tierras, «rondándonos la reja, hablando nuestro lenguaje y diciéndonos palabritas más dulces que la miel» (Ortiz, ¿1911 ?: 323).

La carta de América Andina resulta así una llamada de alerta sobre el intento neoimperialista del panhispanismo, dirigida a Juanita Antilla, quien no pudo zafarse hasta muy tarde del autoritarismo maternal. Le cuenta de los celos de Tarsis ante otros pretendientes, en especial Samuel Johnson, y concluye atribulada: "Aconséjame tú. Dime si debo rendirme al infeliz enamorado, si he de despedir a mis amigos y admiradores, y si debo renunciar a mi rica libertad de rica hembra por una unión, casamentero antojo de nuestro pobre y alicaído primo» (Ortiz, ¿1911?: 329).

Diáfano en sus objetivos y preocupaciones, incluye don Fernando a continuación la réplica confidencial a la hermana mayor. Reveladoramente escrita en Baracoa y, no menos, el 4 de julio, la carta se inicia con $u n$ nunca olvidada hermana América y luego de felicitarse por haber recibido sus noticias, comenta: «Hoy estamos de fiesta y jolgorio por estos barrios con motivo del cumpleaños de un vecino muy bullanguero que tú
7

Cotejo: pág. 256.
De cómo Fernando Ortiz supo hallar una moza esquiva para cierto caballero encantado

RICARDO VIÑALET 

tiva puede hacerse de La reconquista... y de Entre cubanos..., por mencionar sólo dos ejemplos aludidos reiteradamente.
De cómo Fernando Ortiz supo hallar una moza esquiva para cierto caballero encantado

RICARDO VIÑALET conoces» (Ortiz, ¿1911?: 329). Juana, imbuida de espíritu identitario, refiere a su hermana: "Yo estoy en esta villa donde se meció mi cuna, porque a fuerza de oír hablar de mi raza y de mi linaje ardo en deseos de aprender las hazañas de mis mayores y aquí he venido y me tienes rebuscando pergaminos y cronicones de Indias que sirvan de pasto a las llamas de mi estudioso afán. Apenas encuentro nada, pero sólo el buscarlo ya es alivio en espera de goces que vendrán» (Ortiz, ¿1911?: 330).

Confiesa conocer del delirio de Tarsis porque también a ella la corteja ardientemente, tal cual hace además con el resto de las hermanas: « HHabrase visto sultán! Chica, ¡como se conoce que la sangre mora le bulle en las venas...!» (Ortiz, ¿1911?: 331). El donjuanesco primo no admite rivales, y ella no se sorprende por «toda la ojeriza que Carlitos le guarda a Sam, como por aquí llamamos al vecino» (Ortiz, ¿1911?: 331). Admite cierta simpatía por él, aun siendo también cortejador impenitente, ya que éste reúne cualidades distintas a Carlitos.

Aquí don Fernando procede a una evaluación de las diferencias entre ambos, que no pudieran entenderse descontextualizadamente. La España derrotada, caduca, inculta, analfabeta y pretenciosa era incapaz de reconquistar a América. Sobre el punto ya se ha tratado. Sólo desarrollándose pudiera establecer con Hispanoamérica relaciones de igualdad, respeto y beneficio mutuo. Mas la retórica panhispanista necesitaba llamar la atención acerca del peligro representado por Estados Unidos en lo cual, si bien -como se ha dicho- estaba implícita una actitud oportunista, no se equivocaba.

Fernando Ortiz entendió que una vía de prosperidad para la nación cubana sería factible, si se lograban nexos adecuados con ese país. Deseaba que Cuba pudiera emplear, en su necesario desenvolvimiento, posibilidades que se abrirían a tenor de vínculos con Estados Unidos.

Quizás haya sustentado entonces una consideración demasiado benevolente; tal vez en esos primeros años de república ilusoria no caló del todo en la esencia del pujante imperio, y pudo hasta concederle resquicios de bondad. Cierto es que ya diferentes voces se alzaban frente a la codicia yanqui, también lo es que, más tarde en su vida, ya Ortiz no se llamó a engaño, como lo prueban sus acciones y sus textos.

No quede, sin embargo, la idea de un hombre deslumbrado ni contemporizador con afán imperialista alguno, ni siquiera en 1910 , ese 4 de julio en que Juana le escribe a América Andina. Ella sabe de tres conceptos diferentes: la hermana, el vecino y el pretendiente. En El caballero encantado y la moza esquiva, en el resto de los materiales que integran La reconquista... y en muchos otros de ese período, don Fernando aquilató las actitudes procedentes de Washington en notable medida de su raigal esencia ${ }^{8}$.

Si Juana Antilla aconseja a América Andina de este modo: «Paliquea cuanto quieras con Carlos y hasta entretente con sus romanticismos, que no es malo mirar hacia atrás cuando sabemos mirar firmes hacia adelante; pero guárdate de permitirle irreverentes dichos, ni menos osadías comprometedoras» (Ortiz, ¿1911: 333), está delineando su posición ante el panhispanismo.

También quedará formulada la que asume ante el otro peligro. Expresa: «Así haré yo, si bien, naturalmente, más apegada que tú a $\mathrm{mi}$ amigo Sam por necesidades de más honda gratitud y próxima vecindad. Si por esto oyes decir a Carlos que he vendido mi honor, dile que miente, que pura sigo mi vivir honrado, alta y firme la mirada en el porvenir; angustiosa por la inexperiencia de mis pocos años, pero, resuelta a morir antes que retroceder un paso» (Ortiz, ¿1911?: 333).

Patriótico, digno, insobornable desde la otredad cubana frente a España y a Estados Unidos, esta versión libre de una novela es mucho más: constituye declaración identitaria y lección de ella. En última instancia, es grito del derecho a ser ante cualquier intento de absorción.

He aquí un modelo de re-escritura interpretativa sobre un texto literario, inducido por los misteriosos vasos comunicantes que fluyen entre la vida y el arte.

He aquí, de igual modo, el trazado de un destino histórico.

\section{BIBLIOGGRAFÍA Y REFERENCIAS}

AINSA, F. (1986): Identidad cultural de Iberoamérica en su narrativa, Editorial Gre-dos, Madrid, 591, págs. 
BLY, P.A. (1979): «Sex, egotism and social regeneration in Galdós El caballero encantado», Hispania, University of Cincinnati, U.S.A., The American Association of Teachers of Spanish and Portuguese, Inc., Vol. 2, March, Núm. 1, págs. 20-29.

BUENO, S. (1995): Aspectos literarios en la obra de Fernando Ortiz, conferencia pronunciada el 5 de octubre de 1995 en la Fundación La Naturaleza y el Hombre, inédita.

FRANCO, J.L. (1975): «A manera de Prólogo a la segunda edición de Los negros esclavos de Fernando Ortiz», Editorial de Ciencias Sociales, La Habana, págs. 9-11.

GARCÍA-CARRANZA, A. (1970): Bio-bibliografia de Fernando Ortiz, Instituto Cubano del Libro, La Habana, 250 págs.

- (1994): Fernando Ortiz. Suplemento, Biblioteca Nacional José MARTÍ, La Habana, 63 págs.

IBARRA, J. (1985): Un análisis sicosocial del cubano: 1898-1925, Editorial de Ciencias Sociales, La Habana.

MARTÍNEZ VILLENA, R. (1923): «Prólogo a En la tribuna: discursos cubanos, de Fernando Ortiz», tomo I, Imprenta El Siglo XX, La Habana, págs. VII-XVI.

MULLEN, E.J. (1987). «Los negros brujos: A Reexamination of the Text», Revista Cuban Studies, Center for Latin American Studies, University of Pittsburgh Press, Pittsburgh, págs. 111-129.

NOVÁS CALVO, L. (¿1949?): «Cubano de tres mundos». En: Miscelánea de estudios dedicados a Fernando Ortiz por sus discipulos, colegas y amigos, Vol. II, García, S.A., La Habana, 1956, págs. 1133-1141.

ORTIZ, F. (1895): Principi i prostes. Folleto de articulos de costumbres en dialecto menorquín, Ciudadela, Imp. Fábregas, 56 págs.

- (1901): Base para un estudio de la llamada reparación civil. Memoria para optar de doctor en Derecho, Librería de Victoriano Suárez, Madrid, 110 págs.

- (1905): Las simpatías de Italia por los mambises cubanos; documento para la bistoria de la Independencia de Cuba, Marsella, 72 págs.

- (1906): Los negros brujos. Apuntes para un estudio de etnologia criminal. Hampa Afro-Cubana. Carta-prólogo de Cesare
Lombroso, Editorial América, Madrid, ¿1917?, 406 págs.

- (1908): Para la agonografía española; estudio monográfico de las fiestas menorquinas, con un prólogo por Juan Benejam, Imprenta La Universal, La Habana, 41 págs.

- (1909): Los mambises Italianos; apuntes para la historia cubana, Imprenta Cuba y América, La Habana, 64 págs.

- (1910a): El caballero encantado y la moza esquiva. Versión libre y americana de una novela española de Benito Pérez Galdós, Imprenta La Universal, La Habana, paginación varia.

- (1910b): La reconquista de América; reflexiones sobre el panbispanismo, Librería P. Ollendorff, París, 352 págs.

- (1910c): Las rebeliones de los afrocubanos, La Habana, 112 págs.

- (1913a): Entre cubanos: psicología tropical, prólogo de Julio Le Riverend, $2^{\mathrm{a}}$ edición, Editorial de Ciencias Sociales, La Habana, 1987, 126 págs.

- (1913b): La Identificación dactiloscópica. Informe de policiología y de derecho público, seguido de las instrucciones técnicas para la práctica de la identificación y del decreto orgánico $N^{o} .1173$ de 1911, Imprenta La Universal, la Habana, 282 págs.

- (1914): Seamos boy como fueron ayer. Discurso leído el día 9 de enero de 1914 en la Sociedad Económica de Amigos del País, Imprenta La Universal, La Habana, 13 págs.

- (1915): La filosofía penal de los espiritistas; estudio de filosofía jurídica, Imprenta La Universal, La Habana, 126 págs.

- (1916): Los negros esclavos. Tomado de la primera edición: Hampa Afrocubana: Los negros esclavos. Estudio sociológico y de derecho público. A la edición se le han adicionado las notas encontradas en un ejemplar de Los negros esclavos perteneciente al archivo del autor, depositado en el Instituto de Historia de la Academia de Ciencias de Cuba. Además se le han agregado ilustraciones que aparecían en la edición original. Prólogo de José Luciano Franco, Editorial de Ciencias Sociales, La Habana, 1975, 525 págs.

- (1917a), Bases para la organización internacional de la solidaridad de los Estados ante la delincuencia. Informe leído ante la
De cómo Fernando Ortiz supo hallar una moza esquiva para cierto caballero encantado RICARDO VINAALET 
Segunda Sesión del Instituto Americano de Derecho Internacional, celebrada en La Habana en enero de 1917, Imprenta La Universal, La Habana, 8 págs.

- (1917b): Italia y Cuba. Publicado por acuerdo del Comité Cubano Pro Italia, La Habana, 32 págs.

- (1919), La crisis politica cubana. Sus causas y remedios. Resumen de un libro que ya no se escribirá, Imprenta La Universal, La Habana, 22 págs.

- (1922), Historia de la arqueología indocubana, Imprenta El Siglo XX, La Habana, 107 págs.

- (1923a): En la tribuna: discursos cubanos. Recopilación y prólogo por Rubén Martínez Villena, dos tomos, Imprenta El Siglo XX, La Habana, tomo I: 196 págs.; tomo II: 236 págs.

- (1923b): «El Dr. De la Torre y la crisis cultural». En su: En la tribuna: discursos cubanos, tomo II, Imprenta El Siglo XX, La Habana.

- (1923c): Un catauro de cubanismos; apuntes lexicográficos, Colección de Libros y Documentos Inéditos o Raros, Vol. 4, La Habana, 270 págs.

- (1924a): La filosofía penal de los espiritistas; estudio de filosofía jurídica, Biblioteca Jurídica de Autores Españoles y Extranjeros, Vol. 66, Ed. Reus, Madrid, 144 págs.

- (1924b): Glosario de afronegrismos; con un prólogo de Juan M. Dibigo, Imprenta El Siglo XX, La Habana, 554 págs.

- (1924c): La decadencia cubana; conferencia de propaganda renovadora pronunciada en la Sociedad Económica de Amigos del País la noche del 23 de Febrero de 1924, Imprenta La Universal, La Habana, 32 págs.

- (1926a): Proyecto de Código Criminal Cubano (Libro Primero o Parte General). Ponencia oficial con un proemio del autor, un juicio de Enrique Ferri y un apéndice con los primeros comentarios, Librería Cervantes, La Habana, 168 págs.

- (1926b): El derecho Internacional en el nuevo proyecto de código criminal cubano, Imprenta El Siglo XX, La Habana, 20 págs.

De cómo Fernando Ortiz supo hallar una moza esquiva para cierto caballero encantado

RICARDO VIÑALET
Washington, 5 de mayo de 1927», Revista Bimestre Cubana, Vol. XXII, julio-agosto, Núm. 4, la Habana, págs. 585-592.

- (1927b): «Las relaciones económicas entre los Estados Unidos y Cuba. Discurso en la American Chamber of Commerce of $\mathrm{Cu}$ ba, el 22 de junio de 1927», Revista Bimestre Cubana, Vol. XXII, julio-agosto, Núm. 4, La Habana, págs. 574-584.

- (1929): «Ni racismos ni xenofobias», $R e-$ vista Bimestre Cubana, Vol. XXIV, Núm. 1, enero-febrero, La Habana, págs. 6-19.

- (1936): "Cómo pensaba yo hace treinta años», Revista Ultra, Vol. I, Núm. 2, agosto, La Habana, págs. 167-172.

- (1940): «Cuba es un ajiaco», La Nueva Democracia, Nueva York, Núm. 11, noviembre.

- (1946): El engaño de las razas, Editorial de Ciencias Sociales, $2^{a}$ edición, La Habana, 441 págs.

- (1955): «El Panhispanismo», Revista Bimestre Cubana, Vol. LXX, Núm. 1, enerodiciembre, La Habana, págs. 55-59.

- (1996): Fernando Ortiz y la cubanidad. Selección y prólogo de Norma Suárez, Colección La Fuente Viva, Fuildación Fernando Ortiz, Ediciones Unión, la Habana, 43 págs.

RIVEREND, J.L. (1987): «Prólogo a la segunda edición de Entre cubanos: psicología tropical, de Fernando Ortiz, Editorial de Ciencias Sociales, La Habana, págs. VXIII.

Pérez Galdós, B. (1909): El caballero encantado. Edición, prólogo, bibliografía general y bibliografía sobre «El caballero encantado», de Julio Rodríquez Puértolas, Ediciones Cátedra, Madrid, 1977, 345 págs.

- (1909): «El caballero encantado». En: Obras completas de [...], Aguilar, Madrid, tomo VI, 1951, págs. 223-343. (F.C. Sainz de Robles tuvo a su cargo la introducción, biografía, notas y censo de personajes galdosianos en este edición).

ROVIRA, J.C. (1992): Identidad cultural y literatura. Antología de pensamiento bispanoamericano, tomo VII, Instituto de Cultura Juan Gil-Albert y Comisión V Centenario, Generalitat Valenciana, Alicante, 236 págs.

SAÍN DE ROBLES, F.C. (1951): «Nota preliminar a El caballero encantado». En: 
Obras completas de Benito Pérez Galdós, tomo VI, Aguilar, Madrid, pág. 221-223.

SCHULMAN, L. (1996): «Introducción a The Autoblography of a Slave. A Bilingual Edition. Introduction and modernized version by Ivan A. Schulman. Transiated by Evelyn Picon Garfield. Latin American Literature and Culture Series, Wayne University Press, Detroit, 135 págs.

UNAMUNO, M. de (1996): Epistolario americano (1890-1936). Edición, introducción y notas de Laureano Robles, Ediciones Universidad de Salamanca, 306 págs.
VIÑALET, R. (1984): Temas de literatura española, tomo II, Editorial Pueblo y Educación, La Habana, 336 págs.

- (1996a): «Entre cubanos y el regeneracionismo", Revista La Gaceta de Cuba, La Habana, Año 34, Núm. 2, marzo-abril, págs. 27-29.

- (1996b): «De Miguel de Unamuno a Fernando Ortiz, dos cartas presumiblemente inéditas", Revista La Gaceta de Cuba, La Habana, Año 34, Núm. 6, noviembre-diciembre, págs. 40-41. 


\begin{abstract}
Ambrosio Fornet
Ensayista, crítico literario, escritor y guionista de cine, publicó su primera obra de creación en 1958 (A un paso del diluvio, cuentos). Se inició en la crítica literaria con el volumen de reseñas titulado En tres $y$ dos (1964) y con el ensayo En blanco y negro (1967), sobre la cuentística cubana hasta 1959. Entre sus principales obras sobresalen la Antología del cuento cubano contemporáneo (1967), la recopilación Cuentos de la Revolución Cubana (1971), y Alea: una retrospectiva crítica (1987). Ha publicado también El libro en Cuba (1994), un minucioso estudio sobre la imprenta en la época colonial que abre nuevas perspectivas para una sociología de la literatura cubana en este siglo.
\end{abstract}

\section{1}

Compárese, además, con el del Manifiesto comunista (1848), donde se describe la nueva dinámica que introduce la burguesía en todos los aspectos de la vida material y espiritual.
En la encrucijada del fin de siglo AMBROSIO FORNET

\title{
EN LA ENCRUCIJADA DEL FIN DE SIGLO
}

\author{
AMBROSIO FORNET
}

\section{1}

Permítanme comenzar con algunas precisiones. El tema que tengo asignado es el de la literatura y el pensamiento cubanos de finales del siglo diecinueve. Esto me plantea ciertos problemas metodológicos, relacionados con la posible periodización de esa compleja etapa. Recuerden que Cuba fue colonia española hasta 1898, destino que en América compartió con Puerto Rico. Las autoridades colonialistas solían llamar a Cuba «la siempre fiel» pero lo cierto es que la Isla era bastante díscola. En un lapso de veintisiete años, entre 1868 y 1895 , los cubanos desataron tres guerras por la independencia, la primera de las cuales duró diez años. Todo el pensamiento cubano y una buena parte de su producción simbólica estuvieron determinados desde entonces, directa o indirectamente, por las posiciones políticas que se asumían con respecto al status colonial: de un lado, los separatistas (unos aspirando a la total independencia, otros, a la anexión a los Estados Unidos), y del otro, los autonomistas, que abogaban por permanecer unidos a España, pero bajo un régimen de libertades cuyo modelo era el tipo de self-government imperante en Canadá (lo que por cierto lograron en enero de 1898, cuando ya era demasiado tarde). En los Materiales de Consulta que les hemos entregado encontrarán ustedes un resumen de esas posiciones bajo el título de «Saco o Martí: evolución o revolución». Tal vez la historia íntegra del pensamiento cubano en el siglo diecinueve pueda resumirse en esos dos nombres y esas dos alternativas. $\mathrm{Pe}-$ ro no debe olvidarse que en este drama co- lectivo hay un convidado de piedra: el esclavo. Todo lo que se dice o hace en la Cuba colonial tiene que ver con la posición que se asume, primero, ante la esclavitud, y después de su abolición, en 1886, ante el papel que las masas de ex-esclavos y de ciudadanos negros y mestizos podían desempeñar en la vida pública. Es lo que he llamado en otra parte, refiriéndome a José Antonio Saco, la pesadilla de los censos, el horror de los datos demográficos.

Contra ese telón de fondo podríamos hacer un primer intento de periodización. Desde una perspectiva estrictamente histórica -o política, si lo prefieren-, el fin de siglo cubano abarcaría un período de diecisiete años, el que va desde 1878 , en que termina la primera guerra, hasta 1895 , en que comienza la tercera. Entre ambas fechas habría un momento clave, 1887 , en que se decreta la llamada libertad de imprenta, tanto para Cuba como para Puerto Rico. Ahora bien, desde una perspectiva estrictamente literaria, el lapso podría reducirse a once años e iniciarse en 1882. En este instante crucial para la literatura cubana -e hispanoamericana, inclusiveaparecen Cecilia Valdés, de Cirilo Villaverde - la gran novela cubana del siglo- y el poemario Ismaelillo, de José Martí, que para muchos es el texto fundacional del Modernismo. A ellos habría que añadir un prólogo que Martí escribe ese mismo año y que se considera casi unánimemente el primer manifiesto del naciente movimiento literario'. Si hiciéramos culminar el período, como ya dije, once años después -es decir, en 1893, fecha en que aparecen Leonela, de Nicolás Heredia, la última novela significativa del siglo, y Bustos y 
rimas, de Julián del Casal - estaríamos abarcando en ese lapso un impresionante corpus que, en diferentes géneros, incluiría tres novelas insólitas en el contexto de nuestra narrativa: Amistad funesta (1885), de Martí - la extraña irrupción del esteticismo en la literatura hispanoamericana-, Mi tío el empleado (1887), de Ramón Meza —una sátira política que, con Cecilia Valdés, forma el dúo de las grandes novelas cubanas del siglo-y la sátira filosófica Aventuras de las hormigas (1888), de Esteban Borrero Echeverría. Otras referencias obligadas del período serían $L a$ Edad de Oro (1889), revista para niños redactada íntegramente por Martí, sus Versos sencillos (1891), casi toda la obra literaria y periodística de Casal, la novela Sofía (1891), de Martín Morúa Delgado, y por último, aunque no en orden de importancia, las primeras muestras de la literatura de campaña que circularon libremente en la Isla, así como gran parte de la obra de los más notables ensayistas y críticos del siglo. No es poco decir. Superponiendo ambos esquemas cronológicos y extendiéndolos hasta el fin de la dominación española, tendríamos una parábola histórica y literaria sumamente representativa, ese lapso de dos décadas (1878-1898) que marca el fin de dos guerras y que nos permitiría incluir entre los textos otras muestras de la literatura de campaña, incluyendo su máximo exponente, el último Diario de Martí. La existencia de textos de esta naturaleza, por cierto - «la historia narrada por sus creadores», como la llamó Max Henríquez Ureña, de hecho una literatura otra, casi siempre excluída del canon - plantea problemas de otra índole a la hora de las clasificaciones y periodizaciones. Al igual que una parte del corpus al que hemos venido refiriéndonos, esa producción testimonial no siempre operaba en el ámbito cultural de la Isla - y por tanto no siempre incidía sobre su dinámica interna-, dado que se escribía o publicaba en las zonas rurales, por los combatientes, o en el extranjero, por los emigrados y exiliados. Hasta ahora estas bifurcaciones han sido una constante en la historia de nuestra literatura, aunque el signo ideológico de los textos respectivos, como es natural, difieran según las circunstancias.

Una última reflexión sobre el carácter de nuestra empresas: ¿Es posible hablar de pen- samiento y literatura como categorías distintas y excluyentes? ¿O es que estamos pensando en bellas letras, por un lado, y por el otro en ese tipo de prosa expositiva y reflexiva que se expresa a través de géneros como el ensayo y la crítica? Ya las inquisiciones de Gaos y sus discípulos pusieron de manifiesto que en nuestra América, más que filósofos propiamente dichos, había pensadores, cuyas reflexiones, por cierto, tendían a girar obsesivamente en torno a temas como el de la Identidad, tanto nacional como cultural. Pero habría que añadir que desde los Comentarios Reales, del Inca Garcilaso, hasta el Canto general, de Neruda y El siglo de las luces, de Carpentier, el pensamiento americano no siempre fluye por los cauces tradicionales del artículo y el ensayo. En nuestro caso bastaría pensar en Martí y Casal para ver cuánto hay de «poético» o «artístico» en sus textos narrativos y expositivos, y cuánto de reflexividad en sus versos. Esa compleja red de influencias recíprocas, ese fluido sistema de vasos comunicantes nos impide caer en la tentación de los deslindes categóricos. Algo semejante nos ocurre con la definición del Modernismo, asunto tan polémico como manoseado, pero que no vamos a soslayar. Si pudiéramos tapar el sol con un dedo, haciendo caso omiso de Martí y de Casal, nuestra tarea sería mucho más sencilla, pero también mucho menos estimulante.

\section{2}

Federico de Onís precisó en su momento que el Modernismo no era un movimiento literario sino el espíritu de una época de crisis, y que no tenía sentido disociarlo categóricamente de la modernidad puesto que ésta era, justamente, su aspiración suprema. Alfredo Roggiano, por su parte, lo calificó como
En la encrucijada del fin de siglo AMBROSIO FORNET 


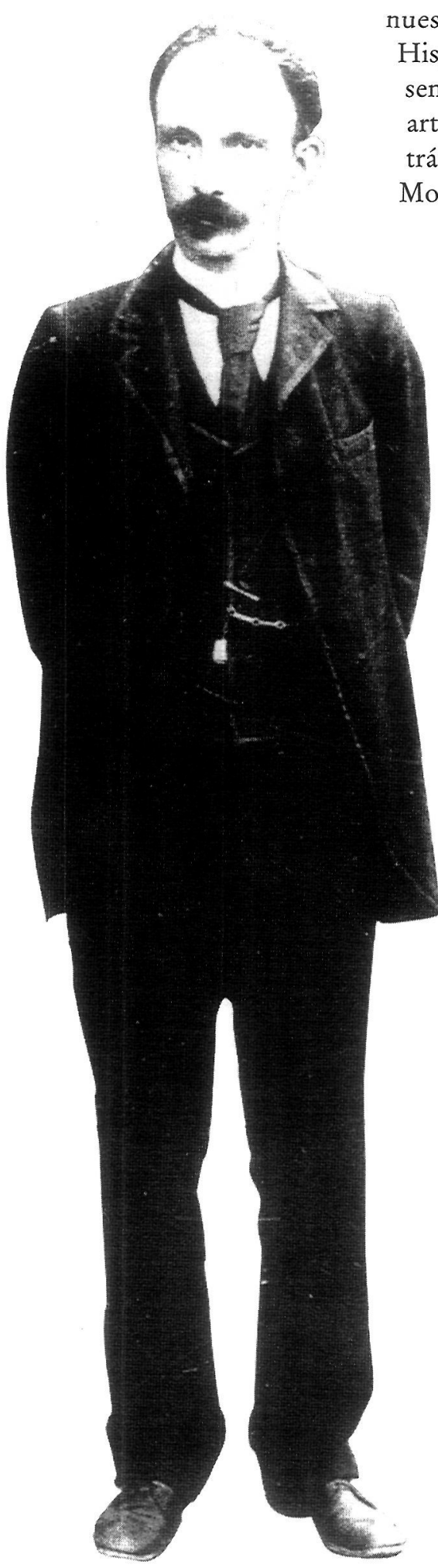

José Martí.

En la encrucijada del fin de siglo AMBROSIO FORNET nuestro Renacimiento: tuvo para Hispanoamérica - dijo- -el mismo sentido de crisis histórica, cultural y artística» que tuvo para Europa el tránsito de la Edad Media a la Edad Moderna. Permítanme introducir en esos juicios un matiz importante, $y$ es que en este caso se trataba de una modernidad «periférica» - para usar un término acunado por Beatriz Sarlo-y sujeta, por tanto, a contradicciones profundas. $\mathrm{Me}$ interesa subrayar, además - ya que nos atañe directamente- que en esta época la tradicional antinomia civilización/barbarie fue siendo desplazada por la de cultura/civilización a medida que los emblemas del progreso material, los deslumbrantes signos del desarrollo técnico, aparecían contaminados de un salvajismo de nuevo cuño. Ahora la «civilización» no se contraponía a la barbarie únicamente, sino también a la cultura entendida como expresión de valores humanos y reducto de la memoria colectiva. (Por lo demás, este enfoque radical tenía profundas raíces en aquella modalidad del pensamiento latinoamericano cuyo eje era el sentido de la justicia. Baste recordar al chileno Francisco Bilbao: ${ } \mathrm{O}$ h, civilización, que se confunde con la moda hasta hacer que sea moda despreciar lo justo!» [El Evangelio americano, 1864]). El emblema visible de esa contradicción era el nuevo espacio urbano, la metrópolis moderna. En relación con ella encontramos, de un lado, la tajante afirmación de Casal, de clara estirpe bandeleriana: "Tengo el impuro amor de las ciudades, $/ y$ a ese sol que ilumina las edades/prefiero yo del gas las claridades». Y del otro, las desgarradoras protestas de Martí en Flores del destierro y en poemas como
«Amor de ciudad grande», de Versos libres: «Se ama de pie, en las calles, entre el polvo/de los salones y las plazas (...) ¿Qué es lo que falta/ que la ventura falta?». Permítanme una digresión: no ha de verse, en la confesión de Casal, una simple muestra de esnobismo hoy diríamos de mimetismo cultural-, sino la expresión sublimada de un conflicto profundo. Hoy sabemos que el esteticismo de los poetas era en parte una respuesta desafiante al mercantilismo de la burguesía, y en parte una dramática expresión de sus aspiraciones cosmopolitas. Como bien observa Octavio Paz, aludiendo al galicismo mental del primer Darío y sus epígonos: los modernistas no querían ser franceses, sino modernos, y no despreciaban a América, sino que aspiraban a situarla a la altura de París y de Londres. Martí vivió la experiencia de la modernidad en Nueva York, donde residió durante quince años, de 1880 a 1895, justamente la etapa en que la ciudad empezó a convertirse, desde el punto de vista del desarrollo urbano, en el epicentro del Nuevo Mundo. Pudo ver cómo se establecían allí la primera red telefónica y los elevadores eléctricos; cómo los carros tirados por caballos, que transitaban a una velocidad de seis millas por hora, cedían su lugar a los tranvías eléctricos que quintuplicaban esa velocidad y trasladaban el triple de pasajeros. Pudo ver cómo las avenidas y los bulevares se iluminaban, convirtiendo la noche en día y atrayendo al paseante - al flaneur de que habla Benjamin - hacia el espectáculo de las vidrieras y los placeres de la vida nocturna. Y pudo ver, sobre todo - en el corazón mismo de la ciudad y en los flamantes parques de diversiones - lo que medio siglo después $\mathrm{Ka}$ rel Reisman llamaría la «muchedumbre solitaria», esa otra cara de una «civilización» concebida casi exclusivamente en términos positivistas y pragmáticos. En su ensayo sobre Baudelaire, Benjamin cita una curiosa observación de Georg Simmel sobre el nuevo tipo de relaciones humanas que se establecen -o dejan de establecerse- en la gran ciudad: "Antes del desarrollo de los autobuses, de los trenes y de los tranvías en el siglo XIX - dice Simmel-, las gentes no se encontraron en la circunstancia de tener que mirarse mutuamente largos minutos, horas incluso, sin dirigirse la palabra unos a otros». 
En una crónica periodística sobre Coney Island, que hoy forma parte de sus Escenas norteamericanas, Martí describe como laberintos u hormigueros los recovecos de ese parque de diversiones neoyorkino donde se pierden las multitudes anónimas, ávidas de entretenimiento y novedad. (Por cierto, Julio Ramos considera esa crónica «una reflexión sobre el surgimiento de la cultura de masas», hecha desde la perspectiva crítica de un letrado). Martí volverá una y otra vez al tema en sus versos, sus crónicas y su célebre ensayo «Nuestra América» (1891). Ahora la ciudad no es vista como un fenómeno aislado sino como un centro hegemónico, que opera en detrimento de su periferia. En efecto, Martí se refiere a la «soberbia de las ciudades capitales», al odio o el desdén con que la ciudad mira al campo. Se trata de un enfrentamiento entre dos partes complementarias del organismo social, una de las cuales, sin embargo, envuelta en las banderas del Progreso, se niega a reconocer la legitimidad de la otra. En semejante situación, los países hispanoamericanos se ven forzados a imitar, o a la inversa, impedidos de crear, porque esto sólo es posible partiendo de las propias fuerzas, cuyo costado más autóctono, en este caso, se desestima. «Eramos una máscara - dice Martí, aludiendo a la imagen que de sí mismos proyectaban los sectores letrados de Hispanoamérica-, con los calzones de Inglaterra, el chaleco parisiense, el chaquetón de Norteamérica y la montera de España». Pero la realidad desautorizaba o burlaba una y otra vez esos refinados o grotescos simulacros: «[E]1 libro importado ha sido vencido en América por el hombre natural. Los hombres naturales han vencido a los letrados artificiales. El mestizo autóctono ha vencido al criollo exótico. No hay batalla entre la civilización y la barbarie, sino entre la falsa erudición y la naturaleza». Diez años antes, aludiendo al pesimismo de salón que habían puesto de moda ciertos poetas franceses, Martí lo atribuía a una variante del mercantilismo muy propia de las ciudades opulentas, o para decirlo con sus propias palabras, a «literatos sin empleo en la ciudad sobrada de literatura». Conviene añadir esta visión iconoclasta de lo «moderno» — así como aquella doble concepción antropológica y democrática de la cultura - al acervo del pensamiento cubano de fines de siglo, para colocarlas junto a los elementos estéticos y políticos más conocidos del legado intelectual martiano: la renovación poética, el antiimperialismo, el anti-racismo, la concepción de una república «con todos y para el bien de todos».

\section{3}

Todo lo que pudiera yo agregar sobre el modernismo y el papel que en éste desempeñaron Martí y Casal, ha sido dicho de manera más precisa y aguda por diversos autores ${ }^{2}$. Como ejercicio crítico les propongo que hagan ustedes un análisis comparativo de tres poemas de temática semejante: «Salomé» (Nieve), de Casal, «La bailarina española» (Versos sencillos), de Martí, y «Elogio de la seguidilla» (Prosas profanas), de Darío. Es algo que nadie ha hecho todavía, hasta donde alcanzo a saber. No insinúo precedencias, diferencias ni similitudes porque en eso consiste el ejercicio, justamente: en que ustedes lo descubran por su propia cuenta.

El período de entreguerras (1878-1895) ha sido calificado por Vitier como «la etapa de mayor esplendor de la crítica cubana», una afirmación avalada por los nombres de Enrique José Varona, Enrique Piñeyro, Manuel Sanguily, Rafael María Merchán, Emilio Bobadilla (Fray Candil) y Manuel de la Cruz, para no citar a los novelistas y poetas que incursionaron ocasionalmente en la crítica. Imposible, en el escaso tiempo de que todavía disponemos, enumerar sus obras o intentar una valoración de sus aportes a nuestro movimiento intelectual, o más aún, detenernos en algunas particularidades de sus respectivas trayectorias, debidas en parte al campo cultural en que se movieron (Piñeyro radicaba en París, Merchán en Bogotá, Fray Candil en Madrid...). El género cuenta también con un anecdotario que incluye casos de desapariciones prematuras e iniciaciones precoces: el de Aurelio Mitjans, por ejemplo, autor de una imprescindible historia de la literatura cubana, que murió a los veintiseis años de edad; o el de José de Armas y Cárdenas (Justo de Lara), que a los dieciocho años se situó entre los primeros cervantistas de Hispanoamérica con la obra El Quijote de Avellaneda y sus críticos (1884). Ahora bien, la gran tarea de la intelectualidad cubana de la
2

Los estudiantes, disponen de dos excelentes compilaciones: José Marti: historia y literatura ante el fin del siglo XIX (Universidad de Alicante/Casa de las Américas, 1997) y Modernismo y modernidad en el ámbito hispánico (Universidad Internacional de Andalucía/Asociación Española de Estudios Literarios Hispanoamericanos, 1998), la primera editada por Carmen Alemany, Ramiro Muñoz y José Carlos Rovira, y la segunda por Trinidad Barrera. Puede consultarse también con provecho la compilación de Sonia Mattalía Modernidad y fin de siglo en Hispanoamérica. Alicante, Instituto de Cultura Juan Gil-Albert, 1996.
En la encrucijada del fin de siglo AMBROSIO FORNET 
época tenía un carácter eminentemente político: la formación de la conciencia nacional. Y serían los críticos separatistas - algunos de ellos, como Sanguily, destacados luchadores por la independencia - los que se mostrarían más aptos para llevar a cabo la empresa, sobre todo después de 1887 , cuando pudieron hacerlo dentro de los marcos legales. El Imaginario específico de la nación - como entidad histórica no sólo diferenciada de España sino enfrentada a ella- iba a ser construido a través de la memoria colectiva, la crítica al sistema colonial y la rivalidad o la alianza táctica con los autonomistas, que ofrecían tribunas respetables para la agitación política. Se trataba de un arduo proceso de descolonización ideológica que debía comenzar por el reconocimiento tanto de los valores propios como de la aptitud de los criollos mismos para el ejercicio del gobierno independiente. El nivel de autoestima en que se hallaban aquéllos en vísperas de la Guerra de los Diez Años puede calcularse por el comentario de un escritor costumbrista, Luis Victoriano Betancourt, para quien la tradicional afición de los cubanos a la danza revelaba su incapacidad para sumarse a la corriente del progreso: «El gas alumbra - decía-, el vapor ruge, la electricidad truena y nosotros bailamos». Una guerra prolongada, escenario de hazañas increíbles —en la que el propio Betancourt participó desde el principio- sirvió de base para la construcción de un sujeto nacional inspirado en los arquetipos de la épica. Fuera de Cuba, Martí fue uno de los primeros artífices de esa imagen. En Cuba lo fueron Sanguily y, sobre todo, $\mathrm{Ma}-$ nuel de la Cruz, cuya obra Episodios de la Revolución cubana (1890), relatos basados en el testimonio oral de los excombatientes, sirvió para mostrar al lector ese aspecto hasta entonces ignorado de su historia y de su propia naturaleza.

Lo curioso es que la ideología política acabó determinando hasta las preferencias estéticas y metodológicas de los críticos independentistas. Estos - y permítanme repetir aquí, más o menos textualmente, lo que dije en otra ocasión- mostraron su partidismo mediante el sencillo expediente de negarse a pensar en español. En efecto, eligieron como mentores intelectuales a los teóricos franceses - Taine, Guyau, Bouget, Lemaître...- para poner en evidencia no sólo que rechazaban la posible tutela intelectual de España sino también que reivindicaban el derecho de juzgar el pensamiento español «a la francesa», como expresión de un escolasticismo démodé. Para ellos se trataba de una lucha entre la reacción y el progreso, o personalizando, entre el lúcido Taine - representante de «la crítica con fundamento científico», como decía Cruz-y el iracundo Menéndez Pelayo, en quien Sanguily veía encarnarse «ese espíritu español ardoroso, clerical, fanático». Cruz se atrevió a afirmar que el pensamiento cubano, de vieja filiación anglo-francesa - cartesiano, sensualista, spenceriano... - se había emancipado totalmente de «la patria potestad del intelecto español». «La inteligencia española, atrofiada por la teología - comentaba-, no cuenta en las influencias generadoras de la inteligencia cubana». La tendencia produjo uno de sus ejemplos más notables en La sensibilidad en la poesía castellana (1898), de Nicolás Heredia, quien intentó demostrar que entre los poetas españoles la víscera que menos trabajaba, según sus propias palabras, era el corazón. «Desde Herrera hasta Quintana -decía, con una frialdad que a duras penas lograba ocultar su hispanofobia - se escucha el ruido armonioso de una lengua bien rimada, pero pocas veces se nota el latido de una emoción sentida con calor y expresada con verdad».

Quisiera proponerles otro ejercicio, para terminar, relacionado esta vez con las dos novelas más significativas del período, Mi Tío el empleado y Leonela. En la primera, un palurdo llamado Vicente Cuevas llega a Cuba sin un céntimo en el bolsillo y, gracias a diversos factores - todos relacionados con los distintos niveles de corrupción que prevalecen en el mundo colonial - acaba regresando un buen día a España con un título nobiliario, una fortuna personal y una bella y acaudalada criolla. En la segunda, el ingeniero John Valdespina -nacido en Cuba pero educado en los Estados Unidos- se establece en una zona rural de la Isla con el propósito de construir un ferrocarril por cuenta de la compañía minera Smithson Bros. Como parte de su misión, funda un pequeño pueblo, Smithson City, «algo nuevo, exótico, fuera del medio ambiente tropical», semejante a «uno de esos graciosos caseríos de las márgenes del Hudson» que podían verse en las cercanías de Nueva York. To- 
do es borrado de golpe por el torbellino de la guerra. Valdespina, además, es víctima de un equívoco trágico relacionado con la pasión que suscita en dos hermanas gemelas, idénticas entre sí. Mi pregunta es la siguiente: ¿no se tratará, en ambos casos, de variaciones sobre el tema civilización/barbarie, metáforas sobre la imposibilidad de la modernización en el mundo colonial o en sistemas donde sobrevi- van, más o menos encubiertas -para decirlo con palabras de hoy- las estructuras coloniales o neocoloniales, típicas del mundo subdesarrollado? ¿Tendrá el Primer Magistrado de El recurso del método algún parentesco remoto con Vicente Cuevas? ¿Será John Valdespina uno de los antepasados del Santos Luzardo de Doña Bárbara? 


\title{
Mario Benedetti
}

Escritor uruguayo. Es autor de unos ochenta libros de poesía, novela, relatos, ensayo, teatro, y uno de los escritores más leídos de la literatura en español. Exiliado de Uruguay en 1973, residió en Cuba y trabajó en Casa de las Américas, y luego en España, hasta que en 1985 regresa a su país. Está fuertemente vinculado a la Universidad de Alicante, de la que es Doctor Honoris Causa desde 1997, y en la que existe un Centro de Estudios Iberoamericanos que lleva su nombre.

\section{POESÍA CUBANA DEL SIGLO XX: UN VISTAZO PERSONAL Y SELECTIVO}

\author{
MARIO BENEDETTI
}

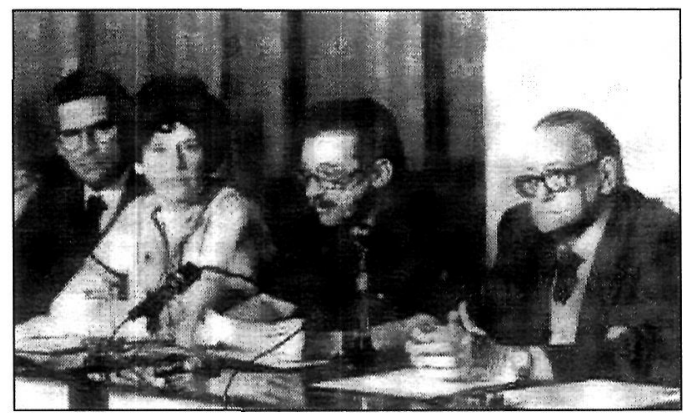

Mario Benedetti con Haydeé Santamaría y Alejo Carpentier en la Casa de las Américas (1978).
Con el perdón de ustedes empezaré citándome. Hace unos diez años escribí que, al igual que en otras regiones del mundo, y dentro del ya bastante marginado oficio literario, la poesía seguía siendo, en América Latina, un quehacer periférico. Es cierto que sobre la poesía pesa la maldición consumista de que se trata de un artículo que no se vende, $\mathrm{y}$ en consecuencia, ya que vivimos encorsetados por los prejuicios y alergias del mercado y sus tecnócratas, los editores suelen llegar a la conclusión de que no vale la pena gastar un centavo en la promoción de una mercadería tan poco redituable. Ese desapego produce sin embargo un fenómeno curioso, sobre todo si se lo compara con los mecanismos de divulgación que se aplican a la novela. Gracias a los avisos en cadena, al impulso persuasivo de los grandes almacenes, a las arbitrarias y pactadas nóminas de libros más vendidos (en las que jamás aparece un libro de poesía) y otras maniobras que van comprometiendo los efectos condicionados del consumidor, alrededor de la novela se van moldeando los gustos del gran público. Por el contrario, en el caso de la poesía son los lectores, así no abunden, quienes se arriman espontáneamente a ella.

No hace mucho, el crítico Rafael Conte señalaba que en España el mercado poético es pequeño, casi inexistente, y se refugia entre los poetas y profesores, ya que los medios de comunicación expulsan de su seno a la poesía. Y agregaba: «Y sin embargo, sin la poesía no hay nada. Los surrealistas se adelantaron a la vanguardia, los poetas latinoamericanos al boom de la nueva novela de aquel continente, los poetas sociales españoles a la narrativa social y los novísimos a la nueva novela. La poesía es el centro, el crisol, el espacio mágico en el que se produce la literatura verdadera, aunque nadie parezca enterarse de ello. Todo lo demás es -somos- resultados».

Hasta aquí Rafael Conte. No obstante, es paradójicamente esa indefensión profesional la que tal vez otorgue más independencia al autor de poesía que a los cultores de otros géneros. Por lo menos no es frecuente que el poeta tenga editores que lo apremien ni tentadoras ofertas que lo perturben. También es cierto que, ante esa falta de eco, el poeta corre el riesgo de que lo invada el tedio, pero no hay que olvidar que, como escribió Bergamín, «el aburrimiento de la ostra produce perlas».

En la poesía puede haber invención, no autoengaño; puede haber influencia, no contagio. Es el género de la sinceridad última, irreversible. Un poema puede ser luminoso como en Eliseo Diego u oscuro como en Lezama Lima, pero si ambos son genuinos es porque, bajo la claridad del uno o las tinieblas del otro, hay un denominador común: el entrañable fluir de los sentimientos, las convicciones y las búsquedas.

No hay veredicto en profundidad sin concurrencia de la poesía. La marginalidad a que se la somete le otorga una libertad incanjeable. Contradiciendo a todos los arúspices, ni la novela ni la poesía morirán, pero sus rumbos, aunque a veces se crucen y recíprocamente se influyan, son diversos. A la novela la llevan en andas. La poesía, en cambio, ha aprendido a valerse por sí misma, a preguntar, aunque na-
Poesía cubana del siglo XX: MARIO BENEDETTI 
die le responda; a responder, aunque nadie le pregunte.

Refiriéndonos ahora por fin a la poesía cubana, quizá valga la pena recordar algo tan obvio como que Cuba es una isla. $Y$ como isla que es, no sólo está rodeada por mares a menudo inescrutables, pródigos en invasiones y tentaciones, sino también por corrientes literarias, de pujanzas y vislumbres varias. Siempre me ha sonado como una revelación un hallazgo del poeta brasileño Oswald de Andrade, que en los años treinta creó ( $y$ aplicó) su teoría de la antropofagia, nombre con el que designó, según Haroldo de Campos, «la aceptación no pasiva, sino bajo la forma de una devoraçao crítica de la contribución europea, y su transformación en un producto nuevo, dotado de características propias, que, a su vez, pasaba a tener una nueva universalidad, una nueva capacidad de ser exportado a todo el mundo».

Haroldo de Campos aplicaba, por supuesto, su teoría a la literatura de su país, pero, de los otros países de América Latina, tal vez sea Cuba el que más se aproxima a ese extraño viaje de ida y vuelta. A diferencia de lo ocurrido en otras regiones de la América precolombina, Cuba (o lo que más tarde se llamó Cuba) no recibió a los invasores con una cultura autóctona, pero sí fue asimilando la que éstos, de manera espontánea o a regañadientes, le fueron dejando. No olvidemos que el primer poema cubano, Espejo de paciencia (1608), no lo escribió un cubano, sino un español, Silvestre de Balboa, nacido en Gran Canaria en 1503 y que llegó a ser escribano del cabildo en Puerto Príncipe. También hay que destacar que con los conquistadores no sólo vinieron blancos, sino también negros, y que entre unos y otros producirán luego la amalgama del mulato, cuyo máximo exponente será mucho más tarde Nicolás Guillén. A partir de 1959, la vitalidad de la Revolución sacudió no sólo a los jóvenes, sino también a los veteranos. La transformación del contorno trajo para el poeta, entre otras cosas, la afortunada consecuencia de una renovación de imágenes. En la poesía de Guillén, por ejemplo, los últimos años de exilio habían ido transformando la alegre bronca en gris resentimiento, pero luego, ya en su medio natural, cómodo en su color, instalado en la revolución que figuró siempre entre sus amores a conquistar, Guillén rejuveneció, recuperó su bienhumorada manera de imáginar, y creó esa experimental travesura que es $E l$ gran Zoo.

Guillén redescubre el son (enraizado en el son musical) para la poesía cubana. Títulos de sus libros (Motivos de son, Sóngoro cosongo, El son entero) son apenas señales de esa asunción. El ritmo, las repeticiones, el buen humor del son, invaden la poesía de Guillén y le otorgan voz propia, pero también le dan color a su soledad:

La palma que está en el patio, nació sola;

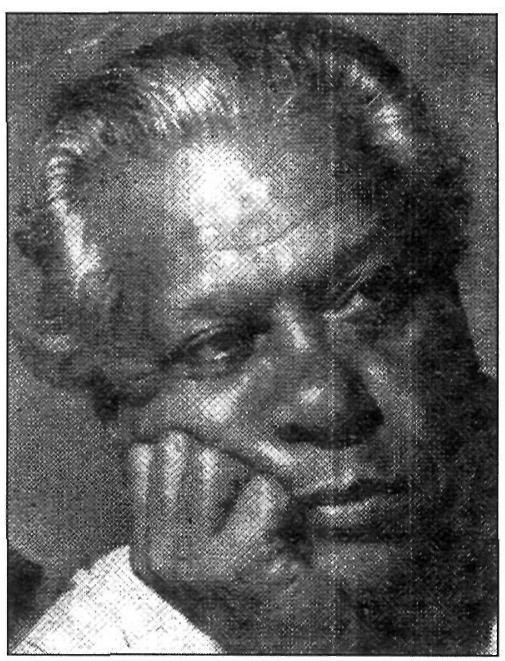

Nicolás Guillén.

creció sin que yo la viera, creció sola; bajo la luna y el sol, vive sola.

Otras veces conserva, vibrante, la precisión del original:

Sóngoro, cosongo,
songo be;
sóngoro, cosongo
de mamey

En el vasto espacio que media entre los nombres ineludibles de Martí y Guillén hay varias promociones poéticas que no es posible analizar en un vistazo tan somero como éste. Baste mencionar a Julián del Casal (18631893), que no es exactamente lo contrario sino más bien lo distinto de Martí y que muere a los treinta años, cuando tanto cabía esperar de su estro melancólico.

Pero en el siglo XIX quedan, entre otras, las sombras tutelares de José María Heredia (1803-1839), que llena de cubanía los temas de la mujer, la patria y el destierro; Plácido, o sea Gabriel de la Concepción Valdés (1809-1844), modesto y talentoso precursor de la poesía cotidiana, que muere fusilado a los 35 años; José Jacinto Milanés (1814-1863), con su entrañable descripción del paisaje pero también con su enfermiza obsesión por la pureza, que acabó precipitándolo en la demencia (como acontecería más tarde con Manuel de Zequeira); los nativistas Francisco Pobeda (17961881) y El Cucalambé, o sea Juan Cristóbal Nápoles Fajardo, nacido en 1829 y suicidado o asesinado o simplemente desaparecido en fecha ignota, autor de un formidable soneto-
Poesía cubana del siglo XX: un vistazo personal y selectivo MARIO BENEDET'TI 


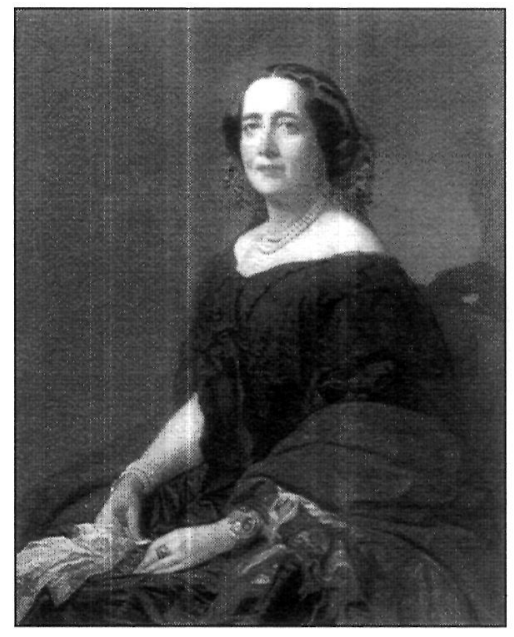

Gertrudis Gómez de Avellaneda.

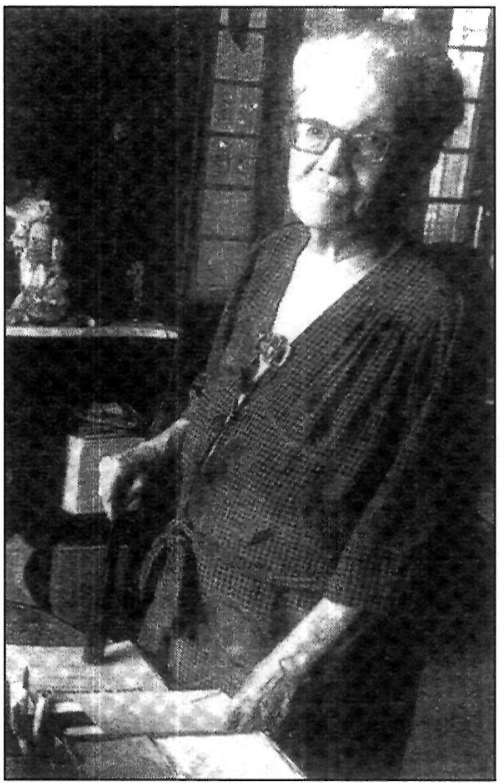

Dulce María Loynaz. autorretrato, obrita maestra de la picaresca cubana:

Tengo, señores, el cabello rubio, una frente en que cabe un buen escaño, $\mathrm{y}$ dos ojos que son, si no me engaño del color de las llamas del Vesubio.

Es larga mi nariz como el Danubio, mis orejas también de igual tamaño, y caben en mi boca, que es un caño, todas las aguas que hubo en el diluvio.

El color de mi rostro es encarnado, no tengo barbas, ni tenerlas creo; soy de talle gigante y muy delgado.

Y siendo como soy un hombre feo, de mujeres bonitas hay atajos, que incansables me roen los zancajos.

Y también están Joaquín Lorenzo Luaces (1826-1867), Gertrudis Gómez de Avellaneda (1814-1873), Luisa Pérez de Zambrana (¿1835?1922) y sobre todo Juan Clemente Zenea (1832-1871), que al igual que Plácido muere fusilado, traductor y seguidor, de autores franceses, poeta, según Cintio Vitier, «de la intemperie solitaria", cuyos aportes "son múltiples, pero todos convergen en un solo sentido: la mayor hondura, irradiación y pureza de su cubanidad».

Ya en pleno siglo XX, aparecen las voces fuera de serie de José Manuel Poveda (1888-1926) y Regino E. Boti (18781958). El primero, deslumbrado por la perfección formal y cultivador de una conmovedora egolatría, arremete contra «la desastrosa moral de Cristo, la hipócrita y cobarde moral de los mediocres», $y$, según el severo juicio crítico de Vitier, «otras insensateces por el estilo». Entre las sensateces, sin embargo, está su cultivo del soneto, de notable factura, que figura entre las más logradas en toda la literatura cubana. Vaya aquí una muestra, el titulado «El trapo heroico»:

Contra el muro, aplastado en deplorable marco, casi mugriento, desteñido, así el signo preclaro que un glorioso momento del pretérito ilumina, semeja un buitre cínico y odioso que exhibe las carroñas de su ruina;

así el pendón, con gesto denigrante, pregona las heridas que ha sangrado, publica los dolores que ha sufrido;

así el pendón es ya lo vergonzante y lo trágico de un Crucificado, para escarnio del pueblo redimido.

Por su parte, Regino E. Boti, en el prólogo de su más difundido poemario, Arabescos mentales (1913), confiesa que ha preferido «una poesía ni gélida ni volcánica, justa en el equilibrio de lo anímico y material». A un crítico tan sagaz como Cintio Vitier le interesa en particular su segundo libro, El mar y la montaña (1921), "donde abundan los paisajes polícromos y sintéticos, con toque vanguardista y ardiente sensualidad de la pupila».

Sería una tarea interminable, y además superior a mis fuerzas y a mis lecturas y asimismo a los márgenes de esta charla, un análisis pormenorizado de la poesía cubana en este siglo que nos deja. La isla, con su cultura «antropófaga» que siempre se caracterizó por $\mathrm{cu}$ banizar lo que llegaba a sus costas y a sus cánones, en un comienzo por vía marítima, luego por vía aérea y ahora presumiblemente por internet, ha ido acumulando nombres $y$ obras que, al menos en poesía (y también en pintura) la sitúan entre los tres o cuatro países que han dado creaciones más notables al castigado continente mestizo.

Simplemente para aquilatar ese aporte, me limito a mencionar aquí, además de los ya citados, los nombres de Juan Marinello, Manuel Navarro Luna, Regino Pedroso, Dulce María Loynaz (Premio Cervantes 1992), Agustín Acosta, José Zacarías Tallet (a quien Fernández Retamar homenajeara en un poema memorable), Rubén Martínez Villena (heredero de Martí en su enardecimiento patriótico, que también, como al Apóstol, lo lleva a la muerte), Mariano Brull (el inventor de la jitanjáfora), Emilio Ballagas y su cultivo de las «sensaciones», así como la entrañable matancera Carilda Oliver Larra (1924) y los más cercanos Samuel Feijoo, Cintio Vitier, Fina García Marruz, Pablo Armando Fernández, Roberto Fernández Retamar, Fayad Jamís (con un pa- 
sado surrealista al que no dio totalmente la espalda, quizá sea en el fondo un romántico, que atravesó la pobreza, la soledad, el hambre, distintas nieves y distintos trópicos), Luis Suardíaz, Luis Rogelio Nogueras (1945-1985) fallecido en plena madurez creativa, Miguel Barnet, Raúl Hernández Novás, Reina María Rodríguez, Ángel Escobar, y otros autores, también estimables, que por distintas razones prefirieron el exilio, como Eugenio Florit, José Ángel Buesa, Justo Rodríguez Santos, Gastón Baquero, Heberto Padilla, Belkis Cuza Malé.

Por todo ello, y sin que este gesto signifique de ningún modo un propósito meramente selectivo ni menos aún excluyente, me he permitido elegir de ese vasto y prestigioso nomenclátor a sólo cuatro nombres, cuyas obras, por distintos matices y circunstancias, han despertado en mí, como simple lector, un interés particular. Son cuatro: José Lezama Lima, Eliseo Diego, Roberto Fernández Retamar y Nancy Morejón.

Si alguna vez pudo tener vigencia latinoamericana el hallazgo de Rilke, que definía la fama como «una suma de malentendidos», debe haber sido en relación con José Lezama Lima, nacido en La Habana en 1910 y muerto en esa misma ciudad el 9 de agosto de 1976. Figura descollante del grupo Orígenes (en el que asimismo participaron Cintio Vitier, Fina García Marruz, Eliseo Diego, Octavio Smith, Ángel Gaztelu, Cleva Solís, José Rodríguez Feo, Virgilio Piñera), no sólo su gravitante poesía sino también su papel de animador cultural adquieren relevancia a partir de 1937, año en que aparece Muerte de Narciso, su primer título. Max Henríquez Ureña sostendría años más tarde que si ese libro inicial fue «una revelación», el segundo, Enemigo rumor (1941), «fue una revolución». La obra de Lezama se va completando posteriormente con Aventuras sigilosas (1945), La fijeza (1949), Dador (1960), en poesía; Analecta del reloj (1953), La expresión americana (1957), Tratados en La Habana (1958), La cantidad hechizada (1970), ensayos; y sus novelas Paradiso (1966) y Oppiano Licario (1977). El conjunto siempre ha sido altamente estimado, a nivel latinoamericano, por una elite intelectual que a menudo se envanece de su propia admiración, como si el mero hecho de entender a Lezama les otorgara una patente de talento y erudición. Primer malentendido: si bien Lezama es un poeta difícil, sólo en raras ocasiones resulta impenetrable, hermético.

Confieso que a veces he sentido que se levantaba un muro entre su poesía y mi atención de lector, pero ese muro no era precisamente el hermetismo, sino cierta extraña sensación de que la poesía era en este autor una empresa estrictamente privada, un enfrentamiento entre esa mirada fija o retador desconocido que, según Lezama, es la poesía, y el poeta que acepta su reto y la resiste. Quizá por eso en su poesía no hay puentes hacia el lector y cuando los hay son tan frágiles que teme emprender su travesía. Ahora bien, el hecho de que rara vez me haya atrevido a cruzar esos puentes, no ha impedido que, desde mi orilla, distinga lo esencial de sus aventuras sigilosas y admire a plenitud la extraña coherencia y la delirante libertad con que este poeta insólito se manejó en su mundo. Quizá haya en la poesía latinoamericana de este siglo sólo otros dos escritores pertenecientes a la misma familia de solitarios libérrimos: los argentinos Macedonio Fernández y Juan L. Ortiz.

Por supuesto que en la obra de Lezama se podrían rastrear diversas influencias europeas (Proust y T.S. Eliot entre las más notorias). No obstante, si se dice que Lezama es esencialmente cubano, se expresa la verdad (el propio Lezama lo dice de sí mismo) pero también en esa verdad hay un malentendido, ya que la cubanidad de Lezama no le viene de la realidad tal cual es, sino de lo que Vitier llama «su experiencia vital de la cultura». No importa que en algunos poemas (verbigracia: «Venturas criollas», «El coche musical», «Oda a Julián del Casal») surja una terminología palmariamente cubana; Lezama rara vez toma la fauna, el paisaje, o los simples objetos, en su estado natural, sino que «cada color tiene su boca de agua» $y$ «el agua enjuta se trueca en la lombriz», o sea que el mundo se le da en imágenes, que es un modo de decir que se le da en cultura. Lo cubano en Lezama pasa por la cultura.

Cortázar, que fue un agudo estudioso de este poeta, ha anotado que Lezama «no se siente culpable de ninguna tradición directa. Las asume todas...; él es un cubano con un mero puñado de cultura propia a la espalda, y
JOSE LEZAMA LIMA

ENEMIGO RUMOR

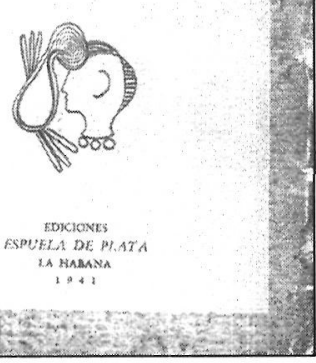

Poesía cubana del siglo XX: un vistazo personal y selectivo

MARIO BENEDETTI 


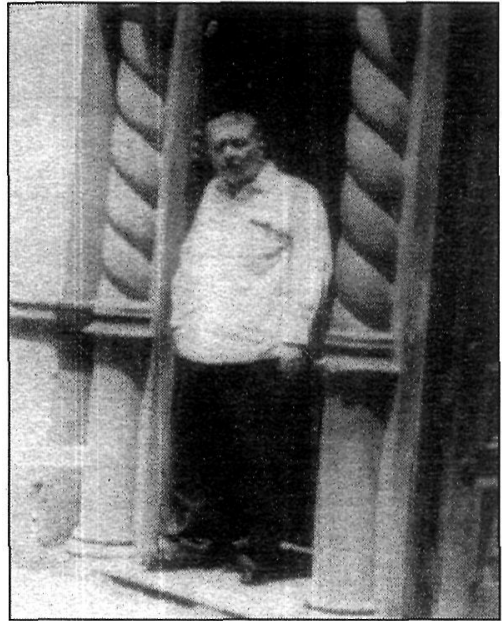

José Lezama Lima. el resto es conocimiento puro y libre, no responsabilidad de carrera». Vitier ha dicho de Lezama: «Es el único entre nosotros que puede organizar el discurso como una cacería medieval». Ahora bien, en una cacería medieval, ¿a quién le importaba el animal cazado? Lo espléndido era el espectáculo, el alarde de la cacería. En una conferencia de Lezama, ¿a quién le importaba el tema? Lo espléndido era asistir a la organización de sus metáforas, de sus series verbales, de sus palabras-imágenes. La primera vez que lo escuché, hace exactamente treinta años, estuve hipnotizado durante una hora: iba de estupor en estupor frente al chisporroteo imaginero de aquel voluminoso y disneico orador. Pero al finalizar la conferencia no habría podido decir honradamente cuál había sido el tema. Recordaba fulgores, estallidos, efectos, inéditos acoplamientos de palabras, pero imposible reconstruir en qué campo temático se inscribían. Tengo la impresión de que su estilo brillante y barroco, si bien puede generar cierta fatiga en una novela o en un ensayo, tensa magistralmente el arco para la flecha poética.

Cuanto más libre logra ser Lezama en su poesía, mejor tensión adquieren sus imágenes. La imagen es su clave decisiva, pero también su forma suasoria. Por lo pronto, Lezama se dicta a sí mismo su retórica, y no se esclaviza a ninguna ajena. Lo cierto es que en sus poemas las palabras adquieren una nueva vigencia, que no es exactamente la tradicional pero tampoco es totalmente otra. A veces su originalidad está en las vecindades que inaugura, aun en sus títulos: "Doble desliz, sediento», «Pífanos, epifanía, cabritos», «Peso del sabor»; otras veces está en las inéditas profundidades a que somete una palabra más o menos gastada, como ocurre en el «Llamado del deseoso».

Tampoco se esclaviza a un dogma. Y aquí viene otro malentendido. Lezama fue confesadamente católico. Pero ¿̇donde reside su religiosidad? Difícil hallarla a simple vista en un pagano tan vocacional. Hay que rastrear minuciosamente sus textos para encontrar un atisbo de dogma. No obstante está la religión, con su costado pagano, claro. Está en las estructuras poéticas, que a veces son catedrali- cias, y otras sólo parroquiales; está (lo dice él mismo) en la «religiosidad de un cuerpo que se restituye y se abandona a su misterio; en cierta liturgia de los oficios terrestres; en la eternidad como concepto del no-tiempo». Por eso su obra jamás podrá ser confundida con la poesía pura, y tiene razón Retamar cuando afirma que en Lezama «el reconocimiento de la poesía como aventura verbal lleva al poeta trascendentalista frente al verbo y su misterio, no sonoro... sino místico».

La religiosidad está, paradójicamente, en su enfoque de lo erótico. Cuarto malentendido: el célebre capítulo VIII de Paradiso le ha dado una fama poco menos que pornográfica. $\mathrm{Y}$ aunque si se toman las meras líneas descriptivas de ese capítulo, pueden extraerse todas las conjeturas imaginables e inimaginables, lo cierto es que su transcurso está invadido por palabras como verbo, encarnación, fervor, espiritu, etcétera, de clara inspiración litúrgica. De todas maneras, el escándalo y la polémica provocados por ese capítulo, incluyen una exageración, con implicancias extraliterarias que, en algún aspecto, entroncan, con el quinto y - por ahora-último malentendido: el específicamente político, que formó parte de una campaña (a la que el poeta estuvo por supuesto ajeno) destinada a imponer la imagen de un Lezama perseguido por la Revolución. Tanto su confeso catolicismo como su libertad para encarar lo erótico en todas sus variantes, fueron datos ávidamente recogidos por los órganos de penetración cultural norteamericana, así como por ciertos intelectuales, cubanos y no cubanos, residentes en Estados Unidos y en Europa, con el propósito de provocar una ruptura entre el escritor y la Revolución. Sin embargo, para su desencanto, la primera edición de Paradiso (con su quemante capítulo VIII sin cortes) fue publicada en Cuba y en cambio algunas de sus posibles reediciones han encontrado problemas frente a la censura de otros países. Por otra parte, a partir de 1959 se publicaron en Cuba numerosos y fundamentales libros de Lezama: $D a$ dor (1960), Antología de la poesía cubana (1965), Órbita de Lezama Lima (1966), La cantidad hechizada (1970) y Poesias completas (1970). En ese mismo año, la Casa de las Américas publicó una recopilación de textos sobre Lezama Lima. Luego han aparecido numerosas reimpresiones de sus obras, como La expresión americana y Confluencias. un vistazo personal y selectiv MARIO BENEDETTI 
Había escrito en Enemigo rumor: "Una oscura pradera me convida». Hay muchas praderas oscuras y posibles, pero ahora el poeta ha aceptado el convite de la más oscura. No olvidemos que en 1968 había expresado: «Heidegger sostiene que el hombre es un ser para la muerte; todo poeta, sin embargo, crea la resurrección, entona ante la muerte un hurra victorioso». A esta altura, tras haber entonado (¿quién lo duda?) su hurra victorioso, este Gran Solitario, este poeta insólito, este artífice de su resurrección, estará por fin instalado en su oscura pradera, más allá de todo malentendido.

Cuando Eliseo Diego (nacido en La Habana en 1920 y fallecido en México en 1996) publicó su «Responso por Rubén Darío» y colocó como epígrafe los célebres versos: «Buey que vi en mi niñez / echando vaho un día», se me aclaró de pronto la hasta ese momento para mí misteriosa relación entre el poeta nicaragüense y caudal, con todos los Olimpos a sus órdenes, y este cubano, silencioso y observante, rumiador de metáforas, reinventor del pretérito, que trataba a las palabras con un respeto, y a las cosas con una devoción, poco menos que inencontrables en la actual poesía latinoamericana. Eliseo no nacía del Darío total, sino más bien de aquellos dos versos decisivos que desde hacía varios decenios parecían estar esperando su adecuada viñeta de Boloña.

Lo cierto es que la mejor poesía de este ser singular, que se enfrenta a la naturaleza y al prójimo en el sobrentendido de que una y otro son componentes del dios que él admite, instaura y descifra, tiene siempre alguna relación con las imágenes de infancia, con las nostalgias de una inocencia que, como el buey de Dario, todavía echa su vaho desvaneciente y evocador sobre el presente demasiado nítido, demasiado rotundo. $Y$ esto sin perjuicio de que otros vahos también afluyan. "A medida que me vuelvo más real», escribió Eliseo, «el soplo del pánico me purifica».

Una lectura pausada e indagadora de toda la obra poética publicada por este autor, permite confirmar que su presencia en las letras cubanas ha sido el hilo conductor que serenamente la atraviesa, regulándola, trayéndola a cauce. En la calzada de Jesús del Monte (1949) es un libro fundamental, ejemplar en más de un sentido, y es inapreciable su irradiación a las promociones que le siguieron.
Nostalgia es la primera palabra que acude cuando uno se enfrenta a la poesía de Eliseo; tan evidente es la voluntad de rescate que allí se concentra. Es curioso comprobar que, a diferencia de lo que ocurre con otros rememoradores, las evocaciones de este poeta se conjugan en general en tiempo presente. El evocador no desarraiga a los seres y las cosas de un pasado que a veces se vuelve trampa y se vuelve retórica; más bien prefiere trasladarse, casi diría en persona, a contemplarlos, a sentirlos, a tributarlos.

Quizá el poema en que más clara

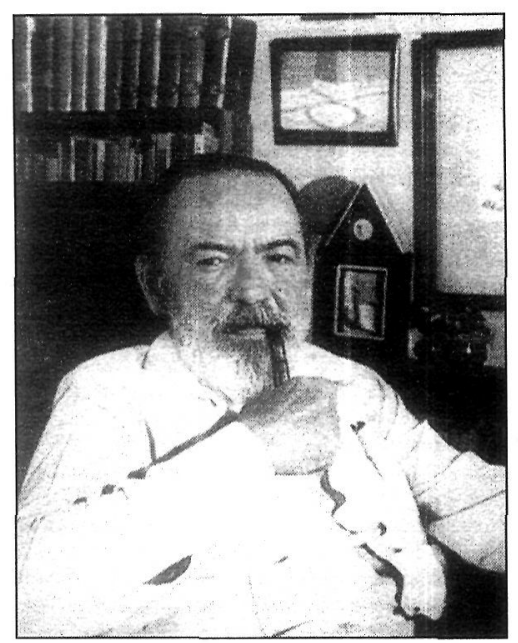

Eliseo Diego. aparece esa actitud, sea «El sitio en que tan bien se está», despabilado reposo en que el autor se instala a disputar serenamente al tiempo su destino. Antes que recrear las imágenes del pasado, prefiere reconstruir su mirada de entonces, y más aún: los sueños que la respaldaron. «Aquí no pasa nada, no es más que la vida / pasando de la noche a los espejos». En ciertas ocasiones crea a tal punto para ese pasado una presencia actual, que hasta se anima a trasladar allí al lector, y no sólo al lector, también a sus cinco sentidos: "Oigamos las figuras, el son tranquilo de las formas, / las casas transparentes donde las tardes breves suenan». Es obvio que el poeta no consigue derrotar al tiempo, pero sí vender cara su derrota. Con sus sucesivas treguas, con sus inventados respiros, con sus buenos pretextos, va demorando al tiempo, le va pidiendo implícitamente que no transcurra; en fin, lo va combatiendo con sus mismas armas, con su propio estilo de erosión.

En la dedicatoria de su segundo libro, Por los extraños pueblos (1958), definió la poesía como «el acto de atender en toda su pureza». $\mathrm{Y}$ eso es en definitiva lo que ha hecho Eliseo: atender, y para sentirse atento entre las palabras y bajo los astros, en la sala o entre la lluvia, en el patio o en la cabaña, ha podido y sabido recuperar su inocencia, que aquí no es ingenuidad ni bobería sino una limpia astucia para entender el mundo.

En el siguiente libro, El oscuro esplendor (1966), que incluye algunas de las muestras más certeras y depuradas de su poesía, hay una significativamente titulada «Avisos», que testimonia el nuevo grado de esa inocencia sabia, de ese coraje inmerso en tanta alarma: «el

Poesía cubana del siglo XX: un vistazo personal y selectivo MARIO BENEDET"TI 


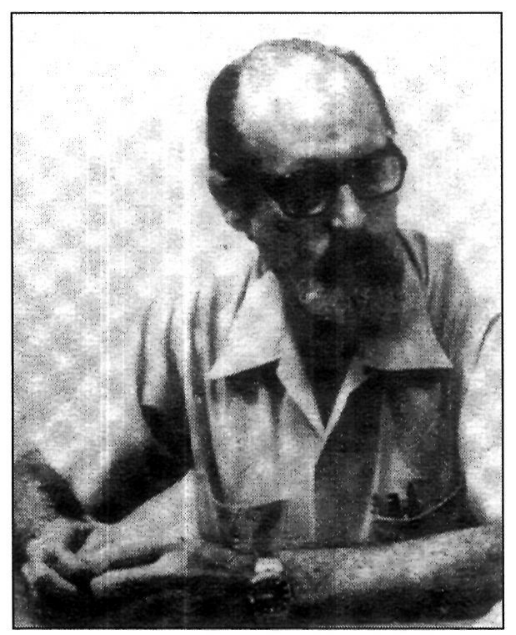

Roberto Fernández Retamar. joven ama el ruido de la muerte / pero el viejo teme su olor». Llegado a esta actitud, sin prisa pero con causa, Eliseo rehace su calma, contabiliza «los rápidos abismos de la noche», mira sin estupor su propia soledad y la ajena, así como la regular pero siempre mensurable distancia que las separa. Este sincero cristiano no tiene inconveniente en expulsar de su alma, de su vida, de su templo, al falso candor y otros mercaderes. Su nostalgia se ha transformado en lección, en dura lección aprendida.

Con su balance ya efectuado y sus grises conclusiones extraídas, Eliseo estuvo listo para una saludable distensión y ésta ocurre en un libro fuera de serie, Muestrario del mundo o libro de las maravillas de Boloña (1968). Allí halló finalmente su Olimpo, pero qué poco se parece al de Darío. Allí los mitos, las leyendas, son meras ilustraciones, un simple muestrario de letras y viñetas, extraído del catálogo de José Severino Boloña, un peculiar impresor que proponía a su clientela deliciosas láminas, capaces de aludir a todos los temas y subtemas del universo y sus alrededores. Todo allí comparece: desde un ejemplar tan inesperado como la curvilínea imagen del Tiempo, en alada y majestuosa reclinación, que Steinberg podría firmar sin el menor bochorno, hasta la ingrávida efigie del equilibrista, seguida además por innumerables galeras, herramientas, gatos, tambores, paraguas, casas, ruecas, peces, signos zodiacales, firmamentos. A partir de esos impagables grabados, frecuentemente a medio camino entre la heráldica y la instantánea, a partir de esa iconografía que alguna vez fue cotidiana y hoy resulta quimérica, Eliseo imagina, convive, trasueña, vislumbra. Como nunca antes en su poesía, Eliseo opta por el humor: la figura es tan sólo el impulso, la provocación, el inicio de un tranquilo delirio en el que el poeta se sumerge sonriendo, como si se tratase de un pretexto alucinógeno.

Para mi gusto, los más notables aciertos de este libro fuera de serie, ocurren cuando el poder de invención no se pone fronteras demasiado rígidas; cuando, por ejemplo, crea una explicación de portento para el equilibrista: «No es como nosotros el equilibrista, / sino

que más bien su naturalidad comienza donde termina la naturalidad del aire; allí es donde su imaginación inaugura los festejos / del otro espacio en que se vive de milagro / y cada movimiento está lleno de sentido y belleza».

El libro es un juego, claro, pero no es sólo eso. $\mathrm{Al}$ asomarse por un instante a esos paisajes candorosos, a esos seres inmóviles, a esas calmas en pena, el poeta lleva consigo todas sus inquietudes y fruiciones. De ahí que lo más maravilloso de estas «maravillas de Boloña» sea precisamente lo que no está en el cuadro, lo que el reconstructor ve más allá de la imagen propuesta. $\mathrm{Y}$ entonces el muestrario del mundo se convierte en lo que en definitiva es todo buen libro de poemas: un memorial de individuo, al que a su vez puede asomarse el prójimo-lector con todas sus inquietudes y fruiciones.

Roberto Fernández Retamar (nacido en La Habana, en 1930) es una de las personalidades más dinámicas e irradiantes de la actual cultura cubana. Profesor, traductor, poeta, crítico, ensayista, durante un largo período estuvo al frente del Centro de Estudios Martianos. Actualmente preside la Casa de las Américas y desde 1965 dirige la prestigiosa revista que publica esa institución.

Retamar es uno de esos hombres de transición que se levantan (así lo dice en uno de sus poemas más logrados) «entre una clase a la que no pertenecimos, porque no podíamos ir a sus colegios ni llegamos a creer en sus dioses» $\mathrm{y}$ "otra clase en la cual pedimos un lugar, pero no tenemos del todo sus memorias ni tenemos del todo las mismas humillaciones»; «entre creer un montón de cosas, de la tierra, el cielo y el infierno, / y no creer absolutamente nada, ni siquiera que el incrédulo exista de veras».

Buena parte del indudable atractivo de su poesía tiene que ver con la franqueza, a la vez humilde y orgullosa, a la vez convicta y desconcertada, con que el poeta asume, en nombre de una insegura promoción, de una clase alarmada, su inconfortable función transitiva, su condición de inestable, casi improvisado, puente entre dos épocas pugnantes, contrapuestas.

Aunque en la obra de Retamar sólo hay, según creo recordar, dos poemas que llevan el título «Arte poética», en realidad son varias las artes poéticas distribuidas a lo largo y a lo ancho de su itinerario creador. En algunas de esas aproximaciones a la razón de su trabajo,
Poesía cubana del siglo XX: un vistazo personal y selectivo MARIO BENEDETTI 
Retamar ironiza a expensas de sí mismo. Por ejemplo, en «Explicación»:

Siempre quise escribir un poema

Tan breve

Como aquel de Machado:

"Hoy es siempre todavía»;

O incluso como aquel de Ungaretti:

«M'illumino

d'inmenso";

Pero ya ven:

Me pierdo en explicaciones.

La humanización de las cosas y de la naturaleza, es, en esta poesía, una forma casi militante de asumir la realidad, ese «Vivo río de todo», que preocupa, conmueve, mortifica y complace a Retamar. Aun en los casos de más recóndita indagación, la realidad está presente como el diapasón que da el tono para el acorde subjetivo, interior. El autor adquiere su rigurosa vigencia cuando se vuelca en los demás.

En los libros anteriores a 1959, la poesía de Retamar trasmite una desalentada necesidad de fe; hasta el advenimiento de la Revolución y su aliento removedor, el amor es el único sucedáneo. El poeta se lanza al amor con todas sus nociones del mundo, con toda su expectativa vital, con todo su equipaje de palabras.

Entonces llega la Revolución, y el acontecimiento sacude, entre otras cosas, la vida familiar y hasta la vida interior de cada cubano. Son palabras (ahora en prosa) del propio Retamar: «Una revolución no es un paseo por un jardín; es un cataclismo, con desgarramientos hasta el fondo. Pero es sobre todo la deslumbrante posibilidad de cambiar la vida». El poeta siente, como todos, la tremenda conmoción, y fecha, en $1^{\circ}$ de enero de 1959 , un breve poema, «El otro», que es uno de los frutos literarios más nobles de ese repentino acceso a un destino nacional:

Nosotros, los sobrevivientes, ¿A quién debemos la sobrevida? ¿Quién se murió por mí en la ergástula? Quién recibió la bala mía,

La para mí, en su corazón?

¿Sobre qué muerto estoy yo vivo,

Sus huesos quedando en los míos,

Los ojos que le arrancaron, viendo

Por la mirada de mi cara,

Y la mano que no es su mano,
Que no es ya tampoco la mía,

Escribiendo palabras rotas

Donde él no está, en la sobrevida?

Lo mejor de la producción de Fernández Retamar, no sólo desde un punto de vista comunicativo sino sobre todo desde un punto de vista artístico, es posterior a 1959. Cualquier antología de la poesía latinoamericana se enorgullecería de albergar poemas como «Felices los normales", «Oyendo un disco de Benny Moré», "Le preguntaron por los persas» y por supuesto, "In memorian Ezequiel Martínez Estrada», «Usted tenía razón, Tallet: somos hombres de transición» y dedicado a su padre muerto. La revolución no siempre está presente con todas sus letras; sí está presente en la conciencia del doble privilegio que le toca vivir al poeta: ser efectivamente un hombre de transición y verlo con los ojos bien abiertos.

Pasemos ahora a Nancy Morejón. Nacida en La Habana, 1944, licenciada en Lengua y Literatura Francesas, traducida a varios idiomas y traductora de poetas franceses y francoantillanos, autora de dos libros fundamentales sobre la obra de Nicolás Guillén, con los que obtuvo en 1980 el Premio Nacional de Ensayo «Enrique José Varona» y el Premio Nacional de la Crítica. El más conocido de sus varios libros de poesía, Richard trajo su flauta y otros argumentos, fue premiado en 1967 por un jurado integrado por Lezama Lima, Nicolás Guillén, José Agustín Goytisolo, Yannis Ritzos, Roque Dalton, Oscar Oliva, Jaime Augusto Shelley y Regino Pedroso. Con Piedra pulida (1988) y con Elogio y paisaje (1997) obtuvo el Premio de la Crítica.

Desde su primer libro, Mutismos (1962), que Nancy publica a sus 18 años, la asunción de lo real es algo más que un gesto. Ahí inicia tempranamente su búsqueda de identidad, pero empieza negándose a sí misma: «No hay esperanza. No hay dolor. / Soy sin mí». Dos años después aparece Amor, ciudad atribuida. Gerardo Fulleda León considera que el rasgo primordial de este libro es «el mirar con intensidad para apropiarse de cada recoveco de lo cotidiano [...]. La realidad irrumpe sin recurrir a descripciones ni a una enumeración
Poesía cubana del siglo XX: un vistazo personal y selectivo MARIO BENEDETTI 


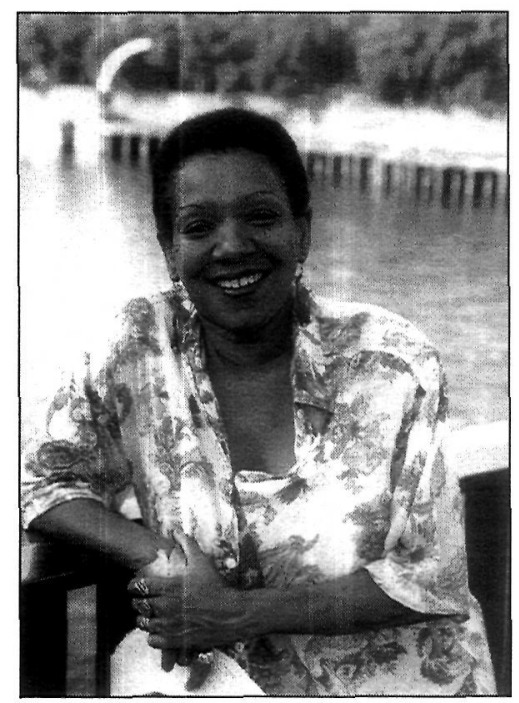

Nancy Morejón que desgaste el objeto: la ciudad, sus moradores y el amor, sino que por medio de una selección de los elementos sensibles y peculiares que lo conforman, aquellos que lo dotan de una efectiva trascendencia, nos va a entregar una visión muy específica, surcada de ironía y paradoja».

Amor y ciudad, que serán una constante en la poesía de Nancy, son sus dos descubrimientos, sus revelaciones. La ciudad no es sólo envase sino especialmente contenido. $Y$ es el contenido el que cobra vida en esos poemas, por medio de metáforas inéditas, de gestos afectivos: «Los carpinteros trabajan con los cabellos enredados, / llenos de fuego y entre sus ojos hay, de nuevo, / otra vez, la ciudad que apacigua los árboles». En la ciudad atribuida de Nancy, no sólo los carpinteros sino también los árboles son habitantes.

Hay también en esta obra un amplio destaque del tema amoroso, que incorpora un significado, cálido y muy preciso, de una solidaridad afectiva. El amor es asimismo la derrota de la soledad, y si el ser amado es destinatario del poema amoroso, es también porque se trata del próximo prójimo, del testigo emotivamente implicado en un paisaje, una situación, un riesgo.

Richard trajo su flauta y otros argumentos es un libro fundamental en esa trayectoria. A primera vista parece un alarde de espontaneidad y, sin embargo, por debajo de esa naturalidad, crece (y madura) un dominio del lenguaje, que no sólo es verbal. Hay un dialecto de las situaciones que va transformando cada poema en una metáfora ambiental.

Octubre imprescindible (1983) y Piedra pulida (1986) son obras de una conmovedora tensión poética. La primera incluye el poema «Mujer negra», uno de sus textos más conocidos, y sobre el cual ha confesado la autora: «Lo escribí tratando de reconstruir a través de un yo poético - no es Nancy Morejón- la historia de una parte del pueblo cubano, las mujeres de este país».

Piedra pulida es una culminación. El tú del amor es de nuevo un testigo. $Y$ hay dos poemas, «A un muchacho» $\mathrm{y}$ «La buenaventura», que por sí solos justificarían el libro. Y existe otro rasgo vital que, curiosamente, ha sido detectado por una norteamericana, Alice Wal- ker: «Qué refrescante y casi insólito el hecho de leer los poemas de una mujer negra que está en paz con su país».

De todas maneras, hay en Piedra pulida una tensión dramática mucho más intensa que en libros anteriores. No sólo en poemas tan logrados como «Negro» o «Amo a mi amo», sino especialmente en «Elegía de las conversaciones», un poema convocado por la muerte de un carpintero, que en sus versos finales dice así:
Oh carpintero de los barrios.
Rosa regresa con sus panes,
Rosa regresa con sus peces, con su sonrisa de coral...
Hay un rincón para tu arroz, para tu carne.
Eras de un pueblo chico y amabas la ilusión.
La madera cantaba entre tus manos.
Esas vetas tan cálidas
que brotan de tu mesa
mecieron los recuerdos
en tu lengua dormida.
Así te podrán ver
los que hoy te lloran.
Allá va tu pañuelo
y tras él van tus hijos.
Oh carpintero del adiós verdadero:
viven como no viven
los que mueren sin causa;
vives en tu fiel muerte diaria.
Oh mi amigo que hablabas
como el tenue murmullo del madero.

Por otra parte, la muerte y la vida aparecen inevitablemente ligadas en diversas instancias de este libro, por ejemplo en el poema titulado «Mundos», cuyos estremecidos y estremecedores versos finales nos informan:

Mi casa es un gran barco

Y trazo con mis venas el mapamundi nunca visto

de los islotes a mi diestra.

Vivo en mi casa que es un barco

(qué poderoso barco me cobija)

Vivo en mi casa que es un barco

(qué poderosa espuma me refresca)

Vivo en mi barco vivo

amparada del trueno y la centella

Mi casa es un gran barco

digo

sobre la isla dorada

en que voy a morir
Poesía cubana del siglo $\mathrm{XX}$ : MARIO BENEDETTI 
Por último, el reciente volumen publicado por Nancy, Elogio y paisaje, reúne dos anteriores: Elogio de la danza (México, 1982) y Paisaje célebre (Venezuela, 1993). En el primero, se da una extraña conjunción entre las bailarinas que danzan como peces o pájaros, y los pájaros con vuelos como danzas. En el segundo, la naturaleza y el arte cruzan y entrecruzan sus presencias y ausencias. Naturalezas muertas que resucitan y que pueden ser una «telaraña de siemprevivas / alzándose hacia el cielo hasta formar un arco iris» o «la verde verbena [que] florece en los canteros, / no necesita ninguna química especial» o «una golondrina que creó el más lento de los veranos».
Aunque después de Nancy Morejón han aparecido varios poetas jóvenes y muy jóvenes, algunos de ellos realmente talentosos, que comparecen enganchados a nuevas propuestas $\mathrm{y}$ antiguas negaciones, creo que es mejor culminar este vistazo personal y selectivo con la poesía de Nancy Morejón, que es desde ya una eclosión vital y tiene suficiente hechizo como para inundar de sensible perplejidad y bienvenido afecto a sus fieles seguidores. Tal vez se deba a esa natural inserción en la historia, en la geografía, y en el hermoso color de su piel, que la poesía de Nancy Morejón, junto con el espectáculo de sus metáforas, incite al lector a mantener un diálogo nutricio con su intimidad generosa y expuesta. 

atención especial a la literatura cubana y sus relaciones con los procesos políticos y culturales del siglo $X X$. Ha dedicado varios artículos y libros a la obra de José Martí y, sobre todo, de José Lezama Lima y el Grupo Orígenes. Actualmente orienta su investigación hacia la literatura colonial $y$, en concreto, a la obra del Inca Garcilaso de la Vega.

\title{
DE LA REVOLUCIÓN VANGUARDISTA AL ESTALLIDO DE LA REVOLUCIÓN. NOTAS SOBRE POESÍA Y POLÍTICA ENTRE 1930 Y 1959
}

\author{
REMEDIOS MATAIX
}

\section{1}

José Antonio Portuondo, Bosquejo histórico de las letras cubanas, La Habana, Ministerio de Educación, 1960, pág. 57.

\section{2}

Citado por Cintio Vitier en Ese sol del mundo moral. Para una historia de la eficidad cubana, México, Siglo XXI, 1975, pág. 128.

3

Cintio Vitier, op. cit., pág. 139.

De la revolución vanguardista al estallido de la Revolución. Notas sobre poesía y política entre 1930 y 1959

REMEDIOS MATAIX
Como explicó José Antonio Portuondo en su Bosquejo bistórico de las letras cubanas, la revista de avance (1927-1930), abanderada en Cuba del arte «nuevo» y los movimientos de Vanguardia, al enmudecer voluntariamente como punto final de su trayectoria, quiso acabar con un período de la literatura cubana durante el cual «los escritores creyeron hallar la solución de los problemas fundamentales del país mediante el esfuerzo minoritario de las porciones cultas, con ignorancia de las grandes mayorías nacionales»: la lucha contra los procedimientos cada vez más cruentos de la dictadura de Gerardo Machado habría empujado a esos escritores «hacia el convencimiento de la impotencia de los intelectuales, y al descubrimiento de las masas, cuya «revelación» intelectual les hiciera, entre otros sofismas, don José Ortega y Gasset»1.

Los dirigentes más radicales de aquella generación pronto publicarían un llamamiento a las armas titulado "Tiene la palabra el camarada máuser», donde Raúl Roa condensaba en ese verso de Vladimir Maiakovski los nuevos principios revolucionarios:

Estamos viviendo no sólo el resquebrajamiento objetivo del régimen colonial. Estamos en presencia, también de una revuelta de masas contra el imperialismo yanqui y su verdugo Machado (...) Por eso ya sobran la palabra y la pluma. La conciencia popular está madura para el vuelo redentor. Ahora se hace urgente predicar a balazos. La consigna es única y definitiva: ¡tiene la palabra el camarada máuser! ${ }^{2}$
La «revuelta de masas» contra Machado prosiguió hasta 1933, cuando Rubén Martínez Villena organiza la huelga general que provoca la caída y la fuga del dictador el doce de agosto. Pero el país no quedó en manos revolucionarias: las maniobras norteamericanas para prolongar los días de gobierno afín siguieron tejiendo sus redes en torno al presidente provisional Carlos Manuel de Céspedes, y lo harían con cada uno de su sucesores (Mendieta, Barnet, Gómez y Laredo) gracias a Fulgencio Batista. Hombre de confianza de Washington, Batista gobernó en la sombra desde 1934 como jefe del ejército, y después lo hizo como presidente constitucional (19401944), aunque distó mucho de llevar a la práctica las apreciables conquistas políticas y sociales de la Constitución de 1940. «La farsa republicana adquiría la invisibilidad de un simulacro perfecto - apunta Cintio Vitier- La ficción se apoderaba, no sólo del ideal republicano como sucedió hasta Machado, sino también del ideal revolucionario» ${ }^{3}$, pues los gobiernos del Partido Revolucionario Cubano ("Auténtico») de Grau San Martín (19441948) y Prío Socarrás (1948-1952) tampoco fueron mucho mejores. Eduardo Chibás, líder de la alternativa más honesta, el «Ortodoxo» Partido del Pueblo Cubano - cuyo emblema electoral era una escoba, para barrer a los corruptos-, se suicidó públicamente en 1951 después de un mitin radiofónico. El desprestigio de los «Auténticos» y la debilidad de los «Ortodoxos» sin Chibás, convencieron a Batista de la viabilidad de un golpe militar, que 
llevó a cabo el diez de marzo de 1952. Eran tiempos de desilusión y fatalismo:

Después de haber llevado a las ciudades la lucha que nuestras guerras de independencia desarrollaron en los campos, la revolución del 30 se quedó clamando muda en la conciencia del pueblo como un gesto ensangrentado y trunco ${ }^{4}$.

Cuba vivía y padecía la frustración ya casi endémica de esa República Moral que animó el proyecto liberal nacionalista del siglo XIX, con la aguda nostalgia que sugería Eliseo Diego en un poema de los años cuarenta:
Tendrá que ver
cómo mi padre lo decía:
la República...
Como si fuese una materia,
el alma, la camisa,
las dos manos,
una parte cualquiera de su vida.
Yo, que no sé
decirlo: la República ${ }^{5}$

Pero la aventura cultural de Orígenes, la revista que fundó José Lezama Lima en 1944 y el amplio grupo de escritores que se reunió a su alrededor desde $1934^{6}$ y acabó adoptando el nombre de esa publicación, compensaba el pesimismo histórico posmachadista con su optimismo trascendente, eje central de una especie de revolución pacífica donde la palabra y la pluma volvían a desempeñar un papel fundamental:

Creíamos que cada forma alcanzada artísticamente tenía que lograr, por una nobleza más evidente, una claridad para el estado, entonces indeciso, fluctuante, mediocrísimo (...) Queríamos un arte, no a la altura de la nación, indecisa, claudicante y amorfa, sino de un estado posible, constituido en meta, en valores de finalidad?

Algo parecido a aquel Estado ideal concebido como meta común debía ser para ellos la España republicana que representaban las ilustres figuras que habían pasado por $\mathrm{La} \mathrm{Ha-}$ bana aquellos años y sufrían las consecuencias de la dictadura de Franco. Sobre todo, María Zambrano, cuyo magisterio sobre Orígenes tuvo mucho de apuesta intelectual por un futuro mejor, por algo que pudiera revocar de una vez «esa ley fatal de nuestra historia» que formulaba el pensamiento origenista: «El callejón sin salida en que siempre había desembocado el esfuerzo heroico: la ley del imposible» ${ }^{8}$. La filosofía que animó al grupo, pues, se erige como un ejemplo perfecto de asimilación en sentido contrario de aquellas premisas de que hablaba Portuondo: Orígenes no sólo nunca padeció la «impotencia de los intelectuales», sino que su convencimiento en el poder regenerador de las minorías cultas y su valoración de la cultura como resistencia - según el término que le sería emblemáticoadquieren proporciones míticas. Lo explicaba Lezama con palabras apasionadas en una polémica pública con Jorge Mañach, representante de aquel vanguardismo ya extinguido, que reprochaba a Orígenes, entre otras cosas, no reconocer su deuda con la generación anterior, y que había sido de los primeros en propugnar una superación de lo que él mismo llamó La crisis de la alta cultura en Cuba (1925). Por eso le respondió Lezama, convertido en portavoz del grupo:

De la lucha contra la espantosa realidad de las circunstancias surgió en la sangre de todos nosotros la idea obsesionante de que podíamos, al avanzar en el misterio de nuestras expresiones poéticas, trazar, dentro de las desventuras rodeantes, un nuevo y viejo diálogo entre el hombre que penetra y la tierra que se hace transparente?

Pero quizá por esa oposición con la generación de avance, que no dudó en entregarse a la militancia más activa, durante mucho tiempo se aceptó sin cuestionarla una caracterización de los poetas de Orígenes como grupo apolítico, voluntariamente aislado en su «taller renacentista» y ajeno a los acontecimientos que sacudían su país durante unas décadas convulsas y decisivas para su historia. La verdad es que los origenistas, con Lezama a la cabeza, siguen conservando aún buena parte de esa imagen que creo no les corresponde, al menos en tan alto grado: el significado de Orígenes no puede entenderse del todo si no vemos su aventura como algo mucho
4 Ibídem, pág. 134.

5

Eliseo Diego, «El sitio en que tan bien se está», En la calzada de Jesús del Monte, La Habana, Úcar, 1949

6

Entre los más activos, Eliseo Diego, Virgilio Piñera, Cintio Vitier, Fina García Marruz, Gastón Baquero, Lorenzo García Vega, Ángel Gaztelu, Octavio Smith y José Rodríguez Feo.

7

Lezama, «Recuerdos» (1957), en Revista de la Biblioteca nacional José Martí, núm. 2 (1988), pág. 26.

8

Véase Cintio Vitier, La luz del imposible (1957), La Habana, Úcar, 1957, pág. 15.

9

Lezama, «Respuesta y nuevas interrogaciones. Carta abierta a Jorge Mañach» (1949), recogida en Imagen y posibilidad, ed. de Ciro Bianchi, La Habana, Letras Cubanas, 1981, pág. 187.

De la revolución vanguardista al estallido de la Revolución. Notas sobre poesía y política entre 1930 y 1959

REMEDIOS MATAIX 
En «Señales. La otra desintegración», Orígenes n 21 (1949), pág. 60 .

11

Lezama, "José Marií o la crepitación del sarmiento» (1950), recogido en La Habana. Un poeta interprefa su ciudad, ed. de José Prats Sariol, Madrid, Verbum, 1991, pág. 178.

12

En su Consagración de La Habana. Peculiaridades del Grupo Orígenes en el proceso cultural cubano, Miami, Letras de Oro, 1991.

13

Roberto Fernández Retamar, "Generaciones van generaciones vienen...», La Gaceta de Cuba, no 13 (1962), pág. 5.

14

Ibídem.

De la revolución vanguardista al estallido de la Revolución.

Notas sobre poesía y política entre 1930 y 1959

REMEDIOS MATAIX menos autista de lo que suele pensarse. Por una parte, porque, si bien es verdad que sus componentes más conocidos se entregaron a la elaboración de una obra difícil y cada vez más densa, con ello pretendían compensar la oquedad ambiental, ese «raimiento" del que se hablaba constantemente en la revista. Renunciaron a cualquier activismo que no fuera el poético, pero sustentaron con su obra una actitud cultural que tuvo una gran conciencia histórica, una honda inquietud social e incluso - aunque desdibujada por la complejidad de su formulación - una actitud políticamente comprometida: aquella sentencia de Lezama que acabó siendo divisa del grupo, «Un país frustrado en lo esencial político puede alcanzar virtudes y expresiones por otros cotos de mayor realeza» ${ }^{10}$, no condujo nunca a una fuga de la realidad; se llevó a la práctica como un modo de compensar sus carencias y como una labor sumergida de oposición que abanderaba en sus publicaciones la figura de Martí como «cerrado impedimento a la intrascendencia y la banalidad» ${ }^{11}$, a la espera de ese gran momento que según ellos traería su «resurrección» como operante fuerza histórica.

$Y$ por otra parte, porque esa peculiar aventura política de Orígenes se entiende mejor si se tiene en cuenta que la revista de Lezama no fue un fenómeno de época único y sin diálogo con otros grupos y publicaciones de su momento. En rigor, ni la Orígenes de los años cuarenta y cincuenta, ni su disidente -y replicante-Ciclón (1956-1959) como tampoco, obviamente, las cinco revistas anteriores del grupo (Verbum, Espuela de Plata, Nadie parecía, Clavileño y Poeta) fueron órganos de una generación en sentido estricto, como a veces parece haberse entendido. Es preciso recordar que la llamada Tercera Generación de la República (la generación posvanguardista) incluye a otros muchos escritores cubanos que no se identificaron ni colaboraron con sus coetáneos de Orígenes y que, por tanto, usar el término 'generación' para referirse a lo que, en rigor, fue un grupo (por las razones que ha estudiado detalladamente Jesús Barquet) ${ }^{12}$, confunde más de lo que ayuda.

En aquella generación, además de los origenistas y sus colaboradores más jóvenes (Pablo Armando Fernández, Fayad Jamís, Edmundo Desnoes o Roberto Fernández Retamar), se incluyen escritores como José Antonio Portuondo, Ángel Augier, Mirta Agui- rre, Onelio Jorge Cardoso, Carlos Felipe, Alcides Iznaga, Aldo Menéndez o Samuel Feijoo, que casi nada o nada en absoluto tuvieron que ver con las convicciones de Orígenes acerca de la militancia sólo poética: «Vivieron con la mirada puesta en las realidades de su país —explicó Roberto Fernández Retamar-: Algunos llegaron a la franca militancia en un partido revolucionario, como Mirta Aguirre; otros, procediendo más por la libre, se acercaron a los campesinos humildes en vida y obra (Cardoso) e incluso lucharon durante años por reivindicaciones campesinas (Feijoo); y no faltó entre ellos quien tomara las armas en la loma, como Aldo Menéndez. Su obra literaria es un testimonio de esa preocupación, de esa actitud $»^{13}$.

La diferencia fundamental entre esas dos facciones estuvo, sin embargo, no tanto en el compromiso con la realidad sociopolítica del país, sino en cómo se expresó ese compromiso, vital y literariamente, por parte de una y otra tendencia; $y$, sobre todo, en cómo se entendió esa expresión por parte de la generación inmediatamente posterior, protagonista del proceso revolucionario desencadenado a partir de 1959. Resumiendo mucho la cuestión, puede decirse que, mientras lo que se consideró entonces el legado fundamental de Orígenes se redujo a la insistencia del grupo en la seriedad y la constancia con que debía enfrentarse la labor cultural, al margen (o a pesar de) la indiferencia oficial y los vaivenes nocivos de la actualidad - una actitud que se consideró entonces, en el mejor de los casos, escapista y amante de la torre de marfil-, los autores no origenistas ofrecían una mucho más nítida militancia política, continuadora del modelo ideológico revolucionario de los primeros años de la República, que generó la llamada Protesta de los Trece (1923), el Grupo Minorista, la revista de avance y, en suma, la llamada Generación del 23, algo que convertía a esos autores, a los ojos de los más jóvenes, en «herederos directos del aliento de la extraviada Revolución del 33»14.

Continuar o romper con el modelo de aquella mítica Generación del 23 eran a fines de los años 30 las dos opciones disponibles para los autores que, como Lezama y su grupo, empezaban entonces su trayectoria intelectual. Y sin duda Orígenes heredó también su aliento utópico, pero prefirió trasladar las coordenadas a un espacio más afín con la sen- 
sibilidad de sus componentes: la creación cultural. Para ellos aquella militancia revolucionaria se entendió como una «parálisis» que interrumpía las enormes posibilidades que atribuían a la creación, pues vieron las virtudes iniciales de la generación vanguardista empañadas por cierta deformación causada por la «secreta vinculación con los vicios de la época», según Cintio Vitier, quien en sus famosas conferencias de 1957 sobre Lo cubano en la poesía — como «la Biblia del Origenismo» se las llegó a conocer después-15 explicaba los pormenores literarias de esa recepción:

...Intentaron superar la ausencia de finalidad en que se hundían el país y las letras, atacando enemigos de cartón como eran la cursilería, el academicismo y la oratoria engolada, y proponiéndose la meta abstracta del avance por el avance, de lo nuevo por lo nuevo. Pero ¿a dónde se iba? Después del primer impacto, su movimiento era más ilusorio que real. Ninguno de los grandes esfuerzos creadores de la época, poco o nada conocidos entonces en Cuba (la obra de Proust, de Joyce, de Eliot, de Claudel) halló eco decisivo en sus páginas, que se mantuvieron siempre sobre la más visible y fugaz espuma de «lo nuevo», cifrado en la hueca palabra «vanguardismo» ${ }^{16}$.

Para Orígenes, pues, la capacidad inspiradora de aquel grupo se había extinguido: «tiene ya sabor y aroma de época», añade Vitier, y en su obra «todo tiene poco fondo, una intrascendencia y una lisura peculiar» ${ }^{17}$. También Lezama, algunos años antes, en su carta abierta a Jorge Mañach, había afirmado sentenciosamente que aquella generación «cumplió y se cumplió». Según él, esos autores habían traicionado la entrega a su obra, al relegarla a un segundo plano atraídos por la «inmediatez» de lo que llama «la ganga mundana de la política positiva» (por oposición a la política «esencial» $)^{18}$. Y a la parálisis se unía el descrédito de la conducta individual de algunos de sus miembros, Jorge Mañach entre ellos ${ }^{19}$. Pero esa apreciación generalizada a toda la promoción del 23 constituía, más que una verdad constatable, una cuestión de valoración personal: para los no origenistas, no sólo no existió esa parálisis creativa, sino que vincularon su obra a una continuidad con la de algunas de las figuras más politizadas de la generación anterior (como Nicolás Guillén y Juan Marinello, muy en activo ambos entonces) y practicaron una explícita orientación anti-origenista desde la
Gaceta del Caribe, en nombre de la creación militante que, según ellos, «bebía sus jugos vitales en el bumus popular» ${ }^{20}$.

Como sugiere el análisis de Jesús Barquet, quizá la influencia de César Vallejo sea uno de los elementos más reveladores de las verdaderas diferencias que produjeron esa polarización de la generación posvanguardista en torno a la percepción de la generación literaria inmediatamente anterior: «La admiración por Vallejo, compartida por ambos sectores, revela las peculiaridades de cada uno. La obra del peruano los llevó [a los origenistas] a comprender la unidad indisoluble entre ética y creación», mientras que para los no origenistas, según el crítico, la influencia fundamental de Vallejo se tradujo en la adopción de «sus prosaísmos vigorosos, su inquietud, su esquemática sequedad (...) y el ansia por donde César Vallejo - el César Vallejo de España, aparta de mi este cáliz- edificaba hombres» ${ }^{21}$. Sea como sea, no hay duda de que ambos grupos compartieron el mismo desencanto del presente que ya intentara combatir el vanguardismo precedente de la revista de avance con aquella frustrada Revolución del 33, aunque no lo tradujeron con las mismas formas. Siendo fenómenos aparentemente contrapuestos, la circunstancia histórica común define posiciones que confluyen en muchos puntos (el pensamiento de José Martí como soporte ideológico, sin ir más lejos) y empujan, también al Grupo Orígenes, a emprender la puesta en práctica de algunos de los valores profundos que el breve vanguardismo cubano había esbozado sin llegar a desarrollarlos.

Esa Vanguardia, digamos "ortodoxa», la que se definía a sí misma como tal, tuvo tardía repercusión en el panorama cultural de la Isla y se identifica con la publicación que fue su portavoz desde 1927 hasta 1930: la revista de avance, aunque su verdadero nombre era el número cambiante del año, con lo que se subrayaba así, hasta en el título, su afán de renovación constante; su deseo de avanzar. La metáfora de un barco zarpando que daba pie al manifiesto "Al levar el ancla», firmado por Juan Marinello, Francisco Ichaso, Alejo Carpentier, Martín Casanovas y Jorge Mañach, condensaba los objetivos radicalmente aventureros del grupo:

Lo que no lleva en su bagaje [este nuevo bajel] es la bandera blanca de las capitulaciones. Lo inmediato en
15

La fórmula es de Lorenzo García Vega, en Los años de Orígenes, Caracas, Monte Ávila, 1979, pág. 69.

16

Cintio Vitier, Lo cubano en la poesía (1957), La Habana, Instituto Cubano del Libro, 1970, pág. 370 .

17

Ibídem, pág. 372.

18

Lezama, «Respuesta y nuevas interrogaciones. Carta abierta a Jorge Mañach», cit., pág. 189.

19

Hasta su segundo y definitivo exilio en 1960, la trayectoria ideológica de Jorge Mañach, duramente atacada por sus compañeros de generación, dibujó ese curioso vaivén «al apego de la política positiva» que los origenistas no tardarían en reprocharle también: fue uno de los fundadores del $A B C$ lantiguo grupo terrorista contra la dictadura de Machado que pasó a ser Partido Reformista), Secretario de Instrucción Pública durante el gobierno de Mendieta (1934), luego Delegado en la Asamblea Constituyente de 1940 por el Partido del Pueblo Cubano, y finalmente (1944) Ministro de Estado en los últimos meses del gobierno de Fulgencio Batista, quien para entonces ya había orientado hacia objetivos nada democráticos aquella «astucia instintiva» que alguna vez le reconoció Mañach.

20

Véase Ricardo Luis Hernández Otero, "Orígenes y las revistas cubanas contemporáneas a ella», en W.AA, Vigencia de Orígenes, La Habana, Academia, 1996, pág. 77.

21

Jesús Barquet, op. cit., págs. 3941.

De la revolución vanguardista al estallido de la Revolución. Notas sobre poesía y política entre 1930 y 1959

REMEDIOS MATAIX 


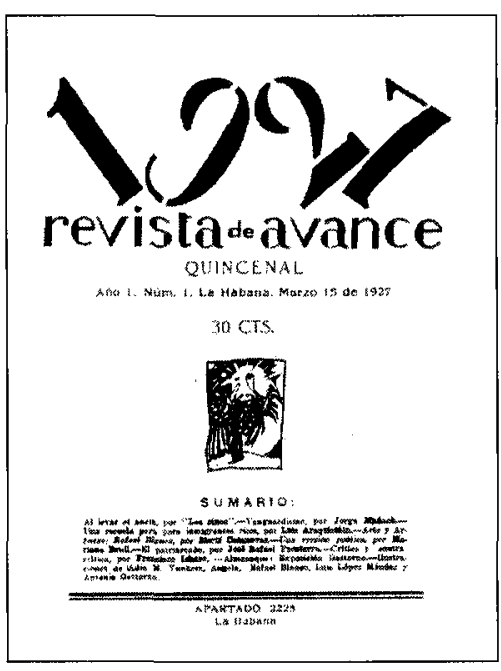

Portada del primer número de revista de avance.

nuestra conciencia es un apetito de novedad, de movimiento. Por ahora sólo nos tienta la diáfana pureza que se goza mar afuera, lejos de la playa sucia, mil veces hollada, donde se secan, ante la mirada del mar, los barcos inservibles o que ya hicieron su jornada (...) Salimos, pues, rigurosamente a la aventura, a contemplar estrellas, a ver si por azar nos topamos con algún islote que no tenga aire provinciano, donde uno se pueda erguir en toda su estatura ${ }^{22}$.

En sus cuatro años de viaje, avance cumplió el papel histórico que le correspondía: intentar renovar ese «ambiente provinciano», difundir los movimientos de vanguardia e

22

"Al levar el ancla», 1927 revista de avance, $n^{\circ} 1$ (1927), pág. 1. Puede verse en la edición facsímil de la revista a cargo de Martín Casanovas, La Habana, Instituto Cubano del Libro, 1972.

23

Carlos Ripoll, La Generación del 23 en Cuba, New York, Las Américas, 1968, pág. 36.

24

José Antonio Portuondo, op. cit., pág. 58.

De la revolución vanguardista al estallido de la Revolución. Notas sobre poesía y política entre 1930 y 1959

REMEDIOS MATAIX introducir el mayor número de tendencias, corrientes y figuras del «arte nuevo» (y con él, las primeras manifestaciones de poesía "pura» y «social»). Pero, sobre todo, la revista fue esencial para canalizar la revitalización política en Cuba que se había acentuado desde principios de los años veinte. Recordemos, sólo como ejemplo, que en 1926 se publica el famoso poema «La zafra» de Agustín Acosta, donde el poeta se hace eco ya de esas preocupaciones de signo social y nacionalista, lamentando el desastre republicano con versos destinados a alcanzar resonancia emblemática: «Musa patria, esto no fue / lo que predicó Martì».

Inquietudes similares constituían la razón de ser del movimiento "de ideas" que se concretó alrededor del llamado Grupo Minorista, núcleo de la joven izquierda habanera que se había ido constituyendo desde 1923. Ese año tuvo lugar lo que se conoce como la Protesta de los Trece (trece «minoristas»), que, encabezados por el poeta Rubén Martínez Villena, concentraron el movimiento de oposición contra la corrupción y los turbios gobernantes de la llamada seudorrepública. Y cinco de esos trece - los firmantes del manifiesto «Al levar el ancla»- decidieron fundar en 1927 la revista de avance, quizá no con el propósito de dar voz pública al minorismo, pero así fue.

Tal vez la trayectoria individual de Martínez Villena, su enérgica reacción frente al estancamiento republicano a través de su entrega al activismo político más contundente, señalara la verdadera vocación del grupo renovador: la «generación del optimismo ciego», en palabras de Carlos Ripoll ${ }^{23}$, se abría paso histórico armada con las ansias renovadoras del vanguardismo. Eso explicaría la rápida orientación del grupo vanguardista hacia la militancia política, cuando en 1930 se intensificó la lucha contra la dictadura de Gerardo Machado y sus conciencias creyeron encontrar una oportunidad de expresión en la organización de aquella Revolución que quiso estallar en 1933, pero fue duramente reprimida.

Ambas cosas, política y literatura, habían avanzado íntimamente unidas hasta entonces, y las consecuencias se habían revelado ya notablemente profundas para la segunda, que desembocaba en un panorama dual: la vanguardia, cuando no se socializó o se politizó, se depuró. Lo resumía también José Antonio Portuondo:

La lucha contra la dictadura impuso como quehacer la satisfacción de las necesidades populares como un aspecto de la lucha política. Los escritores «descubren» entonces al pueblo, a las masas, en sus porciones más explotadas: el negro, el campesino, el proletario. Por otra parte, la creciente preocupación social de la literatura, que acentúa su carácter ancilar, determina la evasión de un grupo de escritores que aspiran a eludir las urgencias políticas y salvarse a sí mismos en el seno de sus propios universos poéticos, de acuerdo con las fórmulas contemporáneas de la poesía pura ${ }^{24}$.

Así, la revista de avance, después de haber cumplido con su cometido estético, se extinguió quizá justo cuando debía hacerlo: en 1930 la intensificación de la lucha contra la dictadura de Machado tuvo como consecuencia el recrudecimiento de la represión. El gobierno amenazaba con instaurar la censura previa a la prensa y avance decidió autosilenciarse como modo de protesta y para no tener que someterse a esa otra «depuración», ya nada poética.

Del complejo de intenciones del breve vanguardismo cubano surge el contexto en el que ha de inscribirse la obra del Grupo Orígenes, que desafió con idéntica determinación (aunque con algo de estar de vuelta de batallas inútiles) las mismas frustraciones, las mismas inconsistencias y, en suma, la misma atmósfera disolvente de la república que la vanguardia quiso combatir. Pero el nuevo grupo se negaba a sentirse heredero de las dogmáticas exclusiones vanguardistas y emprende su propia 
aventura cultural, "ya no tan interesada en avanzar como en sumergirse en busca de los orígenes», como apuntó Cintio Vitier ${ }^{25}$. En el editorial que presentaba la revista se incluía una extensa declaración de principios a los que respondía el significado de un título que proponía fundir tradición y modernidad, orígenes y originalidad:

No le interesa a Orígenes formular un programa, sino ir lanzando las flechas de su propia estela. Como no cambiamos con las estaciones, no tenemos que justificar en extensos alegatos una piel de camaleón. No nos interesan superficiales mutaciones, sino ir subrayando la toma de posesión del ser. Queremos situarnos cerca de aquellas fuerzas de creación, de todo fuerte nacimiento, donde hay que ir a buscar la pureza o impureza, la cualidad o descalificación de todo arte (...) Nos interesan fundamentalmente aquellos momentos de creación en los que el germen se convierte en criatura y lo desconocido va siendo poseído ${ }^{26}$.

Esos intereses se tradujeron pronto en un acercamiento novedoso a esa fecunda «tradición de la ruptura» de que hablara Octavio $\mathrm{Paz}^{27}$, desde que Lezama esgrimiera al frente del primer número de Espuela de Plata, la primera gran revista origenista (1939-1941), las «Razones» que señalaban para siempre la actitud de aquel grupo decidido a luchar sólo "contra el desgano inconcluso» ${ }^{28}$. La polémica directa quedaba descartada, a favor de esa actitud ajena a los debates sobre pureza e impureza, evasión y compromiso, que ya habían escindido la poesía española ${ }^{29}$ y empezaban a establecer dicotomías obligadas en la cubana: sólo había tiempo para la «artesanal alegría» de la creación y la necesidad de lograr con ella una resistencia silenciosa que, por otra parte, avanzaba las famosas tesis lezamianas sobre la creación "con rasguños proféticos» que expondrían también las páginas de Orígenes:

...Quizá la profecía aparezca entre nosotros como un candoroso empeño por romper la mecánica de la historia, el curso de su fatalidad. Suma de posibilidades para avizorar las tierras que tendremos que habitar como estilo de vida (...) No era una profecía de acentos directos, que solicitara de inmediato la calcinación de las piedras, por el contrario, consistía en esperar con estoica dignidad que el soplo, lo numinoso, fuera algún día, por la arribada de la poesía a la tradición, un castillo fuerte ${ }^{30}$.

Lo posible lezamiano se convertía así en categoría origenista fundamental, determinando la noción conexa de futuridad entendida como renacimiento continuado y reorientación de la historia; en suma, una utopía entendida, no como ensoñación evasiva, sino como una suerte de profecía social basada en el rescate, de entre las profundidades de lo cubano, de ciertas fuerzas impulsoras del progreso histórico. Lo posible así concebido como meta inspiraba la trayectoria origenista, orientando sus búsquedas hacia la revelación por la poesía de nuevas y mejores realidades. Y conviene recordar que presupuestos similares había expresado con insistencia el pensamiento de María Zambrano, cuyo magisterio, como es sabido, dejaría huellas indelebles en el espiritualismo de Orígenes, en sus lecturas de la tradición, en su interpretación de la historia y hasta en sus proyectos para dinamizar la sociedad. Había escrito la autora ya en 1939:

Se había llegado en la vida española a un extremo de desintegración, de aislamiento; precisamente al sentirse el individuo sin horizonte se sentía, no ligado, sino aislado. Es lo que sucede siempre que la relación entre lo íntimo, lo individual y lo social ha sido alterada. Resulta una mecanización de la vida social que encubre un absoluto desamparo del individuo que queda inerme (...) La nueva historia tendrá que ser un saber de reconciliación. Trataremos de encontrarla en su origen, en sus instantes fundamentales, tendremos que haber visto antes cuál es su íntima y verdadera constitución; cuáles son los sucesos fundamentales que la conforman. Esos sucesos, creemos, son aquellos que se trasparentan en sus formas más verídicas de expresión: pensamiento y poesía, tomando como género de la poesía, igualmente, la novela. En ese sentido, la interpretación de nuestra literatura es indispensable. Los sucesos de nuestra historia, lo que real y verdaderamente ha pasado entre nosotros en comunidad de destino aparece como en ninguna parte en la voz de la poesía. Poesía es revelación siempre, descubrimiento. Sucede que como nuestra más honda verdad se revela no es por la pura razón, sino por la razón poética ${ }^{31}$.
25

En el «Prólogo» a su Antología Cincuenta años de poesía cubana (1902-1952), La Habana, Dirección de Cultura, 1952, pág. 4.

26

Lezama, «Presentación», en Orígenes, $n^{\circ} 1$ (1944), pág. 5 .

27

En Los hijos del limo. Del romanticismo a la vanguardia (1974), Barcelona, Seix Barral, 1981, pág. 15.

28

Cfr. Lezama, "Razón que sea», Espuela de Plata, A (1939), pág. 2.

29

Me refiero, claro, a la polémica entre el modelo estético de Juan Ramón Jiménez y la "poesía sin pureza» que Pablo Neruda proponía en 1935 desde el manifiesto de Caballo Verde para la Poesía, convirtiéndose en portavoz de un sentimiento en auge.

30

Lezama, «Después de lo raro, la extrañeza», Orígenes, $n^{\circ} 6$ (1945), págs. 51-55.

31

María Zambrano, Pensamiento y poesía en la vida española, edición digital de la Biblioteca Virtual Miguel de Cervantes, 2000, sobre la primera edición de La Casa de España, México, 1939.

De la revolución vanguardista al estallido de la Revolución. Notas sobre poesía y política entre 1930 y 1959

REMEDIOS MATAIX 


\section{2}

Cintio Vitier, Lo cubano en la poesía, cit., pág. 485.

33

Lezama, «Alrededores de una antología», Origenes $n^{\circ} 31$ (1952), págs. 63-64.

\section{4}

Ibídem, pág. 64 .

35

En La familia de Orígenes, La Habana, Letras Cubanas, 1997. pág. 59.

36

En « $X$ y $X X »$, Orígenes, $n^{\circ} 5$ (1945), pág. 25.

37

Lezama, «Señales. La otra desintegración», Orígenes, $\mathrm{n}^{\circ} 21$ (1949) pág. 60.

\section{8}

Lezama, «Mariano» (1943), en Revista de la Biblioteca Nacional José Martí, núm. cit., pág. 12.
De la revolución vanguardista al estallido de la Revolución. Notas sobre poesía y política entre 1930 y 1959

REMEDIOS MATAIX
No cabe duda de que fue a la luz de esos mismos planteamientos (casi uno por uno) como enfocó Cintio Vitier sus decisivas «Consideraciones finales» que definían lo cubano origenista «bajo especie de fundación» y las búsquedas del grupo como antídoto contra esa otra desintegración que se producía también en la Cuba republicana:

Lo que en [otros] poetas era ingenuo, preconcebido o agresivo intento de "cubanizar» la poesía (...), es en nosotros necesidad profunda de conocer nuestra alma, cuando parece que sus mejores esencias se prostituyen o evaporan (...) Quizás, junto a la hermosa tradición de nuestro pensamiento eticista, la poesía signifique la única continuidad profunda que hemos tenido. A los pocos años de inaugurada la República, de la inspiración política de los fundadores coronada en la obra y la acción de Martí, apenas quedaba un grotesco fantasma. Hoy ya ni eso. Tenemos la sensación del estupor ontológico, de la situación vital en el vacío. Por eso volvemos los ojos al testimonio poéti$\mathrm{co}$, donde ese mismo vacío puede adquirir sentido como sintoma del ser y del destino (...) Es preciso situar lo cubano bajo especie de fundación $n^{32}$.

Por eso la polémica gran antología origenista Cincuenta años de poesía cubana (19021952) había subrayado ya la voluntad del grupo por fundar el "proceso creador de la nación», a través del «invisible metagrama histórico» conformado por "la mejor corriente de poesía que estructura la imaginación como historia, la imaginación encarnando en otra clase de actos y de hechos» ${ }^{33}$.

En ese proceso, y de acuerdo con sus presupuestos iniciales, Orígenes evitó siempre pronunciar cualquier filiación o rechazo programáticos. Y no podemos hablar tampoco de una «poética origenista» explícita que todos compartieran: el grupo se definió a sí mismo como «un estado de concurrencia, pero nunca un modo grupal de operaciones y coincidencia de criterios» ${ }^{34}$, y constituye un fenómeno polifónico que quizá sólo se pueda explicar, como ha hecho Fina García Marruz, «a partir de ese versus uni martiano: unidad de fines, diversidad de modos»35. De hecho, es suficiente recordar a autores tan diferentes entre sí como Eliseo Diego, poeta intimista de lenguaje sobrio, y Virgilio Piñera —una especie de anti-Orígenes, pese a ser parte irrenunciable del grupo-, cuya obra existencialista, insolente e irónica pareció siempre obsesiona- da por lo insustancial y lo absurdo de la existencia, precisamente lo que la de Lezama quiso afanosamente trascender.

Sin embargo, el grupo ha pasado a la historia como grupo, compartió sus aventuras estéticas y editoriales con clara conciencia de grupo y es reconocible como tal, de modo que algo los unió; según ellos, era una «secreta imantación», tal vez una actitud: la completa entrega al ejercicio creativo y al ambicioso proyecto que Lezama hacía brotar de él y que fortalecía la fe en la cultura, en su poder contra el pragmatismo vigente y en su capacidad de influencia social. "Yo sigo fiel a la manera clásica, es decir, un hallazgo, una creación, y después convertirlo en una religión, un alimento que pueda ser de todos», advirtiós ${ }^{36}$. Y esa «religión» resultó decisiva para la cohesión del grupo, pues daba forma a unas inquietudes comunes pero desdibujadas acerca de la utilidad de la literatura y la responsabilidad social del escritor.

En una de las «Señales» sobre la realidad sociopolítica del país que publicaba la revista, se apuntaba en 1949:

Medio siglo es unidad de tiempo apreciable para cualquier conclusión. Lo que fue para nosotros integración y espiral ascensional en el siglo XIX, se trueca en desintegración en el XX. ¿Por qué? Las conspiraciones bolivarianas, las guerras del 68 y del 95, Martí, la propaganda autonomista eran proyecciones que no han tenido par en el medio siglo siguiente (...) Aun los jouisser más optimistas tendrán que reconocer que las fuerzas de desintegración han sido muy superiores a las que en un estado marchan formando su contrapunto y la adecuación de sus respuestas (...) Esa corriente, honda en lo negativo, indetenible casi, hubiera podido ser contrastada si en otros sectores del gusto y de la sensibilidad se hubiera proyectado un deseo de crear, de mantener una actitud de búsqueda de lo capital y secreto ${ }^{37}$.

Si en la política republicana Lezama no encontraba estadistas dignos de ese nombre y de su cargo, tampoco había encontrado a esos artistas capaces de orientarlos en la dirección adecuada:

Que no hemos tenido estadistas agudos en la interpretación de los instantes o de los fenómenos de la polis, bueno: tampoco hemos tenido artistas capaces de comunicarle al hombre de estado una misión, o de enviarlos [sic] a una tierra descubierta por su extrañeza ${ }^{38}$. 
Por eso quiso asumir él ese papel: «explotar la decisión del arte para crear las posibilidades de un estado mucho antes que la visión tosca de los estadistas ${ }^{39}$, con la instauración, frente al estado real, de lo que llegó a llamar «una pequeña república de las letras» ${ }^{40}$.

De acuerdo con la labor «silenciosa» de Orígenes, Lezama no expuso nunca ese proyecto a través de un programa o una formulación acabada, y su coherencia se va revelando sólo a medida que enlazamos piezas en apariencia inconexas. Pero poco a poco la postura política del grupo fue cobrando nitidez y sus «Señales» se hicieron más valientes, protestando por la fuga de talentos, acusando a los representantes oficiales de la cultura de ser «contumaces letargíricos», o denunciando la «falta de imaginación estatal» y la «marcha hacia la desintegración» que los sucesivos gobiernos no hacían sino acelerar ${ }^{41}$. Algunas incluso deslizaron claves ya inconfundibles, a propósito del célebre anatema - desintegración-que la revista lanzaba contra la seudorrepública:

Ha existido siempre entre nosotros una médula muy por encima de esa desintegración. Existe entre nosotros otra suerte de política, otra suerte de regir la ciudad de una manera profunda y secreta. Han sido nuestros artistas, que procuran definir, comunicar sangre, diseñar movimientos. Mientras, la otra política, la fría, la desintegrada, ha rondado con su indiferencia y su dedo soez esa labor secreta que asombra ver en pie dando pruebas incesantes de su vocación como quien se dirige a su destino con misional misterio (..) Y ese grupo de nuestros artistas, si no ha vencido, está afanoso de mostrar quien venza ${ }^{42}$.

Había, por tanto, dos formas de hacer política: la inculta, falsa y desintegradora de los gobernantes oficiales, y la otra, una política secreta, profunda, auténtica, defensora de los valores de lo cubano y cultivada por los artistas, que ejercen en la amable República Lezamiana un misterioso poder redentor. Ese atractivo planteamiento hubo de ser un elemento decisivo para la cohesión del grupo, pues daba cauce a una ideología que no había encontrado acomodo en ninguna de las corrientes políticas cubanas de aquellos años, ni se reconocía con la capacidad (o el interés) para crear una nueva. La propuesta, además, daba solvencia histórica a una aventura que buscaba oscuramente en lo poético, en las esencias y en la vuelta a los orígenes una conquista del futuro. Recordemos que los poetas de Orígenes querían hacer «tradición», pero también profecía, «suma de posibilidades para avizorar las tierras que tendremos que habitar como estilo de vida» ${ }^{43}$. Y entendemos que esa poética profética -más que una (u otra) objetivación de Utopía en territorio americano-fue la fórmula lezamiana para un arte comprometido con su circunstancia, si enlazamos ese texto con lo que diría después en su emblemático ensayo Las imágenes posibles: «Ninguna aventura, ningún deseo por el que hombre ha intentado vencer una resistencia ha dejado de partir de una imagen ${ }^{44}$, y con lo dicho en el editorial del último número de Nadie parecía, inmediatamente anterior al primero de Orígenes, que llevó el significativo título de «Resistencia»:

No caigamos en lo del paraíso recobrado, que venimos de una resistencia, que los hombres que venían apretujados en un barco que caminaba dentro de una resistencia pudieron ver un ramo de fuego que caía en el mar porque sentían la historia de muchos en una sola visión. Son las épocas de salvación, y su signo es una fogosa resistencia ${ }^{45}$.

La obsesión por esa salvación cultural de Cuba se remonta, como es sabido, por lo menos hasta principios del siglo XIX, cuando los principales letrados del movimiento nacionalista (Félix Varela, José de la Luz y Caballero, Domingo del Monte) inventan la tradición de 'la cubanidad' y propagan la idea de una literatura nacional que «brota» naturalmente de ella. Desde entonces ese concepto cultural ha estado determinado por fines políticos, explícitos $\mathrm{u}$ ocultos ${ }^{46}$, y creo que esa misma determinación es innegable en el proyecto origenista. Su defensa de lo cubano ha podido entenderse como la de una noción de identidad absoluta, inmutable e impermeable al contexto - a ello contribuye el uso constante de términos como 'esencia', 'raíz', 'resistencia', incluso 'orígenes'-, pero en realidad es-' tá determinada por unas circunstancias históricas muy concretas.

$\mathrm{Al}$ evaluar la importancia de aquella «Biblia del Origenismo» que fue Lo cubano en la poesía de Cintio Vitier en el proceso de afirmación nacionalista cubano, Arcadio Díaz Quiñones concluyó que cumplía una función crucial, pues no sólo era el recuento de las di-
40

Cfr. "Carta abierta a Jorge Mañach», cit., pág. 188.

41

Cfr. Lezama, "Señales. Emigración artística», en Orígenes $\mathrm{n}^{\circ}$ 15 (1947), y «Señales. Alrededores de una antología», en el no 31 (1952).

42

En «Señales. Emigración artística», cit., pág. 45

43

Cfr. «Después de lo raro, la extrañeza», cit., pág. 52.

44

En Origenes, $n^{\circ} 17$ (1948), pág. 3.

45 Lezama, "Resistencia», Nadie parecía, n 10 (1944), pág. 1.

\section{6}

Véase Irma Llorens, Nacionalismo y literatura. Constitución e insfitucionalización de la «República de las letras cubanas», Lleida, Asociación Española de Estudios Literarios Hispanoamericanos, 1998.
De la revolución vanguardista al estallido de la Revolución. Notas sobre poesía y política entre 1930 y 1959

REMEDIOS MATAIX. 
47

Arcadio Díaz Quiñones, Cintio Vitier: la memoria integradora, San Juan de Puerto Rico, Sin Nombre, 1987, págs. 28 y $50-$ 51.

48

Lo cubano en la poesía, cit., pág. 18.

49

Gastón Baquero, «Tendencias de nuestra literatura», en Anuario culfural de Cuba 1943, La Habana, Úcar, 1944, pág. 264.

50

Cintio Vitier, Ese sol del mundo moral, cit., pág. 139.

51

«La más sutilmente corruptora influencia que haya sufrido jamás el mundo occidental (...), porque lo propio del american way of $\mathrm{li}_{\text {- }}$ fe es desustanciar desde la raíz los valores y esencias de todo lo que toca», se decía en Lo cubano en la poesía led.cit., pág. 494).

52

En Lo cubano en la poesía, cit., págs. 487 y 493.

53

Recordemos los motivos de Ariel (1900), según Rodó: «La reivindicación del abolengo histórico latino, como energía necesaria para salvar y mantener la personalidad de estos pueblos, frente a la expansión triunfal de otros (...), cuando la preeminencia del modelo anglosajón y la necesidad de inspirar la propia vida en la contemplación de ese arquetipo era el criterio que predominaba entre los hombres de pensamiento y de gobierno en las naciones de la América Latina.» Cfr. «El nuevo Ariel» (1914), en Obras completas, ed. de Emir Rodríguez Monegal, Madrid, Aguilar, 1967, pág. 1197.

De la revolución vanguardista al estallido de la Revolución. Notas sobre poesía y política entre 1930 y 1959

REMEDIOS MATAIX versas formulaciones del problema llevadas a cabo por sucesivas promociones de escritores (lo que «impone una trama a la historia literaria y a la historia de la cubanidad»), sino además convertía la literatura en «un instrumento de exaltación nacionalista»:

Esos textos críticos e históricos de Vitier pueden interpretarse como un ambicioso intento de fundamentar, preservar y sistematizar la continuidad cultural nacional, a la vez que se funda un discurso acerca de la literatura en el que la conciencia de la berencia marca su pensamiento, creando las condiciones que autorizan su propio discurso ${ }^{47}$.

El propio Vitier había insistido en el carácter histórico de los propósitos de su libro, explicando en el prólogo que entendía esa noción de lo cubano como el resultado de un complejo proceso de toma de conciencia de «lo que más genuinamente nos expresa en cada instante»:

No hay una esencia inmóvil y preestablecida, nombrada lo cubano que podamos definir con independencia de sus manifestaciones sucesivas y generalmente problemáticas, para después decir: aquí está, aquí no está. Nuestra aventura consiste en ir al descubrimiento de algo que sospechamos, pero cuya identidad desconocemos. Algo, además, que no tiene una entidad fija, sino que ha sufrido un desarrollo y que es inseparable de sus diversas manifestaciones históricas ${ }^{48}$.

En otras palabras: la identidad no puede verse como expresión de una realidad previamente constituida, al margen de los discursos que la articulan, de ahí que podamos concluir que también en la visión origenista de lo cubano bajo especie de fundación, esa fundación estuviera puesta al servicio de un proyecto cultural (y político) específico. Creo que con esa reformulación, en la que la definición de la nación se entiende de acuerdo con la imagen que ofrece de ella la escritura, el proyecto origenista se orientaba hacia la legitimación del papel fundamental de los representantes de la cultura en la construcción de un nuevo Estado. Con él se obedecía al perfil del «buen letrado» que exigió para Nuestra América Martí: «estrategia es política»; «la solución está en crear».

El enorme poder regenerador que el proyecto de Lezama y su grupo atribuye a los re- presentantes «selectos» de la cultura (ellos mismos) como idóneos dirigentes del país, puede ser interpretado como el equivalente en lo simbólico del compromiso político que otros autores expresaron explícitamente, o ejercieron entonces a través de la militancia real. «La nación consistía en una dilución de sus jugos, en un escaparse sus aromas mejores», explicó Gastón Baquero: «Se imponía concentrarla en espíritu, en forma, en expresión» ${ }^{49}$. Definir y defender la identidad de lo cubano fue para ellos la única forma fecunda de hacer política en un momento en que «el país estaba hueco. Sólo su alma, oculta, vivía» ${ }^{50}$.

La dilución amenazaba tanto desde la creciente influencia norteamericana ${ }^{51}$, como desde la complicidad de sucesivos gobiernos que parecían empeñados en imponerla. Y ese problema apuntaba hacia el peligro principal de la historia cubana: el de la absorción por el otro (errónea solución al atraso histórico contra la que ya se había opuesto su adorado Martí), y la norteamericanización resultante de esa teleología fatalista de la inevitable subordinación al más fuerte. España, aportaba, en cambio, un linaje idóneo para preservar la identidad de lo cubano: «la terca resistencia de lo español»y «el eticismo hispánico eterno» ${ }^{52}$. Las circunstancias no podían ser más acordes con la oportunidad de ese renovado arielis$m o^{53}$. Para ellos el contexto replanteaba, agravándola, la problemática del 98: el período semicolonial, oficialmente, había llegado a su fin con la derogación de la famosa Enmienda Platt en 1934 - por la que la Constitución cubana establecía el derecho de Estados Unidos a «intervenir para garantizar la independencia y ayudar a cualquier gobierno a proteger las vidas, la propiedad y la libertad individual»-, pero en la práctica la «república mediatizada» suponía una menos explícita pero igualmente poderosa situación neocolonial con pretensiones anexionistas, lo que se agudizó con la llegada al poder de Batista como dictador (1952-1958). El sentimiento independentista también se reavivó, y el proyecto origenista, en el fondo, recordaba las claves martianas para emprender la resistencia. Por eso afirmaba Vitier, parafraseando el curioso «Principio de la ley de gravitación de Cuba» de John Quincy Adams, que, si en lo económico y hasta en lo político, ese «fruto maduro de una rama lejana del árbol hispánico» había caído 
en manos del imperialismo norteamericano, «desde el ángulo espiritual nos escaparemos siempre», explica, «si somos capaces de entrar en contacto con las fuerzas positivas que laten detrás de nuestros vicios y flaquezas» ${ }^{54}$. Idénticos propósitos inspiraron las célebres conferencias de Lezama sobre La expresión americana, que coincidieron en 1957 con las de Vitier sobre Lo cubano en la poesía; dos grandes «actos» origenistas que, cada uno a su modo, intentaron contribuir «al rescate de nuestra dignidad $\gg^{55}$ confiando una vez más en el poder salvador —compensador, al menosde la cultura.

Desde este punto de vista, el proyecto de Orígenes puede entenderse sin dificultades como continuador de los que el pensamiento anticolonialista cubano del XIX intentó llevar a cabo, apuntalando las bases, demarcando los contornos y estableciendo los principios éticos y estéticos que debían regir ese «estado alternativo» que también se llamó la República de las Letras:

Durante las primeras décadas del siglo XIX, los letrados prominentes se proponen reestructurar el campo intelectual cubano creando un campo literario alternativo que ellos definen como un espacio autónomo que ha de permitirles alcanzar una mayor independencia intelectual y profesional. Desde ese espacio, designado metafóricamente como la «República de las Letras Cubanas», esos letrados aspiran a tener una influencia cultural y política decisiva en la sociedad ${ }^{56}$.

Lo que sugiero es que, en el pensamiento de Lezama - que por algo despreciaba los intentos disolventes de la Vanguardia- no hay solución de continuidad entre esas aventuras intelectuales y la suya propia, emprendida en un momento en que la historia de Cuba hacía particularmente oportuna la aplicación de ese legado para el establecimiento de la República de la Poesía esbozada en Orígenes. Y ahí se fundamenta buena parte de la famosa marginalidad que ha definido al grupo: al margen de modas y coyunturas estéticas, su pensamiento se identificó con el de aquéllos que habían asumido la causa de la cultura como una misión heroica, convencidos de que la labor del intelectual podía triunfar donde la política había fracasado. En ellos encontró Lezama una tradición donde enraizar su ambiciosa Teleología Insular, que insistió siempre en funda- mentar poéticamente tanto la vida como la política, en entender el compromiso desde la poesía, y en perseguir la creación de una $\mathrm{Cu}$ ba posible -es decir: irrealizada pero no irrealizable-, que pudiera materializar la confluencia (también poética y también martiana) entre la justicia, la belleza y la verdad.

La tan mencionada resistencia origenista se basaba en el fondo en la creación de algo similar a esa República de las letras anticolonial: un espacio alternativo y autónomo que aspiraba a hacer de la cultura una nueva religión en un mundo sin valores, que se opuso al poder vigente y sus excesos anticulturales, y que intentó combatir la desintegración y la docilidad ante la influencia norteamericana. Orígenes fue también una realización de esa ciudad letrada que estudió Ángel Rama y que «articula las relaciones de la cultura con el poder, consolidando el orden por su capacidad para expresarlo rigurosamente en el nivel cultural» ${ }^{57}$. Pero en este caso por oposición, mediante una ideologización destinada a derribar el orden vigente - la «farsa republicana» primero, la dictadura después-y a consolidar otro que ellos entendieron más auténtico. Eso hacía del grupo «más que una generación, un Estado de lo necesario posible en nuestra sensibilidad, una resistencia erguida frente al tiempo» ${ }^{58}$.

Pero el tiempo no pasaba en vano, y ya en los años cincuenta, precisamente cuando sus más famosos integrantes daban el paso a la madurez creativa, el grupo empezaba a no poder ser tenido como tal: la década final de Orígenes, $\tan$ agitada en lo político con el golpe de estado de Batista y el inicio de la lucha guerrillera en las montañas, fue agitada también por serios enfrentamientos internos que aceleraron el final quizá biológico de la revista ${ }^{59}$ y provocaron el «cisma» que hizo que del número 35 de Orígenes salieran a la venta dos versiones distintas, una dirigida por Lezama y la otra por José Rodríguez Feo, hasta entonces, codirector de la revista común.

Muy similares, pero no idénticas, la revista de Lezama conservó casi al completo - hubo casos de vacilación - la nómina de colaboradores durante ése y cinco números más, hasta el cierre de la publicación en 1956 por dificultades económicas. La de Rodríguez Feo tampoco se alejaba mucho del espíritu de la Orígenes común, pero pronto se convertiría en la enérgica Ciclón (1955-1957 y 1959) diri-
54

Lo cubano en la poesía, cit., págs. 493-494.

55

Cfr. Lezama, «Sumas críticas del americano», en La expresión americana (1957), La Habana, Letras Cubanas, 1993, pág. 110.

56

Irma Llorens, op. cit., pág. 20.

57

Ángel Rama, La ciudad letrada, Montevideo, Arca, 1984, pág. 41.

58

Lezama, "Lozano y Mariano», Orígenes, nº 23 (1949), pág. 45.

59

La causa fue la publicación en el número 34 de 1953 del texto "Crítica paralela» de Juan Ramón Jiménez, donde el poeta, ya desde su retiro, lanzaba los últimos dardos contra los autores de la Generación del 27 que alguna vez reconoció como discípulos. Al parecer, Lezama publicó el texto de Juan Ramón sin consultar con Rodríguez Feo lquizá a sabiendas de que no lo aprobaría, ya que era amigo personal de los atacados) $y$, aunque ni el texto ni las turbulencias que produjo eran para tanto, su publicación provocó la ruptura entre los directores.

De la revolución vanguardista al estallido de la Revolución. Notas sobre poesía y política entre 1930 y 1959

REMEDIOS MATAIX 


\section{0}

"Borrón y cuenta nueva», Ciclón, no 1 (1955). Cito por el texto recogido en Carlos M. Luis «Los pintores de La Habana», en Jacobo Machover (ed.), La Habana (1952-1961). El final de un mundo, el principio de una ilusión, Madrid, Alianza Editorial, 1995 , pág. 171

\section{1}

Véase, por ejemplo, su artículo «Terribilia meditans...», en Poeta, núm. 1 (1942), donde Piñera arremetía ya contra la estética de Lezama en abierta hostilidad.

\section{2}

El término es de Carlos $M$. Luis, en op. cit., pág. 171.

\section{3}

En Iván González Cruz (ed.), Miscelánea. Archivo de José Lezama Lima, Madrid, Centro de Estudios Ramón Areces, 1998, págs. 743-744.

\section{4}

José Rodríguez Feo, "La neutralidad de los escritores», Ciclón, n 1 (1959), págs. 36-37. Cito por el texto recogido en Diccionario de la literatura cubana \{1984) edición digital de la $\mathrm{Bi}$ blioteca Virtual Miguel de Cervantes, 1999

De la revolución vanguardista al estallido de la Revolución. Notas sobre poesia y política entre 1930 y 1959

REMEDIOS MATAIX gida por él y con Virgilio Piñera como secretario y colaborador más activo, que, de acuerdo con su nombre, se proponía arrasar con todo, empezando por Lezama y su grupo. «Borrón y cuenta nueva» se titulaba el texto de presentación, enteramente dedicado al asunto, donde se proclamaba:

Lector, he aquí a Ciclón, la nueva revista. Con él borramos a Orígenes de un golpe. A Orígenes, que como todo el mundo sabe tras diez años de eficaces servicios a la cultura en Cuba, es actualmente sólo peso muerto. Quede pues sentado de entrada que Ciclón borra a Orígenes de un golpe. En cuanto al grupo Orígenes, no hay que repetirlo, hace tiempo que, al igual de [sic] los hijos de Saturno, fue devorado por su propio padre ${ }^{60}$.

Afortunadamente, Orígenes no era sólo la revista, pero a las virtudes del grupo que perduraron hay que añadir, sin duda, la promoción de una nueva expresión poética que orientó a la poesía cubana por caminos opuestos a los que la publicación de Lezama había transitado: aquella República de la Poesía sentó también las bases para su propia disidencia desde que la primera «rebelión» de Virgilio Piñera, todavía en la órbita lezamiana, reaccionara contra una obra que quizá aún admiraba, pero que no era ya la que él quería hacer ${ }^{61}$. Y en su caso era una negación «dialéctica», no generacional.

No parece verosímil que aquel conflicto entre los directores de Orígenes, por grave y hasta justificado que fuera, provocara por sí solo la rencorosa ruptura que se proclamaba ya en el primer editorial de Ciclón y que convirtió a Virgilio Piñera por largos años en "Némesis de los origenistas» ${ }^{62}$. Tal disidencia, y los ataques correspondientes, adquieren, con la perspectiva que da el tiempo, los valores de esa constante cultural de «agotamiento de las formas». Y Piñera, cuya obra pareció vivir siempre adelantada a su tiempo, pudo ser portavoz también de ese pronóstico, pues desde Las furias (1941) o La isla en peso (1943), demostró que su obra obedecía a otro rumor, muy distinto del que inspiraba a Lezama. Con la aparición de Ciclón en 1955 se abría, pues, una tribuna para un autor que nunca cupo en Orígenes y que rompe entonces definitivamente con ella, con su estética, con su ética y con su figura central. Pero esa fue una ruptura anunciada y razonada desde mucho antes. Las reflexiones de Piñera al respecto permiten comprobar que ya en $1944 \mathrm{el}$ autor estaba anunciando, al mismo tiempo, la necesidad de un nuevo lenguaje y el agotamiento del anterior. Como acuse de recibo del primer ejemplar de Orígenes, advirtió a los editores:

...Llega en un momento crítico de nuestras letras: Imposible a la altura a que estamos continuar con las soluciones de hace un lustro y medio; entonces ellas funcionaban; hoy no serían sino peso muerto. Orígenes tiene que superar ese delicuescente marbete de morceaux choisis con que se adornan las culturas cuando, habiendo cumplido su fase dinámica, entran a esa elegante pero estéril postura de la momia. Yo quiero decir concretamente que Orígenes tiene que llenarse de realidad, y lo que es aún más importante y dramático: hacer real nuestra realidad ${ }^{63}$.

La de Ciclón fue, sin duda, una postura más acorde con la inquieta personalidad de Piñera y más acorde también con las nuevas corrientes de pensamiento y expresión que ya empezaban a imponerse y exigían romper con una visión de las cosas que, a la luz de los cambios que se avecinaban, podían ser tachadas de anacrónicas en el nuevo contexto. La vocación de la revista, igual que la de Orígenes, siguió siendo más literaria que política, pero es interesante señalar que su silencio de dos años se explicó a los lectores aduciendo esa segunda motivación: según señala su director cuando reaparece en 1959, Ciclón había suspendido su publicación en junio de 1957 «...porque en los momentos en que se acrecentaba la lucha contra la tiranía de Batista y moría en las calles de La Habana y en los montes de Oriente nuestra juventud más valerosa, nos pareció una falta de pudor ofrecer a nuestros lectores simple 'literatura' ${ }^{64}$.

Los acontecimientos que se habían sucedido vertiginosamente durante aquellos años sin duda ayudaron a Rodríguez Feo a intuir astutamente por dónde irían las cosas. El golpe de estado ya había violentado la legitimidad y legitimado la violencia, pero 1956 significó para el gobierno de Batista el inicio del terrible ciclo de toda dictadura amenazada: la represión oficial que incita al terrorismo, y los actos terroristas que justifican la represión. Ese año trajo también fuertes sacudidas que debilitaron la apariencia de estabilidad que trataba de mantener el gobierno: se con- 
solidaba el Directorio Estudiantil Revolucionario orientando hacia la acción violenta la oposición al régimen; en abril fue descubierta y desarticulada una conspiración contra Batista organizada por militares leales a la Constitución, que provocó largas secuelas de arrestos; y en diciembre, Fidel Castro desembarcó del Gramma en la provincia de Oriente y se internó en las montañas con sus seguidores, perseguido por las Fuerzas Armadas. El gobierno expidió partes oficiales dándolo por muerto, pero sólo dos meses después, en febrero de 1957, el New York Times publicaba su célebre entrevista a Fidel Castro desde Sierra Maestra, cuyas consecuencias inmediatas fueron la popularización de su imagen, que adquirió el monopolio del liderazgo revolucionario, la noticia de que sus guerrillas seguían activas desde los montes de Oriente y la certidumbre de que el panorama político amenazaba turbulencias. Quizá nadie sabía a ciencia cierta lo que esos acontecimientos podían significar, pero debió ser muy difícil sustraerse a la inquietud del ambiente: eran signos inequívocos de que algo estaba pasando y de que ese algo podría convertirse en otro «borrón y cuenta nueva» que esta vez escribiría las páginas de una historia inédita.

Ciclón quiso participar en el proceso y propuso avanzar hacia los nuevos horizontes que se empezaba a avizorar con nuevas formas de sacudimiento cultural, más cercanas a valores «vanguardistas», favorables a la ruptura sin nostalgias, al contacto con las masas y a la renovación del lenguaje poético; algo que chocaba frontalmente con la oscuridad militante de Lezama y las aspiraciones origenistas acerca de hallar una sustancia esencial y resistente frente al tiempo. De hecho Ciclón rompió tanto y tan explícitamente con su antecedente que más bien se subordinó a él por negación. Publicar en la revista de Piñera era ya en buena medida estar en contra del proyecto de Lezama, y, si los nuevos poetas vacilaban al em- prender una orientación común antes de 1959 - trascendentalismo origenista o inquietudes existenciales; intimismo neorromántico o «compromiso»; sobreabundancia barroca o sencillez testimonial-65, Ciclón les pudo ayudar a encontrarla: al oponerse al trascendentalismo de Orígenes, la revista estaba defendiendo un interés por lo inmanente, por la realidad, por el día a día, que la Revolución confirmaría como prioritario. Basta recordar que en Ciclón publicó buena parte de la nueva generación de escritores que emprendería muy poco tiempo después la defensa del coloquialismo desde las páginas literarias del periódico Revolución.

Desde este punto de vista, el antiorigenismo de Ciclón tal vez estaba anunciando, no sólo la confrontación que estallaría inmediatamente después entre el grupo Orígenes y algunos portavoces de las primeras urgencias revolucionarias, sino también el nuevo realismo que se impondría de ahí en adelante: Virgilio Piñera fue el único «rescatado» de todo el grupo Orígenes en el nuevo contexto revolucionario, tal vez porque él fue «el único que se aproxima, más que por la tangente, por la secante, al orbe coloquial» ${ }^{66}$, y ya desde las páginas de Ciclón, los poemas que siguieron escribiendo Lezama, Vitier, García Marruz, incluso Diego, se identificaron con esa sensibilidad remota y ese «trasnochado hermetismo», contra cuyo auge se opuso violentamente Lunes de Revolución desde 1959, y se volvería a pronunciar la revista El Caimán Barbudo en 1966, decretando el triunfo definitivo del Coloquialismo.

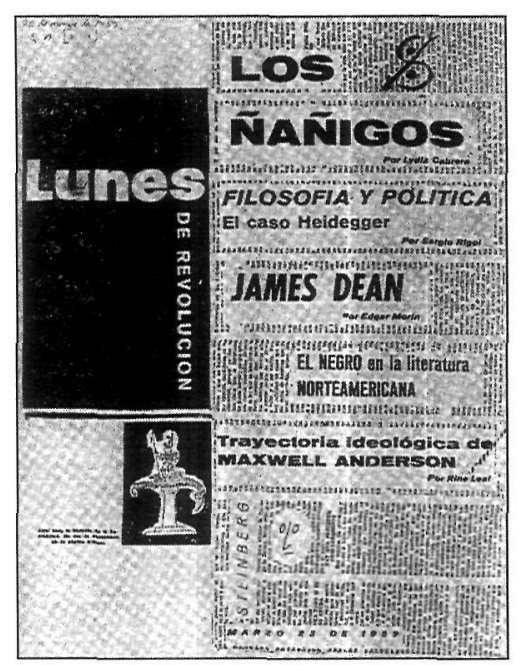

Primera página del primer número de Lunes de Revolución.

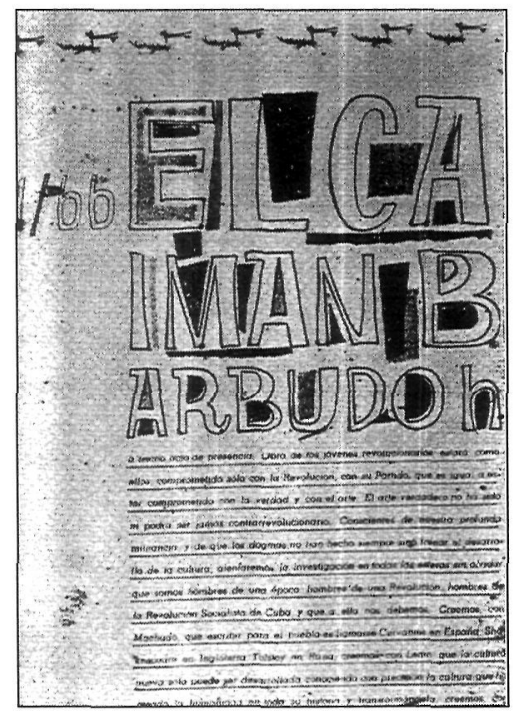

Primer número de El Caimán Barbudo.

65

Véase Teodosio Fernández, «Los poetas de la Revolución», de su Un siglo de poesía cubana, en Susana y los viejos, $n^{\circ} \quad$ 1-2 (1997), págs. 171-175.

66

Virgilio López Lemus, Palabras del trasfondo. Estudios sobre el coloquialismo cubano, La Habana, Letras Cubanas, 1988, pág. 22. 


\title{
LA NARRATIVA CUBANA DEL SIGLO XX NOTAS PARA LA RECONSTRUCCIÓN DE UN PROCESO
}

\author{
TEODOSIO FERNÁNDEZ
}

Oculto tras personalidades como Alejo Carpentier y José Lezama Lima, y enmarañado por las disputas entre los defensores y los adversarios del régimen revolucionario institucionalizado desde 1959, el desarrollo de la narrativa cubana del siglo XX no es fácil de seguir. El período anterior a la revolución ha resultado especialmente perjudicado: casi ignorado permanece un proceso similar al seguido por la narrativa hispanoamericana de esa época, con su herencia modernista y naturalista del novecientos, su acercamiento a la naturaleza, su irrupción de los movimientos de vanguardia, su derivación hacia el compromiso político y, finalmente, su respuesta a las profundas inquietudes existenciales derivadas de la segunda guerra mundial, en todo momento con personalidades y peculiaridades dignas de atención.

El cosmopolitismo de la tradición modernista - y también su interés creciente en la intimidad de los personajes - estuvo representado especialmente, en vida y en obra, por Alfonso Hernández Catá, desde que en 1907 publicó en Madrid la primera edición de sus Cuentos pasionales hasta que su talento «psicológico» (en versión morbosa y fatalista) culminó con los relatos de Manicomio, editado también en Madrid, en 1931. Simultáneamente otros escritores apoyaban en la tradición naturalista - aunque los límites con el modernismo tampoco fueron claros en $\mathrm{Cuba}-$ sus análisis de una realidad republicana necesitada de regeneración. Novelas significativas a este respecto fueron $L a$ honradas (1917) y Las impuras (1919), del médico Miguel Carrión, y Generales y doctores (1920) y Jwan criollo (1927), del extrabajador ferroviario Carlos Loveira. En ellos quedó una visión crítica y desesperanzada de la realidad cubana, desde actitudes de denuncia que acentuarían después autores como José Antonio Ramos, en Coaybay (1926) y Las impurezas de la realidad (1929), y Luis Felipe Rodríguez, el más destacado representante de la narrativa cubana «de la tierra» gracias a la novela $L a$ conjura de la ciénaga (1923, reescrita y publicada de nuevo en 1937 como Ciénaga) y a los cuentos de Marcos Antilla, relatos del cañaveral (1932).

Esa narrativa se hacía eco de la atmósfera cada vez más asfixiante que se respiraba bajo la dictadura de Gerardo Machado, hasta su caída en 1933. Pero la actitud de los intelectuales aún había de radicalizarse después, frente a la presión norteamericana que condicionó la actuación del presidente provisional Carlos Manuel de Céspedes y determinó luego la de Fulgencio Batista, jefe del ejército que entre 1934 y 1940 vigiló la política nacional. En ese clima se acentuó el compromiso de los escritores con la realidad social y política del país, en beneficio de la orientación realista que ya antes parecía dominante entre los narradores cubanos, capaz de conciliar la tradición del naturalismo con inquietudes de signo socialista. Frutos característicos de la época pueden encontrarse en las novelas históricas El negrero. Vida novelada de Pedro Blanco Fernández de Trava (1933), de Lino Novás Calvo, y Caniquí. Trinidad, 1830 (1936), de José Antonio Ramos, o en Hombres sin mujer (1938), donde Carlos Montenegro narró sus implacables experiencias de quince años de cárcel, y en los 
«testimonios» de Pablo de la Torriente Brau -Realengo 18, Presidio Modelo, Aventuras del soldado desconocido cubano-, difundidos después de que muriera en combate durante la guerra civil española. Esa fue la orientación dominante en la época, aunque no impidió que se manifestasen propuestas ajenas a la tradición realista y costumbrista: las novelas «gaseiformes» de Enrique Labrador Ruiz - El laberinto de sí mismo (1933), Cresival (1936) y Anteo (1940) — fueron las más radicales, pero pueden inscribirse en esta otra opción obras como Jardín, la «novela lírica» que Dulce María Loynaz escribió hacia 1935 aunque no se publicase hasta 1951, e incluso como EcueYamba-O (1933), donde Alejo Carpentier, desde Europa, dejó constancia de su interés por los ritos afrocubanos, fascinantes para quien en lo atávico e irracional encontraba manifestaciones de una intuición poética de la realidad. Por entonces ya relacionaba esas formas culturales con la posibilidad de recuperar la armonía de los orígenes, con el acceso a verdades profundas de la naturaleza humana ${ }^{1}$.

Con la segunda guerra mundial la atmósfera política cambió bruscamente. La guerra civil española había colocado a la mayoría de los intelectuales cubanos al lado del bando republicano derrotado, pero los avatares del nuevo conflicto - el pacto entre Hitler y Stalin primero, la alianza de la Unión Soviética con el capitalismo europeo y norteamericano después- sembraron un desconcierto al que no fue ajena la situación interna: Fulgencio Batista accedió a la presidencia en 1940 con el apoyo de un frente popular en que se integraron los comunistas, y entre sus ministros se contaron personalidades tan significativas de la izquierda como Juan Marinello y Carlos Rafael Rodríguez. Con la guerra fría llegaría el fin de esa alianza, y la hostilidad culminaría cuando, tras los gobiernos del Partido Revolucionario Cubano («Auténtico») de Grau San Martín (1944-1948) y Prío Socarrás (19481952), Batista dio un golpe de estado y se instaló en el poder para quedarse hasta que Fidel Castro entrara triunfante en La Habana el 1 de enero de 1959.

Esas dos décadas habían de ser extraordinariamente ricas para la literatura cubana. Eran varios los escritores notables que continuaban en actividad, como Novás Calvo, autor de La luna nona y otros cuentos (1942) y traductor excelente de Hemingway y otros es- critores norteamericanos e ingleses, y Labrador Ruiz, que prolongó su práctica vanguardista con los relatos reunidos en Carne de quimera («novelines neblinosos», 1947) y Trailer de sueños (1949), para adoptar un registro más realista en la novela $L a$ sangre hambrienta (1950) y en los cuentos de El gallo en el espejo (1953). Una orientación costumbrista y crítica se concretó en novelas como Fotuto (1948), de Miguel de Marcos, y cabe resaltar el interés de los relatos que Onelio Jorge Cardoso incluyó en Taita, diga usted cómo (1945) o El cuentero (1958). Además, es en esta época cuando se produce la irrupción decidida de la narrativa cubana en el ámbito literario de Hispanoamérica, irrupción que ha de relacionarse necesariamente con Alejo Carpentier y su descubrimiento de lo real maravilloso americano. Ecue-Yamba $O$ ya había sido una consecuencia de la visión de América Latina como un mundo ajeno a la razón y a la ciencia. En los años veinte esa convicción estaba muy extendida en París, donde Carpentier contó con las propuestas del surrealismo para aderezar los atractivos de su tierra natal. En Haití, en 1943, recibiría la revelación definitiva de la condición maravillosa de aquella realidad, revelación que divulgó en 1948 desde el periódico El Nacional de $\mathrm{Ca}$ racas, y que tuvo extraordinarias consecuencias literarias: las novelas El reino de este mundo (1949) y Los pasos perdidos (1953) serían sus mejores aportaciones personales a la configuración de una de las más persistentes visiones contemporáneas de Latinoamérica, una geografía habitada por mitos ancestrales, escenario de hechos que convertirían su historia en una crónica de lo real maravilloso, ámbito en el que intentar el viaje imposible hacia los orígenes del hombre.

La significación de Carpentier ha sido suficientemente estudiada, y quizá resultó más decisiva para el desarrollo de la novela hispanoamericana en su conjunto que para el de la cubana en particular. Para entender lo que había de ocurrir en la isla quizá conviene recurrir a las diferencias que enfrentaron por entonces a José Lezama Lima y a Virgilio Piñera, a ese conflicto «entre dos estéticas - dos visiones del mundo, en realidad-opuestas e irreconciliables, que en buena parte determi-

ALEJO GARPENTIER

EL REINO

DE ESTE MUNDO

(Relato)

E. D. I. A. P. S. A.

Dion lbero Americana de Publicaciones, S.A. 1949

1 Con esa significación y con el interés de la época por los sectores populares ha de relacionarse la atención a los temas afrocubanos que se concretaría en recopilaciones de cuentos y leyendas como ijOh, mío Yemayá!! (1938), de Rómulo Lachatañeré, Cuentos negros de Cuba (1940), de Lydia Cabrera, y Cuentos y leyendas negras de Cuba (1942), de Ramón Guirao.

La narrativa cubana del Siglo XX Notas para la reconstrucción de un proceso

TEODOSIO FERNÁNDEZ 


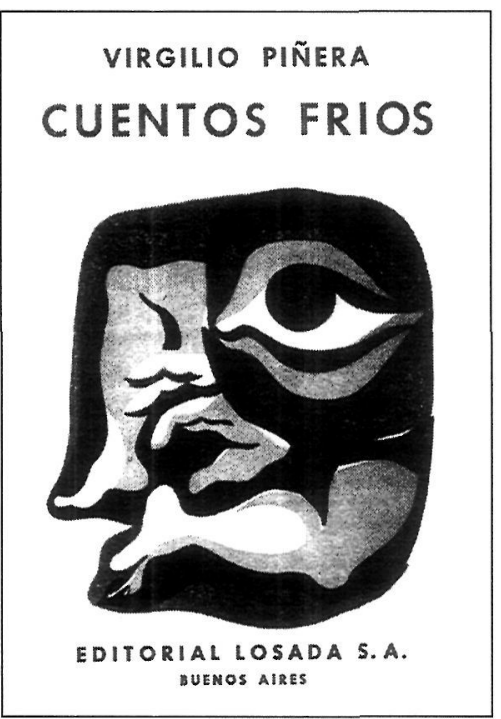

nan algunas tendencias de la literatura cubana hasta nuestros días» ${ }^{2}$. Desde luego, esas diferencias no tuvieron una repercusión inmediata en la narrativa cubana, aunque Piñera ya enriquecía con su novela La carne de René (1952) y con sus Cuentos fríos (1956) la corriente existencialista que toda su obra literaria representaba, una obra insolente, irónica, muy interesada en el absurdo de la existencia, en decidida oposición a Lezama Lima y al grupo «Orígenes». Aunque residió en Buenos Aires de 1946 a 1958, Piñera colaboró activamente en la revista Ciclón (1955-1957 y 1959), que preparó el terreno por

2

Remedios Mataix, La escritura de lo posible. El sistema poético de José Lezama Lima, Universitat de Lleida, Asociación Española de Estudios Literarios Hispanoamericanos, 2000, pág. 96.

3

Mea Cuba, Barcelona, Plaza\&Janés Editores/Cambio 16, 1992, pág. 78.

4

Fidel Castro, Palabras a los intelectuales, La Habana, Ediciones del Consejo Nacional de Cultura, 1961 (Año de la Educación), pág. 11.

La narrativa cubana del Siglo XX Notas para la reconstrucción de un proceso

TEODOSIO FERNÁNDEZ donde, llegado el triunfo de Fidel Castro, había de circular Lunes, el suplemento literario semanal del diario Revolución. De hecho $\mathrm{C}_{i}$ clón ya se había publicado en un clima de agitación, signado por los sucesos de 1956: en abril se desarticuló una conspiración militar contra Batista y en diciembre Fidel Castro desembarcó del Gramma en la provincia de Oriente, iniciando la lucha revolucionaria.

Ciclón tuvo oportunidad de coincidir en 1959 con Lunes de Revolución, que empezó a salir en marzo con la pretensión de llevar el entusiasmo revolucionario al ámbito de la cultura. Guillermo Cabrera Infante, director del suplemento, recordaría mucho después aquel «huracán» que arrasó con muchos escritores del momento: «Teníamos el credo surrealista por catecismo y en cuanto estética, al trotskismo, mezclados, con malas metáforas o como cóctel embriagador» ${ }^{3}$. Esa nueva conjunción de surrealismo y trotskismo, que recuerda confluencias pasadas - en especial el encuentro de André Breton con León Trotsky en México, en 1938, y la participación de ambos en la redacción del manifiesto «Por un arte revolucionario independiente»-, conciliaba el espíritu de Ciclón con el entusiasmo revolucionario que exigía la época; respondía a la voluntad declarada de llevar el arte a la vida, de aproximarlo al medio político, social y económico en que surgía, y de aprovechar sistemas de acercamiento a la realidad como la dialéctica materialista, el psicoanálisis y el existencialismo. La fusión de la vanguardia artística con la vanguardia social y política parecía posible a los colaboradores de Lunes que asumían las obligaciones del intelectual revo- lucionario, implicado en un proceso histórico-social orientado hacia la construcción del socialismo. Virgilio Piñera se encontraba entre ellos, y en ese clima pudo convertirse en la referencia preferida por los escritores más jóvenes, los mismos que creían necesaria la descalificación de Lezama Lima, a pesar de su actitud receptiva e incluso entusiasta hacia los cambios políticos acaecidos.

Pero la identificación de Lunes con la revolución pronto quedó en entredicho. El fin de la publicación se puede relacionar con la protesta de sus colaboradores contra el secuestro de P.M., un reportaje cinematográfico dirigido por Sabá Cabrera y condenado por contrarrevolucionario. El asunto motivó las reuniones celebradas en la Biblioteca Nacional en junio de 1961, y que dieron pie para que Fidel Castro pronunciara sus famosas «palabras a los intelectuales»: «¿Cuáles son los derechos de los escritores y de los artistas revolucionarios o no revolucionarios? Dentro de la Revolución, todo; contra la Revolución ningún derecho», advirtió ${ }^{4}$. En noviembre Lunes dejó de salir. Por entonces sufrió Piñera las consecuencias de las primeras medidas represivas contra los homosexuales, y Severo Sarduy, ligado a Ciclón y colaborador asiduo de Lunes, decidió no regresar a la isla cuando en diciembre de ese año finalizó el tiempo por el que había sido enviado a París para estudiar crítica de arte, becado por el gobierno cubano. El «período romántico» de la revolución había concluido, aunque durante algún tiempo la discusión todavía fue posible y los narradores pudieron elegir las opciones que consideraron más convenientes, incluido Piñera, que aún publicaría las novelas Pequeñas maniobras (1963) y Presiones y diamantes (1967). La primera apareció en Ediciones R (de Revolución), desde donde se habían difundido obras de los escritores ligados a Lunes - como Así en la paz como en la guerra (1960), donde Cabrera Infante reunió sus primeros relatos- y donde pudieron seguir publicando hasta 1964. También hasta esa fecha encontraron acogida en la revista Casa de las Américas, dirigida por Haydée Santamaría. Las dificultades se acentuaron después, con las consecuencias conocidas: Cabrera Infante, agregado cultural en Bruselas desde 1962 hasta 1965, optó por el exilio en octubre de ese último año, y no tardaría en seguirlo Calvert Casey, colaborador de Lunes y de Casa de las Américas, autor de 
los cuentos de El regreso publicados por Ediciones $\mathrm{R}$ en 1962. Luego llegarían los problemas para Heberto Padilla, que también había colaborado activamente en Lunes desde Londres, donde era corresponsal de la agencia Prensa Latina, y que provocó el fin de la primera época de la revista El Caimán Barbudo - había iniciado su andadura en 1966, y hubo de cambiar de dirección y de rumbo a principios de 1968- al publicar sus críticas a Pasión de Urbino, de Lisandro Otero, y sus elogios a Tres tristes tigres, de Cabrera Infante, novelas editadas en 1967.

Con la perspectiva de los años transcurridos, puede advertirse que la narrativa cubana se vio obligada a elegir entre dos opciones fundamentales: la que representaron Virgilio Piñera y los escritores surgidos en torno a Ciclón y Lunes - y que terminaría comprometiendo a Jesús Díaz y otros «caimanes» que habían utilizado el cuento para dar cuenta de sus inquietudes juveniles - y la que consiguió ajustarse a los planteamientos culturales del régimen castrista. Lezama Lima quedó en un territorio propio, desde luego más expuesto a los ataques de Lunes y su círculo que a los de la línea oficial, integrado como estuvo en los organismos culturales creados por la revolución. Pudo observar con preocupación las trabas que obstaculizaron la difusión de su novela Paradiso (1966), culpable de desviaciones sexuales e inquietudes o tentaciones metafísicas, pero nadie resultaría más molesto para él que Heberto Padilla, quien en 1959, desde las páginas de Lunes, lo acusó de mantenerse ajeno a los cambios que se operaban en el país - eso no impidió que Lezama colaborase reiteradamente en el semanario-, y en abril de 1971, en la confesión con que culminó su célebre «caso», lo hizo responsable de opiniones negativas sobre la revolución ${ }^{5}$. En consecuencia, Paradiso supuso una presencia insólita e incómoda en el panorama de la narrativa cubana de los años sesenta, inmersa en un proceso que generaba disidencias sucesivas: la siguiente digna de mención iba a ser la de Reinaldo Arenas, acogido en La Habana por Virgilio Piñera, distinguido por Celestino antes del alba con una Mención Especial del Premio Cirilo Villaverde de la UNEAC, que editó esa novela en 1967, y condenado al exilio interior desde que publicara en México El mundo alucinante (1969).
Las narraciones de Piñera, Sarduy, Cabrera Infante o Arenas son tan personales que difícilmente puede encontrarse en ellas un denominador común. Deben, sí, relacionarse con la orientación surrealizante de Ciclón, convertida al «trotskismo» de Lunes por la necesidad de adaptarse a las exigencias de la revolución y favorecida por la pretensión oficial de atraer hacia Cuba a la izquierda intelectual del mundo entero, pero que siempre mantuvo un carácter vanguardista e independiente, propicio al desarrollo de experiencias tan originales como las que se concretaron en las obras de esos autores. Desde la perspectiva oficial quedaría pronto al descubierto la debilidad de sus fundamentos ideológicos, más evidente en la medida en que el régimen precisaba e imponía su política cultural frente a las algaradas vanguardistas y las inquietudes existenciales. $\mathrm{Al}$ principio se trató de potenciar opciones literarias acordes con la democratización o popularización de la cultura pretendida por las campañas de alfabetización y educación impulsadas por el gobierno, con lo que las experiencias de vanguardia quedaban relegadas al ámbito de los valores burgueses que se quería desterrar. La preferencia por el realismo «socialista» sería consecuente con el proceso seguido por el régimen castrista. $\mathrm{Al}$ explicar esa elección conviene tener en cuenta la evolución de las relaciones de Fidel Castro con los comunistas cubanos, que no habían sido buenas en tiempos de Batista. En 1961 éstos habían confluido con los revolucionarios del Movimiento 26 de Julio en el Partido Unido de la Revolución Socialista, y empezaron a ocupar cargos importantes en el gobierno. En 1965 el propio Castro asumía la dirección del recién creado Partido Comunista de Cuba, que celebró entonces su Primer Congreso.

La sucesión de disidencias o deserciones no impidió que en la isla se desarrollase una narrativa de la revolución con características peculiares, atenta a los avatares de la política cultural del castrismo. Su punto de partida es difícil de precisar, pues las preocupaciones de la mayoría de las novelas publicadas durante los primeros años del régimen revolucionario pueden interpretarse como pervivencia de la novela de la tierra o de la narrativa costum-
5

Véase Remedios Mataix, «Del anatema al diálogo. Lezama y la Revolución», en op. cit., págs. 183-218.

La narrativa cubana del Siglo XX Notas para la reconstrucción de un proceso

TEODOSIO FERNÁNDEZ 


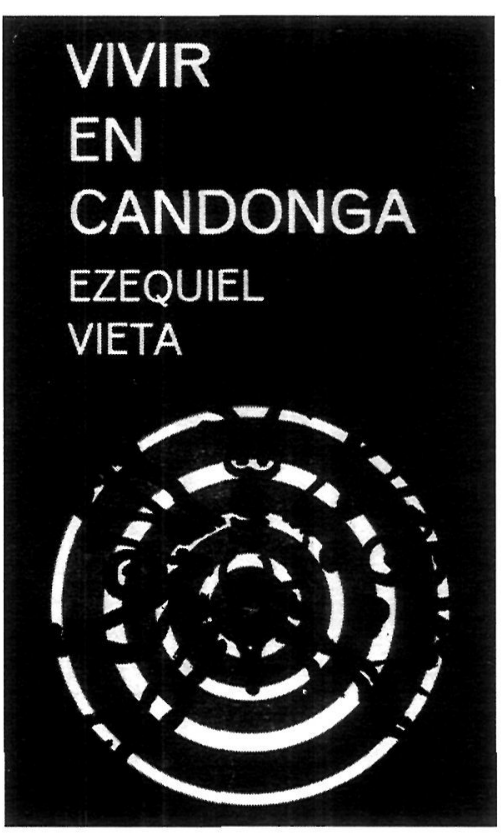

6

Rogelio Rodríguez Coronel, La novela de la revolución cubana La Habana, Editorial Letras Cubanas, 1986, pág. 71 .

\section{7}

Véase Rodríguez Coronel, op cit., págs. 81 y 104.

8

José Antonio Portuondo, «Una novela revolucionaria», en Casa de las Américas, núm. 71, marzo-abril de 1972, págs. 105 106 (106).

\footnotetext{
La narrativa cubana del Siglo XX Notas para la reconstrucción de un proceso
}

TEODOSIO FERNÁNDEZ brista de crítica social. Bertillón 166 (1960), de José Soler Puig, fue quizá el primer resultado significativo e inequívoco de la nueva época, dentro de un panorama ciertamente dominado por la novela existencial, «de clara raigambre sartreana» ${ }^{6}$, lo que por entonces concordaba con la atmósfera cultural cubana: Jean-Paul Sartre visitó la isla en 1960, y Lunes de Revolución celebró su presencia con entusiasmo. Soler Puig recreaba la lucha contra Batista desarrollada en Santiago de Cuba, donde la actividad revolucionaria había tenido su centro desde el asalto al Cuartel Moncada, en 1953. La atmósfera asfixiante de la dictadura se veía afectada por la seguridad de su próximo fin, con lo que los conflictos característicos de la novela existencial - los del hombre alienado y sus posibilidades de desalienación- empezaban a ser reemplazados por otros que enfrentaban la opresión del gobierno de Batista a la liberación revolucionaria. En esa línea, la narrativa cubana de la revolución supo plantear otros conflictos ${ }^{7}$, como el que a la ignorancia y a la pobreza opuso las civilizadoras conquistas revolucionarias en Memorias del subdesarrollo (1965), de Edmundo Desnoes, o el que en Vivir en Candonga (1966), de Ezequiel Vieta, enfrentó el espacio de la ilusión o del mito, el refugio construido por quienes pretendieron vivir al margen del proceso cubano, con la historia que terminaría por arrollarlos.

Ninguna de estas opciones se atenía al discurso antirracionalista dominante en la narrativa hispanoamericana del boom de los años sesenta. Más bien trataban de construir una historia propia, superando las limitaciones sociales, políticas y culturales de la época prerrevolucionaria, y desde esa perspectiva carecían de significación los valores que la literatura de inquietudes existenciales había asignado a la naturaleza y al mito: dejaron de constituir una salida para el alienado habitante de los núcleos urbanos, pues, además de que la lucha revolucionaria se desarrolló tanto en el campo como en la ciudad y el nacimiento del hombre nuevo había de potenciarse en todos los medios, tendió a verse el mundo campesino como un ámbito retardatario, reacio a aceptar los cambios procurados por la revolución. A este respecto había de resultar especialmente significativa La última mujer y el próximo combate (1971), donde Manuel Cofiño López mostró los esfuerzos y dificultades para aplicar el plan de desarrollo forestal y agrario en un medio rural lastrado no sólo por intereses económicos reaccionarios, sino por las creencias y mitos que conforman una visión precientífica de la realidad. Al reseñar esa novela, José Antonio Portuondo vio en ese plan de desarrollo «el polo opuesto de Macondo», y señaló que «lo mágico, lo 'real maravilloso' es aquí la visión caduca y pintoresca, mítica que va quedando atrás, sobrepasada sin violencia por la nueva conciencia socialista, científica, revolucionaria» ${ }^{8}$. Aunque Cofiño estuviera más acertado al mostrar ese mundo en desaparición que al presentar a sus héroes revolucionarios, es indudable que proponía abandonar el discurso narrativo de lo real maravilloso o del realismo mágico y sustituirlo por otra orientación realista y asequible, ajena a la alegorización o mitificación de la realidad hispanoamericana que Alejo Carpentier y Gabriel García Márquez habían ofrecido.

Así parecía imponerse un realismo socialista que trató de mantenerse ajeno a los dogmatismos que en otros tiempos y latitudes habían esterilizado la producción literaria. Lo hizo también a costa de las experiencias formales que se habían hecho frecuentes a mediados de los sesenta, pues la novela de la revolución había procurado aderezar la presentación de sus temas preferidos - los escritores se centraron primero en la crítica de la etapa republicana y en los avatares de la lucha revolucionaria, para interesarse luego por los procesos sociales desencadenados por la revolución y los cambios de mentalidad que exigía-con técnicas narrativas novedosas, las mismas que en otros países latinoamericanos contribuían por entonces a la modernización de la narrativa, y que en Cuba pronto fueron descalificadas como muestra de una nueva dependencia colonial. En el desarrollo de ese proceso resulta significativo el gran predicamento de que gozó el testimonio (reportajes, memorias, diarios de campaña), un género de condición literaria discutible, pero valorado por su fidelidad a las experiencias personales y a la historia reciente. Su variedad más próxima a la ficción fue la novela-testimonio, que obtuvo su primer éxito relevante con Biogra- 
fía de un cimarrón (1966), donde Miguel Barnet reconstruía la vida de Esteban Montejo desde sus tiempos de esclavo hasta el triunfo de la revolución: un siglo de historia cubana, cuya verosimilitud se reforzaba con el respaldo de la formación etnológica del autor.

Esa derivación hacia el realismo socialista estaba en consonancia con la radicalización del régimen, que se acentuó paulatinamente a partir de 1968. Cuando la Casa de las Américas creó un premio para el testimonio -el primero se concedió en 1970 a la uruguaya María Esther Gilio por La guerrilla tupamarala cultura oficial ni siquiera estaba interesada en los trabajos etnológicos o antropológicos que dieran voz a los sectores populares: tras publicar La canción de Rachel (1969), Barnet había iniciado una etapa de silencio que se prolongaría durante más de una década, y el norteamericano Oscar Lewis, patrocinador de la «antropología de la pobreza», se vio obligado a interrumpir en junio de 1970 el trabajo que lo había llevado hasta la isla el año anterior, invitado por el propio gobierno cubano. En esa tesitura, los narradores tuvieron buen cuidado de evitar las tentaciones «metafísicas», sobre todo desde que Fidel Castro, al clausurar el Primer Congreso de Educación y Cultura celebrado en La Habana en abril de 1971 - su lema fue «el arte es un arma de la Revolución»-, dejó claros los límites de lo permitido: «Nuestra valoración es política. No puede haber valor estético sin contenido humano. No puede haber valor estético contra la justicia, contra el bienestar, contra la liberación, contra la felicidad del hombre. ¡No puede haberlo!»9. La narrativa cubana quedaba abocada a sustituir los conflictos existenciales determinados por el impacto de la revolución en las mentalidades prerrevolucionarias por otros relacionados con el presente y con el futuro, en los que el pasado debía contar sobre todo en la medida en que preparaba la revolución.

No es fácil comprobar el impacto de ese proceso fuera de la isla. La revolución cubana sin duda fue un estímulo para que los escritores latinoamericanos saliesen del pesimismo existencialista - las circunstancias históricas de los cincuenta no habían sido alentadoras para los intelectuales de izquierda: los norteamericanos intervinieron en Guatemala para derrocar al presidente Jacobo Arbenz, cayó el peronismo en Argentina, se descubrieron los crímenes de Stalin-y recuperasen la confianza en la historia. La mayoría entendió que en Cuba se había instaurado un socialismo distinto al representado por la Unión Soviética y por el realismo socialista, y los más fieles no cambiaron de opinión cuando Fidel Castro apoyó la invasión de Checoslovaquia por las tropas del Pacto de Varsovia, ni después con el «caso Padilla»: el período romántico de la revolución nunca concluyó para ellos, de modo que pudieron seguir adentrándose en las dimensiones mágicas o fantásticas de la realidad que el surrealismo había ayudado a descubrir, convencidos de que la literatura podía propiciar el cambio de mentalidad frente a las mentiras oficiales que sostenían en Hispanoamérica un orden social injusto, seguros de que el mito constituía un medio para modificar las estructuras mentales, asociando el antirracionalismo - la herencia surrealista seguía activa- con las transformaciones sociales acarreadas por la revolución. Desde luego, el eco de las exigencias revolucionarias se advierte en la polémica que en 1969 enfrentó al colombiano Óscar Collazos con Julio Cortázar y Mario Vargas Llosa en las páginas uruguayas de $M$ arcba ${ }^{10}$, en la pretensión de Cortázar de intentar con Libro de Manuel su Rayuela política, o en la renuncia explícita al discurso mágico-realista que el peruano $\mathrm{Ma}$ nuel Scorza hizo en La tumba del relámpago, la última novela de su saga «La guerra silenciosa». Esas evidencias, y muchas otras que podrían recordarse, no modifican la impresión de que la narrativa cubana de la revolución siguió un proceso propio, y que ese proceso limitó su interés: ninguna de esas novelas alcanzó el reconocimiento logrado por Paradiso, Tres tristes tigres o El mundo alucinante.

En 1971 se considera iniciado el «quinquenio gris» de la cultura cubana de la revolución. La relación de las novelas publicadas permite comprobar que (salvo 1972, en que no apareció ninguna) esos años no fueron mucho peores que otros anteriores, y a ellos pertenecen obras como Cuando la sangre se parece al fuego (1975), de Cofiño López, El pan dormido (1975) y El caserón (1976), de Soler Puig, y otras de autores también muy conocidos en el medio, como César Leante o Miguel Collazo. En 1974 se editaron asimis-
9

Fidel Castro, "Discurso de clausura», en Casa de las Américas, núms. 65-66, marzo-junio de 1971, págs. 21-33 (28)

10

Véase Óscar Collazos, Julio Cortázar y Mario Vargas Llosa, Literafura en la revolución y revolu ción en la literatura, México, Siglo XXI Editores, 1970.
La narrativa cubana del Siglo XX Notas para la reconstrucción de un proceso

TEODOSIO FERNÁNDEZ 
11

Véase Begoña Huertas, Ensayo de un cambio. La narrativa cubana de los ' 80 (Premio Casa de las América de Ensayo, 1993), La Habana, Casa de las Américas, 1993, págs. 50-51.
La narrativa cubana del Siglo $\mathrm{XX}$ Notas para la reconstrucción de un proceso

TEODOSIO FERNÁNDEZ mo El recurso del método y Concierto barroco, del consagrado Alejo Carpentier, quien, consciente de las dificultades que entrañaba la lectura revolucionaria de sus primeras obras, desde El siglo de las luces (1962) había ensayado una adaptación al medio que culminaría con La consagración de la primavera (1978), la novela que (quizá contra García Márquez) mejor había de responder a su proclamada convicción de que con la revolución cubana habían terminado los tiempos de la soledad y empezaban los de la solidaridad. Por otra parte, la necesidad de encontrar soluciones narrativas de menor riesgo facilitó el desarrollo de una novela policial adaptada al medio, normalmente protagonizada por investigadores positivos que contaban con la colaboración del pueblo para perseguir a delincuentes que eran además contrarrevolucionarios. Otro tanto ocurría con las novelas de espionaje, que normalmente enfrentaron a los servicios de seguridad cubanos con la CIA y los enemigos internos y externos de la revolución.

El quinquenio gris se da por terminado en 1976, cuando desde el recién creado Ministerio de Cultura se empezó a reorientar la política cultural del régimen. Fue también el año de la muerte de Lezama Lima, lo que reclamaría nueva atención sobre su obra, enriquecida en lo referente a la narrativa con la publicación de Oppiano Licario (1977). Con La consagración de la primavera y El arpa y la sombra (1979), Carpentier contribuyó a dar la impresión de que la novela se recuperaba en el país, también con la colaboración de Cintio Vitier, poeta de «Orígenes» que descubría su «modesto ser histórico» en De Peña Pobre. Memoria y novela (1979), y de Antonio Benítez Rojo, que con El mar de las lentejas (1979) se sumaba a la renovación de la novela histórica, por citar algunas obras significativas de los últimos años setenta. Pero la situación sólo se vio verdaderamente abocada a un cambio a partir de 1980, desde que miles de cubanos (entre ellos, Reinaldo Arenas) consiguieron abandonar el país por la embajada peruana y el puerto del Mariel, y quedaron definitivamente en evidencia las limitaciones del régimen castrista. El momento de inflexión para los narradores puede situarse en torno a esa fecha, con las Jornadas de Narrativa Cubana que se celebraron en Santiago de Cuba en 1979, 1980 y 1981. En los años siguientes se repetirían los encuentros y la discusión, también sobre el papel de la crítica, mientras la revolución entraba en un «período de rectificación» que la literatura asumiría también.

La narrativa cubana de los ochenta adquiriría así características nuevas dentro de la isla, derivadas de la apertura que sucedió a los esquemas ideológicos de antaño. Novelas como Un rey en el jardín (1983), de Senel Paz, Las iniciales de la tierra (1987), de Jesús Díaz, u Oficio de ángel (1989), de Miguel Barnet, recurrían a la memoria para recuperar la infancia o la adolescencia desde la madurez del narrador, mientras otras preferían abordar el presente inmediato, como Un tema para el griego (1987), de Jorge Luis Hernández, o Fabriles (1988), de Reinaldo Montero ${ }^{11}$. En alguna ocasión parecieron recuperarse orientaciones latinoamericanas perdidas - como la del realismo mágico y la de lo real maravilloso cifrado en la cultura afrocubana-, y desde luego algunos jóvenes se mostraron interesados en rescatar las opciones de los años sesenta que se habían cultivado en la isla y después habían quedado marginadas: aquéllas que habían preferido la lírica a la épica, y que no habían desdeñado la experimentación de técnicas narrativas y la innovación lingüística. No es que la novela cubana de los ochenta se sintiese especialmente proclive al experimentalismo: la riqueza y complejidad del discurso narrativo era en muchos casos una exigencia de la subjetivización ahora dominante en la ficción, de la preferencia por la reflexión sobre la acción. En realidad, más que retornar a posiciones del pasado, la narrativa cubana de la isla se incorporaba al proceso que la narrativa seguía en otros países de Latinoamérica, impulsado por escritores que habían sufrido la represión y el exilio a causa de dictaduras sangrientas, o simplemente se habían sentido afectados por el desencanto que se extendió por entonces ante el fin de las utopías.

Las peculiaridades del pasado reciente hacían más notoria en Cuba la sustitución de la épica colectiva de la revolución por las perspectivas individuales, del objetivismo realista por un discurso interiorizado e incluso lírico. Aunque sólo tratasen de participar en el proceso revolucionario de rectificación - la condena del castrismo quedaba exclusivamente a cargo de los que habían optado por el exilio-, los narradores cubanos también se mostraron ahora interesados en la recuperación del tiem- 
po perdido desde la experiencia personal, sin maniqueísmos ni juicios de valor. Esa narrativa de la memoria coexistió con la que abordaba el presente desde una perspectiva circunstancial, sin pretensiones abarcadoras, a veces con una visión humorística que había sido ajena a la narrativa de la revolución. Ambas opciones iniciaban así la revisión de los logros alcanzados y de los fracasos sufridos, lo que significaba de hecho tomar posiciones ante el proceso vivido por el país, e incluso adoptar formas diversas de crítica y de autocrítica. De ese modo los escritores daban cuenta de una realidad revolucionaria pero también trivial y a veces dolorosa, tan cotidiana como el amor y la muerte.

Esa orientación había de acentuarse desde que el fin de los regímenes socialistas europeos sumió a Cuba en una crisis económica sin precedentes. Con la década de los noventa sobrevino un «período especial» que significó el aumento de las privaciones y la necesidad de afrontar un futuro cada día menos esperanzador. Mientras el desencanto encontraba justificaciones crecientes, paulatinamente fue perdiendo sentido la oposición entre las ficciones escritas y publicadas dentro de la isla y las que se escribían o al menos se publicaban en el exterior, cada vez más numerosas. Desde entones las estancias de los escritores cubanos en el extranjero no se deben sólo al exilio político o a las misiones diplomáticas, como había ocurrido desde 1959; en los últimos años también se han debido con frecuencia creciente a la búsqueda de posibilidades que no se encuentran en la isla, o a la mera necesidad de sobrevivir. $\mathrm{El}$ interés por Cuba y por la narrativa cubana no ha disminuido en estas circunstancias. A ese interés se debe el éxito cosechado por Marilyn Bobes, Abilio Estévez, Eliseo Alberto, Pedro Juan Gutiérrez y Ronaldo Menéndez, entre otros. Es demasiado pronto para valorar lo que significan en el incesante proceso de la narrativa cubana reciente. 
Profesora Titular de literatura hispanoamericana de la Universidad de Alicante, Directora del Secretariado de Relaciones con América Latina y del Centro Iberoamericano Mario Benedetti de la citada universidad.Ha sido antóloga y editora de obras de Miguel Hernández, entre ellas, de la Obra Completa publicada en Espasa-Calpe. En literatura hispanoamericana destacan sus estudios sobre indigenismo y sobre poesía coloquial (Poética coloquial hispanoamericana), así como numerosos trabajos sobre poesía cubana. Otra línea de su investigación es las relaciones culturales entre Espña y América Latina que se han materializado en su libro $\mathrm{El}$ meridiano intelectual en Hispanoamérica.

\section{POESÍA CUBANA A FINALES DEL XX: 1980-2000}

\author{
CARMEN ALEMANY BAY
}

1

En «La última poesía cubana», en AA.V., La poesía nueva en el mundo hispánico, Madrid, Visor, 1994, p. 152.
Poesía cubana a finales del XX: 1980-2000

CARMEN ALEMANY BAY
Cualquier lector que conozca la trayectoria de la poesía cubana desde la llegada de la Revolución es consciente de que a partir del 60 , en general, ésta sigue unas pautas muy ligadas al proceso revolucionario, y que durante casi dos décadas tuvieron vigencia temas vinculados al compromiso y a la poesía de urgencia. Cierto y lógico es que la poesía va cambiando y adaptándose a los nuevos tiempos, y ese carácter de premura del que hablábamos se va modificando en los escritores emblemáticos de la llamada «Primera Generación de la Revolución» y en las sucesivas promociones. Los compases poéticos vendrán lógicamente marcados por otras generaciones que de manera rápida e incesante se suman a la poesía cubana.

A comienzos de los 70 ocurren una serie de acontecimientos políticos que incidirán de manera directa en la literatura y, claramente, en la poesía. Los primeros años de esta década se abren con el Primer Congreso de Educación y Cultura (1971), desde el que se incita a los poetas a crear una obra más comprometida con la Revolución; esta consigna afectará a algunas de las voces de la «Primera Generación», a muchos de los componentes del grupo que se formó alrededor de la editorial «El Puente», así como al grupo del Caimán Barbudo. El resultado fue, como apunta Teodosio Fernández, que «la exaltación épica de la Revolución y de sus protagonistas determinó la extinción de las actitudes críticas y desacralizadoras que estaban en los orígenes de la poesía conversacional. Estas circunstancias dejaban escasas salidas para las inquietudes renovadoras» 1 .

Desde los organismos culturales se apoyó un tipo de poesía, el llamado «tojosismo» (del término «tojosa», paloma silvestre), que duró prácticamente toda la década y que dejará poca huella en los libros posteriores. De un elevado número de poetas que cultivaron esta modalidad, basada en la exaltación de la naturaleza a través de formas estróficas tradicionales como décimas, sonetos o romances, hoy en día sólo quedan algunos nombres como el de Osvaldo Navarro.

Asimismo, la situación cultural se verá agravada por el procesamiento del escritor Heberto Padilla, lo que implicará que intelectuales cubanos, pero también latinoamericanos y europeos, decidan estar al lado o no de la Revolución.

Un enrarecido ambiente cultural se une a una ingrata situación económica, conformando el llamado Quinquenio Gris (1971-1976), que para muchos se extenderá hasta finales de los 70 .

A pesar de la situación, en poesía seguirán apareciendo nuevos nombres como los propuestos en la antología Punto de partida (1970); los poemas y los poetas que en ella aparecen reseñados fueron escogidos por Raúl Rivero, el benjamín de los «caimanes», y Germán Piniella. Cuatro años más tarde sale a la luz otra antología, Nuevos poetas, de Roberto Díaz Muñoz. Los autores incluidos en ambos volúmenes siguen apostando por la continuidad temática, pero sí empieza a entreverse una voluntad de ir depurando la expresión conversacional, tan presente en la década de los 60; en cualquier caso no puede hablarse aún de una rotunda negativa de los movimientos poéticos aparecidos a partir del 59.

Muchos empezarán a ser los escritores que en la segunda mitad de la década de los 70 op- 
tarán por una poética cercana al hermetismo, con creaciones próximas a las del recién fallecido José Lezama Lima (1976). Al mismo tiempo, otro origenista, Eliseo Diego, estará en el punto de mira de los nuevos autores porque desde sus primeras obras compaginó una poética muy relacionada con el grupo Orígenes con otra que no renunciaba a la expresión abierta y muy cercana al coloquialismo.

Precisamente, la poética coloquial muy cultivada en Cuba a partir de la Revolución puso al alcance de casi todos la comprensión poética, pero pronto acabó parodiándose a sí misma y limitando otros caminos poéticos. Fue el binomio coloquialismo-Revolución el que en ocasiones acabó convirtiendo la poesía en mero instrumento de propaganda oficial. Afortunadamente, algunos poetas, los más grandes, pudieron sobreponerse a los estertores revolucionarios y seguir escribiendo poesía desde la coherencia y, sobre todo, desde la poesía, y no desde la política. Pero tendremos que esperar a los años 80 para que se pueda apreciar un verdadero cambio en la poesía cubana, cambio que se resumiría en los siguientes puntos: la individualización del sujeto del poema - ahora es el nosotros el que se diluye entre los nuevos versos para dar protagonismo al yo-; voluntad de volver a los metros y estrofas tradicionales en contra del casi siempre presente verso libre y, sobre todo, la inclusión de nuevos temas más acordes con una realidad crítica. Diferentes tonos, temas y críticas nacerán de un inevitable desasosiego cultural.

Lógicamente, la situación política y económica de los 80 en Cuba ya no es la misma y los jóvenes que encabezan ahora la renovación lírica no han vivido conscientemente los primeros años de la Revolución, sino que han nacido con ella. A esto habría que sumar un cambio de actitud por parte del gobierno cubano, que se concreta en la labor desarrollada por Hart Dávalos, al frente del Ministerio de Cultura, desde la creación de éste en 1976, y cuya tarea fue principalmente reactivar la dinámica cultural de la isla. Desde este Ministerio se hizo un llamamiento al rigor y un rechazo a la autocomplacencia: los dirigentes culturales criticarán la imposición de normas artísticas por parte de algunos funcionarios y los propios escritores denunciarán el acomodamiento y el exagerado mimetismo presente en los esquemas poéticos.
Asimismo, en los 80 se pondrá en marcha el llamado «periodo de rectificación» que, en lo que compete al mundo de la cultura, se resume en el citado espíritu crítico y una mayor apertura a la renovación. Todo esto cristalizará en numerosos actos entre los que destacaríamos el Forum de la Crítica e Investigación Literarias (1987), organizado por la UNEAC, $\mathrm{y}$ al que acudieron especialistas cubanos y extranjeros. Una ebulliciosa y abierta actividad cultural entrará en contraposición con la rigidez del periodo anterior.

\section{EL ANHELADO CAMBIO POÉ- TICO DE LOS 80}

Para este anhelado cambio poético no hubiese sido necesario que Cuba participase de manera activa en la guerra de Angola, que los cubanos vieran la realidad del puente migratorio de Mariel, que Ronald Reagan endureciese la relación con Cuba, que marines norteamericanos se enfrentasen con trabajadores cubanos, que se hiciese patente la deserción, la corrupción y el narcotráfico entre las personalidades del gobierno; pero el resultado de toda esta amalgama de sucesivos acontecimientos en la isla se encauzaron hacia una tímida apertura y una mayor flexibilidad de la que se aprovecharon los jóvenes poetas.

La transición se hizo evidente ya en los años 70 con la publicación de Las puertas y los pasos (1976) de Luis Lorente y La gente de mi barrio de Reina María Rodríguez ${ }^{2}$. La aparición de estos libros coincide con la muerte del poeta origenista José Lezama Lima; y así como los jóvenes del 27 español rememoraron la figura de Luis de Góngora, los jóvenes poetas cubanos homenajearán la figura de Lezama y empezarán a reivindicar una poesía más esteticista y más hermética, huyendo de la ya desgastada poética coloquial que en esos momentos se escribía en $\mathrm{Cuba}^{3}$.

Desde mi punto de vista, Reina María Rodríguez será una de las voces que más nítidamente contrastarán con la poesía anterior y la que mostrará más capacidad de generar una nueva sensibilidad en la poesía. Su obra, atenta al mundo que la rodea, intenta descubrir el asombro de lo cotidiano en un discurso directo y transparente:
2

Para Teodosio Fernández, «el primero (Las puertas y los pasos), relacionable con el tojosismo, enriquecía de símbolos la tendencia aún decididamente referencial de esa poesía. El segundo, más próximo al coloquialismo, ganaba para la poesía cubana un lirismo inusual que recuperaba la manifestación personal de inquietudes y sentimientos》 («Un siglo de poesía cubana», en Susana y los viejos, 1-2, 1997, p. 176).

3

Alicia Llarena (en «De cuando echaron a rodar sus ojos verdes: para una lectura de la joven poesía cubana», en Poesía cubana de los años 80. Antología, (introducción de Alicia Llarena y Osmar Sánchezl, Madrid, Ediciones La Palma, 1994) apunta sobre el lezamismo en los poetas del 80 que «hay en estos autores un especial 'empeño en la búsqueda de la riqueza cultural', y un consecuente 'mayor número de metáforas', de acuerdo con una aceptación lezamiana del hecho literario. Sin que esto último pueda aplicarse indiscriminadamente a todos los poetas, $y$ $\sin$ que esa suerte de imitación del 'lezamismo' o 'neo-origenismo' quiera decir imitación a ultranza» (p. 25).

Poesía cubana a finales del XX: 1980-2000

CARMEN ALEMANY BAY 

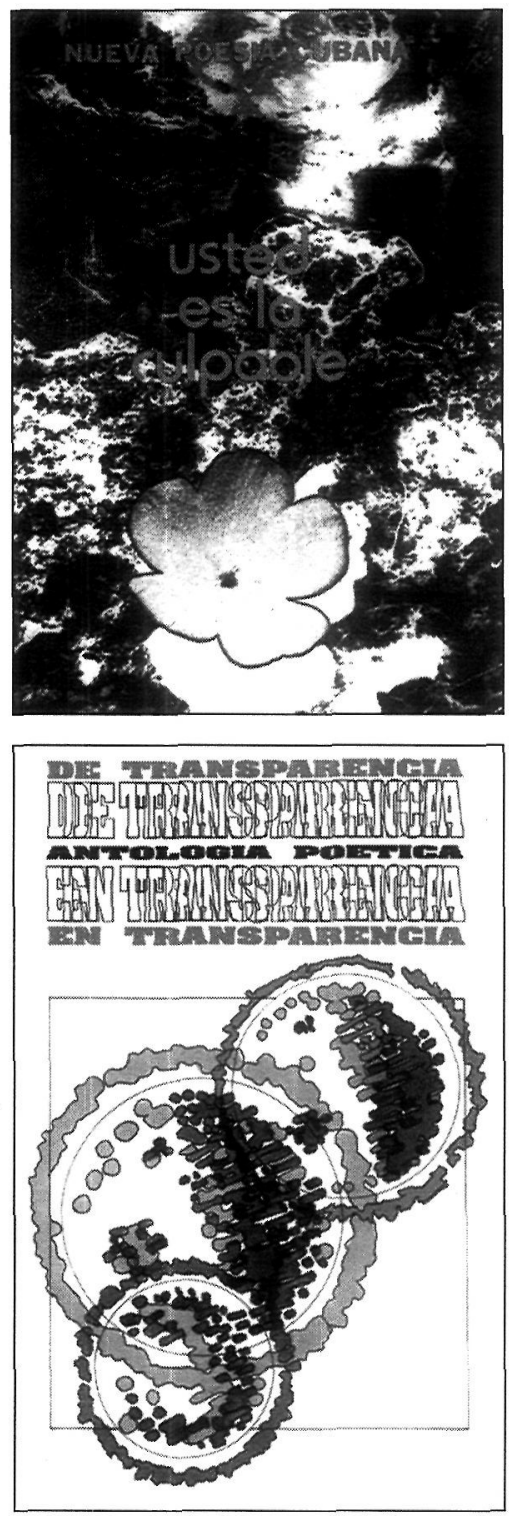

4

Estos versos aparecen antologados en Norberto Codina, Los ríos de la mañana. Poesía cubana de los 80, La Habana, Unión, 1995, p. 74. En adelante, cuando se citen versos incluidos en esta antología, sólo pondré las letras RMy el número de página. Debido a las numerosas antologías que se citan en este trabajo, utilizaré el mismo sistema. Cuando se cite de los poemas de la antología de Teodosio Fernández incluida en Susana y los viejos, op. cit., lo haremos con la letra S; la de Alicia Llarena, op. cit., con las letras PC; Usted es la culpable (La Habana, Abril, 1985) con Ud.; Retrato de grupo (La Habana, Letras Cuba-

Poesía cubana a finales del XX: 1980-2000

CARMEN ALEMANY BAY

llegar a mí. una casa vacía

y ni un solo tesoro.

todo desierto en las esquinas.

cargo con mi casa inmueble desperdicio

el silencio en los túneles

ni siquiera secretos

"Alguna vez. Algún tiempo»4

Por su parte, Luis Lorente enriquecerá el discurso poético mostrando una realidad recogida a retazos: «La vena de su frente y la corbata, renuncian/ a su aspecto de redactar humilde» $(\mathrm{RM}, 60)$, para llevarla hacia otras realidades insospechadas para el lector.

A esos nombres habría que añadir otros cuya obra empezará a tenerse en cuenta a comienzos de los años 80 , la mayoría de los cuales incluidos en Usted es la culpable (1985): Albis Torres, Raúl Hernández Novás, Aramis Quintero, José Pérez Olivares, Soleida Ríos, Abel Díaz Castro, Norberto Codina, Bladimir Zamora, Efraín Rodríguez, Cira Andrés, Alex Fleites, Marilyn Bobes, Víctor Rodríguez Núñez, Ángel Escobar, Roberto Méndez, Osvaldo Sánchez, Ramón Fernández-Larrea y Sigfredo Ariel5. Fuera de la antología pero también representativos de este momento de cambio son los nombres de Emilio de Armas, Alberto Serret, Reinaldo Montero, Abilio Estévez, León de la Hoz o Roberto Méndez, quienes, igualmente, contribuyeron a crear «una poesía mucho me-

nas, 1989) con R y De transparencia en transparencia (La Habana, Letras Cubanas, 1993) con Tr.

5

Antes de la publicación de esta antología aparecerá otra, publicada en México, Cuba: en su lugar la poesía, de 1982, y antologada por Víctor Rodríguez Núñez, en la que ya aparecen muestras de la nueva poesía.

6

Así la ha definido Reina María Rodríguez en una entrevista realizada por Emilio Bejel, Escribir en Cuba. Entrevistas con escritores cubanos: 1979-
1989, Río Piedras, Universidad de Puerto Rico, 1991, p. 349.

\section{7}

El poema de Roberto Fernández Retamar dice así: «Nosotros, los sobrevivientes,/ $\dot{\mathrm{C}} \mathrm{A}$ quiénes debemos la sobrevida?/ ¿Quién se murió por mí en la ergástula,/ Quién recibió la bala mía, / La para mí, en su corazón?/ ¿Sobre qué muerto estoy yo vivo,/ Sus huesos quedando en los míos, / Los ojos que le arrancaron, viendo/ Por la mirada de mi cara/ $Y$ la mano que no es su mano,/ Que no es ya tampoco la mía,/ Escribiendo palabras rotas/ Donde él no está, en la sobrevida?». nos épica y más ética»; una ética que lleva implícita posiciones más reflexivas, menos flemáticas, y más acordes con los nuevos tiempos, como se puede leer en «Identidad» de Marilyn Bobes:

No salgo con pancartas a la calle porque mi tiempo es otro.

Honro a mis muertos con cada sonrisa.

No salgo con pancartas a la calle porque mi tiempo es otro.

Pero tengo 22 años, las manos limpias

y si en algún lugar me necesitan

no tendrán siquiera que llamarme (Ud, 130)

La rebeldía personal irá acompañada de otra de índole poética, como apreciamos en el siguiente poema de Ramón Fernández-Larrea, en el que se parafrasean los primeros versos de «El otro» de Fernández Retamar”:

\section{GENERACIÓN}

Nosotros los sobrevivientes

a nadie debemos la sobrevida

todo rencor estuvo en su lugar

estar en Cuba a las dos de la tarde

es un acto de fe

no conocía mi rostro el frank con su pistola

yo tampoco conozco la cara

de quien va alegremente a joder en mi cama

en mi plato sin la alegría que merece

o que merecería si soy puro

viejo tony guiteras el curita los tantos

que atravesaron una vez la luz

no pensaron que yo sería ramón

sudaron porque sí porque la patria gritaba

porque todas las cosas estaban puestas al descuido

éste es mi tiempo lleno de alambres y beirut

de esa bomba callando

era verdad lo que juanito dijo

la felicidad es una pistola caliente

un esplendor impensado una rosa

todos tenemos alguna estrella en la puerta. $(S, 228)$

La insatisfacción, la amargura, el nihilismo, el individualismo, junto a motivos clásicos de la poesía como el tiempo, la muerte o el amor, serán los temas que la crítica ha insistido en clasificar como topos comunes de la nueva poesía. Antonio Merino, por ejemplo, señala que la nueva poética supone además un "mirarse hacia dentro para 'hurgar' los espacios interiores; la ternura, la inocencia, el juego, la fantasía, los sueños, el mun- 
do infantil, la memoria, la nostalgia, el cariño por las cosas y los objetos familiares»8. Habría que matizar sin embargo que ya «el mundo infantil» o «el cariño por las cosas y los objetos familiares» aparecen también en los versos de la poesía cubana a partir del 59, como señala Virgilio López Lemus en Palabras del trasfondo"; aún más: estos temas han estado presentes en la tradición poética de la isla, como puede comprobarse al revisar composiciones de Dulce María Loynaz, de Eliseo Diego o de Fina García Marruz, por citar algunos nombres. Pero creemos que hay una leve diferencia, y es que mientras esos poetas se sirven de los recuerdos para congraciarse con el presente, los de los 80 los rescatan para conformar una crítica directa al esquematismo ideológico y a lo demagógico.

Los jóvenes poetas ofrecerán un tipo de creación más oscura, críptica y compleja, con muchas referencias culturales; pero el coloquialismo -consciente o inconscientemente- también va a formar parte de su acervo emergiendo en algunos giros, expresiones o citas que no se habían incorporado al lenguaje poético antes del advenimiento del coloquialismo. Así podemos verlo en estos versos de Raúl Hernández Codina de «Quién seré sino el tonto...»:

Sobre la colina está solo and nobody seems to like him, pero él ve el mundo moverse a su alrededor, el sol rebotar como una pelota roja

en el horizonte. El sol tragado por el mar, frío entre los peces. (RM, 37)

Parece un lugar común de la crítica, algo que casi se ha convertido en una tendencia, achacar gran parte de los males de la poesía cubana al coloquialismo; pero no cabe duda de que contra los presupuestos teóricos unos movimientos se levantan otros, pero también lo es que unos asumen otros.

En cualquier caso, el agotamiento del anterior coloquialismo genera en esta década otro tipo de coloquialismo que se centra en un discurso que persigue un efecto narrativo. Lo que sí se ha agotado es la poesía de soflamas revolucionarias, pero no necesariamente esa forma poética que todavía puede dar muchos y valiosos frutos. De hecho, el agotamiento de las formas coloquiales más puramente revolucionarias y programáticas ha desembocado en la dispersión de formas y en la diversidad de voces.
Se podría decir de esta década pero también de la poesía de estos momentos que en ella, como en la de Pound, cabe todo, independientemente de la Revolución, y muy a pesar de ella. Esa libertad poética obtiene como resultado que no exista una escritura dominante sino que los poetas de esta década, y con más fruición los de la siguiente, mezclen el lenguaje sencillo con el altamente poético, y ello con la clara intención de activar contrastes. El resultado es la creación de un lenguaje que ayuda a reflejar la situación cubana actual en la que sin duda también son frecuentes esas diferencias. Pueden servirnos de ejemplo estos versos del poema de Luis Lorente, «Ella canta en La Habana»:

La Habana un paraíso extenso, casi blanco

donde abunda el coral.

Cuando tenga la noche y venga algún deseo,

tú, dios de los cronopios, aléjala de mí. (RM, 57)

Los poetas de los 80 manifiestan sin pudor su necesidad de alejarse del espacio real, de anhelar un nuevo lugar - el suyo-, de sentir que les corresponde elegir su camino; y lo harán, al igual que sus antecesores. En esta senda, el yo predominará sobre el nosotros, como ya apuntamos, $y$ el hecho de que el sujeto sea otro hace que, según León de la Hoz, se replantee «la relación entre obra-autor. Relación confidencial con el lector vs. oralidad en los $60 \gg^{10}$.

La mayor novedad, sin embargo, de la nueva poética está en el mensaje, que es buscadamente crítico, y los poemas se llenan de renuncia a las profecías y a las arengas como veíamos en el poema citado de Fernández Larrea; de ahí que la ironía y el sarcasmo - que habían casi desaparecido del discurso poético cubano desde el inicio de la Revolución-, tengan un lugar preeminente. Ahora el autor no tiene necesariamente que enfrentarse a su realidad, y puede optar por un discurso en el que primen las alegorías, las simbolizaciones, la fantasía, etc.

Quisiera llamar la atención en este punto y señalar la importancia de uno de los tópicos, el de los puentes, que más adeptos tendrá entre los poetas de la década de los 80 y la de los 90; tópico que les sirve de metáfora, de símbolo o de elemento alegórico. El término, que hace referencia a una situación provisoria y también al anhelo de llegar al otro extremo, es lo suficientemente ilustrativo de la situación de Cuba después de más de veinte años de Revolución. El
8

Antonio Merino, Nueva poesía cubana. (1966-1986), Madrid, Orígenes, 1987, p. XXVII.

9

El libro fue publicado en La Habana, Letras Cubanas, 1988. López Lemus hace una clasificación (pp. 96 a la 98) de los temas más frecuentes de la poesía cubana de los 60 .

10

La poesía de las dos orillas: Cuba (1959-1993), Madrid, Libertarias/ Prodhufi, 1994, p. 43.
Poesía cubana a finales del XX: 1980-2000

CARMEN ALEMANY BAY 


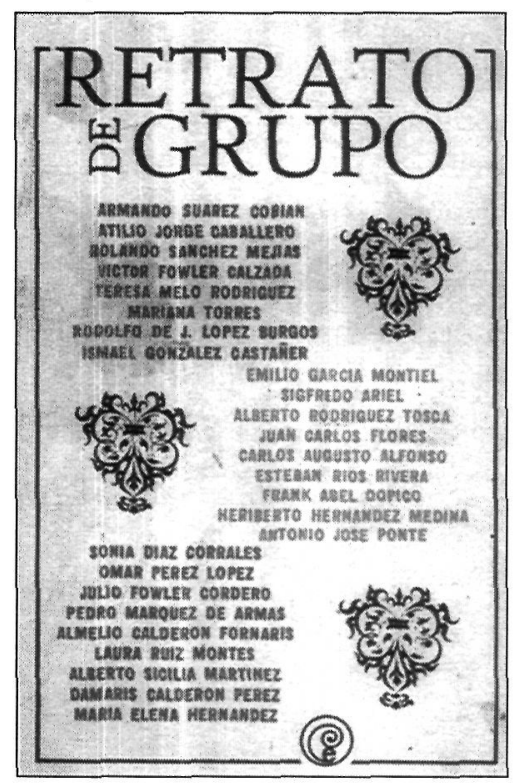

uso de este término refleja una situación real para muchos cubanos como es la situación de estar en medio y a la espera de la conclusión de un proyecto que no llega nunca; un período de transición que no parece tal por su estancamiento. Todo ello provoca en el poeta un sentimiento de decepción y desengaño que tiene su trasvase en la desconfianza del propio lenguaje, en las palabras que está utilizando.

El motivo de los puentes ya lo anticipó Fernández Larrea en su composición «Poema transitorio»:

Es difícil vivir sobre los puentes
Atrás quedó la negra boca el odio
y no aparece el esplendor
esto es también el esplendor
pero tampoco $(\mathrm{Ud}, 176)$

\section{1}

Osmar Sánchez, «Poesía en claro. Cuba, años 80 (long play/ variaciones)", en Alicia Llarena, op. cit., p. 39.

12

Ésta es sólo una muestra de los muchos libros que los poetas de los sesenta publican en los ochenta. Un elenco más extenso lo da Antonio Merino en op. cit., p. XLIII.
Poesía cubana a finales del $\mathrm{XX}$ : 1980-2000

CARMEN ALEMANY BAY y aparecerá en algún poema de Reina María Rodríguez («Cuando se levantan los puentes» (RM, 79)). Le seguirán otras voces como la de Alberto Rodríguez Tosca en «Un puente es un puente en tanto sirve para cruzar al otro lado», pero además «Si estamos de éste, el otro lado es aquel/ si estamos de aquel, etc)»; también la de Heriberto Hernández en «La ciudad de los puentes se suicida, se adormecen el canto de sus muertos», donde reza lo siguiente:

En las escaleras han puesto montones de papeles para evitar que suba,

para evitar que salga a los balcones, el pecho abierto

y la ciudad como un testigo que exige un mínimo discurso,

un pedazo de corazón para lanzar del puente. (RM, 250)

En definitiva, como señala Osmar Sánchez, «En lo que respecta estrictamente al arte y a la vida cultural en general, no podía ser ésta sino una década de redefiniciones, de impugnación de ciertos cánones y modelos hegemónicos; de búsquedas, conquistas y experimentaciones inusuales o ya inusadas en la aún breve historia del arte de este período; de entronque con procesos detenidos en la articulación de los años 60 y 70 ... Como, en efecto, ha sido» ${ }^{11}$.

Sería aún más incompleto este apartado si no hiciéramos mención a la notable producción poética que desarrollan los poetas de los 60 en esta década. Del grupo de los 50, Fernández Retamar publica Juana y otros poemas personales (1980); Pablo Armando Fernández, Campo de amor y de batalla (1984); en el mismo año César López edita Quiebra de la perfección. De los poetas de «El Puente», Miguel Barnet da a conocer su Mapa del tiempo y Nancy Morejón, Piedra pulida (1986); algunos caimaneros como Raúl Rivero saca a la luz Poesía pública (1983) y Guillermo Rodríguez Rivera, En carne propia $(1984)^{12}$. Como era previsible sus poéticas respectivas no han cambiado pero sus versos, adaptándose a los nuevos vientos poéticos, denotan más intimismo y hay menor constancia de lo social: el nosotros de sus poemas ya se avecina más al yo.

Esta década de los 80 ha sido una de las más decisivas en la poesía cubana desde la segunda mitad del siglo XX, no sólo por el cambio de la temática poética sino por la incidencia en los poetas inmediatamente posteriores, porque la poesía sigue en los 90 .

\section{LA POESÍA SIGUE EN LOS 90}

La década de los 90 se abre con una situación histórica y social bastante comprometida que se ve agravada con la caída de los países socialistas y, como consecuencia, los problemas económicos van haciendo mella en la sociedad cubana con la consiguiente depresión en la forma de vida, crisis de valores, etc. La poesía, al igual que en los comienzos de Revolución, no será ajena a los duros acontecimientos cotidianos; pero a diferencia de la década de los 60, los versos seguirán los temas y modos apuntados en los 80 en composiciones de corte reflexivo o antiutópico, sin descartar tonos existencialistas. La carencia de un destino claro en lo cotidiano tendrá su plasmación en lo poético.

Entre las múltiples carencias a las que se enfrentan los cubanos en la vida cotidiana está la falta de papel, lo que incide de manera directa en la publicación de libros. La cantidad de volúmenes que se publicaron en los primeros años de la Revolución contrasta con el número de ejemplares editados en esta década; de manera que una de las soluciones para que los poetas se den a conocer - aparte de los versos escritos en octavillas que pasan de mano en mano- es que sus poemas aparezcan en antologías. En esta línea, Osmar Sánchez señala la irregular situación editorial y apunta que la nueva literatura está emergiendo al 
margen de los libros ${ }^{13}$; y José Luis Arcos afirmará que «este último grupo de poetas ostenta ya el raro privilegio de haber sido el más antologado en toda la historia de la poesía cubana (...) Suelen repetirse los mismos poemas de una antología a otra» ${ }^{14}$. Quizá la más representativa, por su carácter de pionera, sea Retrato de grupo (1989) ${ }^{15}$, y también porque ahí se incluyen las principales voces poéticas de la Cuba de los 90: Armando Suarez Gobian, Atilio Jorge Caballero, Rolando Sánchez Mejías, Víctor Fowler Calzada, Teresa Melo Rodríguez, Mariana Torres, Rodolfo de Jesús López Burgo, Ismael González Castañer, Emilio García Montiel, Sigfredo Ariel, Alberto Rodríguez Tosca, Juan Carlos Flores, Carlos Augusto Alfonso Barroso, Esteban Ríos Rivera, Frank Abel Dopico, Heriberto Hernández Medina, Antonio José Ponte, Sonia Díaz Corrales, Omar Pérez López, Julio Fowler Cordero, Pedro Márquez de Armas, Almelio Calderón Fornaris, Laura Ruiz Montes, Alberto Sicilia Martínez, Damaris Calderón Pérez y María Elena Hernández Caballe$\mathrm{ro}^{16}$. A estos nombres habría que añadir otros, algunos más recientes, como Nelson Simón González, Ronel González Sánchez, Odette Alonso Yodú, José Féliz León, Norge Espinosa Mendoza, Liudmila Quincoses Clavero, León Estrada, Wendy Guerra Torres, Ernesto Ortiz Hernández, Arístides Vega Chapú, Alcides Herrera Duarte, Juan Carlos Valls Hernández, Bárbara Yera León.

Retrato de grupo, como su propio nombre indica, es una muestra de autores - todos ellos bastante jóvenes y, consecuentemente, con poca obra publicada- que, como subrayará Jorge Cabezas Miranda, «se han formado íntegramente dentro del proceso revolucionario. Estos autores comienzan a escribir a partir de los años ochenta, momento en el que se dan una serie de circunstancias convulsas de orden social y político que remueven los cimientos insulares y que van a modificar la realidad de los cubanos ${ }^{17}$.

La antología citada y las que le seguirán nos dan una idea vaga del camino por el que en un futuro próximo seguirán estos autores; pero sí encontramos «el deseo expreso o tácito en la mayoría de estos poetas - como explicita José Luis Arcos- de no escribir poesía conversacional. Esto no implica en ningún modo que en la práctica no utilicen recursos retóricos propios de aquella moda-

lidad poética, ni que renuncien a las ganancias de la oralidad, del habla, de la conversación: conquistas, por lo demás, de la poesía contemporánea y, en el contexto iberoamericano, una calidad y una cualidad poéticas adquiridas ya por nuestro modernismo» ${ }^{18}$. En cualquier caso, los jóvenes buscan desesperadamente una formación individual; y la experiencia personal, el individualismo, y lo cotidiano, también serán perfectamente compatibles con la inclusión de la coloquialidad en el discurso.

A este respecto, es bastante elocuente y descriptiva la opinión de Nidia Fajardo sobre las características formales y temáticas de los autores que componen Retrato de grupo:

Aprovechan todas las posibilidades del juego polisémico para proponer más de una lectura y estimular las capacidades de recepción de cada lector. Esto hace que desechen el sentido directo, inmediato u obvio de los términos, con lo que logran desautomatizar el discurso y, precisamente, la recepción (...) Hay, además, una marcada tendencia a la fabulación, la alegorización y el uso de las parábolas. Lo cotidiano puede estar en estas obras, pero casi siempre asaltado por la magia (...) Desde el punto de vista estilístico, se puede observar una tendencia hacia la densidad metafórica. En muchos casos hay rupturas sintácticas, inconsecuencias predicativas y coordinativas, rupturas de sistema, recursos que aparentemente hacen que se toque el absurdo (...) Trabajan cualquier textura verbal, desde las referencias cultas hasta las «malas palabras», desde los textos en otras lenguas hasta el juego intertextual, los préstamos, las citas (...) La «alta cultura» y el kitsch; la poesía de Lezama, Vitier o Diego y el último texto de un rock (...) dicen de la riqueza y la fuerza de la poesía cubana de hoy ${ }^{19}$.

13

«Poesía en claro. Cuba, años 80 (long play/ variaciones)», en Alicia Llarena, op. cit., pp. 33-79.

14

En «¿Otro mapa del país? Reflexión sobre la nueva poesía cubana", Temas, 3, julio-septiembre, 1995, p. 121.
15

Jorge Luis Arcos, en el artículo citado en la nota anterior, da cuenta de las numerosísimas antologías publicadas a finales de los $80 \mathrm{y}$ comienzos de los 90 , tanto en Cuba como en otros países latinoamericanos o en España. Lo destacable es que en todas ellas se suelen repetir los nombres incluidos en Retrato de grupo.

16

Algunos miembros de este grupo, Carlos Augusto Alfonso Barroso y Omar Pérez, con anterioridad, ya habían dado a conocer lo renovador de su poética. En 1983, Casa de las Américas organizó un recital en el que participaron estos autores $y$ su lectura provocó un gran revuelo por lo novedoso de su mensaje, basado en la denuncia a los aspectos negativos que la Revolución había generado.

17

Novísima poesía cubana. Antología (1980-1998), Salamanca, Ediciones Colegio de España, 1999, p. 22.

18

Op. cit., p. 123.

19

De transparencia en trasparen cia. Antología poética (selección y prólogo de Nidia Fajardo Ledea), pp. 14-15. Por su parte, León de la Hoz (en op. cit., p. 14) divide el periodo poético de la Revolución en tres etapas: «En la primera (1959-1968) tiene lugar el movimiento de los 60 que devela 'lo conversacional', en la segunda (1969-1980) otro movimiento, el de los 70, que agota lo conversacional; y la tercera etapa (1981- hasta la fecha) con un movimiento de los 80 caracterizado por la síntesis, que aún no parece haber llegado a su coda definitiva». Sobre la poesía de los 90, el citado crítico apunta: «Hoy, en los 90 , en la antesala del próximo siglo, los poetas de todas las generaciones no sólo han encontrado un estado de cosas parecido en cuanto a esa supervivencia, en una sociedad urgida de pensarse a sí misma y acudir a la espiritualidad viva en el reservorio cultural de la nación, sino que también hallaron una profunda depresión en la calidad de vida unida al trauma de una de las más promisorias utopías y a la crisis de valores que afecta al mundo, calificada eufimísticamente postmodernista por los teóricos» (p. 43).

Poesía cubana a finales del XX: 1980-2000

CARMEN ALEMANY BAY 

que pasó llorando», El País, Madrid, 2 de agosto de 1998, p. 9.
Poesia cubana a finales del XX: 1980-2000

CARMEN ALEMANY BAY
Por tanto, una poesía que cuestiona las grandes disertaciones y que pone en entredicho la función social de la poesía, aunque ello no implique el olvido de la historia de su país, sino evidenciar los errores derivados de la Revolución: el tabú de la homosexualidad, la doble moral, la hipocresía, etc. Esta variedad de temas llevará consigo la heterogeneidad de los discursos, que es sin duda la principal característica de la poesía última. Una forma de aproximación a esta variedad de lenguajes y de temas es la de examinar algunas de las voces que por su originalidad o por su notoriedad creativa están en la primera línea de la poesía cubana actual.

No es gratuito que empecemos con la poesía de Heriberto Hernández Medina, por ser una de los más significados dentro del hermetismo reinante en la poesía de los 90. La complejidad en sus poemas es en ocasiones algo forzado, pero, cuando no lo es y sabe combinar esas características con lo cotidiano, no podemos sino reconocer su profundo talento:

- Yo amaba la lejanía, su horizonte tan turbio y era dulce la ausencia;

yo, eterna interrogada, fui condenada a amar esta tristeza,

esa muchacha que buscáis

es una música negada al hombre, un arpa que en el sueño

traza arabescos en vuestros pechos de animales felices,

ella es la verdad, vuestra verdad en el espejo «La patria del espejo» $(\mathrm{Tr}, 93)$

La profusión de adjetivos o el uso insistente de la primera persona son dos pilares fundamentales de su creación; como también lo son para Rolando Sánchez Mejías quien, según Arcos, «asume conscientemente, como una voluntad creadora, la diversidad de estilos dentro de su praxis escritural $\gg^{20}$. Y añadirá que tanto Rolando Sánchez Mejías como Omar Pérez López son «los que de una manera más profunda y radical ejemplifiquen la ruptura y la edificación de una nueva norma; ningún poeta de la hornada anterior ha llegado más lejos que ellos» ${ }^{21}$.

A modo de ejemplo puede servirnos el poema "Discursos de los párpados de arena» $(\mathrm{R}, 18)$, de Rolando Sánchez, donde el autor presenta una poética oculta tras una tópica serie de imágenes que se nos presentan en la úl- tima parte del poema («Hoy se nos destinó a decir adiós en andenes/vacíos...»); sin embargo, no se nos escapa la propia reflexión sobre la escritura poética cuando el poeta nos dice: «Claro que esperábamos otra cosa/ a la vuelta de los grandes asuntos» o "No sé de qué más podemos hablar».

Como se apuntaba más arriba, Omar Pérez López comparte con Sánchez Mejías «la ruptura y la edificación de una nueva norma», no en vano éste último es considerado, por estos motivos entre otros, como uno de los autores fundacionales de esta última poética cubana. Su poesía, junto con la de Carlos Augusto Alfonso, introduce «un sello revisionista, de denuncia, pero con aspecto altamente civilizador, sin traumas o violencias» ${ }^{22}$; y así podemos comprobarlo en su composición «Yo ataqué Moncada». Aquí el autor ironiza sobre el tema de la lucha utilizando un recurso muy habitual en la poesía de lucha nacionalista. Carlos Augusto Alfonso dirá: «viejecita llorosa que me ves pasar desde el balcón/ yo sobreviviré a esos fuegos artificiales pues no son/ para mis ojos». Según Mario Vargas Llosa, fue el gran poeta William Batler Yeats quien en su drama patriótico irlandés Catheleen ni Houliban (1902) «inventó aquella imagen de larga reverberación en las mitologías nacionalistas de la vieja que pasó llorando, personificación de la Patria, claro está, humillada y olvidada, esperando a que sus hijos la rediman» ${ }^{23}$.

También el aspecto desmitificador se verá en la poesía de Antonio José Ponte y, específicamente, en el poema «En diciembre viendo volar los fuegos de artificio» ( $R, 115)$ que hace referencia a la fiesta de la Nochevieja. Para el poeta el año no empieza el uno de enero, sino el día de su cumpleaños, y lo demás, no es sino una convención para poner a todos de acuerdo. De este modo, el poeta no cuenta los años, sino sus años: «Un año no comienza en esta noche/ hecha para que algunos abracen y rían, / sino en la calma mañana de mi cumpleaños».

Pero más interesante será la composición «Discurso del día del juicio» (R, 116-118) donde aparecen las palabras «Pisando la dudosa luz del día» (último verso de la estrofa 9 de la Fábula de Polifemo y Galatea de Luis Góngora); éste le servirá para encabezar la composición «Glosa a Luis de Góngora» (PC, 156). Llamamos la atención sobre estos 
poemas porque si bien es frecuente encontrar la cita culta entre los versos de la poesía última cubana (el mismo autor nos la da en otros poemas como «A la manera de Brecht» (PC, 157) o "Confesiones de San Agustín, Libro IX, Capítulo $\mathrm{X}$ » $(\mathrm{PC}, 158)$ donde encontramos a San Agustín y a Santa Mónica como protagonistas del poema), las citas pocas veces hacen referencia a poetas españoles. En cualquier caso, la poesía de este autor «o la de Emilio García Montiel, dables de identificar dentro de un conversacionalismo lírico, resultan dos de las poéticas más características de la nueva norma; o que una poesía como la de Rodríguez Tosca, Alfonso o Frank Abel Dopico - acaso del linaje de la de Fernández Larrea- porten tantos elementos de ruptura ${ }^{24}$.

Desde el «conversacionalismo lírico», García Montiel hará una crítica, en actitud de desafío, a la realidad impuesta por la sociedad revolucionaria, y en esa misma actitud estará Damaris Calderón en poemas como «Ésta será la única mentira en la que siempre creeremos» ( $R, 165)$, en donde se refleja la conciencia de lo inseguro de la comunicación, vinculada al desengaño de los ideales revolucionarios («jugar a ser perfectos» $)^{25}$. La autora, al igual que García Montiel, se atreve a mirar las circunstancias reales que la envuelven, aunque ello no vaya a acarrearle más que desilusión, de modo que pueda llegar a compararse - a diferencia de García Montiel- con un suicida. Esta comparación también la hallamos en el «Autorretrato» de Helena Hernández.

$\mathrm{La}$ insistencia del poeta como loco, o incluso como suicida, es bastante frecuente en la poética cubana de las últimas décadas. A los ejemplos expuestos habría que añadir otros como la composición «Submundo» $(\mathrm{R}, 169)$, de la ya citada Helena Hernández («el loco aguarda bajo el brazo/ su poco de nada»); el verso de Almelio Calderón: «soy un pequeño loco de estación gris», en «Fugacidad» ( $R$, 149); o el de Alberto Sicilia Martínez, «loco cerrando los ojos», en «Huesped» $(\mathrm{R}, 160)$. Pero ya a comienzos de los 80 algunos poetas incidieron en esta misma idea. Raúl Hernández Novás (1948), por ejemplo, habla de «el loco, el tonto que siempre he sido».

En cualquier caso, la soledad y el desengaño de la realidad serán uno de los temas más recurrentes en las voces ya citadas, y en otras como la de Atilio Jorge Caballero y Almelio Calderón Fornaris. Éste último nos describe

espacios de soledad desesperada que contrastan con su preocupación por el mundo; de ahí su voluntad de sumarse a «las nuevas gargantas de los hombres», verso que podría interpretarse también como la voluntad de adherirse a la nueva poesía y liberarse de los moldes anteriores. No en vano, en «Tendré que morder una estrella» manifiesta ese deseo de romper con las ilusiones utópicas y buscar nuevos caminos: se siente defraudado por las esperanzas que le fueron inculcadas en su infancia y recurre a la poesía como canal de expresión para esos sentimientos. Pero la poesía con la que se encuentra no puede satisfacer tampoco su voluntad de comunicación.

En este punto queremos retomar parte de una cita anterior, que «una poesía como la de Rodríguez Tosca, Alfonso o Frank Abel Dopico - acaso del linaje de la de Fernández Larrea- porten tantos elementos de ruptura». Precisamente, Frank Abel Dopico representará otra de las múltiples vías temáticas que aparecen en la actual poesía cubana; él será el poeta del surrealismo, del sueño y de la fantasía, de ahí que sus composiciones nos remitan a estados o situaciones imaginarias, como se ve en «La próxima ciudad», donde el autor pide a gritos construir una ciudad, hacerla mejor o peor pero hacerla él; en el fondo, subyace el deseo de crear su espacio en esa ciudad:

como si estuviéramos locos y contáramos el
aire por parejas
hagamos bien o mal otra ciudad, minúscula.

Sí.

Gato a gato vamos a hacer otra ciudad (PC, 186).

Algunos poetas centrarán su discurso lírico en la utilización de elementos simbólicos como Jorge Yglesias, mientras otros se inclinarán por «discursos de vocación filosófica como el de Lourdes Rensoli; o hasta en esa poética histórica, sustentada en la imagen, de Efraín Rodríguez» ${ }^{26}$.

En definitiva, la última poesía cubana ha dejado paso franco a absolutamente todas las tendencias, incluso a las marginadas y marginales. Así, como marginal, se podría considerar hace unos años la poesía de Norge Espinosa $y$, específicamente, su composición «Vestido de novia» (perteneciente a Breves tribulaciones (1992)), encabezada por unos versos de García Lorca, "Oda a Walt Whitman»,

\section{4}

Jorge Luis Arcos, op. cit., p. 124.

25

Un caso paradigmático de crítica a lo impuesto será el de M. Elena Cruz Valera, autora que por edad pertenecería al grupo de los 80 , pero su discurso tiene plena vigencia en los 90 . De manera personal y poética, Cruz Valera, desde una actitud contrarrevolucionaria, propugnará un cambio social. Encarcelada dos años por difamaciones, $y$ en sucesivas ocasiones en un psiquiátrico por «neurosis nerviosa», promovió la "Carta de los diez», en la que intelectuales cubanos pedian a Fidel Castro cambios inmediatos; también fue la fundadora del grupo «Criterio Alternativo" y fueron numerosas las cartas que envió al mandatario cubano dando su opinión sobre la situación del país, lo que provocó su expulsión de la UNEAC y el repudio público. Su poesía, lógicamente, denunciará el confinamiento, la prohibición y el suyo será un discurso de resistencia frente al poder.

26

Jorge Luis Arcos, op. cit., p. 124.
Poesía cubana a finales del XX: 1980-2000

CARMEN ALEMANY BAY 
Este texto fue incluido en Roberto Fernández Retamar, Ensayo de otro mundo, La Habana, Instituto del Libro, 1967, p. 83.

30

Publicado en Al borde de mi fuego. Poética y poesía hispanoamericana de los sesenta, Alicante, Casa de las Américas/ Universidad de Alicante, 1998, p. 34 . y cuyo contenido - que tuvo gran repercusión en la isla por las atrevidas imágenes homosexuales allí reflejadas- recuerda a los poemas más sensuales del poeta granadino. Lo que fue considerado como antipatriótico, la condición de homosexual, en los primeros años del proceso revolucionario, es ahora un tema descrito sin rubor.

Además de la amalgama de tendencias, la falta de perspectiva temporal complica terriblemente el estudio de esta última década pero, lo que es más importante, enriquece extraordinariamente el tipo de poesía que se hace. Como ha apuntado Arcos: «No es el vacío, la intemperie de valores, su punto de partida, en todo caso son las ruinas, son los ecos, por un lado, de un sistema anterior, y, por otro, sus nuevas preguntas y respuestas ${ }^{27}$. Más explícito será Jorge Cabezas Miranda cuando señala que «la poesía cubana se encuentra en un proceso de búsqueda, tal vez se encuentren los poetas, fieles representantes del sentir cubano actual ${ }^{28}$. Lo cierto es que la poesía cubana en estos momentos se encuentra en un círculo que da vueltas sobre sí mismo sin lograr desligarse de los duros momentos que se viven en la isla. Sírvanos para lo que acabamos de afirmar una cita de Víctor Fowler, quien, en un artículo de título bastante significativo, "Comunicación-comprensión: claridad. Olvidar los sesenta», saca a colación un párrafo que Roberto Fernández Retamar escribió para una antología que nunca llegó a publicarse. Retamar compara los títulos de obras publicadas antes de la Revolución con otras publicadas después del 59. El párrafo decía así:

Bastaría comparar los títulos de aquella generación con los de ésta para verificar ese cambio. De Enemigo rumor (1945), Extrañeza de estar (1946), Las miradas perdidas (1951), Por los extraños pueblos (1958) hemos pasado a Vuelta de la antigua esperanza (1959), Himno a las milicias (1961), Por esta libertad (1962), El justo tiempo bumano (1962), Libro de los béroes (1964). Pero es, desde luego, más que cuestión de títulos. De la oscuridad hemos pasado a la abertura; de la nostalgia a la esperanza; de la extrañeza, a la certidumbre ${ }^{29}$.

Hábilmente, Fowler apostillará:

Podemos hacer ahora lo mismo que entonces y seguir hasta El arte de la fuga (1992), Con el terror del equilibrista (1992), Los altos manicomios (1993), El arte perdido de la conversación (1993), El encanto perdido de la fidelidad (1993), Derivas (1993), Diario del ángel (1994), Páramos (1994), Descencional (1994). Si nos fijamos en los títulos parece el tiempo de olvidar los sesenta ${ }^{30}$.

La poesía sigue. 


\section{AMÉRICA SIII HOMBPE}

\section{BOLETÍN DE SUSCRIPCIÓN}

Nombre

D.N.I.

Dirección

Código Postal y población

Teléfono

Derechos de suscripción: tres números (ordinarios o extraordinarios) de América sin nombre que le serán remitidos por correo a la dirección arriba detallada.

Precio: 3.000 ptas.

Forma de pago:

$\square$ Contra reembolso de cada ejemplar. (1.100 ptas.).

$\square$ Por talón nominativo, dirigido a la Redacción de América sin nombre, Dpto. de Filología Española, Universidad de Alicante. Apartado de Correos 99 - E03080, Alicante (España). 



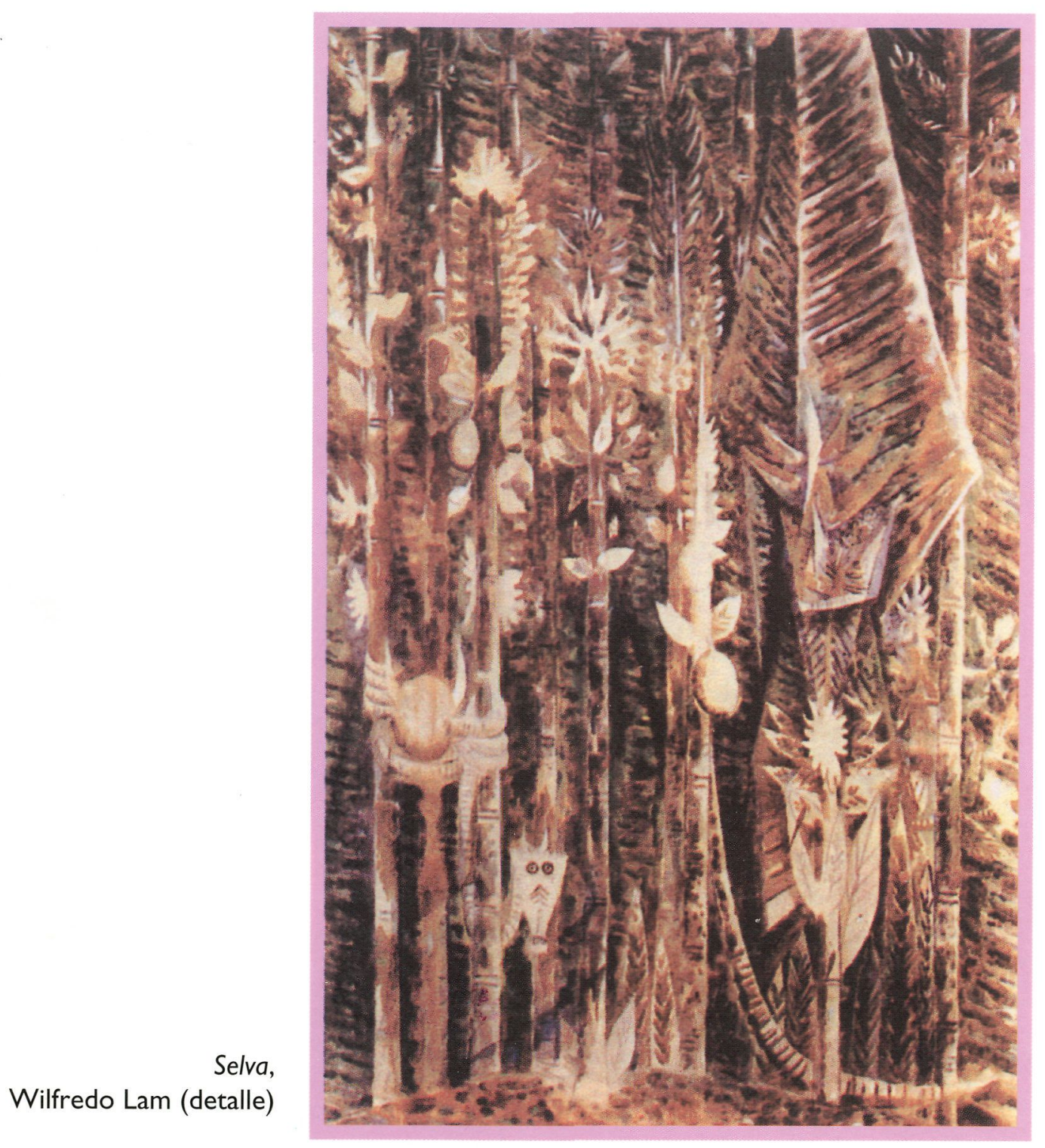

Próximo número (Diciembre 2001): RELACIONES LITERARIAS ENTRE ESPAÑA Y AMÉRICA LATINA coordinado por Carmen Alemany Bay. 